



\title{
THE THIRD PART
}

\author{
OF THE
}

\section{ECCLESIASTICAL HISTORY}

\author{
OF
}

\section{JOHN BISHOP OF EPHESUS.}

NOW FIRST TRANSLATED

FROM THE ORIGINAL SYRIAC

\section{BY}

R. PAYNE SMITH, M.A.

SUB-LIBRARIAN OF THE BODLEIAN LIBRARY.

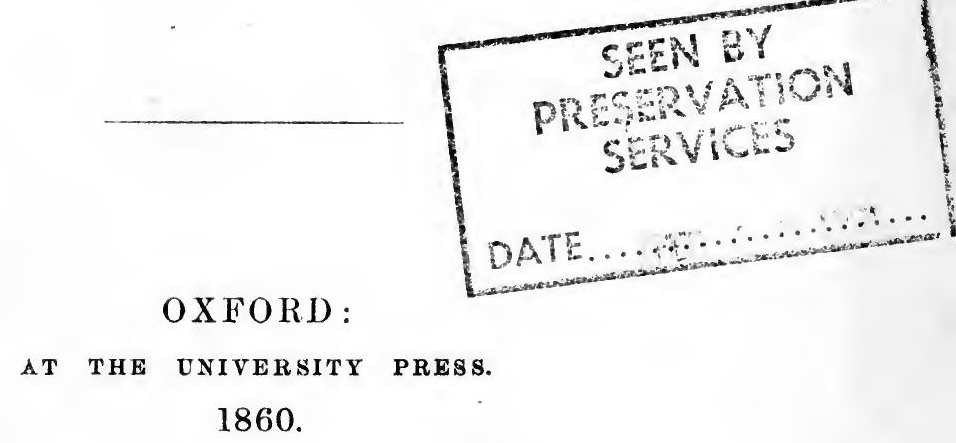




$$
\frac{5805}{111^{\circ}} 6
$$


TO THE

\section{REV. W. CURETON, D. D. \\ CHAPLAIN IN ORDINARY TO THE QUEEN, AND CANON OF WESTMINSTER.}

My dear Dr. Cureton,

You might justly claim this Volume, since it is to you that we owe the splendid edition of the original Syriac. I have the further pleasure of offering it you, as a slight acknowledgment of the assistance I have derived from you in my studies.

Believe me to be,

Yours very truly,

Oxford, Feb. 1860.

R. PAYNE SMITH. 



\section{P R E F A C E.}

THE Ecclesiastical History of John, Bishop of Ephesus, was discovered by Dr. Cureton among the Manuscripts obtained by the British Museum from the convent of St. Mary Deipara, in the desert of Scete, and published in the original Syriac at the Oxford University Press in 1853. It was then his intention, as he mentions in the Preface, to have also undertaken the task of making its contents generally available by means of an English translation; but as more important labours have hitherto prevented the fulfilment of this duty, it has now, with his consent, been undertaken by myself, and I am alone responsible for the correctness with which it has been accomplished.

The chief value of this history will be found in its being contemporaneous with the events which it records; and as the author was resident at Constantinople, and a busy actor in the scenes which he describes, he had the best opportunity of obtaining accurate information : but, on the other hand, it refers to a comparatively late period of the Church, and one to which no special importance has been attached. Still, as a picture of the manners and feelings of .the latter half of the sixth century, it will not be without interest to the ecclesiastical student; especially as the Eastern Church shortly afterwards was brought into collision with Mahometanism, and much new information is given us respecting the Christian Arabs of Ghassan, who 
would naturally be the representatives of Christianity, to their countrymen.

The history, as originally composed, consisted of three parts, of which the first, as our author tells us, commenced with the reign of Julius Cæsar; but as it was probably nothing more than an abridgment of Eusebius, its loss is not much to be regretted. The second part must have contained many interesting particulars of the later emperors, and especially of Justinian, but the extracts from it preserved in the Chronicle of the Jacobite Patriarch, Dionysius, are principally concerned with a record of earthquakes and pestilences. From one or two of them, however, we learn almost the sole facts respecting our author upon which we can depend. The third, of which the present work is a translation, was written under the pressure of great diffculties, owing to the persecution to which John of Ephesus and the sect to which he belonged were exposed, and is consequently of a fragmentary character; for the leaves, he tells us, on which from time to time he inscribed a short narrative of passing events, had to be entrusted to various friends for concealment, and he never found time afterwards to reconstruct his work.

The extracts above referred to, and which will be found in Asseman's Bibl. Or. ii. 83-90, inform us that John of Ephesus was born at Amid, a city in the north of Mesopotamia, probably about A. D. 516; and as Syriac was the language spoken by his countrymen, it was employed by him in writing this history for their use. We subsequently find him at Constantinople, where for thirty years he enjoyed the friendship of the Emperor Justinian, and was employed by him in various important offices. Especially we are informed that he was sent on a mission in A.D. 542 to the heathens in the provinces of Asia, Lydia, Caria, and Phrygia; and so energetically did he labour among them, that in the space of four years he baptized no less than seventy thousand persons. To this mission he also refers 
in the 230th and following pages of the present volume; and from Ephesus, the capital of the district, he took his title of Bishop.

On his return to Constantinople in A. D. 546, the Emperor confided to him the still more serious duty of making search there for such persons as, while professing to be Christians, practised in secret heathen rites : and so many men holding high offices in the state were detected by him, that the Byzantine historians, though they have not preserved his name, yet record the general consternation occasioned by these discoveries. Among the guilty were many even of patrician rank, as well as grammarians, sophists, scholastics, and physicians ; but, above all, Phocas, the prefect of the city, was informed against, and, hopeless of escape, destroyed himself by poison; and his corpse, by the emperor's command, was thrown into a ditch, without the rites of burial. The rest were commanded to assemble in a church, where our author was appointed to instruct them in the doctrines of the Christian religion; and his lessons were enforced by an edict, which, besides other penalties, fixed the period of three months as the limit, beyond which their conversion must not be delayed.

In the present volume we have some further information given us respecting the heathen, and especially an account of some remarkable events which occurred in the reign of Tiberius.

A short notice of our author is also found in Gregory Bar-Hebræus (apud Ass. B. O. ii. 329), who says that ' after S. Anthimus, John was made bishop of the Orthodox at Constantinople :' but this statement must be received with caution. We learn indeed from his description of himself in page 53, that he had the entire administration of their revenues both at Constantinople and the districts adjacent to it, and consequently he must have exercised great influence among his party, and may even have been regarded as their chief. But the whole tenor of his nar- 
rative is inconsistent with the supposition of his being in any sense their patriarch, and if any one can be said to have succeeded S. Anthimus, it was 'Theodosius, the exiled patriarch of Alexandria.

As the name of John is borne by many writers of this period, it has been a subject of inquiry whether some one of them nay not have been identical with our author. But after going over much the same ground as Dr. Land, in his work entitled, 'John of Ephesus, the first Syrian Churchhistorian,' I have come to the same negative conclusion. Should any be sufficiently interested in the subject to wish for the particulars, I cannot do better than refor them to his interesting volume.

For the easier understanding of our author's pages, it may be necessary to add, that he was a Monophysite: and though his party are not to be confounded with the followers of Eutyches, whom they anathematized by name, yet they refused to receive the council of Chalcedon, at which he was condemned, on the ground of its being tainted with Nestorianism. As men's minds were greatly embittered at this period by the disputes which had arisen respecting our Lord's nature, it was found impossible to enforce general obedience in the East to the council's decrees : and thus John's party held a sort of internediate position, not being condemned by their opponents as heretics, and yet being separated from their communion. As they professed themselves ready to obey the teaching of the Fathers generally, and especially, as Renaudot testifies in his History of the Alexandrian Patriarchs (p. 143) 'to accept every thing which John Chrysostome and Cyril had taught,' they claimed as their peculiar right the appellation of 'Orthodox,' and by this name are distinguished in the following pages.

As regards the translation, it seemed scarcely possible, from the fragmentary character of the original, and the frequent loss of leaves, to give merely a verbatim rendering, 
and I have therefore endeavoured to connect the various facts by inserting a few lines here and there, so as to carry the reader over the breaks in the narrative, and occasion. ally I have brought together scattered chapters relating to the same event. In all cases I have marked where the author's own words begin, by placing the reference to book and chapter in the margin : but in comparing the translation with the original, it must be kept in mind, that if the heading was more full than the opening words of the chapter, I have inserted the additional matter. These headings, which occur twice in the original, occasionally with some slight discrepancies, I have confined to the commencement of the volume. As the style of our author is heavy and cumbrous, I have also frequently been compelled to break up his sentences into periods of moderate length, and also to retrench many synonymous words, and even sentences; but in so doing, I have been eareful to omit nothing which had not been said before. In a book, abounding in words not to be found in any lexicon, and which requires almost as great a knowledge of the Greek of the Byzantine historians as of the language in which it is written, errors and mistakes may naturally be expected, and will readily be excused : but I have done my best to give the exact sense of the author, as far as possible, in his own words, and yet in such a form as to prevent the perusal of him occasioning unnecessary weariness to the reader.

OxFond, March, r860. 
[xxiii. For the convenience 
For the convenience of those who may wish to read the original Syriac, I append a Table, 1. of Errata, and 2. of Emendations.

\section{ERRATA.}

P. 11. 1. 17, for . .

P. 12. 1. 2, for durkhỵs read dureras.

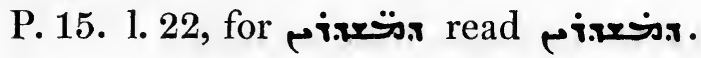

P. 27. 1. 19, for Ritio read Ridr.

P. 30. 1.15. for Räaxis read ragasis.

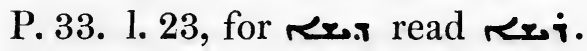

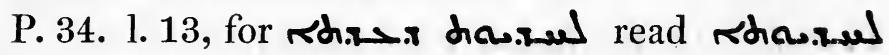
r. ה.

P. 38. 1.24, for amano and read and . a.9ara.

P. 55. 1.11, for read مجدمت

P. 58. 1.5, for Kressh read Resish.

P. 87. 1. 21, for ase read wọ.

P. 101. 1. 16, for pendir read purodir.

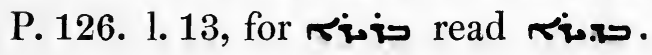

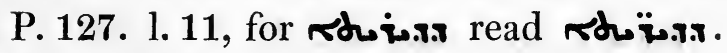

P. 133. 1.5, for durito read doritito.

P.139. 1.13, for kexoi read rotai.

P. 183. 1.24, for Rla read «a.

P. 212. 1.20, for محدبلم read محلدم 
P. 214. 1. 24, after ol insert w.

P. 239. 1.16, for encito read cesido.

P. 240. 1. 15, for Rhit

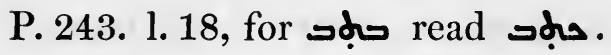

P. 257. 1. 15, for «कs read «mi.

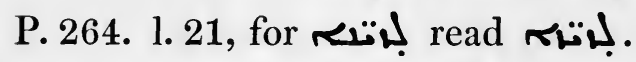

P. 268. 1.2, for Kerino read Ruino.

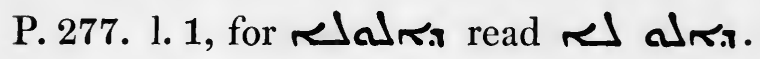

P. 279. 1.8, for pwidios read swidios.

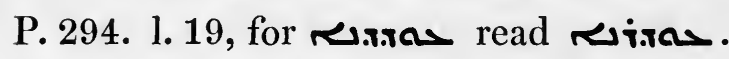

P. 303. 1. 14, for بجم read بهم

P. 310. 1. 24, for rir read ra.

P. 326. 1. 22, for Risrrdiresi read risrodirs.

P. 350. 1.15, for idy read תדبdr.

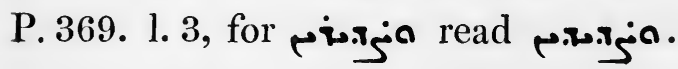

\section{EMENDATIONS.}

P. 3. 1. 18, for *i. read yiغ.x.

P. 3. 1.19, for ***a. read ๔a.rs.

P. 5. 1. 2, for soi read so.s.

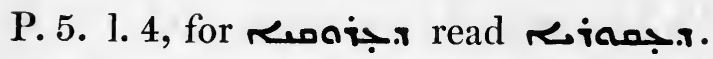

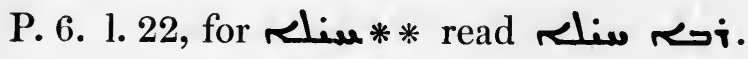

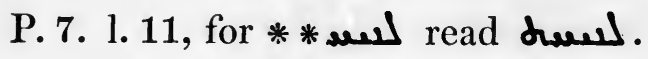

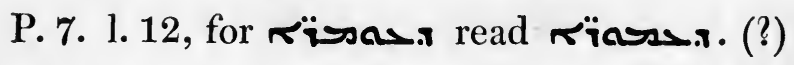

P. 14. 1.1, for risẹl for rriogl.

P. 42. 1.4, for Nodres the margin reads alsders qur. 
P.57. 1. 11, for of

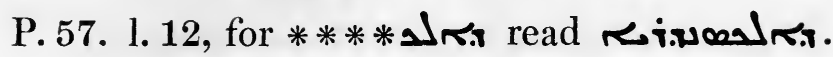

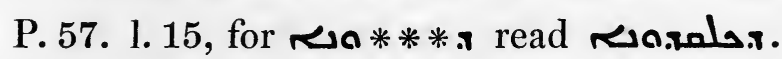

P. 73. 1.7, for dupano the margin reads doesan.

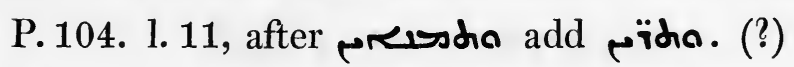

P. 116. 1.11, for quadis read ardirs.

P. 159. 1.12, for Кi甘 the margin has אüdi.

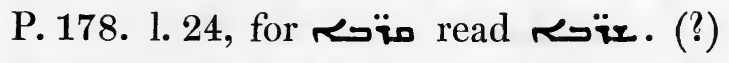

P. 210. 1. 21, for rufoo read rulfon.

P. 213. 1.18, for ro the margin has asa.

P. 246. 1.21, the margin explains that rọ is a nominal verb derived from rstaws.

P. 264. 1. 23, for مبنdidis the margin has م.דdus.

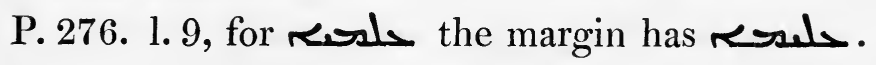

P. 316. 1.17, for asdrera read asdx r.

P. 321. 1. 10, for rكת read The MS. is here indistinct, but probably $=$ is its reading. P.330. 1.23, the margin explains smoinoorsts by mdorios.

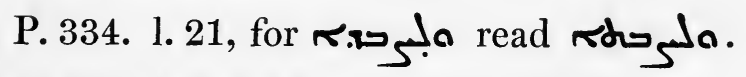

P. 343. 1. 8, for حمب read probably حiم

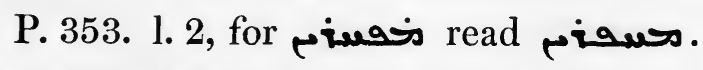

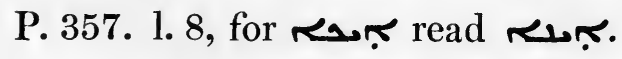

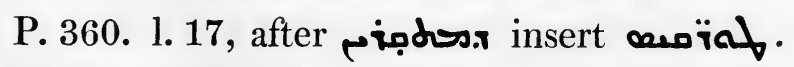

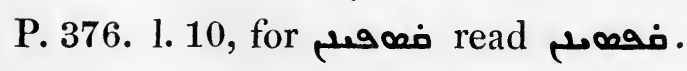


P. 405. 1.9, for Kiffifon read Rufor.

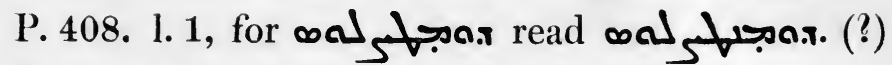

P. 409. 1.10, for rods read sals.

\section{IN THE TRANSLATION.}

P. 148. 1. 15, for ii. 48. read ii. 51 .

P. 160. 1. 16, read: The next chapter (ii. 45.) treated of the Condobaudites, and will be found in page 65 : and the next (ii. 46.) of the apostasy of the Cappadocian monks.

P. 170. 1.12, for mitre read orarium: which was a sort of tippet worn over the shoulders by priests and deacons when officiating at the communion, and by bishops at all times. See Du

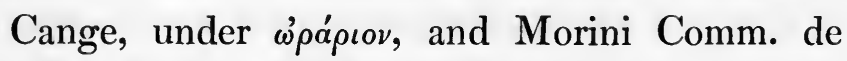
Sacris Ecclesiæ Ordin. p.174.

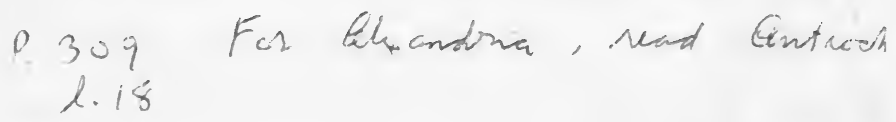




\section{ECCLESIASTICAL HISTORY}

OF

JOHN BISHOP OF EPHESUS.

\section{TABLE OF CONTENTS.}

BOOK THE FIRST.

Chapters I, 2, 3, are lost.

Ch.4. Quotations from the books of the prophets relating to the distress which at this time happened in the $\begin{array}{llllllllll}\text { church of God } & \ldots & \ldots & \ldots & \ldots & \ldots & \ldots & \ldots & 3\end{array}$

5. Upon the bitter suffering caused by the sudden uprooting (lege 1 ;ecs!) of all the congregations of the church of the believers in the capital $\ldots$. . 4

$6,7,8,9$, are lost.

I O. Upon what was done in the convents of men and women by the barbarous violence of the persecution. 6

I I. Concerning John the bishop of the city, and the deeds wrought by the urgency of his wickedness .. $\quad \ldots \quad 8$

12. Upon the priesthood of the Orthodox, which John annulled, without purpose, or respect to justice, and in violation of the canons, and ordained them anew in the priesthood of the Synodites, that is, of those who believe in two natures .. $\quad . . \quad \ldots \quad \ldots \quad$ II

I3. Upon a night vision, which happened to a worthy monk as a revelation of what was quickly about ac-

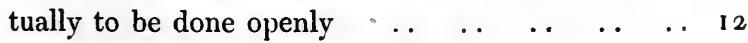

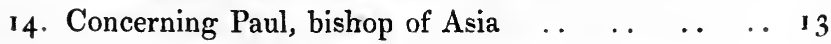


15. Concerning bishop Elisha

16. Concerning bishop Stephan, whom John similarly wished to depose and consecrate afresh

17. Upon their sending for and summoning the bishops from the monasteries and places in which they were imprisoned ..

18. Upon the rebuke and admonition which John received from the bishops whom he had brought together and imprisoned, because of his annulling their laying on of hands, and conferring it afresh in violation of law, and contrary to all the rules and regulations of the Church of God

19. Upon the edict which the illustrious king Justin made

20. Shewing, that after twenty clean copies of the edict had been written out, he sent the first, signed with his own hand, to those who were in prison $\quad . \quad \ldots \quad$. .

21. Shewing that John protested to the bishops, saying, 'See now that it is you who prevent the unity of the $\begin{array}{lllllllllll}\text { Church.' } & \text {. } & \text {. } & \text {. } & \text {. } & \text {.. } & \text {.. } & \text {. } & \text {. } & \text {. }\end{array}$

22. Shewing that the bishops were blimed and found fault with, even by the chief men of the orthudox party, because of their obstinacy and refusal to give way for the

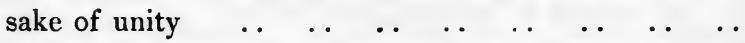

23. Upon the disputation and distress of the bishops them-

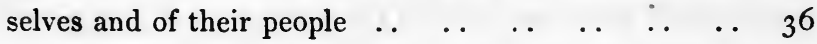

24. Upon the last disputation held, and the treacherous and $\begin{array}{lllllllll}\text { lying oaths .. } & . . & \ldots & \ldots & \ldots & \ldots & . . & . & \text {. }\end{array}$

25. Upon the grief and contrition of spirit which overtook the bishops, because they had submitted to and united themselves with the communion of Jobn, and the other $\begin{array}{llllllll}\text { Dyophysites of his party } & \ldots & \ldots & \ldots & \ldots & \ldots & \ldots & 42\end{array}$

26. Shewing that when the king learnt thereof, he sent for them, and had them lorought to the palace, and comforted them

27. Shewing that subsequently the king returned from the warm baths, and concerning the schedule that was sent them, etc. 
28. Shewing that when these things were made known to the king, and he was angry, he commanded that all the princes should assemble, and that the bishops should be tried by them in the bishop's palace $\ldots \quad \ldots \quad \ldots \quad \ldots 4_{46}$

29. Shewing that according to their orders they assembled at the bishop's palace, and that the bishops were sum-

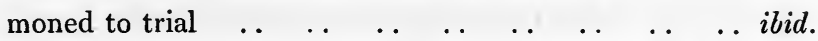

30. Containing the writer's defence against those who fall into an unfounded idea respecting him $\quad \ldots \quad \ldots \quad \ldots \quad 48$

31. Concerning Conon, the head of the heresy of the Tritheites

32. Concerning Photius, and his conduct .. $\quad \ldots \quad \ldots \quad \ldots 66$

33. Concerning the Sophists and Scholastics, and Naucleri, and others, who in the middle of the persecution were summoned and went to the capital from Alexandria ..

34. Concerning all the chiefs of the clergy of the orthodox, who were next arrested, and sent to the capital

35. Concerning some Egyptian monks, who also were summoned to the capital to foretell things future . . . ibid.

36. Upon the monasteries of men and women, which, after they had been treated violently, and some few had yielded, finally returned to their faith $\ldots$. . . 7

37. Relating that John before his death was questioned by the Christ-loving Cæsar respecting the orthodox $\quad \ldots \quad 72$

38. Shewing that even while John lived, the congregations of the orthodox finally grew in strength, and rose up

39. Upon the monastery, called Cathara, in the land of $\begin{array}{llllllllllll}\text { Bithynia } & \ldots & \ldots & \ldots & \ldots & \ldots & \ldots & \ldots & \ldots & \ldots & 75\end{array}$

40. Upon the Synodite bishops of Alexandria .. $\quad . . \quad \ldots 77$

4 I. Upon the bishops at Antioch from Flavianus and Severus 78

42. Upon the bishops at Constantinople during Justinian's $\begin{array}{llllllllllll}\text { reign } & \ldots & \ldots & \ldots & \ldots & \ldots & \ldots & \ldots & \ldots & \ldots & \ldots\end{array}$

\section{BOOK THE SECOND.}

r. Showing that when the bishops saw that they had lied unto them, they separated and abandoned the communion of the Dyophysites $\ldots \begin{array}{lllllll} & \ldots & \ldots & \ldots & \ldots & \ldots & 84\end{array}$ 
2. Concerning Paul the patriarch, and the writing which he made, and which was found out $\ldots \quad \ldots \quad \ldots \quad \ldots 8_{5}$

3. Concerning Stephan, bishop of Cyprus ; and the summons of Paul, and his journey to the capital from his place of exile, and subsequent flight $\ldots \quad \ldots \quad \ldots \quad 22,87$

4. Concerning John, Superintendent of the heathen .. 90

5. Concerning the trials which came upon John $\quad \ldots \quad \ldots \quad 9^{2}$

6. Concerning a vision, and no dream, but a reality, which

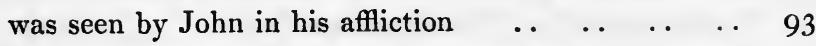

7. Concerning the imprisonments and second banishment $\begin{array}{lllllllll}\text { of the said John } \ldots & \ldots & \ldots & \ldots & \ldots & \ldots & \ldots & \ldots & 98\end{array}$

8. Concerning the flight of Paul from the episcopal palace 88

9. Concerning the praiseworthy Andrew, the queen's chamberlain and pursebearer, and the conflicts which he un-

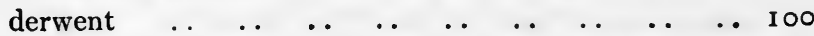

10. Concerning the merciful queen Sophia, who was orthodox 105

I I. Concerning three consuls, who also behaved bravely, and stood firmly in the truth $\quad \ldots \quad \ldots \quad \ldots \quad \ldots \quad \ldots \quad$ I06

12. Concerning two noble ladies, who also behaved bravely, and courageously stood firm $\quad \ldots \quad \ldots \quad \ldots \quad \ldots \quad \ldots \quad$ I 09

13. Concerning Sergius, and Sergius, the presbyters, and

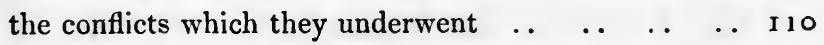

14. Concerning Andrew, who was imprisoned .. $\quad . \quad \therefore$ I I 2

I 5. Concerning the diaconate of those who tend the sick, who are thrown out into the streets of the city .. .. I I 4

I6. Concerning another and different diaconate $\ldots \quad \ldots \quad$ I 15

17. Shewing that now a persecution was stirred up every$\begin{array}{llllllllllll}\text { where } & \ldots & \ldots & \ldots & \ldots & \ldots & \ldots & \ldots & \ldots & \ldots & \ldots & \text { I } 17\end{array}$

18. Concerning what was related at the capital by the $\mathrm{Ca}-$ tholicus of Dovin, a city of the greater Armenia in the Persian dominions, and by the other bishops who were $\begin{array}{lllllllllll}\text { with him } & \ldots & \ldots & \ldots & \ldots & \ldots & \ldots & \ldots & \ldots & \ldots & \text { ibid. }\end{array}$

19. Concerning what was said by the Magi to Khosrun their king, and put in execution $\quad \ldots \quad \ldots \quad \ldots \quad$. . 119

20. Concerning the commencement of the provocation of the Christians in the Greater Armenia by the king of the Persians, etc. 
21 . Shewing what was afterwards done by Khosrun in Persarmenia, and how they revolted from him, and the whole land surrendered itself to the Romans $\quad \ldots \quad \ldots \quad 124$

22. Concerning the narrative of the Catholicus and his companions, etc.

23. Shewing that at first, on the arrival of the Armenian bishops at the capital, they went, in their simplicity, and communicated in the church of the Synodites .. 126

24. Showing what was subsequently done after the Armenians had surrendered themselves (to the Romans), and that owing to their extreme numerousness we omit ard pass by the narrative of these events .. . . ibid.

25. Concerning the dread and severe chastisement of God's righteous judgment, which in the height of the persecution quickly overtook both sides alike $\ldots$. . $\quad . .130$

26. Concerning the humiliation and torture which overtook John of Sirmin, and that he was chastised by a devil all the days of his life, because it was he who set on foot a merciless persecution. . $\quad . \quad \ldots \quad \ldots \quad \ldots \quad \ldots \quad \ldots \quad 132$

27. Showing, that when John was persecuting, he rooted out and took down all the pictures of the orthodox fathers from all the monasteries, and fixed up his own $\quad$.

28. Concerning Theodulus, the deacon, who was also a violent persecutor of Christians, and of the righteous sentence of retribution which also overtook him, when

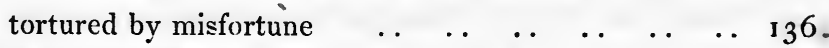

29. Concerning the king's quæstor, whose name was Ana$\begin{array}{lllllllllll}\text { stasius . . } & \ldots & \ldots & \ldots & \ldots & \ldots & \ldots & \ldots & \ldots & \ldots & \text { I } 39\end{array}$

30. Showing that as the churches of the orthodox were rooted up in the persecution by the Synodites, so shortly afterwards those which the Synodites themselves possessed were similarly treated by a certain just sentence; the altars of the churches throughout all Thrace, and up to the city wall, being rooted out and stripped by the barbarians, and they fled from before the face of the barbarians 
31. Upon the summons and arrival at the capital of the patriarch Eutychius after the death of John . . . 142

32. Concerning what was said by the archdeacon of Rome in the presence of the king canonically with boldness concerning John and Eutychius before the arrival of $\begin{array}{lllllllllll}\text { the latter } & . . & \ldots & \ldots & \ldots & \ldots & \ldots & \ldots & \ldots & \ldots & 143\end{array}$

33. Showing that when Eutychius was recalled, it was supposed by every one that he would not be permitted to return and occupy the see, until a synod had been assembled and sat and examined every thing that had been done by him and John unto one another .. $\quad$. 145

34. Concerning the images of John which Eutychius took down, and his relatives, all of whom he humbled and

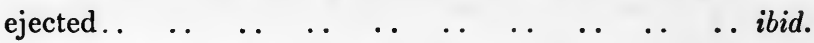

35. Concerning the books of the Quaternity, that is, the two natures after the union, which Eutychius composed $\begin{array}{llllllllll}\text { when in exile } & . & \ldots & . & \ldots & \ldots & \ldots & \ldots & \ldots & 146\end{array}$

36. Showing that Eutychius was perverted to the view of the heresy of the Athanasians, who say that these bodies do not arise, but others arise in their stead . 147

37. Showing that when Eutychius was murmured at and ridiculed and reviled by every one, he thought that he was only reviled by the orthodox $\quad \ldots \quad \ldots \quad \ldots \quad \ldots r 50$

38. Concerning Fravianus, the slave of Andrew, who had

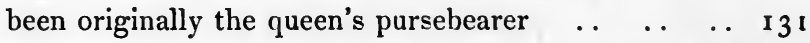

.39. Concerning a sister a nun, and the courageous conflicts she underwent, and was victorious and triumphant in

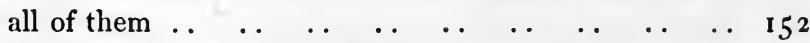

40. Concerning the Antiphon for Thursday in Passion-week, which Eutychius wished to alter, and which from ancient custom was part of the service in all churches, and substitute his own $\quad \ldots \quad$.

4I. Concerning what finally happened to John, called Superintendent of the heathen, after all his trials $\quad . \quad 157$

42. Concerning the injured Paul of Asia, who was deposed

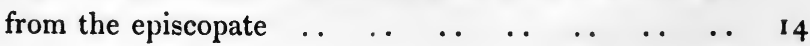


43. Showing that John endeavoured by a crafty artifice to consecrate Paul again, of which attempt we here record

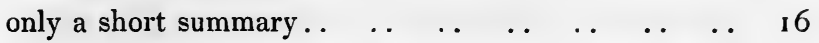

44. Concerning Deuterius, who succeeded Paul as bishop of

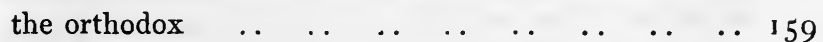

45. Concerning the sect of those who are called Condobaudites, after the name of the monastery in which they

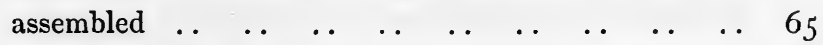

46. Concerning the monastery of the Cappadocian monks 76

47. Concerning the confused and troubled orthodoxy which

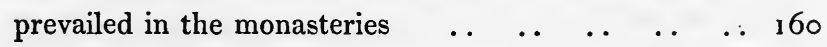

48. Concerning a marvellous sign manifested in some ani-

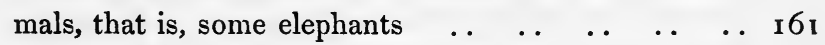

49. Concerning a conflagration which took place at the $\begin{array}{lllllllllll}\text { capital .. } & \ldots & \ldots & \ldots & \ldots & \ldots & \ldots & \ldots & \ldots & \ldots & 16_{3}\end{array}$

50. Explaining the reason why possibly the account of one event will be found recorded in a confused manner in several chapters ..

5 I. Showing that while Eutychius originally belonged to the heresy of the Samosatenians, he finally gave him-

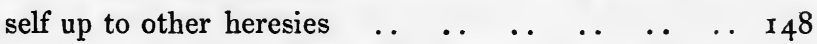

52. Showing that Eutychius was opposed to the phrase,

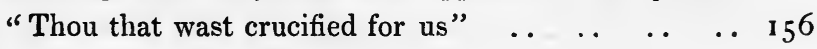

\section{BOOK THE THIRD.}

I. Concerning the commencement of the book . . . . 165

2. Showing that when the king gave way, and betook himself to evil courses, chastisement was sent down upon him from God for his good $\quad \ldots \quad \ldots \quad \ldots \quad \ldots \quad$. . 166

3. Concerning the means employed for the king's amuse$\begin{array}{llllllllllll}\text { ment, etc. } & \ldots & \ldots & \ldots & \ldots & \ldots & \ldots & \ldots & \ldots & \ldots & 169\end{array}$

4. Concerning what was said of the king's temptation .. 170

5. Concerning the appointment of the God-loving Tiberius

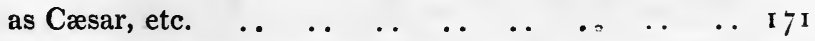

6. Concerning the end of king Justin, and the reign of the

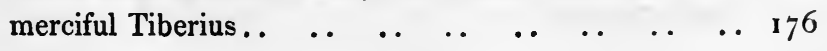


7. Concerning queen Sophia, etc.

8. Concerning the wife of Tiberius Cæsar, whose name originally was Ino, etc.

9. Concerning the arrival of the Cæsar's wife at the palace, after he had begun to reign, etc.

Io. Concerning the queen Sophia, and what happened $\begin{array}{llllllllllll}\text { afterwards } & . & \ldots & \ldots & . & \ldots & \ldots & \ldots & . & \ldots & \ldots & 183\end{array}$

I I. Concerning the commencement of the reign of Tiberius 185

2. Concerning the manner in which the Cæsar was an-

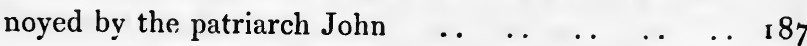

I3. Concerning the persecution commanded against here-

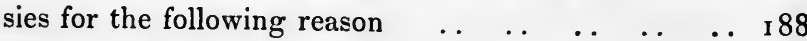

14. Concerning the Hypatia of king Tiberius, etc. . . $\quad$.. 189

I5. Concerning the persecution which was stirred up against heresies, and also against the orthodox $\quad . . \quad \ldots \quad . \quad . \quad 192$

16. Concerning the uprooting of the congregation which assembled at the church in the Marianum .. $\quad . . \quad$. 194

17. Concerning the patriarch Eutychius himself, etc. .. 195

I8. Concerning the patriarch Eutychius himself, and his

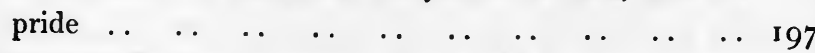

19. Concerning the opposition he made to the phrase, "Thou that wast crucified for us"

20. Concerning the heat and bitter bile and utter hatred entertained by Eutychius against the whole party of the orthodox

21 . Showing that the victorious king, in whose nature was nobleness and humility, though occupied with the cares of the wars, did not often give way to persecution, according to the wish and urgency of the persecutors .. 201

22. Concerning the gentleness of king Tiberius .. .. 202

23. Concerning the buildings which king Tiberius erected in the palace

24. Concerning Justin's Pharos, which king Tiberius rooted up

25. Concerning the trials occasioned by the numerous wars which surrounded king Tiberius from the time he was made Cæsar. 
26. Concerning the Romans and Goths who were Arians, and asked for a church to be given them . . . . 207

27. Concerning the audacious doings of the heathens, and what was justly stirred up against them $\quad$. $\quad . \quad 2 \quad \ldots 209$

28. Concerning what was done at Edessa respecting the

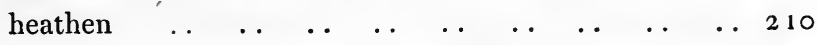

29. Concerning the tumult, and what was done at Antioch the Great after these things $\quad \ldots \quad \ldots \quad \ldots \quad \ldots \quad \ldots 2$ I 3

30. Concerning what was done and carried on at the capital

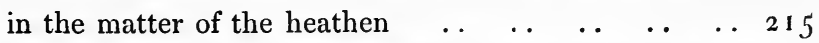

$3 \mathrm{I}$. Concerning the riot at the capital from the zeal of the Christian people because of the quest after the heathens ibid.

32. Concerning the entry of the king into the city, and

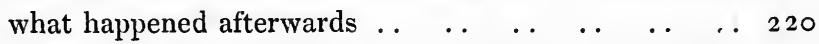

33. Concerning what was subsequently done in the trial of

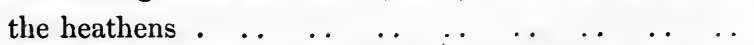

34. Concerning the quest subsequently made after the heathen 224

35. Concerning the bitter murder of Eustochius, bishop of Jerusalem, which was perpetrated by his slave . . . 227

36. Concerning the great monastery newly built in the land of Asia by John, Superintendent of the heathen, in a mountain of (near) the city of Tralles $\quad \ldots \quad$. . $\quad$. 229

37. Concerning the opposition and trials which arose against the said monastery of Derira (? Erira), through the

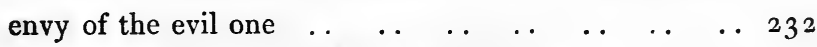

38. Concerning the sudden death of Eutychius.. . . . 233

39. Concerning John, who, from being the pursebearer of the former (John), was subsequently chosen (to be

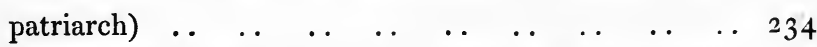

40. Concerning Mondir, the son of Harith, and the accusa-

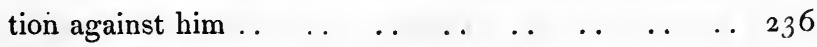

4I. Concerning the visit of Mondir to Magnus, and his $\begin{array}{lllllllllll}\text { arrest, etc. } & \ldots & \ldots & \ldots & \ldots & \ldots & \ldots & \ldots & \ldots & \ldots & 238\end{array}$

42. Concerning the four sons of Mondir, and what they did 240

43. Concerning the second journey thither of Magnus, and the death which overtook him, and put an end to his

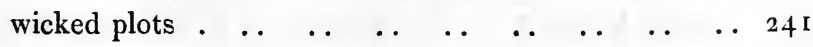


44. Concerning the peace and short respite which the orthodox enjoyed at the capital.

45. Concerning the famine which suddenly happened at the capital.

46. Concerning the excessive mortality of children.

47. Concerning king Tiberius, and the time of his death.

48. Concerning king Tiberius' purpose of bringing about unity in the church.

49. Showing that king Tiberius' wife from ignorance hated the orthodox.

50. Concerning the three queens who dwelt at one time in the palace after the death of Tiberius.

5 r. Concerning John, who was patriarch after Eutychius.

52 . Concerning the mercifulness and liberality of the patriarch John.

53. Concerning the struggles of the patriarch John against the heathen.

54. Concerning the imprisonment of Mondir, and his banishment from the capital to a distant place of exile.

55. Concerning one of the princes of Mondir whose name was Sergius, a believer, who was also sent into exile.

56. Concerning the arrival of Noman, the son of Mondir, at the capital.

\section{BOOK THE FOURTH.}

The first four chapters and part of the fifth are lost.

6. Concerning the barbarian people of Nubia, who were instructed in Christianity, together with the cause of their being instructed ..

7. Concerning the arrival of the blessed Julian and his companions in the land of Nubia, and their reception, and the other things which they there accomplished by

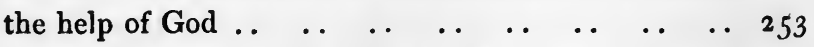

8. Showing that when the blessed Theodosius departed from this world, he remembered this people, and commanded that Longinus should be immediately made 
their bishop, and sent thither, inasmuch as Julian also

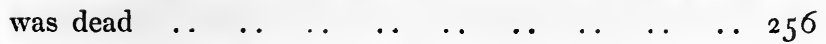

9. Concerning what was written to Longinus by Theodosius, archpresbyter, and Theodore, archdeacon, of the clergy of the church of the orthodox at Alexandria .. 258

10. Concerning two bishops, John and George, who at that time had been sent from Syria to Longinus, and concerning Theodore, who fell into temptation .. . . 259

I I. Concerning those things which malignantly and savagely and confusedly, and contrary to all canonical order, were done by the Alexandrians after these things, together with the consecration of Peter.. .. . . . $\quad 26_{4}$

12. Showing that though the question had not been taken into consideration, and examined by them as orderly men, whether the former (bishop) had been appointed in a fitting and orderly manner, (or not,) they con-

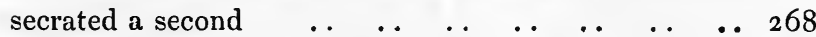

13. Concerning Theodore, the first bishop, who, against his will, was appointed and consecrated upon compulsion

I4. Concerning Paul the patriarch, spoken of above, and concerning the unfounded idea respecting him, and his deposition contrary to rule by Peter, who was himself

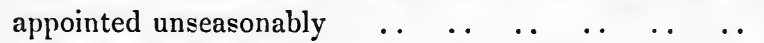

I 5. Concerning the division and quarrel, which by the instigation of Satan took place between Jacob and Paul, contrary to the rule of propriety. . . . $\quad \ldots \quad \ldots \quad \ldots$

16. Concerning the deposition of Paul by Peter, who was the second consecrated (to the see), contrary to justice, and the entire canonical order of the church .

17. Concerning the arrival finally of the blessed Jacob at Alexandria, and the rest of his acts $\ldots \begin{array}{lllll}\text {. . } & \ldots & \ldots & 278\end{array}$

18. Concerning the departure of the blessed Jacob and the other bishops who were with him from Alexandria .. 280

19. Concerning the division and quarrel and schism which ensued not only in Syria, but also in Cilicia and Isauria and Asia and Cappadocia and Armenia, and especi-

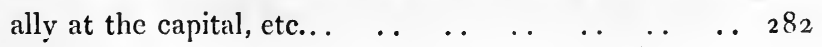


20. Concerning the message sent by Paul the patriarch to Jacob, respecting an inquiry and canonical examination of the charges brought against him $\ldots \begin{array}{lllll} & \ldots & \ldots & \ldots & 283\end{array}$

21. Concerning the zeal and earnestness of Mondir, son of

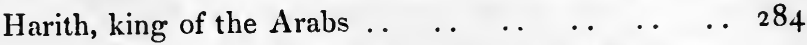

22. Concerning the journey of Longinus, and Theodore, whom he had made pope, into the regions of Syria, and to the side of the Paulites $\ldots \begin{array}{llllll} & \ldots & \ldots & \ldots & \ldots & 285\end{array}$

Chapters 23-29, and the commencement of the 3 oth, are lost.

3I. Showing that there were divisions also in most of the chief monasteries, and that being at variance, they parted and withdrew, some standing up for the Paulites, and some for the Jacobites . $\quad \ldots \quad \ldots \quad \ldots \quad \ldots 288$

32. Concerning the meetings of numerous abbots, and the message they sent to Jacob, and the bishops who were

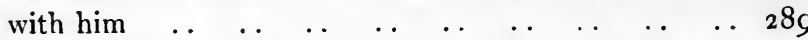

33. Showing that an impulse suddenly seized upon the old man Jacob to go to Alexandria, and that on his journey he departed from the world . . .

34. Concerning an unfounded idea and full of wickedness, which some persons imagined and gave utterance to, respecting the sudden death of the blessed Jacob and his companions, who, having no fear for the account they must give for every idle word, spread, abroad a report, that some Paulites forsooth murdered the old man Jacob and his companions with stones . . . 292

35. Concerning the three ambassadors who, in the year 888 , were sent to confer about a peace upon the marches, and who strongly took the side of Paul . . . . . 293

36. Concerning Mondir, the son of Harith, king of the Arabs, and all his hordes, who were grieved and vexed on account of the Paulites and Jacobites .. . . . $29+$

37. Concerning the second journey of the clergy of Alexandria to the capital, and their imprisonment in monasteries 
38. Concerning the death of Theodosius, archpresbyter, and Ecclesiecdicus of the church of the Alexandrians, who died in imprisonment at the monastery of Nitria .. 296

39. Concerning the journey of Mondir, the son of Harith, king of the Arabs, to the capital, and what was done by him there in his zeal because of the schism between the Jacobites and Paulites ..

40. Concerning the meeting, and promises of peace and union made by the two parties to one another by the mediation of the illustrious Mondir $\quad$.

4r. Concerning Damianus, a Syrian, who also, contrary to canonical order, was appointed patriarch at Alexandria $\begin{array}{llllllllll}\text { after Peter .. } & . & \ldots & \ldots & \ldots & \ldots & \ldots & \ldots & \ldots & 300\end{array}$

42. Concerning the departure of the Alexandrian clergy, and subsequently of Mondir himself from the capital.. 304

43. Concerning Damianus, and his falsehood, and the upsetting which he iniquitously brought about of the peace made at the capital; and concerning the clergy who also turned round and were false to their

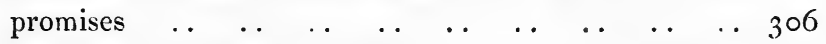

44. Concerning what was done also in the land of Syria, occasioned by the letters of Damianus, without order, and contrary to the laws of the church $\quad \ldots \quad \ldots \quad . \quad 308$

45. Concerning the letters of the monasteries in the east in their own handwriting to $J_{0 h n}$ of Ephesus, who was dwelling at the capital, inviting him to communion with the patriarch, whom they had consecrated. . . .. ibil.

46. Apology of the author, showing that he writes without partiality or passion towards either party $\ldots$.. $\quad . \quad 310$

47. Showing that Paul finally went and hid himself in a mountain of Isauria in a cave, as they said, for four

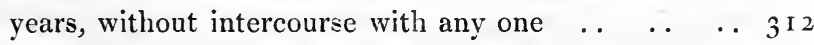

48. Concerning Theodore, who was made pope of Alexandria by Longinus and the rest $\ldots \begin{array}{llllll} & \ldots & \ldots & \ldots & \ldots & 313\end{array}$

49. Concerning the commencement of the conversion to Christianity of the people whom the Greeks call Alodrei, who are supposed by us to be Cushites $\quad . . \quad$. 315 
50. Concerning those who were sent by the Alexandrians to the people of the Alodæi $\quad \ldots \quad$.

5 I. History of the journey of the blessed Longinus to the land of the Alodxi, and of their joyful conversion and

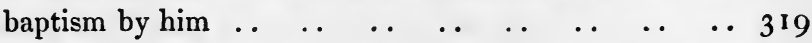

52. Concerning the letter of the king of Alodæa to the king $\begin{array}{llllllllllll}\text { of Nubia } & \ldots & \ldots & \ldots & . & \ldots & \ldots & . . & . & . & 320\end{array}$

53. Part of a letter of bishop Longinus $\quad . \quad$.

54. Concerning the concealment of Paul the patriarch . 327

55. Concerning Theodure, who was made pope of Alexan-

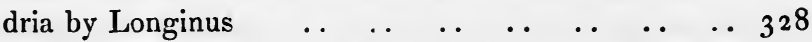

56. Concerning the journey of pope Theodore to the island $\begin{array}{lllllllllll}\text { of Cyprus } & \text {. } & \ldots & \ldots & \ldots & \ldots & \ldots & \ldots & . & \text {. } & \text { ibid. }\end{array}$

57. Concerning the end of Paul the patriarch, how it was 329

58. Concerning the decease of Paul and Jacob, how it happened to them both one after the other in a troubled manner

59. Concerning what after their death was said and done by the parties of the Paulites and Jacobites, who were at variance with one another $\quad . \quad$.

60 . Concerning the journey of Peter, who had been consecrated in Syria, to Alexandria ..

61. Concerning the congress of the bishops of both parties, etc., who for a year, more or less, contended and de-

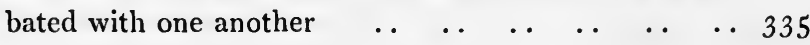

\section{BOOK THE FIFTH.}

1. Concerning the commencement and time when the Tritheites began the laying on of hands, and took measures, that their bishops might fill all quarters with their impudent and polluted heresy $\quad \ldots \quad \ldots \quad$.

2. To the same effect, namely, that they consecrated and sent everywhere numerous bishops of their party . . 54

3. Concerning the sectaries of the heresiarchs Conon and $\begin{array}{lllllllllll}\text { Eugenius } & \ldots & \ldots & \ldots & \ldots & \ldots & \ldots & \ldots & \ldots & \ldots & \text { ibid. }\end{array}$

4. Concerning the release of Conon from exile $\quad \ldots \quad \ldots \quad 55$ 
5. Concerning the division of the Cononites into two $\begin{array}{lllllllllll}\text { heresies } & . & \ldots & \ldots & \ldots & \ldots & \ldots & \ldots & \ldots & . & 56\end{array}$

6. Concerning the journey of both parties to the land of Pamphylia, to pervert it, and the death of Eugenius $\begin{array}{llllllllllll}\text { there } & . & \ldots & \ldots & \ldots & \ldots & \ldots & \ldots & \ldots & \ldots & \ldots & 57\end{array}$

7. Concerning the message sent to Conon by John of Asia at the capital, and the cause of his (Conon's) journey thither

8. Concerning the imposture of the Tritheites, who, by a crafty artifice, professed to wish for union, but did not

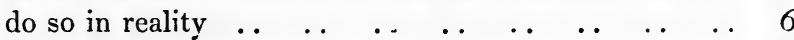

9. Shewing that they were guilty of the same at Alexan-

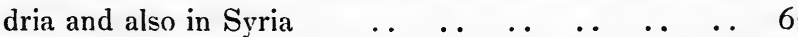

ı. Concerning the great book of lacerations (catena of extracts) which the Tritheites tore out and put together

I I. Concerning the meetings of the bishops of the Tritheites

12. Concerning a solitary bishop of the Tritheites, who returned to the Orthodox, and made an act of recantation,

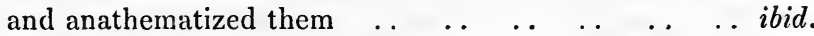

I 3. Concerning the time of the reign of the victorious king Maurice, which according to the rule of propriety ought to have been written at the head of the book, but it did $\begin{array}{llllllllll}\text { not so occur } & \text {. } & \text {. } & \text {. . } & \text {. . } & \text {. } & \text {.. } & \text {. } & \text {. . } & 349\end{array}$

14. Concerning king Maurice, and his marriage banquet, and his son, whom afterwards he begot in the palace, etc. $35 \mathrm{I}$

I 5. Concerning those whose habit it was, on pretext of the faith, to fall upon men, and rob and steal the goods of others, and who did not rest quiet till they had informed the king about the Orthodox $\quad$.

r6. Concerning the persecution of the Church of the Arians 354

17. Concerning Gregory, bishop of Antioch, and his journey to the capital, and the request he made to the king 225

18. Concerning the parents, and brothers, and sisters, and very numerous relatives, whom king Maurice sent for and brouglit to the capital, and enriched and ennobled $\begin{array}{lllllllllllll} & \text { them } & \ldots & \ldots & \ldots & \ldots & \ldots & \ldots & \ldots & \ldots & \ldots & \ldots & 355\end{array}$ 
19. Concerning Domitianus, metropolitan of the city of Me-

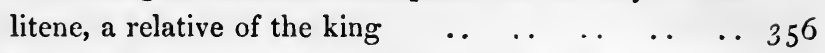

20. Shewing that when Maurice began to reign he found the palace emptied of its treasures, and came into great

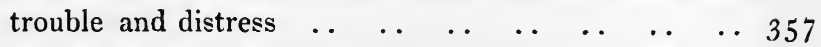

$2 \mathrm{I}$. Concerning the disturbers, and persecutors, and plunderers of others, who constantly were annoying the ears of king Maurice, and the rest of his court .. . $35^{8}$

22. Concerning the rebuilding of the desolate city of Arabissus in Cappadocia, which was king Maurice's native $\begin{array}{llllllllllll}\text { town } & . & \ldots & \ldots & . . & \ldots & \ldots & \ldots & . . & . & . & 361\end{array}$

23. Concerning the destruction by an earthquake two years afterwards, more or less, of the rebuilt town of Arabissus ..

\section{BOOK THE SIXTH.}

1. Concerning the commencement of the book 366

2. Concerning the war conducted by the patrician Marcian, and what subsequently happened to him $\ldots 3^{6} \quad . \quad 37$

3. Concerning the causes of the king's wrath against Marcian, in respect of Mondir, king of the Arabs .. . . 370

4. Concerning the king's letters to Marcian and Mondir $37^{2}$

5. Concerning the march of the king of the Persians, and the capture of Dara, in the year $88_{4}$, etc.

6. Concerning the capture of the city of Apamæa, and the devastation wrought that year, while the Persian king $\begin{array}{lllllllllll}\text { sat before Dara } & . & \ldots & \ldots & \ldots & \ldots & \ldots & \ldots & \ldots & 3^{8} 5\end{array}$

7. Concerning two thousand beautiful virgins, who, at the king's command, were selected to be sent as a present to the barbarians, and the wonderful and astonishing act which the virgins committed in their zeal for $\begin{array}{llllllllll}\text { Christianity } & \ldots & \ldots & \ldots & \ldots & \ldots & \ldots & \ldots & \ldots & 387\end{array}$

8. Concerning the short truce which was made at that time for three years in the provinces of Syria, and the expedition of the king of the Persians into the territory of the Romans, that is, into Armenia and Cappadocia 
9. Concerning the burning of Melitene, and the subsequent events ..

10. Concerning what finally happened to the Romans in $\begin{array}{lllllllllll}\text { Persarmenia } & \text {. } & \ldots & \text {. } & \ldots & \ldots & \ldots & \ldots & \text {. } & 398\end{array}$

I I. Concerning the Persarmenians who had given themselves up to the Romans $\quad \ldots \quad \ldots \quad$.

I 2. Concerning the ambassadors of the Romans and Persians, who met on the part of the two realms upon the borders, mutually to judge of and examine all the matters on account of which wars had been stirred up, and for which they blamed one another $\quad \ldots \quad \ldots \quad \ldots \quad \ldots 403$

I 3. Concerning the inroad which the Persians made into the Roman territories, immediately, at that very time 406

I 4. Concerning Count Maurice, etc., and the stratagem and

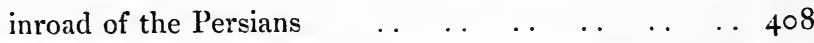

I5. Concerning the subsequent actions of Maurice .. . . 4 I I

16. Concerning Mondir, the son of Harith, and Maurice, how after these things they invaded in concert the

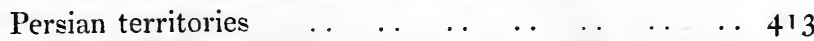

I7. Concerning a Marzban of the Persians, who crossed over, and burnt the district of Tela a second time, and that of Edessa, and Haran, etc. . . . . . . . . . 4 I 4

I8. Concerning Mondir, the son of Harith, and his victory

19. Concerning what was done by the captires imprisoned in Antioch, which Khosrun built in Persia, and has imprisoned there all his captives from the Roman terri-

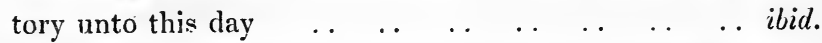

20. Concerning the death of Khosrun, king of the Persians, and of the duration of his reign, etc. . $\quad \ldots \quad \ldots \quad \ldots$

2I. Showing that Khosrun gave proof that he was sorry and vexed at the rupture of the peace between the kingdoms, and that even after much devastation had taken place in both realms, he wished to reestablish peace, and made many concessions $\quad \ldots \quad \ldots \quad \ldots \quad$. . 420

22. Concerning the son of Khosrun, king of the Persians, who reigned after him, and whose name was Hormuzd 423 
23. Concerning the reasons whence the ill feeling originally arose, and the peace was broken between the kingdoms 424

24. Concerning a base people who are called Avars.. . . 428

25. Concerning the people of the Slavonians, and the devastations which they committed in Thrace, in the third year of the reign of the serene king Tiberius .. $43^{2}$

26. Concerning the battle of the Romans and Persians, which happened before the city of Tela, on a day of the month Haziron, in the year 892 , as follows; ..

27. Concerning Maurice, who was over all the generals in the East

28. Concerning a battle which took place in Armenia, and the other matters administered and done there .. $\quad .4437$

29. Concerning a certain Persian impostor, who gave himself out as the king's son $\quad . \quad \ldots \quad$.

3o. Concerning Sirmium, a great city in the kingdom of the Gepidæ, which the Avars took by violence

31. Concerning the journey of Narses the Spatharius

32. Showing that finally when what they hoped did not come to pass, the city of Sirmium was given up to

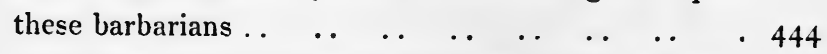

33. Concerning the burning of Sirmium, which happened subsequently

34. Concerning the record of numerous wars, and finally of the war conducted by count Maurice, and the capture of Arzun ibid.

35. Concerning another fort which Maurice built opposite Sophene, the name of which is Shemkoroth $\quad . \quad \ldots 446$

36. Concerning another fort, the name of which is Ocba, which is situated on the Chalat, in the land of the Persians

37. Concerning an ambassador of the Persians, who happened at that time to be sent to the king of us the Romans

38. Concerning the journey of an arnbassador of the Romans, to confer with the king of the Persians about a peace 
39. Concerning the Persian ambassador, who was sent a second time to the king of the Romans.

40. Concerning the immense devastation wrought during a long period by the two states against one another.

4I. Concerning the rise and subsequent fall of the principality of the Roman Arabs.

42. Concerning some of the princes of the Arabs, who went and surrendered themselves to the Persians.

43. Concerning some famous princes among the Persian Marzbans, who were taken prisoners, and sent in chains to the capital.

44. Concerning another war in the third year (of Maurice), and the victory which God gave the Romans.

45. Concerning the base people of the barbarians, who from their long hair are called Avars.

46. Showing that the Avars made an expedition, and captured numerous important cities and forts.

47. Concerning the terror and commotion which fell upon Constantinople, while we also were there.

48. Concerning the capture and laying waste of the land of the Slavonians.

49. Concerning the laying waste of the city of Anchialus, and concerning the warm baths there. 



\section{ECCLESIASTICAL HISTORY}

\section{OF \\ JOHN BISHOP OF EPHESUS.}

DuRing the reign of Justinian, the empress Theodora, a devoted member of the Monophysite party, had built and endowed at Constantinople numerous monasteries, in which she placed bodies of monks drawn chiefly from the Asiatic provinces of the Roman empire. Fostered by the empress they naturally were looked upon with displeasure by the patriarchs of Constantinople, whose authority they disowned; for already their own organization was complete, and from the death of Severus, patriarch of Antioch, A. D. 542, to the present day, there has been maintained in the East a succession of Monophysite patriarchs, to whom all the members of the party owe allegiance. But as lesser evils close at hand are more felt than greater ones at a distance, so probably the residence of Theodosius, the exiled patriarch of Alexandria, at Constantinople, annoyed the ecclesiastical authorities there far more than the rapid increase of Mono- 
physitism in the East. For though Justinian had removed Theodosius from his see, yet he was received at court with so much distinction by Theodora, and so thoroughly supported by her influence, that his disgrace was turned into a triumph, and during his thirty years' exile, to his death in A. D. 567, he exercised paramount authority over the numerous monasteries and churches of his party at the capital, as well as in Egypt his proper sphere.

The patriarch moreover, who had been intruded into the Constantinopolitan see upon the refusal of Eutychius to subscribe to a notion of Justinian that the body of our Lord was incapable of carruption, was by no means a man likely to bear with any interference with his authority patiently. For John Scholasticus was more of a lawyer than a theologian, and a thorough man of the world; and no. sooner therefore had the health of Justin failed, and John was free to carry out his plans, than he determined upon crushing the whole Monophysite party.

The narrative of this persecution is intro-

I. 3. duced by a pathetic lamentation, in which our historian especially quotes the prophecy of our Lord, that "the brother shall deliver the brother to death :" a prophecy, he says, not to be restricted to the glorious company of the Apostles, but equally belonging to all members of the Church; and especially true in the case of his own party, as being persecuted, not by heathens, 
but by their fellow-Christians, at whose hands, restrained neither by mercy nor the fear of God, he protests that they met with such cruel and pitiless treatment that heathens could have done no more.

It was, however, the breaking out of this persecution which induced him to add this third part to his Church History. For he had previously completed in twelve books, divided into separate chapters, each with distinct headings, the history, or literally, the narratives and tales of the church, from the days of Julius Cæesar, the first king of Rome, to the sixth year of Justin II, Justinian's sister's son: and in it he declares that he had borne willing testimony to Justin's zeal and anxiety for the unity of the church, his earnest desire being to speak the truth whatever might befal. For this concluding portion he requests the indulgence of his readers, if they find it destitute of arrangement and with occasional repetitions : for it was written under circumstances of great difficulty, piecemeal as opportunity permitted; nay, he even apologizes for writing it at all: " for I am fully aware that the times of the world are on the wane, and all but spent : yet have I recorded these events, because I would have men know them during the period, short though it be, ere this woebegone world shall pass away."

He introduces his narrative by a string of quo- I. 4. tations from " the groans and lamentable cries of the much suffering Jeremiah, and the glorious 
prophet Isaiah," spoken originally of Jerusalem, but applied by him to the Monophysite church: doubtless their most mournful expressions seemed to him, and that rightly, to find their fulfilment in the events of his own time; for it is thus that Scripture is the support and consolation of all ages, because its words whether of joy or sorrow are not confined to one fulfilment, but belong to all times and all individuals. These however we may pass by, and proceed to his history.

I. 5. For the long period then of more than forty years, all the congregations of the orthodox church had enjoyed a time of peace and tranquillity both in the capital and its suburbs; and in entire liberty, fully and freely and without fear, had assembled wherever they chose, and performed all the mysteries and ordinances of the church. But suddenly in the holy days of the Lenten fast, on the Saturdaya before Palm Sunday, from the urgency and wicked violence of him who governed the church of the capital, namely John of Sirmin ${ }^{b}$, a village in Syria, and from his numerous slanders against the whole party of the orthodox, the victorious Justin was

a The words literally are, 'on the Sabbath of the dawn of the first (day) of the week of Hosannahs.' In the Syriac service.books, Saturday is still called the sabbath, and Friday " the preparation" парабкєиं, Mark xv. 42. The other days are called, " one in the week," "two in the week," \&c. The week commencing with Palm Sunday is " the week of Hosannahs," and Passion week " the week of the mystery."

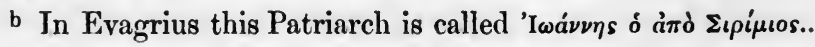


stirred up unto great wrath, and in an angry decree commanded that all the places where the believers assembled should be shut up, the altars in them razed, their priests and bishops seized and cast into prison, and all who met there for worship driven away and dispersed, and commanded never to enter them again. And other similar decrees and injunctions were issued in great wrath, whereas up to that time they had been permitted in peace and quietness to celebrate the rites of their religion.

The loss of a portion of the manuscript keeps us in ignorance of the measures which immediately followed. When the narrative recommences, we find the prefect sitting in judgment upon (apparently) an old man, who thus indignantly apostrophizes his judge ; “... Why I. 9.

sittest thou as a Christian, and judgest the servants of God after the fashion of a heathen? Thou art not a living man, if thou dost not quickly burn me, a weak old man, and roast and eat me." Similar emphatic protests against the cruelty of the persecutors occur in other parts of John's history. The prefect on hearing himself thus addressed was alarmed, and moved by the prisoner's great age, commanded him to be conducted to the bishop: but he in great anger sent and imprisoned him at Heraclea in Thrace, where during two years he was so closely confined that none of his friends were permitted to see him; and as no change of raiment was provided for him, he was soon covered with ver- 
min : and when one of his former disciples who had heard of his state procured for him a supply of clothing, he was not allowed to give it him even by the hands of others. At the end of two years he sickened and died : and in his last words pronounced a solemn anathema, in case he should be buried by the Synodites ${ }^{c}$, or if any one of them should dare to minister at his funeral, or offer over him a prayer. A crowd of orthodox Romans therefore in the neighbourhood undertook the charge of his burial, and wrapping his body as that of an illustrious martyr in cere cloths and spices, they conducted him in solemn procession towards the capital, uttering as they went cries of indignation and shame at the persecution of such holy men: and finally a party of believers from the capital went out to receive the corpse, as being that of a saint.

I. ı. The patriarch's chief attack however was directed against the monasteries, of which there existed many both in Constantinople itself, and its neighbourhood, and of these several had a very large number of inmates, especially the convents, in which the late queen Theodora had placed the nuns who in a previous persecution

c By the Synodites are meant the followers of the general council of Chalcedon, A. D. 45I, in which the doctrine of the two natures in Christ was authoritatively decreed. His own party John styles "the orthodox," "the believers," \&c. So Leontius de Sectis says that Justinian was notoriously ovvoditrns, a follower of the couneil of Calcedon. 
had been driven out of Antioch, Isauria, Cilicia. Cappadocia, and the Roman provinces in the east. So powerful in fact were some of these establishments that they numbered more than three hundred members. Upon these then also descended the storm and tempest of persecution, and a murky cloud and terrifying darkness covered them; for there came clergy and laics with the prison-keepers, and sergeants, and along with them the body-guard of the prefect of the city; who being let loose upon them with barbarous violence surrounded the convents, and like a troop of wolves breaking into and falling upon a fold of sheep, so they rushed in, and laid their destructive hands upon the inmates, who were Christ's own lambs; and the clergy, who had brought with them consecrated bread, dragged and pulled them by main force to make them receive the communion at their hands. And they all fled like birds before the hawk, and cowered down in corners, wailing and saying, 'We cannot communicate with the synod of Chalcedon, which divides Christ our God into two natures after the union, and teaches a quaternity instead of the Holy Trinity.' But with angry words and main force they were dragged up to communicate; and when they held their hands above their heads, in spite of their screams their hands were seized, and they were dragged along, uttering shrieks of lamentation, and sobs, and loud cries, and struggling to escape. And so the 
sacrament was thrust by force into the mouths of some, in spite of their screams, while others threw themselves on their faces upon the ground, and cursed every one who required them to communicate by force. Some of them then they thus reduced to obedience; but others who still resisted, and would not yield, they separated from the rest, and expelled them. from their convents, and delivered them into the hands of the Roman sergeants, by whom they were hurriedly torn away, and taken to the city, and dispersed there among various houses and prisons; and, as was said, they there met at the hands of some with treatment too wanton and abominable for us to mention. But there is One, Who seeth their cause, even the righteous Judge, Who shall judge their cause and avenge their quarrel.

And thus then, and in this savage and barbarous manner, were the convents treated, both of men and women.

I. I I. The person who stirred up and occasioned and put into execution all these evils, was the John mentioned above as head of the church in the city. For he by his slanders inflamed the king against the whole party of the believers, and so worked upon him that at length he obtained permission to treat them as he liked: whereupon, by means of his satellites, he poured upon their ranks every where the blight of his wicked nature. For his measures were not con- 
fined to the city, nor to his own diocese, but he wrote letters also to other countries, that he might stir up the like troubles and persecutions and miseries also there. He even went in person to the convents both of men and women, and to houses, and forced and compelled the inmates to communicate with him, and whoever persisted in refusing, both men and women, whether monks or clergy or nuns, he commanded in cruel wrath and without mercy, that they should be imprisoned separately in various monasteries, and finally pronounced against them harsh sentences of death. He managed also so to deceive and stir up their victorious majesties, that they did whatever he wished, and visited the convents one after another, the patriarch going to each first in person, accompanied by his clergy, to celebrate divine service there and reconsecrate them; after which he proclaimed in them the 'divided synod,' and fixed up his own pictures, and put in them clergy to celebrate the communion every first day of the week, and on the festivals, and days kept in memory of the saints. The following day the king visited the monasteries in person; and the next day the queen in like manner, offering each of them gifts, and restoring such monks as either had, or were ready to make their submission. But such as resisted were exiled, or sent into close confinement, or made over without mercy to the prætorian guards to torture, or given up to whatever bitter and cruel scourgings and ill treatment 
the fierce and vindictive malice of their persecutors suggested to them.

The measure however which the orthodox most deeply resented was the annulling of the orders of their clergy. And this, as our historian represents it, was the result of mere caprice on the patriarch's part, who was so blinded by mere party rage as to be unable to perceive that such a proceeding was "contrary to reason and justice, and the canons." Probably however he was principally influenced by the desire of increasing the power of his see; for just at this time the bishops of Constantinople were making that attempt, in which Rome finally succeeded, of raising themselves to the headship of the Christian church. Constantinople was not merely then "a second Rome," as they delighted to call it; lut from the disastrous state of Italy, it was raised in importance far above its western rival, and the residence of the emperor there, gave to its patriarch the opportunity of gaining for his plans the support of the secular power. Already we find them assuming the title of CEcumenical bishop, so sharply rebuked a few years later by Gregory the Great of Rome ; and probably John's purpose was to extend the authority of his see, by compelling bishops beyond its limits, such as Paul of Antioch, Stephan of Cyprus, \&c., to submit to reconsecration at his hands, and return to their dioceses as his suffiragans. The accusation of heresy gave him an excuse for meddling beyond his own proper limits, and we shall find 
him trying his hand, though not successfully, with Alexandria itself. Be this however as it may, the narrative is as follows:

The bishop therefore being full of the spirit I. г2. of fierce opposition, and led away by violence and heat, and as a man blinded in the vision of his eyes, so he being blinded by the passion of hatred in his soul, and intoxicated as it were, ventured, after contriving to force and drive into communion with him by savage tyranny and violence, many priests of the orthodox party: after, I say, they had communicated with him, and been received according to their rank in the priesthood, the presbyters being received by him as presbyters, and officiating at the administration of the sacrament on an equal footing with his own presbyters, and sitting in a row with them inside the chancel; and the deacons also in like manner performing in company with his own deacons their appointed part in the services; and that not once merely or thrice, but on as many as thirty-six several occasions in all the offices of the church: after they had thus officiated with him in right of their previous ordination, and fulfilled all the order of their priesthood, then, after all this, the cruel thought entered his mind, as though he had been but a young boy, and violently, being elated with pride, and drunken with power and haughtiness, he gave orders, saying; 'We command all those who have given in their submission to us after being our opponents, that they be deposed from their 
former priesthood, and be made priests by us anew.' And thus he now deposed them all, after they had acted as priests with him and in his presence thirty-six several times by right of their former ordination by the orthodox, and ordained afresh all who had submitted to communion with him. And great was their dismay and trouble at this proceeding, and they cursed and reviled both him and his lawless ordination. Several of them thus reordained he placed among the clergy of his own church : but many even of his own party blamed the step he had taken, as done wickedly and violently by him, in violation of church law and canonical order. Nor did it suffice him to act thus in his own person, but he even wrote letters to other countries, urging upon the bishops to follow his example, and do as he had done: his object being, not to bear the odium and blame alone of these illegal and disorderly doings, but hoping that others also would make themselves liable to similar complaints.

Unexpected as was the outbreak of the persecution at the hands of the patriarch, still it had not been entirely unforeseen by the more thought-

I. I3. ful members of the orthodox party. For there had been before revealed to a worthy monk, in a vision of the night, what immediately and without delay was about to happen in the church of God. 'For he saw a lofty and broad mountain, on the southern side of which was a vast plantation of numerous churches, built row upon row, 
until they covered a vast extent, standing close together, and being beautiful and comely and many in number. And he saw, and lo! suddenly John bishop of the royal city came, with clergy and many people with him, and ran upon them with violence, and began to root up and level with the ground all those churches: and he rooted up and levelled also the altars of them all, until he had made an end of them.' And quickly after this vision, after the interval of a few days, this very thing came to pass; for he came forth, and rooted up and overthrew the numerous meeting-houses of the churches of the believers that were in the city and in all its suburbs, according to the revelation, and according to the vision that had been foreshewn, and which manifestly in a short time was fully accomplished.

The patriarch's main difficulty, however, lay with the Monophysite bishops; and he selected Paul of Asia, bishop of Aphrodisias, and metropolitan of Caria, as the first object of his attack : and his proceedings shew how vast and despotic was the power to which the patriarchs of Constantinople had attained. For Paul, as John tells I. I 4. us, was an honest and simple-minded old man, and was dwelling quietly in his monastery, when the patriarch sent his emissaries and arrested him, and threw him into chains, and imprisoned him in his palace: and by the severity of his treatment compelled him at length to submit to communion with him. He then sent him back 
home, but wrote at the same time orders to the synodite bishop there to depose him from his episcopal office, and consecrate him afresh bishop of Antioch, a city of Caria. Which also was actually done, and they deposed him ; and, as though they imagined that they had really stripped him of the priesthood, they now ordained him afresh, as if he had been a layman. And this became a mockery and derision to the actors themselves, and to his own people; and his clergy called him " the double-dyed." Whether Paul had been previously deprived of his bishopric does not appear, as John refers to the missing portion of his history for the reason why he was dwelling " in his monastery ;" but probably he was under restraint there, and evidently had been previously removed from the discharge of his episcopal functions at Aphrodisias.

In a subsequent part of his history John relates the adventures of Paul at greater length, and even gives the very words of the recantation which the patriarch wrung from him. For apparently forgetting that he had already narrated

II. 42. to us his history, he writes as follows; "The great sorrow of Paul also deserves to be related, who was a man honest and peaceable, and humble and guileless, and dwelt like Jacob in the tabernacle of his monastery, in the land of Caria, for a long time. And when John of Sirmin heard of him, he sent at once into Asia, and brought him bound and in chains to Constantinople, and imprisoned him in his palace in sore misery : and 
by bonds and many tortures he forced him to submit to receive the communion at his hands. And because he felt shame at the gray hair and venerable character of the man, he did not reveal the fraud of his heart, and what he purposed concerning him. But after he had brought him to submission, and made him obedient to his will, he sent him to the bishop of Aphrodisias, with a letter in these words: 'Depose this man from his bishopric, and consecrate him afresh, and set him over Antioch, a city under thy dominion (in thy diocese).' And when he had received Paul and the letters, he at once laid hands on him,--for he had no idea of their artifice,-and said to him, ' See, the patriarch has sent me his commands to depose thee from thy bishopric, and consecrate thee afresh.' And he, on hearing this, began lamenting and saying, ' $O$ heathens that ye are! lo, these many years have I been consecrated, and am a bishop, and, according to canonical order, three bishops took part thereat; and now, for what reason am I deposed contrary to the canon, and wickedly ordained anew? And if ye annul my priesthood, and ordain me afresh, then also first annul my baptism, and baptise me afresh.' And when they would not give way, but were even full of wrath at him, they took him tyrannically and violently and deposed him, and consecrated him afresh, while he smote upon his face, and his eyes became dim, and he grew blind. And so finally, in tears and lamentation over his state, and anxious only to hasten for 
refuge unto repentance, death overtook him, and his old age descended in affliction and misery to the grave, reserving his cause for that Judge who judgeth righteously.

II. 43. John further adds a copy of the recantation which they forced Paul to sign without reading it, and which is as follows;

Act of recantation, which the counsellors of John wrote in the name of Paul, and laid it before him.

"I, Paul, who was a lost and erring man, having come to the knowledge of the true faith, and repented, and returned to the Church of God of my own accord, and by my own free act, without violence or compulsion, acknowledge unto thee, my Lord John, the oecumenical patriarch, by this writing, that I consent, unto my last breath, unto the Synod of the six hundred and thirty holy fathers assembled in the city of Chalcedon, and to the letter of the holy and blessed pope of Rome, as the confession and faith of Peter, head of the Apostles; nor will I again turn away or change from it for ever. And these things I have confessed and signed in my own handwriting; I, Paul, bishop, confess that I consent, and receive all that is written in this paper."

This therefore they brought for him to sign, but would not let him read it, or know what they had written in his name, falsely and treacherously professing that it was all his own doing, and testifying of him a testimony of lies without fear of God. 
The patriarch's next victim was Elisha, who I. 15. already was in confinement in a monastery called Bethdios ${ }^{\mathrm{d}}$, whence the patriarch took him, and imprisoned him in his palace, and by the most rigorous measures compelled him to submit to his communion, Elisha hoping, says John, even so to find an opportunity of escaping from his hands. But on the patriarch's wishing to send him to Sardes, the metropolis of Lydia, that he might be deposed from his episcopal office, and consecrated afresh, Elisha resisted, saying, 'All unworthy though I be, yet was I made bishop by the orthodox, and thou never shalt consecrate me afresh. If however thou thinkest that it is according to order to depose me, and consecrate me afresh, depose me first of all from the baptism wherewith I was baptized, and then baptize me a second time.' To this the patriarch craftily replied, that, after all, it was but the vestments which he took away. But Elisha would not for one moment consent, or submit himself to him, or listen to his words: and upon this he grew angry, and imprisoned him in another monastery called Beth Abrahame, and

d This monastery was erected in Constantinople by Dios in the reign of Theodosius the Great, and was appropriated to monks of the order called Acœmeti, who flourished about this time. Du Fresne Const. Chr. iv. I 23.

e Bandurius, Imp. Orient. p. iii. 56 , says that ' the monastery, made without hands, was built by Constantine the Great, that he might put the monk Abraham there, whose name it subsequently took.' Among the signatures to the council of Constan- 
passed upon him a harsh sentence: and there accordingly he was detained for a long time, and underwent great affliction, until he fell seriously ill, when upon petition he was permitted to go to the warm baths attended by keepers.

I. 16. Far more severe and extraordinary was the treatment experienced by Stephan, bishop of Cyprus. He had aroused the wrath of the patriarch by warmly reproving him for seeking to annul the orthodox ordinations, and in return had been banished to the island of Platrea. Thither he now sent a body of clergy to fetch him away, and along with them a number of lifeguardsmen (excubitores), with orders to beat him with clubs ${ }^{\mathrm{f}}$, until he vomited blood, or consented to their communion. Twelve of them accordingly beat him until he fell down speechless in the midst, and lay apparently dead. But on seeing him lie motionless, and dying as it seemed, they ran, and brought four pails of water, which they dashed over him, and so after a long time his soul returned to him again, and he returned to life as from the dead. And thus by force he was compelled to submit to com-

tinople is Alexander, Archimandrite of the monastery of St. Abraham.

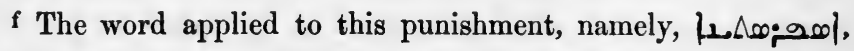
is evidently the corruption of some Greek perf. participle passive, and is construed with the verb to make. The sense requires that it should come from $\sigma \pi a \theta i \zeta \epsilon \nu$, fastigare, to beat with clubs, but by some process the $\theta$ has been changed into a $\rho$. The Olaf is as usual prefixed to a Greek word beginning with s. 
munion with them; but even so he was less influenced by his own sufferings, than by the knowledge that several of the believers who had sent to supply his wants, had been arrested and thrown into prison on his account, and that in case of further resistance on his part, they intended to attack them, and plunder their property. They took him thejefore, and brought him to the capital, where much discussion took place between him and the patriarch, but finally he was compelled to submit to their communion.

When however John required him to consent to the annulling of his orders, and his reconsecration to the bishopric of the island of Cyprus, he contended with him and resisted him, and finally made an outcry, and began to exclaim, -Woe is me! If thou purposest to depose me from the priesthood of the orthodox, and ordain me afresh, depose me first also from my baptism, and baptize me also afresh, and then thou shalt depose me from my priesthood and ordain me again. For by the life of the Lord God, if thou dost not baptize me afresh, I will never suffer thee to ordain me afresh.' And as this took place in the church, a great tumult arose, and multitudes flocked together, until Stephan rushed suddenly away, and entered the king's presence, terrifying him also, and exclaiming, 'Woe! woe! Christianity is ruined: the regulations of the Christian church are overthrown: all the constitutions and canons of the church of God are confounded and trampled under foot, and are 
undone! What means this wickedness, that contrary to law the priesthood of the orthodox Christians is annulled by those who are now in power, and another new one substituted in its place? For lo! these twenty years have I, unworthy though I be, been a bishop canonically consecrated by the orthodox at the command of 'Theodosius, patriarch of Alexandria; and now that I have yielded myself, and submitted to you, this man, acting in the same wicked way to me as he has done to many others, wishes to depose me also from the priesthood of the orthodox, and to ordain me afresh in his own. Let him show the canons where he learnt this; or say whether it is from ignorance and not understanding the canons of the church, that he thus acts; or whether, knowing them, he insults them and tramples them under foot, in his pride and haughtiness and wrong-headedness. If too this commandment proceeds from you, and he thus acts with your privity, let every one know it: but be well assured, that his purpose is, that after your reign is over, the blame and fault of breaking the canons shall rest upon you, and he intends that you should be included with him in the violation of the laws of the church. If moreover it is with your privity, and by your command, that he annuls our priesthood, and ordains afresh, command him also to annul our baptism and confer it afresh, and so let him proceed to reordain us as priests. For so the nineteenth canon of the three hundred and eighteen fathers commands, 
with reference to the pernicious heresy of Paul of Samosata, and the like, that they are first to be baptized again, and then such of them as are

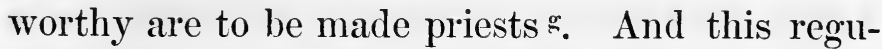
lation was made because of the wickedness of their heresy. Now then let this man show first of all what his pretext is for thus acting, and for being so puffed up with pride as to depose and ordain us afiesh.' When the king heard these things, and perceived that Stephan had good reason for finding fault, and was supported by the canons in his arguments, he was in a maze, and like one just roused from a deep sleep; and himself also blamed and reprobated the proceeding, saying, 'In very truth this is done wrongly and without law, and is contrary to the whole constitution of the church, for the priesthood to be annulled and conferred afresh; and it is monstrous and entirely foreign to all the constitutions of the church.' And then he commanded that such a thing should never again be done in the church

g The words of this canon are as follow : "As to such Paulianists as have subsequently fled for refuge to the Catholic church, the rule is, that they be all without exception baptized afresh. And if any previously were in the number of the clergy, if they were clearly free from blame and reproach, after being rebaptized, let them be ordained by the bishop of the Catholic church. But if on examination they be found unfit, they must be deposed. And the same rule must similarly be observed respecting deacons, and generally of all who are in the list of clergy. The deaconesses, as being so only in dress, and not receiving any ordination, we consider are to be reckoned entirely as belonging to the laity." Mansi ii. 678 . 
of God: and published immediately a royal edict forbidding every one from ever again venturing to annul the priesthood, except in case of the heresies in which the canons so ordain. And if, it proceeds, any bishops are proved guilty of so acting, they are to be immediately deprived of their sees and sent into exile. When however the edict was drawn up, and John knew that a decisive order was about to be published, he and his partisans contrived by bribery to put the obnoxious decree out of the way; and it was never again seen!

And there was great enmity between John and Stephan on this account all their days.

II. 3. In a subsequent part of the history, mention is again made of Stephan, where, after an outline of the previous narrative, our historian tells us, that this event led to much confidential intercourse between him and the king, who appointed him bishop of the island of Cyprus, and honoured him greatly, and also granted for his sake a considerable alleviation of the taxes there. It appears further that Stephan continued in union with the council of Chalcedon, the arguments employed being possibly too powerful for him to wish to experience them a second time, but used his influence on more than one occasion in mitigation of the treatment to which other monophysite bishops were exposed.

I. 17. The pretext, though, as the event proved, it was but a false and deceitful one, on which John and his counsellors summoned the bishops together. 
who had previously been exiled by him from their sees, and imprisoned in various monasteries, was, that he wished to confer with them as to the best mode of reconciling all parties, and establishing unity in the Church. On this pretence then he first took Paul the patriarch from the monastery of the Acœmeta ${ }^{\mathrm{h}}$, and imprisoned him in his palace, and then the rest, one after another, until all four were confined in the same prison, that is, Paul, and John (our author), and Stephan, and Elisha. No discussion, however, was permitted, but they sent them in the prison a paper containing words to this effect; 'You must unite yourselves to us after the maniner of the union be-

h These monks, whose name signifies " the sleepless," were so called because they were divided into courses, and maintained service day and night in their church. Although accused of following the heresy of Nestorius, they rapidly grew into importance, and possessed several monasteries in other parts of the empire, in addition to their great house at Constantinople, of which mention is frequently made by ec lesiastical writers. (Du Fresne, Const. Chris. IV. I5 I.) As regards Paul, whose name occupies so considerable a place in this history, he was consecrated patriarch of the Monophysites on the death of Sergius, (conf. p. I.), by the famous Jacob Zanzalus, to whom the sect owe so much that they finally adopted his name, and take their place in history as "the Jacobites ;" which again was shortened in Egypt by the Arabs to "Copts," the name by which the Monophysite Christians are there known. The bitter hatred felt towards him by the Alexandrians, his compulsory submission to the council of Chalcedon, the quarrel which thence issued with Jacob, his flight and concealment, and the strange circumstances of his death and burial, will be found fully detailed, and put into a new light, in the pages which follow. 
tween Cyril of Alexandria and John of Antioch.' Upon receiving this message, they both understood and despised the wickedness practised towards them, and sent in answer, "Ye have counselled well: and we therefore, provided we have leave to do and practise that which Cyril did, and may excommunicate and eject and drive out of the Church of God the Synod of Chalcedon just as Cyril did the wicked Nestorius;-upon these terms we will not oppose you upon other matters, but will unite ourselves to you without hindrance. If, however, it is not your pleasure to permit us to do that which Cyril did, how or in what manner craftily plan ye to require of us the union which finally took place between Cyril and John, when the very first step that Cyril took is forbidden us?'

Nor was this retort the sole rebuff which the patriarch had to endure from the Mono-

I. 18. physite bishops: for on a subsequent day, when they were brought into his presence to dispute concerning the faith, and the corruption of it by the council of Chalcedon, and concerning also his own proceedings, they took the initiative, and reproached him strongly, and argued with him, and rebuked him manfully, urging him with questions, and saying, ' $\mathrm{O}$ master, and chief ruler' of the church, shew us by what canon or ecclesiastical constitution you have been taught, and received the practice of annulling the ordination of the orthodox bishops, and the rest of the clergy, many of whom have been more years in 
orders than your father has lived : and yet nevertheless you depose and ordain them afresh in the priesthood of the two natures, the followers of which proclaim and teach a quaternity instead of the mysterious and holy Trinity? In what ecclesiastical constitution have you discovered, and lit upon this right of annulling the priesthood of the true orthodox, and creating afresh in its place another priesthood of the synodites? What is your pretext, or what fault find you in us, or what heresy, such as the canons enjoin, that you take and depose those, who themselves find fault with you, and flee from your communion because of the heresy of the two natures, and because of the blasphemies of the synod, and of the letter of Leo, which proclaim and teach a quaternity instead of the holy Trinity. You least of all men have the right, under pretext of heresy, to find fault with, and condemn them, and pronounce their ordination invalid. If, however, you think you have the right thus illegally to depose them, tell us wherein your right consists, and we will henceforward cease to blame you. For if you have persuaded yourself, that this practice of your's to depose true priests, and ordain them again, in violation of all the constitutions and canons of the church, is a right one, you should also have amnulled their baptism, and baptized them again, according to the purport of the canons. For the sixteenth (really the nineteenth) canon of the 318 fathers, which treats of the pernicious heresy of Paul of Samosata, or- 
dered them to be baptized afresh : and that then such as appeared worthy should be ordained priests again. If therefore you now consider in yourself, that you have received back from heresy those whom you have treated with as much cruelty as if they had been captives taken in battle, and ordained afresh, why have you observed one part of the canon, but set at nought its previous requirement?'

The patriarch listened in silence to these arguments, and knew that his acts were worthy of blame, nor had he any defence to offer for them : finally however he answered as follows; 'As I perceive that you are troubled and offended at this annulling of your orders,-for so I conclude firom what you have said, and to which I have given a patient audience,-if this matter is set right, and the annulling of your ordinations discontinued, will you be contented, and enter into union with me?' But they replied, 'What setting right is possible, after all this corruption and disorder which you have wrought contrary to law? Nor have your proceedings even been confined to your own diocese, nor limits put by you to your violence and heat and hatred, but you have extended even into other countries this your violation of law, and your opposition to all the constitutions and canons of the church: as regards which, one of two things must be the case, that either in ignorance of their injunctions, you have broken and transgressed them, and trampled them under foot, or, if acquainted with 
them, that you have despised and contemned them, and purposely set them at nought. But of this be well assured, that whenever the time shall come, whether in your lifetime, or, if so be, after your death, there will be a strict investigation, and canonical inquiry into all these transactions, if the world last so long, and the existence of the church of God. Moreover your last proceeding is a thing worthy of wonder, and a proverb, and the clapping of hands; whether it be the result of hasty passion, or of hatred, or of the pride of power; or whatever was the object for which you did it; do you settle this and decide it in your own mind, and whether it was an act fittingly done, and after careful examination; that after you had fallen upon your captives, as if they had been the spoil of war, or like a robber on his prey, and forced them to submit to communion with you; that then, after they had taken part with you in thirty-six consecrations of the Eucharist, and the liturgies during the whole feast of Passover as well as subsequently, and you had received them in right of their former ordination, and had made the presbyters sit with your presbyters in the chancel during all those days called the love feasts, and similarly had admitted the deacons to perform the office of the diaconate with the rest of your deacons, and had placed them according to their degree, that then finally, after all this, you ventured upon the annulling of their former ordination by some strange act of senseless audacity. 
But a point which we would now leave to your consideration and judgment is this, that in case you were determined, contrary to order and the canons of the church, thus to act, you should have done so before you had admitted them to officiate with you at the consecration of the Eucharist, and not, after all these communions, at which they had been present and taken part with you by right of their former priesthood, then to turn round, and depose them and ordain them afresh.' Much further was said on both sides, which from its copiousness and length we must omit; but it proved to him that his conduct was open to censure, and that, if he examined what he had done, he could not acquit himself of fault, especially in his last and most extraordinary act of annulling the orders of those whom he had himself admitted to officiate with him. Upon these points his silence plainly showed that he felt he was wrong, as he had nothing to answer but arguments of a most trifling and ummeaning character.

I. 19. As the followers of the synod perceived that their plans had so far failed, the victorious king Justin next undertook to frame an edict by which he hoped to bring about a union. And when he had carefully copied it out, he sent it direct to the bishops imprisoned in the patriarch's palace by the hand of Zachariah, a learned man', and chief physician of the palace,

i Literally "a sophist." His high position in the favour of Justin is shown by his having sent him to sue for peace fiom 
born at Arx Romanorum, and originally, as was generally supposed, of the orthodox persuasion. Him therefore the king sent with a copy of the edict, and a message to the following effect: 'The merciful king has sent you this edict, which he has had copied for your sakes, that ye by its means, together with the rest of your party, may be brought into union with us. And he permits, and even commands you, when ye have read it, to correct in it whatever ye see to be deficient and in need of correction : and whatsoever is deficient in it for a correct confession of faith, such as ye wish should prevail, add to it without fear.' The bishops accordingly having received this command took and read it, and saw that it was incomplete: for though there were expressions in it at variance with the council of Chalcedon, yet there were other's borrowed from it, and in defence of its views. In accordance therefore with the command they had received, they drew up heads, under which they arranged the corrections, which if their opponents would consent to admit into the edict, they were ready, they said, to unite themselves in the fullest manner with them. The same messenger then who had brought the edict took the amendments, but showed them first to his privy councillor and adviser John, and the rest of their confederacy, who upon hearing them were in fright and alarm, and great fear fell upon them. For

Kosrun after the calamitous capture of Dara. Bar. Heb. Chron. p. 89 . 
should the bishops succeed in obtaining the insertion of their corrections, they would tear up by its very roots the whole heresy of the two natures. And the strict Nestorians ${ }^{k}$ were even in greater alarm than those only half so; and agitated and made an uproar throughout the church, running to and fro, and stirring up both clergy and people, and saying, "If we accept these conditions, the whole church is thrown into confusion and overturned.' And finally their whole troop assembled together, and went to the king, and endeavoured to persuade him not to admit the corrections into the edict; and at the same time stirred up the members of the court to use their influence in their behalf, many of whom were not sound in their faith, and especially the quæstor, whose name was Anastasius, of Palestine, and who was not only an heathen, but a Samaritan.

When then they had entered the king's presence, and the corrections had been read to him, they pleased him greatly, and he gave orders for their admission into the edict, and that a fair copy should be written out. Upon which all present, clergy and laity, and the members of the senate, strove with him, saying, 'Depend upon it, my lord, that if you admit these corrections into

k Our author considers the whole of his opponents as really Nestorians, and adds therefore the epithet "strict" to indicate such as confessedly agreed with that heresy, whereas the council of Chalcedon, and consequently its regular followers, anathematized it. 
your edict, and these men enter the church, it will be forthwith overturned and ruined: and in seeking to recover and get back a few, you will make men leave the church in tens of thousands.' And when some of them grew vehement in their opposition, he became angry, and turned his face upon them, and said, "These chapters are right: but as for all of you, I know that you are Nestorians, and diseased in conscience, and rejoice not in a sound faith: and if you are not quiet, I will loose and bring out those bishops, and set them upon you, and make them fall upon you like wolves, nor will you be able to stand before them.' And then he commanded the quæstor to bring him before sunset twenty copies of the edict, with the corrections inserted; or, said he, 'I will take off your head!' And at this the agitation of the whole gang of Nestorians and semiNestorians grew extreme, and they buzzed about like a swarm of bees, and at length succeeded, partly by supplications and partly by terrifying him with the picture of the confusion it would introduce into the church, in prevailing upon him, after much importunity, to consent to leave the matter to their will; nor did they permit him to insert more than one or two trifling amendments: while, on their part, they introduced heretically into the body of the edict a rule to the effect, that the customs of the church were to be observed; which was a device, and crafty addition in favour of the synod, enjoining its procla- 
mation' 'in accordance with their custom. And by this they intended to render a union impossible, and trusted to make the wheel revolve in their favour as Nestorians.

I. 2o. Immediately that the edict thus amended was brought unto him written out fair, he signed one of the copies, and sent it to the bishops who were in prison, with a message, saying; 'See! now we have made a union upon the terms you require, and have sent you the edict, and you therefore cannot refuse to unite yourselves unto us; for it is for your sakes that I have composed this edict.' But the bishops, on reading it, saw that some fragments merely of the corrections which they had proposed were there, selected at the will of the other party, and therefore they rejected it, because their opponents had confused and mutilated it, according to their own fancy: and though they had not ventured, through fear of the king, to expunge those expressions of his which were opposed to the two natures, yet they had managed to insert in it so much of their own, that while some parts were against the synod, others were strongly in its favour, and plainly were borrowed from it and on its side. 'The answer, therefore, which the bishops gave to those who brought it was, that " if the stumbling-

1 The proclamation of the council of Chalcedon involved its acceptance as an ceumenical synod : but this was the very point at issue, the Monophysites regarding it as destitute of authority, and its decrees as invalid. 
block and source of the confusion of the whole church, the synod namely of Chalcedon, were entirely taken away, the church would stand in no need of the edict : but if it were to be proclaimed in the church, not a thousand such edicts, though fixed up in all parts and in every quarter, would bring about a unity, but produce rather schisms. For it is both opposed to the synod, and also contends in its behalf: and both sides of the argument are to be found in it.'

As they had thus rejected the terms proposed, I. 2 I. the patriarch threw upon them the odium of the continuance of the schism, and every day, in company with those sent unto them to represent the king's person, he protested, saying, 'See, it is you who prevent and hinder the unity of the church of God. For, after all our efforts for fifty years $^{\mathrm{m}}$, you are still driving it away, and resisting and grieving it, and not willing to come to any terms of peace.' But they in answer said, 'How do we prevent unity? A thing which you will not touch with one of your fingers, except so far as outside words go and trickery, that you may be supposed and imagined really by men to be in earnest after unity; and throw, if your devices succeed, all the blame upon us. And what is the unity you would make? or how can

$m$ Though the patriarch uses the term hifty years to express an indefinitely long period, yet it agrees closely enough with the commencement of Justinian's reign, in A. D. 519, from which time constant efforts were made to heal the breach occasioned by the council of Chalcedon. 
you expect us to come to terms with you, while you still retain the synod which has uprooted and troubled the whole church of God, and proclaim it, and love it? If, however, you are really anxious to bring about a unity according to your words, remove the snare and offence out of the level pathway of the faith, and eject it from God's church: and so, not we only, but all the believers, with joy, and free from all cause of stumbling, will unite ourselves to you.' And much more of the same sort was said, which we cannot detail because of the great thickness of paper which it would require; which passed between them every day in mutual discussion, but which, from the abundance of the words and the mass of writing, we have passed over and neglected, lest it should prove an annoyance to those who fall in with our history.

I. 22. But this was not all the bishops had to suffer, for they were also in disgrace with the chief laymen of their own party. For even before the persecution broke out, and the trials and distresses and imprisonments which it brought upon them, they were sharply reproached by other members of the orthodox party, who argued with them, saying, "Why do ye thus persist in dispute and obstinacy, and not make some compromise and give way a little, that there may be unity in the church of God? Why stand ye thus with stiff neck, and resist those who are in power, without having any care for us, whom ye are ruining with our sons and daughters and 
our substance? But what care ye that we lose our property, and become beggars?' And as these reproaches had even before been addressed to them by the orthodox, annoyed at the loss of their wealth, and as now moreover the synodites protested against them every day, saying, 'Ye are the persons who stand in the way of unity,' they fell into great grief, and spent both day and night in sorrow and bitter weeping, sitting over against one another in tears and wailing and sobs, and saying with sad words, "What then shall we do? for lo! we are blamed by both sides, and testified against, and found fault with : and while we are imprisoned here in misery, and no leave granted to any friend to see us, our opponents say and proclaim to the chiefs and nobles of our party, that they earnestly desire unity; and so we have to bear the whole blame of preventing unity, for every body will suppose that what they say is true. And thus we are exposed to the attacks of both sides, and shall be compelled to yield, and trust ourselves to the treacherous promises and false oaths of our opponents; though we know that they have no truth in them, and that they are unworthy of being the means of restoring unity. Should we however still resist them, we shall be held accursed of both sides even unto the end of the world, as the impeders and hinderers of the unity of the church of God, while they will have their false professions believed, and will gain the credit of being ready to effect a union, had not

D 2 
we repelled their efforts.' These, and such as these, says John, were the words they spake one to another during many days, with tears and groans; and he adds his protest, as in the presence of God, that his report of them is true, and himself present and an eyewitness of it all.

I. 23. The discussion lasted thirty-three days, during which they were ranged against one another in sharp dispute: those on the side of the synod being clad in all the pride of power, while those who dissented from it were shut up in prison, and bitterly oppressed. And whenever their presence was required, they were loosed and taken out of their prison, and brought into the patriarch's court ${ }^{n}$, where they were allowed to sit down, and the disputation began, and lasted as long as those in power permitted. For when either they were beaten in argument, or otherwise chose, the bishops were sent away, accompanied by their keepers, and were imprisoned within three sets of guards, the innermost being the bishop's own, the second consisting of men

n Literally "Secretum," but, as Du Cange shows in his notes, ad Alex. 269, 307, the name is applied by the Byzantine writers to the judicial courts. Among the ecclesiastical authorities, the treasurer had his court, in which he tried matters referring to the church revenues, and which was called Secretum œconomi ; in the Secretum sacellarii accusations were heard against the clergy and monks for dissolute living: while the patriarch had

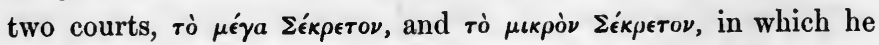
sat to discharge the public duties of his office Const. Christ. ii. 162 . 
belonging to the emperor's body-guard, while the third was the foreign guard, who kept the outer watch. Nor were they the only sufferers, for their confinement was shared by their dependents, and not merely by the clergy and monks and other freemen, but even by their slaves, all of whom without distinction were imprisoned in dark and bitter dungeons in the palace, and closely watched. Nor was this all, for they were stripped as bare as thieves could do it by the patriarch's body-guard and apparitors, who not only took from them their coats, but even trifles of no use to them, together with their shoes and girdles and belts; and in fact whatever was found upon them they took away, and left them upon the bare ground, with scarcely clothing to cover them, or food sufficient for their maintenance. Nor was any one allowed to visit them, or supply them with anything whatsoever either for their own wants, or for the use of the bishops. And instead of the promised unity, they and their friends had to bear all these evils and griefs and temptations; and the more so because they had plainly beaten in argument those who were thus torturing them.

Finally the bishops gave way: for on one oc- I. 24 . casion being summoned as usual into the patriarch's presence, they found not only John there sitting as president, but also some high officers sent to represent the king`s person, who sharply reproached them in his name for their obstinacy, saying, 'How long will ye thus resist and pre- 
vent the unity of the church of God, which our lord the king, and we also, are anxious to bring about, but which blessing you day by day prevent, and drive away? When will you cease thus to show plainly to all men that you are the disturbers of the church, and you alone? Now therefore, in short, either unite yourselves to us, or make it evident that it is you who trouble and disturb and hinder the unity of the church.' But the bishops in grief and deep sorrow said, 'Were matters justly tried, and by upright rules, it is not we who hinder union, but you, who, while the very centre of your heart is full of the corruption of opposition and division introduced at Chalcedon, wish to make it appear that we are the hinderers, while ye neither have proposed to yourselves, nor shown that you possess even the shadow of unity. What you fraudulently require is, that we should unite ourselves to all the falseness of Chalcedon, without seeking in the least to bring about in a just and upright manner a real union of the church. And now, as we have said from the beginning, if you wish really for unity, and your purpose is not rather to bring about a fraudulent deception and wicked artifice, put away first of all the cause of this division from between us, and at once unity is established in its place. Do not then falsely throw the blame upon us. And besides, supposing that this simple plan has never entered your minds, why, we ask, do you every day thus oppress and wrong us? why do you add 
to our anxieties pain and the misery of imprisonment, and the other wrongs which without fear of God you inflict upon us, while every day you further torture us with your words, and pierce thorns into our sores? Have you no fear of God, when you see that, lo! already our lives are consumed and spent and gone from the troubles which surround us on all sides? If therefore you really propose to make union, as your words declare, put away the council of Chalcedon, which has troubled and divided, and caused schism in the church, as you yourselves cannot deny, and so will a unity, free from all division, be established throughout the whole church of God.' And to this John and his assessors replied, 'It is you who prevent the ejection of the synod from the church: for if you united yourselves unto us, forthwith the synod also would be ejected, and the unity become complete.' To this the bishops answer, that they can conceive no other explanation of his conduct than the wish to make them accept the council of Chalcedon, ' of which be thou well assured, said they, and all besides, thatuntil the last breath cease from the nostrils of each one of us, the anathema of the synod and of Leo's letter, which conspire in dividing our Lord and God and Saviour into two natures after the union ${ }^{0}$, shall never

o These words contain the definition of the Monophysite creed, as appears from its frequent occurrence in our author, and in the works of Severus of Antioch, who in his letters, e. g. Lib. V. Ep. 54. says, "The Chalcedonians divide our one Lord and God, Jesus Christ, after the union into a duplicity of natures." (Add. MSS. Brit. Mus. I2, I81. f. 30.) They did not deny the exist- 
cease from our mouths.' But John and those with him answered, 'As we have often said before, so now, both we and our lords, their majesties, give you our word, and our oath as in the presence of God, that upon your union with us the synod shall immediately be put away: and whatever comes out of our mouths shall not be changed.' But still the bishops doubted, and said, 'If you really intend to do as you say, why do you not reject the synod at once, that not we alone, but all men without hindrance may join you? Plainly your object is rather to take us by subtlety, and make us accept the heresy of the two natures, and then afterwards you will turn round and laugh at us. If this however be really your purpose, be assured that you delude and deceive your own selves: for we know full well that your purposes and thoughts are not for unity, inasmuch as it is quite evident that what you say is not the truth, and that you pretend to be ready in words only, that we may be thought by every body to be the sole obstacles to union, and be anathematized both by you and all the world as the disturbers of the peace. Nevertheless, we will sacrifice ourselves for the sake of unity, for confiding in your words and promises, and acting as though already the synod were anathematized and ejected, we, with its anathema nevertheless incessantly in our mouths,

ence of the perfect godhead and the perfect manlood in Christ, but asserted that after their union, it was the very essence of Nestorianism to distinguish them. 
will communicate with you, once, or if so be, twice; but as for a third time, until the anathematizing and ejection of the synod has taken place, we will have neither part nor communion with you for ever and ever. For we know that you will not establish the truth of your words. But to make it plain and evident to all men that you are not prepared to make unity, but purpose to deceive us and all men, lo! we yield ourselves up to communion with you, as often as two times.' And much more was similarly said and protested on both sides, and so at length the bishops gave way, saying, 'Because of the slanders brought against us by the synodites, see, we yield ourselves up that it may be known that we are not those who prevent union.' For every body blamed them on both sides, saying, 'See, their majesties, and the patriarch are anxious, and in earnest and ready to make union, but those in prison prevent and hinder it.' And therefore they yielded themselves up with great sorrow, and anathematizing with loud voice the council of Chalcedon, submitted themselves to communion twice, as they had promised and agreed, after having strenuously demanded of the king and patriarch, with many adjurations during all those three and thirty days its anathematization and expulsion from the church.

The bishops apparently twice communicated with their opponents, and were let out of their prison: but upon pressing for the ejection of the 
synod, the patriarch and his council began, as our historian proceeds, to alter their words, and make excuses, saying; "We will write to the pope of Rome : and if he assents, we will eject the council: for we cannot for your sakes separate ourselves from Rome.' To which the bishops sadly replied: 'Now may we also repeat the Jon. iv. 2. word of the prophet Jonah, "Was not this my saying, when I was yet in my country?" But now at least it is known and made plain to all men, that not we in our prison, and in bitter misery, are the obstacles to unity, for which we have yielded ourselves up, but that those who are clad in power, and oppress us, have been false to their promises and oaths, and seek nevertheless to throw all the blame, not of this generation only, but of all future times, upon us, as though we hindered and prevented the unity of the whole church of God: but now men will say, "See, they have sacrificed themselves for it, though treachery has been used towards them."'

I. 25. But who can suffice to write or to detail the misery and grief and lamentation and breaking of heart, which came upon them after they had thus fallen into communion with their deceivers, and submitted to union with them, when union was never intended? For now their strength was spent and gone, and their eyes swollen and blinded with weeping and lamentation night and day; and scarcely might the grief of a woman for the husband of her youth be compared with theirs. For they could no longer eat their usual 
food, but remained fasting and without consolation, while their tears flowed unceasingly and unremittingly, and they sat with their faces covered, and bewailed with bitter cries and groans one unto another; and especially that now, after so many conflicts and imprisonments, and afflictions, they had thus been taken by false craft, and submitted themselves, and fallen, while all hope of unity was far away, and the promise made them unfulfilled. So sad was their state, that those who had deceived them now tried to comfort them, when they saw them thus consumed, and surviving only for grief, and said, ' Why do ye thus kill both body and soul, as if ye had sacrificed to idols? What have ye decreed against yourselves, that ye continue thus weeping and lamenting, and choking yourselves with grief? Take food, and be comforted, and live, and not die.' But though this and much more was said by their opponents, they refused to be comforted, and sat the rather in mourning and weeping; and after spending many days in indignation after they had been released from prison, they finally returned, and stood up manfully, and reproached them even more boldly than before, chiding and reviling them for their false and treacherous conduct; and so they were again delivered up to prison and to tortures even more severe than what they had previously endured: and at length were sent in bitter wrath each into separate exile.

Before their banishment however their anguish I. 26 . 
of mind had moved the pity of Justin and Sophia, who sent for them to the palace, and comforted them, saying; "Why do you give way to violent lamentation, till you are thus dejected, and more like men dead than alive? Cheer up, and be comforted: for we purpose in God to content you, and unite you to us in perfect unity. Do not despond.' But they argued with him at great length upon the promises made them, and which had been violated, and not put into execution : and finally he said to them, "As we are preparing to go to the hot-baths, wait for us for twenty or thirty days, and be assured, that we will return at once for your. sakes, and talk the matter over with you, and content you : and the whole church shall be one, and unite us all.' And so they were dismissed from his presence, after having detailed to him at great length their complaints.

I. 27. The king continued at the baths a full month, and then, according to his promise, set out upon his return. But before he had reached the city, while still on the other side of the straits at Chalcedon, the patriarch John, accompanied by his partisans, went out to meet him, and as it appeared, brought fresh accusations against his prisoners, saying, "These men have separated themselves from us, and withdrawn from the church entirely.' They now formed a plan for making trial of their determination, and deceiving them again: and drew up for this purpose a schedule of the chief cities, and sent it 
to them by the quastor, with this message; 'Inasmuch as we have a care for your peace, and are anxious for your honour, and wish to give you a share of authority, see, we have sent you a schedule of the cities of most note, not venturing of ourselves to name that over which you are to preside, but leaving it to your own will, that you may choose each one of you the city that best pleases himself.' And when the illustrious quæstor had received the schedule, and arrived at the city, he summoned the bishops, to place the schedule in their hands, and delivered them the message as above, with much beside as coming from the king. But they would not look at the schedule, nor receive it from him, saying, 'Tell the victorious king, that we did not sacrifice ourselves for the sake of being made bishops of cities, but in expectation that the promised unity would be fulfilled. For bishops we are, however unworthy. If then the promises of unity are fulfilled, and the oaths so repeatedly made us during so long a space of time, we are content. For relying upon them, and that our slanderers might not be confirmed in the assertion that we were the hinderers of unity, we yielded ourselves to communion with those who have acted falsely by us, and thought therein that they were deceiving us, whereas really they were deceiving themselves, and not us. And if now the synod is not ejected, according to their promises and oaths, and unity made, Heaven forbid that we should ever hold com- 
munion again with those who make mention of its name for ever and ever.' And upon their expressing this as their firm determination, and refusing to receive the schedule, the quastor grew angry, and went and told their words to the king; and he too was angry, and rose up in great wrath, and gave utterance to many threats against them, and stern denunciations; which also subsequently he executed.

I. 28. His first act was to summon the patriarch of the city, whom he accosted sternly, and with many contumelious expressions said, 'You are the man who have made the bishops turn back, after they had been prevailed upon with much labour and difficulty to promise to communicate with us: and you now have turned them back from us.' And in great excitement he commanded the senate to proceed to the patriarch's palace, and sit in judgment upon the matters in dispute, the patriarch also being upon his trial, and in case of their deciding that he was wrong, he said, that he would condemn him also.

I. 29. On the morrow then, in accordance with the king's command, the senate, accompanied by the quæestor, proceeded to the patriarch's palace, and the bishops were summoned to trial, and required, as a matter of command, to continue in communion with the partisans of the synod, keeping quiet, and not requiring any further concession. But they stood up, and strove powerfully and manfully in contest with them, and without fear openly convicted them of all 
their deceitful promises, and false oaths, and of the truth rejected by them, and trodden under foot; and after much besides they proceeded with great boldness to anathematize publicly to the senate the whole heresy of the two natures. And this they did stoutly as a thing of primary, and of secondary, and even of final importance: and also, by a sentence of entire separation, withdrew and separated themselves for ever from their communion. And much besides was done and said there in manly contest, until the wrath of the senators and of the patriarch blazed out upon the bishops, and they commanded that they should be dragged by the throat out of their presence, and separated from one another, and sent into exile. And the sentence was quickly put into execution, and they were taken away, and separated, and never saw one another more, being sent into banishment, some to monasteries, and some to islands in the sea, and some to oppressive and bitter imprisonment in hospices ${ }^{p}$, it being part of their sentence

p The $\xi \epsilon \nu 0 \delta 0 \chi \epsilon i a$, or hospices, were buildings erected in connection with monasteries, for the entertainment of strangers, and so important was this use in a country where inns were unknown, that the xenodochium was frequently the reason why the monastery was erected, or at least fixed its site. From their utility the emperor Julian ordered hospices to be erected in all the chief cities, and maintained by the state, Epist. XLIX. In the middle ages the name was frequently used as identical with monastery: and in the passes of Switzerland such hospices still exist, as that of St. Bernard, \&c. 
that they should be kept in confinement, and that neither friend nor stranger should be permitted to see any one of them. And much besides was decreed against them, cruelly, and sternly, and without mercy, in bitter anger, and with iniquitous violence, as though they had been murderers.

I. 3o. Now what has been here related and written may seem perhaps to those exercised in lofty knowledge, and acute in mind, and who judge things with nicety, to be but fiction, and a rhetorical composition merely of the writer, in words drawn from his imagination: for if not, 'whence,' they will say, 'had he the knowledge to enable him to narrate in this orderly manner, and describe and set down in writing all that was said by both parties; and that as if himself marshalled on one side, and aiming his shafts against the other, in combat for his own party?' Let then such as hold this opinion now know, that the writer of all these details was no stranger to the conflict, nor remote from the struggle, who, far away, upon report and by hearsay of others set down and described these events; but that he was one of those marshalled in the battle, and who, in earnest struggle equally with the rest, or even more so, manfully endured these sufferings, and patiently bore the pain of persecution and imprisonment: and let them know too, that not only the short summary contained in this book was spoken in argument with the king and patriarch, but a hundred times more 
besides, which however he has omitted, for fear of making the narrative too long, and crowding it with words without end. And though ranged on one side, that, namely, opposed to the two natures, as the narrative itself shows, he has observed a strict neutrality, avoiding all calumny and misrepresentation of those opposed to him, and the temptation of establishing his own views; and has endeavoured, in accordance with his promise at the beginning of the book, to be the advocate of truth alone, and has observed the seal of truth for both sides, in whatever was discussed, and brought forward and spoken, though confining himself to a summary of the facts, inasmuch as scarcely the hundredth part of what actually was said and done could, on account of its length, be set down in writing.

As the person whom our historian next mentions belonged to an obscure sect, who have left but few traces of their existence in the pages of ecclesiastical history, it may be necessary to give a slight sketch of Conon and the Condobaudites. A fruitful source of heresy in the fifth century arose from the careless statements of earlier writers, who, before theology grew up into a science, made use of language partially inconsistent with the technical exactness of later times: and as an almost idolatrous reverence was entertained for them, an attempt was often made to give to their indefinite statements a precise and scientific meaning. Thus, for instance, 
the Monophysites regarded Ignatius as a powerful witness in their favour, because he says, 'Permit me to be a disciple of the sufferings of my God :' and similarly, from the passages in which writers like Justin and Tertullian speak as if the Persons in the Holy Trinity differ in degree, Conon and the Condobaudites argued that there were as many natures, substances, and Godheads in the Trinity as there were persons. Timothy, presbyter of Constantinople, in his work ' On the Reception of Heretics,' (Meursii Var. Div. Lib. p. 123,) defines their doctrines thus, 'The Condobaudites are those who say that God is one in number, and not in an exactly similar equality : and they take their name from a building in Constantinople, in which they used to assemble.'

Their other name of Tritheites was given them because of their doctrine leading to the confession of three Gods. Not that they exactly said this, but rather that there was a quasi subordination in the persons of the Trinity, as earlier fathers seemed to teach. But this name was fatal to their progress, and injurious even to the Monophysites, out of whom they sprung: for Bar-Hebræus says that our author, John of Asia, complained of the disgrace brought upon them by their founder professing to belong to their party : and many even deserted them, and joined the Dyophysites, saying, that it was better to hold two natures, with the council of Chalcedon, than four Gods, with John Philoponus, the great exponent of their views. 
This Philoponus, called also John Grammaticus, a very learned Aristotelian of Alexandria, is generally looked upon as their founder, but really he only defended their heresy, by an argument deduced from an exposition of what 'substance' is, according to the doctrines of his great master, Aristotle. Their real founder was a certain obscure John Ascunages, whose creed is preserved by Bar-Hebræus: 'I acknowledge one nature of Christ the Incarnate Word, but in the Trinity I reckon the natures and substances and Godheads according to the number of the persons.'

But for the learning of Philoponus the sect would probably have expired with its founder; but an adventitious importance was further given to it by its being joined by Athanasius, the son of Theodora's daughter, whose great wealth was freely expended in obtaining converts. And as this made it necessary to expose its unsoundness, a public discussion was held under the presidency of the Synodite patriarch of Constantinople, with the proviso however, that none but Monophysite authorities, such as Severus of Antioch, should be quoted. The disputants against Conon and his party were our author, John of Asia, and Paul, subsequently patriarch of Antioch, one of the four bishops whose sufferings we have just read. The discussion lasted four days, and ended in the complete defeat of the Tritheite party. Another leading Monophysite who wrote against them was Theo- 
dosius, ex-patriarch of Alexandria. (Cf. Ass. B. 0 . ii. 328 etc.)

We may now, however, return to our author, whose narrative will be found to confirm the above statements of Bar-Hebræus, and which is as follows :

I. $3^{1}$. About this time Conon also was seized, who was at the head of the heresy of those who ventured upon enumerating the natures and substances and Godheads and Gods in the holy and consubstantial Trinity: and after his arrest, he too was imprisoned for a time with the rest in the patriarch's palace, and was required to sign a recantation as a heretic; but he resisted this, and would not. And when the victorious king learnt it, he swore by the Mother of God, saying; ' Though he consent, and go, and take the communion, yet if he make not a recantation, and express in it his penitence, I will not go and take the communion there.' Because then he was a heretic and a blasphemer, when about that time Photius, the son of Belisarius' wife, came to the capital, Conon was made over to him; and he took him with him to Palestine, and imprisoned him in the so-called New Monastery: where he remained three years, but was then set free, and went to Cilicia.

Their history is continued in the fifth book, and as it stands there quite unconnected with the rest, we propose to proceed with it here.

v. I. The great difficulty which they found in propa- 
gating their audacious and polluted heresy was the want of bishops. For at first there were but two, namely, Conon himself, the head of the schism, and Eugenius, both bishops of towns in Cilicia. When, however, their views became known there, they were greatly blamed by many of their compeers, and admonished: and upon their refusal to withdraw them, the sentence of deposition was passed upon them: upon which, they and Athanasius, the son of queen Theodora's daughter, who increased and multiplied the heresy by a liberal expenditure of gold, took measures in concert for obtaining a third bishop according to the canon; and for this purpose began honouring and flattering John of Ephesus, who was then resident at the capital, and had the administration of the entire revenues of all the congregations of believers there and elsewhere: their object being to prevail upon him by bribes and presents to submit to them, and join them, that so they might consecrate bishops. But he refused, and blamed them greatly, and proved to them by argument that 'they were heretics, and worse even than Arians and Macedonians and Nestorians, and all heresies besides.' And when they could not cajole him, and lead him astray, there happened just then to arrive at the capital a certain Theonas, who had been consecrated at the command of Theodosius the patriarch, but subsequently charged with some offence, and deposed. As having then nothing to do, he wandered about; and happening to arrive there, was 
easily induced by their gifts to adopt their error. Having associated him then with them, Conon and Eugenius consecrated numerous bishops, and sent them into all quarters to propagate their heresy.

V. 2. The episcopacy thus founded by Conon and Eugenius, the heads of the heresy of a multitude of Gods, was in fact contrary to the canons and constitutions of the church, as being given by a man who had been deposed from the episcopate; but nevertheless, whoever came in their way, whether young or old, unlearned or wise, and, so to speak, all their disciples and followers, whoever joined them, they made them all bishops, and sent them in all directions and to all countries, and so gathered congregations in Rome and Corinth and Athens and Africa, and led simpleminded people astray after them. They even made a serious attempt to lead astray the Patrician Narses at Rome, having taken with them for the purpose with no slight labour two picked men, the sons of one mother, named Phocas and Theodosius: but he turned his face away from them, and would not receive them. They managed, however, to lead into their error some of his chamberlains and chiefs and generals.

V. 3. Conon meanwhile, and Eugenius, had continued at the capital, even after they had been excommunicated, urging on their views, and arguing and deceiving people, and importuning them, and even going and complaining to the king that they were ill-used and slandered. Thereupon the king 
issued a command to the patriarch of the city to bid both sides assemble in his presence and that of his whole synod, that they might debate together upon the doctrines about which they were at enmity ${ }^{q}$, and of all of which an account is given us in the preceding books. And thus they acted; until Justin the king commenced a vigorous persecution, and sent them to Palestine into exile by the hands of Photius, Conon I mean, and Eugenius: while as for the other members of the party, they were far away, busied in traversing the regions of Syria and Cilicia and Isauria and Cappadocia, leading men into error, and ordaining priests and deacons in churches and monasteries, and cities and villages, until they even brought over whole districts to their views, and spread their heresy far and wide.

At Constantinople many still held to Conon for

V. 4 .

" This discussion is also meñtioned by Photius (Bibl. p. 5. ed. Bekker), who says that Conon and Eugenius opposed the vain labour of Philoponus respecting the resurrection, though they agreed with him in rejecting the synod of Chalcedon : but when, in a discussion held before the patriarch John, of which the acts were still extant, between Paul and Stephan on one side, and Conon and Eugenius on the other, they were required to anathematize John Philoponus; they not only refused to do so, but quoted passages from Severus and Theodosius in support of his views. They are, he adds, orthodox in holding a consubstantial and connatural Trinity, one God and one Godhead; but they blasphemously say, that the substances are divisible, and the Godheads and natures distinct, so as for there to be the Father, the Son, and the Holy Ghost. Bar-Heb., as we have seen, substitutes the name of John of Asia for Stephan. 
old association sake: for his house had been at the foot of the palace, and they used to go down in their court shoes ${ }^{r}$ and communicate in secret, and return and stand before the king without being found out. On this account, therefore, and because he showed himself to be an humble and righteous man, several of them joined in interceding for him, and he was set fiee, and departed from the monastery, in which he had been confined. The town to which he withdrew was called Eulæe, and there he abode in a numnery. And as all the people there, especially those of Cilicia and Isauria, were caught by his heresy, they ran after him, as though he had been one of the apostles, and glorified him, and adopted the error principally for his sake. Finally, however they severed into two parties, and opposed one another.

V. 5. An account of the error and schism into which these proclaimers of Gods fell, and the causes which led thereto, has been already briefly given in the preceding bookss, together with an enu-

r The campagi were shoes worn only by the emperors and the ehief officers of their court; and subsequently they were adopted by the pope of Rome; and George Metochita tells us that Michael Cerularius, patriarch of Constantinople, broke off communion with Rome beeause the pope would not let him wear 'a pair of scarlet campagi.' At the present day cardinals are also allowed to use them.

- To these lost books our author referred also a little above. John Grammaticus is the same as John Philoponus, the latter title being given him from his industry, the former from his profession. 
meration of the pernicious and mistaken writings of John Grammaticus of Alexandria, by which he first led them into error and imbued them with his views. For they all regarded them unanimously, and proclaimed them on all sides as though they had been a very gospel, and gloried in them. As then what took place in the intervening time comprises a considerable number of events, only one here and there can be recorded in our memorials, and the rest, on account of their mass, can neither be detailed nor related. When however the second treatise written by this John Grammaticus reached them, in which he teaches that it is not these same bodies which arise from the dead, but that they are changed into other bodies, which come in their stead to the resurrection, it led them into still greater error, and rent them into two heresies, each of which was, if possible, more abominable than the other. For some of them did not receive this second treatise, but opposed and reviled and anathematized it: while others regarded it as more precious than the writings of the prophets and apostles. And thus they quarrelled among themselves, and stood in mutual opposition, and were divided and separated, and excommunicated each other, and exposed one another's errors in written treatises. And still do the two heresies stand airayed over against one another.

In spite however of this schism, Conon and V. 6. Eugenius continued their efforts, and paid a visit to Pamphylia, in the hope of converting it to 
their views. This province had originally been occupied by the orthodox, and there are in it many large and noble towns, with churches, and numerous convents both of men and women. For long ago a portion of those named Acephalit, as having no head, separated themselves, and migrated in great numbers to this country: but by the zeal and earnestness of the orthodox there, they had all been converted, and returned to orthodoxy, and with one accord were animated with the spirit of the true faith. From that time, at frequent intervals, orthodox bishops were sent to visit them, and set in order all matters relating to the church, such as the consecration of altars, and new churches, and monasteries erected there. They also ordained numerous clergy, and attended to whatever else was neces-

t The Acephali were so called because they rejected the henoticon of the emperor Zeno (cf. Timothy, as quoted before); for so little did the early church distinguish between the province of the temporal and the spiritual power, that they received with complacency an edict of one of the most contemptible of the Greek emperors, published by him for a political purpose, and the object of which was to keep out of sight the synod of Chalcedon, and so put an end to the disputes which its decrees had occasioned. By anathematizing those who divided Christ, it satisfied most of the Monophysites, and by equally anathematizing those who confounded Him, it secured the approbation of the followers of the council of Chalcedon : and as it condemned all bishops who refused to sign it to degradation and exile, it was so generally received, that the few Monophysites who rejected it for not expressly anathematizing Chalcedon, were left without emperor or patriareh, and called therefore ' the headless.' 
sary. And twice, to our certain knowledge, this miserable Eugenius, who had now fallen into heresy, was sent there on these visitations; and again other. bishops at other times. Finally, however, the desire seized Conon and Eugenius of going to this country, and leading it into error, and winning it over to their heresy. But while thus busily occupied, the fated day arrived for Eugenius, and he died there; and Conon returned to Constantinople.

The cause which induced him to proceed thi- V. 7 . ther was as follows: previously to the schism among the Tritheites, and their separation into Cononites and Athanasians, the founder of the latter sect had made his will, and after naming the king and queen as his chief heirs, he directed that his slaves should be set free, and each one receive a legacy: he further left bequests to various friends, and to Conon a considerable sum of money to be expended on charitable objects, besides ten litres of gold for himself, to be paid immediately: and as we are told that a litre was equal to twelve ounces, the legacy amounted to about $£ 500$ : nor was this all; for he also gave him two litres as long as he lived, or about $£ 100$ a year; and in estimating the value of this, we must of course take into consideration the greater quantity of commodities which could be purchased for the same weight of gold. Having sealed this will, Athanasius deposited it in safe keeping at a time anterior to the breaking out of the schism: but 
when this took place, and they mutually excommunicated one another, and finally published books against one another, full of bitter revilings, Athanasius purposed to change his will, and exclude Conon from it, but died suddenly: and when his will was opened, Conon took what was written in it, while still excommunicating him who had left him the money. And this then was the reason why he came'to the capital. But on his arrival there, John of Asia, that is, John of Ephesus, sent him the following protestation: 'How long, $\mathrm{O}$ wise man, dost thou not take it into thy thought that thou art a mortal, and that thou must stand revealed before the dread tribunal of justice, and that there thou must give an account why thou permittest thyself to be called lord, and hast thy hands kissed by a sect of the church of the living God, who delivered Himself up for its sake? Why persistest thou in such folly, since thou must know that all, to whatever side they belong, whether it be thine or ours, are alike on their way to God? Let us both then, both thou and my unworthy self, while we continue in the body, abstain from all violence, of which Satan is the author, and be clothed in the gentleness and lowliness of Christ our God, and draw near to one another in mutual love, and put an end to this dispute and schism. And evilly as matters have gone in our days, and in our intercourse with one another, yet let us now, while we still survive, break down and destroy the 
wall of enmity between us, that false doctrine may not thus continue in the church of God.' To this Conon replied, that he should be glad if it could be so: but without giving any further answer, he took the gold that had been left him, and returned to Cilicia, where he delighted himself in his heresy, as much as a drunkard in his wine.

But though Conon was thus indifferent, it was V. 8. not so with the rest of those who proclaimed substances and natures in the Godhead; for being blamed by every body, and despised also by their own hearts, they often clad themselves in sheep's clothing, and begged that they might be reunited to the orthodox church: from which indeed they had gone out, but to which they had never belonged; for if they had been of it, they would have continued in it. Concealing therefore the guile of their hearts, they said that they wished to return to unity. But when they came to converse, and were required to repent, and cease from saying that there are substances and natures in the Trinity, lest thereby a diversity of Gods, and Godheads, such as the heathen hold, should enter into Christianity, they immediately declined, saying, "We cannot but affirm that the substances and natures are capable of being numbered.' To which the orthodox replied, 'that the faith of the church confesses one God, who is known under the three persons of Father, Son, and Holy Ghost: three persons: three names: one Godhead, and one substance: one nature: 
one Lordship, and might, and will, and kingdom, and authority, and dominion, in heaven and in earth: one three; and three one, without division and without confusion. How then can ye desire, though ye confess it not openly, to introduce into the catholic church, by these crowds of Gods, which like heathen ye hold, the doctrine of a diversity (number) of substances and natures, while in pretence, and not in truth, ye desire to be united to us, and guilefully devise and form plans for seducing and drawing aside the whole church to your heresy?' And so they were sent away blushing and ashamed; but their present failure did not prevent them from often making similar overtures, both at Constantinople and in other quarters of the empire.

V. 9. Especially both in Alexandria and Syria the same attempts were again and again made. For when they found that they could not cajole those at the metropolis, they proceeded to Alexandria,

, and drew up an act of recantation, in which they skilfully inserted their confession of faith, and presented it to Damianus ", the successor of Peter in the patriarchate there: but when he further required of them the denial of a plurality of natures and substances in the Godhead; and also, that they should excommunicate John Grammaticus and his three books, which had

u This Damianus was himself the founder of a sect called after him the Damianitæ. Their doctrine apparently distinguished God absolutely from God the Father, the Son, and the Holy Ghost, whence they are also called Tetratheites. 
been the original cause of their error, they showed that they were ready to anathematize the third book, which denied the resurrection of these bodies; but the first, in which was contained the doctrine of a diversity of Gods, they refused to reject and anathematize: and he therefore excommunicated and deposed them. They made the same attempt also more than once in Syria; but finally, when they saw that their wiles did not succeed, they continued without further attempts at union to hold their pernicious heresy even to this day.

Thus rejected by the orthodox in all parts of V. г. the empire, the Tritheites made an attempt to lessen the general odium in which they were held by forming a Catena, or literally, a large book of lacerations, which those of them who considered themselves to be philosophers tore from the living body of the writings of the holy fathers, in the idea that it established and confirmed their heresy. But of them the law of God speaks in its command, 'Ye shall Ex. xxii. not eat flesh torn by wild beasts;' for they tear 3I. dead limbs from the argumentative works of the holy fathers, imagining that they thereby prove that the fathers generally, like themselves, introduce and teach a plurality of substances, that is, of existences in the Godhead. But, without perceiving it, they only convict themselves thereby of teaching and proclaiming a plurality of Godheads and many Gods, as the heathen do. 
V. I . The further history of the Tritheites is given in few words; for these teachers of polytheism under Conon and Eugenius as their heads, flourished for a time greatly, and multiplied their bishops, and sent them in all directions to increase and establish their heresy, and posted also several in the capital, who opened there large meeting-houses, and gathered numerous congregations, to whom they taught their tenets boldly and without fear, because John, the patriarch of the city, was originally inclined to help them. But when, upon his death, Eutychius returned as his successor, he sent and seized all he could find of that portion of them, who separated themselves from the followers of his own favourite heresy ${ }^{x}$,- the denial of the resurrection of the body,-stripped their churches of their furniture, and overthrew and uprooted their altars: while their bishops and leading men he arrested and confined in various monasteries, where they were forced to remain in inactivity for many years.

v. г2. One alone recanted his errors and returned to the orthodox church, a Cilician bishop, consecrated by Conon, but whose name is not given, though he is said to have been a man of note.

$x$ This refers to what John asserts in ii. $3^{6,5}$, that Eutychius was a zealous follower of that portion of Philoponus' doctrine, which teaches that at the resurrection the bodies which rise are not these present bodies, but new ones in their stead. As Theodora's nephew adopted this tenet in opposition to Conon, its followers are known in church history as Athanasians. 
When, however, he knew and understood the false doctrine contained in their heresy, he turned from them, and offered to the orthodox a writing of recantation, and anathematized the Cononites, and their heresy, and was added to the side of the believers.

Elsewhere we have an incidental mention of them under the name of Condobaudites, a title, which, though frequently applied to the followers of Conon generally, seems properly to belong to a small section confined to Constantinople, where the monastery was situated, from which they took their name.

Their existence, it seems, was owing to their II. 45 . dislike of a sermon preached at the capital by Theodosius of Alexandria, against the two heresies of the Tritheites and the Sabellians, certain expressions of which offended them as appearing to imply that he also introduced a diversity of nature and substance into the Godhead. For this reason they withdrew and assembled apart, but they had no head, and no one to make priests for them: and therefore they often made the attempt to gain admission into the communion of the believers. Conferences accordingly took place, and such of them as had knowledge to discern what was fitting, united themselves unto them; and such as had no knowledge foolishly and without fitting reason wickedly continued as they were.

In his account of Conon, the Tritheite heresiarch, John mentioned that he was delivered into 
the hands of Photius, with instructions to imprison him in Palestine; and this induces our historian to give some details respecting this personage, who, individually worthless, is nevertheless deserving of interest on account of the ill treatment he experienced from his mother, Antonina, wife of 'the patrician Belisarius,' and the bosom friend and confidante of the unworthy

I. $3^{2}$. Theodora. Photius had been bred, he tells us, to the profession of arms, and had accompanied his stepfather in several campaigns; but, finally, for some reason, into which he does not enter, he had assumed the tonsure :, and the monkish dress, though he by no means conformed to their morals, but had put on the appearance of a monk under a borrowed name,-by which is meant, not that he concealed who he was, but that his adoption of the profession of a monk was but a pretence. And this soon led him to repent of the step he had taken; for shortly afterwards, being unable to quell the savageness of his temper, and bend it unto piety, he betook himself to the king, still clad outwardly in the monastic garb. Now it so happened that the Samaritans were in a state of revolt, and the king therefore sent him with full powers into Syria. As his wish then was to please men, and anger the God who made him, by running on every pretext after impure gains, he gave himself up to the spoiling and plundering and oppressing

y The tonsure, as I have shewn in my notes to Cyril, was at this date peculiar to monks. 
of mankind, till he became their uprooter and destroyer; and all the regions in the east, great and small, were ruined as utterly as if they had been pillaged by barbarians: and so great was the terror he inspired, that even the bishops and clergy of the cities fled from before him: for if he heard of any one whatsoever, either in the city or the country, possessing in sufficiency his daily bread, he seized them, and plundered them, and imprisoned them, and hung them up, and tortured them, and imposed upon them a fine of a pound of gold, whoever they might be, whether they were worth as much or not. Nor could he be induced to alter his sentence, even though a man had to sell himself and his children into slavery, and his household, and his substance. For when he layed hands on any one, whatsoever he said, Give me so many pounds of gold: for the king has need of gold to expend upon his wars. And in this way he gathered together hundreds of pounds of gold, and sent them to the king, in order that he might obtain authority and power from him to do whatever he liked to whomsoever he liked, and that no man might stand before him. For he even exacted large sums from bishops; and if any one resisted him, forthwith on the very spot he strung him up to a rope fixed either behind his head, or to his elbows, or to one arm. And in this way, it is said, he served the bishop of Askalon, on whom he levied a contribution of three hundred pounds of gold: and when the bishop bewailed, and 
begged for mercy, saying he had not so much, he ordered him to be hung up by a rope, and left him hanging, and went on his way, leaving orders that though he should hang for three days, they should not let him down till the money was paid. Nor was he loosed from the rope till the three hundred pounds of gold were brought. And he treated the rest in many instances in a similar manner, till the land trembled before him, and all the magistrates and governors and the rest of the lords. And when many went to the king, and in his presence implored for mercy, he wrote to Photius, saying, 'The money you'send us being got by plunder is a sin ;' but he wrote in reply, ' Do not you be afraid, my lord, of sin, in respect of the gold which I send you : the sin is on my head.'

In these doings he was accompanied by a crowd of monks fit for such deeds, and members even of the imperial family, and officers of the household troops, and guardsmen, and a host of Romansz. And when in this base course

z The spatharii were the emperor's bodyguard, so called from the $\sigma \pi \dot{a} \theta \eta$ or broadsword which they wore. By Romans are meant the inhabitants of Constantinople, who had so appropriated this name that the modern Greek language is to this day called Romaic, and the country about Constantinople Roumelia.

The $\delta \epsilon \sigma \pi о \tau \iota к о$ were members of the imperial family. The later emperors often even called themselves 'despot' upon their coins.

The domestici were the emperor's household troops, to whom was intrusted the charge of his person: and as they were generally selected for the command of other troops, the word dome- 
of destruction and wickedness and cruelty, devoid of all fear of God, he had fulfilled a period of twelve years, his alloted time overtook him, and he descended to the tomb by a miserable end, and with an accursed remembrance. And there was appointed in his stead a certain Abraham, the abbot of what is called the new monastery in Jerusalem.

Returning from this digression, our historian I. 33 . proceeds with some further particulars respecting the persecution, and says, that in the midst of it a missive was sent to Alexandria, the chief seat of the orthodox, requiring the presence of certain of their learned men and jurists, or, as they were then called, sophists and scholastics, and with them many others, including some of their great shipowners, the most powerful class in that wealthy city. Their secret purpose in requiring their presence was to compel them to communicate with the synod, but their pretext was the wish to consult how they might best restore the unity of the church. And in fact they did treat with them in both ways, but finally required them to communicate. But they refused, and resisted for many days, or rather for a whole year, manfully, nor would they give way or sub-

sticus became equal to captain, just as the comites or immediate attendant of the kings in the middle ages became high officers, 'counts.' It was also the title of an ecclesiastical dignitary, whose business was to preside over the chanting in church-in modern phrase, a precentor. 
mit in the least. And, finally, they were let go, because those in authority were afraid to proceed to acts of open violence, as the capital depended upon Alexandria for its supplies of wheat. A few, however, of them were detained for a period of three years, but when they proved inflexible, all alike were set free.

I. 34. The heads, however, of the orthodox clergy at Alexandria were soon afterwards arrested and sent to the capital on a different charge : for information being sent to the king that the bishops there, upon the death of the blessed Theodosius, had consecrated, not one bishop in his stead, but two, he was highly displeased, and ordered the arrest of all their leading men, and that they should be sent to him,-and this was also done, for they were arrested and conducted thither, and detained for about a year, until the patriarch John died, and was succeeded by Eutychius, who had occupied the throne before him, and who immediately upon his arrival dismissed them to their homes ${ }^{\text {a }}$.

I. 35. But besides these some pious Egyptians were also summoned to the capital to search into future things. For again and again they sent to Egypt to bring from thence certain hermits who had the reputation of knowing secrets, and

a The fourth book of John's history, from the thirteenth chapter to the end, is chiefly occupied with the detail of the disastrous consequences to the whole Monophysite party of the consecration there by different factions of two opposing bishops, Theodore and Peter. 
of understanding things future; as for instance, how many years the king and queen would live, and who would be his successor; and other things of the same sort. And some of them, when required to prophecy these things, refused, and confessed that they knew nothing about them: but they spake of correction and judgment and righteousness, and that the doing of these things pleases God, and brings men near unto Him. Such, then, as would not consent disgracefully to give an answer as men-pleasers, according as they were required, were immediately sent away and driven from the city to go to their own land: while those who, through desire of human applause, yielded themselves to the task of discerning the secrets of future time were held in honour, and lived in ease and luxury, with their wants supplied from the royal table. And this was done, not once only, but again and again.

But to return now to the main thread of the

I. 36 . narrative; although the monasteries, as has been mentioned above, were treated with lawless violence, yet but few of the members had submitted to communion with the patriarch, and the rest had been expelled, and sent to other monasteries, while clergy were everywhere introduced in their stead, to celebrate the holy communion, and administer it to those who had yielded to him. The name, moreover, of the synod was written up, and proclaimed in them, and the pictures of all the orthodox fathers taken down, and those 
of John himself every where set up. But as he had done, so was he requited of God. For after his bitter and painful death, and the succession of Eutychius his predecessor upon the throne, his pictures in all places were utterly destroyed, and those of Eutychius fixed up in the churches in their stead. Most also of the nunneries returned to their old creed, and became orthodox, except a few young girls, who still went every day and received the sacrament from the clergy in communion with the synod, and assumed the monastic dress : but the rest openly seceded, and not a single one of them would take the communion at their hands, especially after the death of John.

I. 37. And even before his death, John, still intoxicated with wrathful zeal for the persecution of Christians, and thirsting, like a wolf, for the blood of the lambs, went into the presence of the peaceful and serene Cesar ${ }^{b}$ Tiberius, being anxious to inflame him also with the same angry zeal as himself. But after he had exhausted his arguments against the believers, the Cesar replied, 'Tell me now the truth: who are these persons about whom you ask me, and whom you urge me to persecute? are they heathens?' The patriarch, knowing that deceit was

b The title Cesar at this period of the Byzantine empire signified the successor designate to the throne: and he was usually addressed by the epithets of "serene," and "peaceful," just as the emperor was always "victorious," the patriarch "merciful," and so on. 
impossible, answered, 'Heathens they are not.' 'What then,' said he, 'are they heretics?' 'No, my lord,' he replied, 'neither are they heretics.' 'Well then,' said he, 'as you yourself bear witness, they are Christians.' 'They are so indeed,' he replied, 'Christians of the Christians.' 'If then, as you bear witness,' said the Cesar, 'they are Christians, why do you urge me to persecute Christians, as if I were a Diocletian, or one of those old heathen kings? Go, sit in thy church, and be quiet, and do not trouble me again with such things'.' And so the heat of his savageness cooled down, until the wrath of Heaven overtook him, as we have mentioned above, and he departed from this life. And when his successor, Eutychius, returned to his throne, being incited by those clergy who had become habituated to plunder and rapine, he also had an audience with 'the serene Tiberius Constantinus Cesar,' and spake much against the whole party of the believers. But he gave him also for answer; 'We have enough to do with the wars against the barbarians, which surround us on every side: -we cannot stir up another war against Christians. Go and sit quiet. If however, by word and admonition, you can persuade them, do so: but if not, let them alone, and do not persecute

c This story is related again in B. iii. $\mathbf{2} 2$, with the addition, that 'Tiberius said to the patriarch, "Now on your oath," and that though John was a great hypocrite, he would not venture on oath to tell a falsehood. 
them, nor trouble me, who am exposed to the attacks of war from every quarter.' And so he also was rebuffed for the present, and kept quiet.

I. 38. But even while John lived, the orthodox congregations grew in strength, and lifted up their heads again. For though he had driven away their inmates, and closed their doors, yet when God sent down upon him from heaven the chastisement of his heavy wrath, they all began to take courage, and reopened them : at first indeed timidly, and quietly, and little by little, and so even during his lifetime they obtained considerable additions to their number, and multiplied. But when he was scourged by the wrath of God, and his mind enwrapped in the deadly fire which was fixed in his heart and burning in his bowels, the orthodox acted more boldly; and finally, his adherents and the ministers of his wickedness, as if knowing his will, went unto him, and said, 'Lo! once again these enemies of the church and synod have opened the doors of their meeting-houses, and are spreading more than ever, and rejoice in thy sickness, and pray for thy death. But if thou wilt give us the command, we will torture them more sharply than at the first, and heap evils upon them.' But he in wrath, and with loud voice, resisted them, saying, 'Depart from me, ye murderers, and be content with my humiliation; for it is ye who have chiefly brought me to this miserable state. There are curses enough already uttered, which 
have roused and brought down upon me the wrath of Heaven. Away with you, and let no man ever mention this subject again in my presence.' And so they departed humbled from before him. And thus then, as we have said, both before his death, which was not long delayed, and after his death, the congregations of the believers once again met in full security.

One monastery ${ }^{d}$, the history of which deserves especial mention, was built by the famous eunuch Narses, when holding the office of chartulary at the court of Justinian, before he was sent to restore the fortunes of the empire in Italy. His purpose had been to retire from the palace, and adopt the monkish tonsure, and reside in it; and with this object he located there the monks who had been driven out of Cappadocia by persecution, and purchased a large estate, upon which he erected a magnificent church, and a hospice for the reception of strangers, and finally, endowed the monastery with large revenues. But just then he received orders to proceed to Rome : and there, by the help of God which went with him, he gained numerous and important victories in many successive campaigns. And there finally he departed from this world, and his bones were brought and deposited in his monastery, in the presence of the king and queen,

d This monastery is mentioned in the Chronographia of Theodosius Melitenus, p. 95. edidit Tafel, thus,

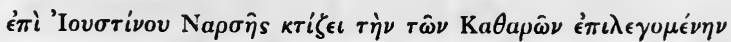

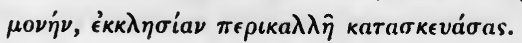


who took part in the procession, and deposition of the relics, and in his canonization as founder.

II. ${ }_{4}$. In a subsequent part of the history, we have some further particulars respecting these Cappadocian monks, who found but a temporary resting place in Narses' monastery. When he took pity upon them, they had just, in the height of the persecution in Justinian's time, been expelled from a large and well built convent belonging to them in Cappadocia, the name of which was Gordison, and were no less than seventy in number, men aged, honourable and zealous. And compelled to wander from place to place, they erected buildings, and tried to establish themselves, but were repeatedly driven away, until finally they lit upon a good and fertile piece of ground, replete with every thing essential for their maintenance, at Cardynias, near the warm baths of Dephatia, upon the straits to the south of Constantinople. This one of the king's chamberlains, who was a believer, purchased for them, and they settled there, and planted a vineyard, and built a large church. In process of time the whole band of venerable elders slept in their graves, and young men alone remained: and finally, when king Justin, attended by the queen and the whole senate, were on their way to the warm baths, they sought admittance and lodged in this monastery; and by promises and gifts prevailed upon them to submit themselves, having commanded both that their former monastery, from which they had been originally driven by perse- 
cution, should be restored to them, and also granted them a remission of taxes. And thus they brought them to submission, and imbued them with their errors, after they had struggled for a period of twenty years under the miseries of persecution. And now they were divided, for part returned and took possession of their former monastery, and part stayed where they were. And they were confused and troubled : for their ship, so to speak, was wrecked at the very mouth of the haven, by their complete perversion from the orthodox faith.

The rest of the first book is occupied with some details respecting the episcopal succession in the three great patriarchates of Alexandria, Antioch, and Constantinople, as follows:

As regards the synodite bishops at Alexandria, I. 40. after John, who had originally been a patrician at the capital, but was sent there, had fulfilled his years and died, there came as his successor one Eulogius, the head of a hospice at Antioch, who was made pope there in the third year of the victorious Tiberius. And of the Julianist party Dorotheus was bishop, and occupied the see for many years. And of the followers of Theodosius (that is, the Monophysites) after his death, first of all a Syrian was created bishop, named Theodore, the governor of a monastery. But when the clergy and others learnt of his appointment, they turned away, and having refused in violation of canonical order to 
receive him, they took the haughty resolution of consecrating another besides, whose name was Peter; and when he had fulfilled his time and consecrated more than eighty bishops, he died. and they elected in his stead a Syrian, named Damianus, and continued in a state of schisme.

I. 41. At Antioch the Great, in Syria, Flavianus was patriarch in the days of king Anastasius, but being convicted of the heresy of the two natures, he was deposed from his throne, after occupying it certain years. His successor was the orthodox Severus, who held the see six years; but at the

e Of John, Le Quien (Or. Ch. ii. 438) knows nothing more than that his consecration at Constantinople instead of Alexandria gave great offence, as an invasion of the rights of the latter see, and that after an episcopate of eleven years he died A. D. 578 , or 579. Eulogius succeeded, he says, in the second year of Tiberius, but, according to our author, the third. To him Gregory the Great addressed his epistle against the claim of the Constantinopolitan patriarchs to the title of universal bishop, and the frequent mention of him in the Bibliotheca of Photius, attests the important position he held in the East. The Julianistæ took their name from Julianus of Halicarnassus, who argued that the body of our Lord not merely did not see corruption, but was incapable of it: and the character of the times and place may be judged from the fact, that having agreed on having a bishop in common with the Theodosians, but imagining that they were not fairly used in the selection of an abbot named John, they seized the unfortunate man, and flayed not his beard only, but the skin of the whole lower part of his face. Le Quien argues, that Dorotheus was bishop, not of the Julianists, but of the Theodosians, but the testimonies he quotes all agree with our author. Theodore was unknown to Le Quien, and his acquaintance with Peter and Damianus was also very slight. 
commencement of the reign of Justin I., he was expelled, and after spending some years in the Egyptian desert, he died there. For a year Antioch had no bishop, but finally there came down Paul the Jew, who had been dean of the church of St. Euphemia at Chalcedon. He took down the diptych on which was inscribed the name of the synod of the East ${ }^{f}$, but after occupying the see two years, he was proved to be a Nestorian, and was also ejected and expelled. And in his place came Euphrasius, a Samaritan, in whose seventh year Antioch was overthrown by an earthquake, in which he lost his life. And after him was Ephraim of Amid, the son of Appianus, a worse persecutor than either Paul or Euphrasius, and after certain years he died. And his successor was Domninus, a Roman, who was followed by Anastasius, who had held the office of Apocrisiarius at Alexandria : but accusations were laid against him before Justin II., who deposed him, and sent in his stead the abbot of the monastery of Mount Sinai, whose name was Gregory.

And on the part of those opposed to the synod

f The Chronicle of Edessa, Ass. B. O. I. 408, says, ' By the providence and care of the God-loving king Justinian, the four holy synods had their names inscribed on the diptych of the church, to wit, the names of Nicæa, Constantinople, Ephesus, and Chalcedon.' That of Ephesus is here meant by the synod of the East, which was generally distasteful to all persons of Nestorian tendencies. 


\section{of Chalcedong, first of all, after a long time had}

g Flavianus, after a thirteen years' episcopate, was ejected by a provincial council in A. D. 5 I2, for not condemning with sufficient readiness the council of Chalcedon, as they considered that his anathema of it was wrung from him. The expulsion of his successor, Severus, was the first act of Justin I., a determined upholder of the Chalcedonian tenets, and took place in A.D. 5 I 7 : how long he lived afterwards is uncertain, but he was alive and at Constantinople in A. D. 536. His deposition was followed by long discussions, so that no successor was appointed till early in A. D. 519, when Paul came to Antioch with special directions from Rome that he was to be consecrated in his own see. Having however taken a strong course against the Monophysites, he was compelled to withdraw in A. D. $5^{21}$. His successor, Euphrasius, is said by Evagrius to have been a Jew, and Theophanes says that first of all he expunged the name of the synod of Chalcedon from the diptych, and that of the pope of Rome: but finally repented, and proved his sincerity, as Malalas testifies, by putting many of the so called orthodox to death. Ephraim was originally Comes Orientis, but his care of the people of Antioch in the distress occasioned by the earthquake, made them vehemently desire him to take orders, and be their bishop. He held the see eighteen years, and an account of his writings in defence of the council of Chalcedon may be seen in Photius Bib. cc. 227, 228. Domuus, or Domninus, was bishop from A. D. 545 to A. D. 559. Anastasius is famous for his bold resistance to Justinian, who had asked his opinion about his favourite theory of our Lord's body being incorruptible. His deposition in A. D. 569 is said to have been caused by his answer to the question, sent to him from Constantinople, why he so squandered the revenues of his see? 'That Justin may not plunder them,' he replied, 'who is the ruin of the whole world.' But others ascribe it to his resistance to the attempts made by John Scholasticus to claim the right of consecrating the other patriarchs, as in the case of John the Patrician mentioned above. Of Gregory, who held the patri- 
elapsed, they consecrated in the place of Severus, one Sergius, a man sprung from the town of Tela, and after fulfilling three years, he died at the capital, where he chanced to be. And again after an interval Paul was appointed as his successor, an Alexandrian, and Syncellus of Theodosius of Alexandria; but who, as regards his government and fame, fell upon evil days: for by reason of the schism which took place between him and the blessed Jacob, the church of the believers was split into two parts, and both sides entered upon unappeasable wars and contentions one with the other. And the opponents of Paul, after Jacol's death, set up, contrary to law, another patriarch at Antioch, named Peter,

archate from A. D. 569 to A. D. 593 , and whose business talents caused him to be repeatedly employed by the Roman emperors on the most important transactions in the East, very extraordinary revelations are made by our author, whether they are true or false. His own friends extol him for three things-his bounty in almsgiving, the readiness with which he forgave injuries, and the copiousness of his tears. Le Quien ii. 729-736.

Of the Jacobite patriarchs, Bar-Hebræus names Sergius as the immediate successor of Severus, and says he was a monk in a monastery near Tela, or Constantina in Osrhoene. After an episcopate of three years he died, and the history of his successors, Paul the Black, and Peter of Callinicus, is so fully given by our author, that any further details are unnecessary. The patriarchate thus commenced has continued to the present time, and Le Quien gives the history of no less than 80 persons, who up to A. D. I721 had held in regular succession the oversight of the Monophysites in the East. 
of the city of Callinicus. Such then were the events which followed in rapid succession, up to the time when these things were written, and which is the year eight bundred and ninety-two (A. D. 581).

I. 42. At Constantinople during the reign of Justinian, on the death of Epiphanius, Anthimus was translated to the patriarchate, having previously been bishop of Trapezuntium. And after holding the see a year, on Severus of Antioch being summoned from Egypt by the command of Justinian, that they might confer upon the means of unity, and Anthimus had learnt by the arguments of Severus the unsoundness and erroneousness of the synod of Chalcedon, and the blasphemies of Leo in his letter, he left the throne of the capital, and withdrew and united himself to Severus and Theodosius of Alexandria. And after him the metropolitan see was occupied by a certain Mennas, who had been the warden of Sampson's hospital. And when he had fulfilled his years, he left this world: and in his stead arose a young monk, who was Apocrisiarius of Amasea, and when he had occupied the throne about twelve years, he was deposed and ejected, and John, a Syrian, of Sirimis, a village in the territory of Antioch, succeeded him. And upon his appointment he pronounced sentence of deposition against Eutychius, and Eutychius pronounced a similar sentence against him. And after John had fulfilled twelve years and a half, he died: 
and Eutychius was summoned again, and returned to his throne ${ }^{h}$.

h Epiphanius succeeded John the Cappadocian A. D. 520, and after a patriarchate of fifteen years died in 535. Anthimus his successor was appointed by the influence of Theodora, but as Marcellinus tells us (ap. Le Quien, Or. Chris. i. 223) he was expelled by a synod summoned by Agapetus, pope of Rome, for having deserted his original diocese, an act called, in the theological language of the times, adultery. Evagrius however, iv. I I, confirms the statements of our author. Mennas held the patriarchate from A. D. $53^{6}$ to A.D. $55^{2}$. The hospital, of which he was previously warden, was built at Constantinople by Sampson, for the relief of the sick and poor, and rebuilt, enlarged, and amply endowed by Justinian. His successor, Eutychius, is commemorated in the Greek church as a saint, and his life, written by his syncellus Eustathius, is still extant. He died in A. D. 582 , but John Scholasticus occupied the throne for twelve years and a half of his patriarchate, from A. D. $5^{6} 4$ to A. D. 577 .

End of the First Book of the Narratives of the Church, in which are contained fortytwo chapters. 


\section{BOOK THE SECOND.}

AT the commencement of the Second Book, John returns to his main subject, and, by way of introduction, repeats his account of the great grief of the bishops, when they found they had been deceived, and the determination to which they came of immediately breaking off all further communion with the patriarch. His words are

II. r. as follow: To return then to the narrative of the bishops, and the many trials and three separate imprisonments, and other things which they had to endure, and of which we have given a short account in the First Book, as was fitting there according to the order of the arrangement; directly they saw that they had been deceived, and that the many promises and repeated oaths made to them, to the effect that unity should be fully established, had been broken, having been thus induced by fraud twice to communicate, they were in sorrow and mourning and trouble without end, and in lamentation and bitter sighs, and finally determined and made up their minds, that never again should there be communion with them and the followers of the two natures for ever, even though they dragged them to death by the sword or fire. And on this account violent anger and great wrath was felt against them, and they were all sent into 
exile for the third time, each one of them separately; so that now quickly they were removed far away from one another, and severe and bitter sentences passed upon them, and great was their distress in being thus separated and banished far away from their friends and relatives, and that, as the sentence ran, even until their deaths.

Upon the bishops coming to this firm and II. 2 . mutual resolve, and determining and deciding, that never again would they communicate with the synodites for ever; and when further they resisted and stood up manfully against those in power, and much beyond recounting had been done and spoken on both sides, in great conflict and struggle, sentence of exile was finally in bitter gall decreed against them, each individually, without mercy. And first of all, Paul the patriarch was removed to the monastery of Abraham, and confined there. But while shut up he found a place where a scanty light entered his prison, and began in secret to write an account of what had been done in the church by John of Sirmin: but being watched, he was caught in the act of writing, and the book taken from him before it was finished. And they carried it to John, who took it in bitter wrath, and went and read it before the king; and when on hearing it he found that his own acts against the orthodox were regarded with disapproval, as well as those of the patriarch, he too was greatly enraged and embittered against Paul, and commanded that they should 
take the book and lay it before Paul, and require him to confess whether he were the author: and should he do so, they were to make him write an acknowledgment with his own hand to that effect. On the other hand, should he refuse, they were to scourge him to the point of death, until he confessed, and then commit him again to his prison. The officers accordingly took the book to the monastery, and with great anger showed it him, and required him to confess in writing that he was its author. And he, as falsehood was useless, confessed that he wrote it, and upon their requisition made with his own hand the following acknowledgement, 'I Paul confess that with my own hand I wrote all these things which are in this book.' Upon which, leaving him in prison, they carried the book back to the king and the patriarch. And so great was their indignation, that they threatened Paul with death; and the more so, upon finding that he had embodied in it accusations also against Rome. And both Paul himself, and all men, were alarmed for his life, and expected that he would die a painful death, and perish from this present life.

II. 3. Stephan ${ }^{\text {a }}$, however, bishop of Cyprus, was then

a As no attempt is made by John of Ephesus to arrange his Narratives in chronological order, I imagine that it was subsequently to the banishment of the four bishops, that the patriarch had convinced Steplian of the soundness of the council of Chalcedon, by the extraordinary arguments recorded in c. 16 , and as he still continued in communion with Chalcedon, though refusing 
in great honour with the king, and boldly ventured to offer a petition in Paul's behalf, praying that he might be pardoned for his sake, and set free from the terrible misery in which he was confined. And the king accepted his intercession, and promised that if he would come to the capital, and take the communion in his company, all his offences should be forgiven him. Stephan therefore went to him, and after conversing with him, induced him by the terrors of death to yield himself up, and accordingly he came and communicated, and was taken into the patriarch's palace. And John, wishing to make sport of him before all men, assembled a large number of the senators, and certain also of the inhabitants of Alexandria, to which city Paul belonged ${ }^{b}$, and made him receive the sacrament from his hands afresh, in the presence of them all, that even though he should wish afterwards to return, it might be, as he supposed, impossible. From this time the king every

to be reconsecrated, and was supported in this by Justin, he was now dwelling at Constantinople in full possession of the influence which, as our author mentions above, he obtained over the weak mind of the king.

b. So Dionysius, in his Chronicle, quoted by Ass. B. O. ii. 6. ' Paul who had been consecrated patriarch of Antioch, by Jacob Burdoho, was by birth of Alexandria; and having partaken of the communion with John the Chalcedonian, for the sake of peace, he was deposed and ejected; and further, because he had secretly consecrated a patriarch of Alexandria ;' (of which we shall see more hereafter in the history of Longinus). 
day received him, and talked with him on many subjects, because he was a wise and intelligent man, and well read in books, and even often asked his advice on business of state, and repeatedly conversed and talked with him confidentially, until John was not a little alarmed, lest the king should deprive him of his office, and substitute Paul in his place. And as John was now in much trouble and solicitude, he began to sound the king, saying, 'If you, my lord, command, we will send father Paul as bishop to Jerusalem or to Thessalonica;' for both these thrones were vacant. But the king easily perceived his cunning, and, to frighten him the more, replied, 'Leave father Paul alone; for we want him here.' And this so alarmed him, that he was now thoroughly taken possession of and troubled by the idea: and therefore he gradually relaxed the vigilance with which Paul had been hitherto guarded, to prevent his escape, and left him without a keeper, and gave his friends full liberty of access to him, that he might have the opportunity of running away: and Paul, nothing loath, fled away, and John once again breathed freely.

II. 8. The manner of his flight is narrated some few chapters further on as follows: As it was now supposed that Paul of Antioch was sufficiently embued in the doctrine of the two natures, and John the patriarch was in great alarm at him, he joyfully took the opportunity of suggesting to him the idea of making his escape. And 
as he was no longer guarded, after having spent so long a time in the bishop's palace, he mixed one evening with the people as they came down, and escaping among them unobserved, went for refuge to a place prepared for him among some ruins. And in time he was sought for, and could not be found: and John now being afraid of the king, went immediately and informed him of Paul's flight. And when he heard of it he was astonished, and filled with anger, and commanded that all the ferries should be occupied, and all ships searched, and all the houses in the outskirts of the whole city, and the suburbs, and monasteries : even the very tombs were opened, and they searched between the rows of corpses there : and, finally, urgent orders were sent to every town and city to the bishops and governors, with a description of his person that he might be recognised and seized: but still he remained undiscovered. Even his brother, who was admiral of the fleet, was arrested, and fell into much trouble. Meanwhile Paul during the whole of this time was hid, as they say, in the city, in a small chamber fixed in the wall, in which he found safety for nine months: and the vigilance of the watch having finally relaxed, he escaped with the privity of the household of Mondir, son of Hareth, into Arabia, where he met with a hospitable refuge until the time when the terrible retribution of Heaven fell upon the patriarch John.

As the patriarch had been thus successful 
separately with two of the four bishops, whose constancy collectively he had been unable to break, namely, Stephan, bishop of Cyprus, and Paul, patriarch of Antioch, he determined next to force John of Ephesus to submission by equally decided measures, the account of which our author gives as follows :

II. 4. When, therefore, Paul had been induced by Stephan to go to the capital, and had been received there, and the synodites now felt quite sure of him, Stephan was next sent to John, surnamed, Superintendant of the heathen and Idol-breaker, as ambassador from the king and patriarch, accompanied by senators and a numerous retinue, to the hospital of Eubulus ${ }^{c}$, in which, after his two former imprisonments in the patriarch's palace, and the separation of the bishops from one another, he had been confined in the house of afflictions, (or penitentiary,) and none of his acquaintance on any pretext permitted to visit him. Hither, then, the embassy came, and addressed the prisoner as follows:'Our lords, the victorious king and patriarch", very lovingly ask thy health, and advise thee to

c The hospital of Eubulus was a late foundation at Constantinople, having been built in the reign of Justin I, and must have been situated near the great church of St. Sophia, as the Alexandrine chronicle mentions that when that edifice perished by fire, the hospitals of Sampson and Eubulus were also destroyed, and the sick in them perished in the flames. Du Fresne Con. Chr. ii. 163 .

"Both these substantives are in the plural, the patriarch as well as the king taking the pluralis majestatis. 
free thyself from this misery, and come and join thy brethren, my lord Paul the patriarch, and my lord Elisha, and rejoice them, as also our merciful king himself, and the holy patriarch; and ye shall again discuss the best means for restoring unity.' But he, on hearing these things, was stirred up with great zeal to answer those who had come to him fiercely and sternly, with anathemas and reproaches and insults too many to record in writing: and so Stephan and his companions retired, embittered and indignant at him. After the lapse of a day they were again sent unto him, beseeching him in the merciful person of the king and patriarch, and saying, 'For the sake of the unity of the church, yield thyself up, and come and let us converse, and do not thus persist in opposition to union.' But they had for answer from him things even sterner than before; for he said : 'Even that former unity I reject before God and man; for it has proved only an overthrowing and an uprooting and a downfall :' and much more too he added of a similar kind. And after they had often visited him, but he would neither submit nor yield to their persuasions, finally they said, 'Inasmuch as we know what you will have to suffer, and have heard the threats of death denounced against you, and that you will not be put to death merely, but in a most painful way, feeling sincere sorrow for you, we wish to say, that we are innocent of the miseries which you will have to bear.' But upon hearing this, he 
burnt with zeal, and expressed his detestation of them, saying, 'Even though you eat me roasted, if I be but quit of the sight of you, I am ready on these terms to be delivered to a painful death.' And so, to be brief, they departed from him. But Stephanus secretly paid him a solitary visit, to tell him of the threats of death determined upon against him, and said, 'See, I have come to thee, that I may not witness the evils that will fall upon thee; look to thyself.' But though much was said, he could not bend his determined spirit, and finally left him, and departed for Cyprus.

II. 5. The first addition, however, to the bitter misery of his imprisonment arose from a painful attack of the gout, which affected both his hands and feet, so that he lay like one dead, unable to stir himself, or move either hand or foot: and in this state he was cut off from all human solicitude, and especially from the care which his relatives would gladly have shown him. But besides this he was tormented night and day with the numerous vermin with which his prison swarmed. For, first of all he was eaten up with innumerable lice, and the cell, moreover, in which he was imprisoned was full of fleas, which day and night tormented him out of his life; nor was this all, for the fetid smell of the hospital attracted infinite numbers of flies and gnats, which settled upon him, and neither could he move a hand to chase them away, nor was there any one to drive them from him. And the fourth and bitterest 
trial of all was occasioned by the bugs at night, which then left their hidingplaces, and covered both him and the mattress on which he lay till his face and eyes were inflamed and swollen, nor could he brush them away. And another, and that his fifth trial, arose from gnats, which, in company with the vermin last mentioned, all night long stung him like fire, especially upon the face, and every part of his body not covered with the bedclothes. And so great was his distress, and the inflammation caused by the five plagues, which encompassed his body within and without, that he wept and lamented, but there was no man to come to his cry, either by night or by day, though he burnt like fire from the stings of all these vermin. And, moreover, Satan brought upon him yet a sixth trial, in some mice which climbed up and made their nest under the pillow which supported his head, and all night long they were scratching and squeaking there. All these distresses were added to the pain of imprisonment and sickness, with no one to help him : and it may be that the record of these things will excite the laughter and ridicule of those who have never been tried, nor fallen into misery, and who, in the words of our Lord, should rather watch and pray that they enter not into trial.

From the exhaustion caused by these tortures, II. 6 . and the inflamed state of his body from the stings of these manifold and bitter vermin, the aforesaid John came almost to his last breath: 
for besides the bitter pains which tormented him, there was the hopelessness of his neglected state, while he looked for some one to pity him, and there was no man, and for a comforter, and one was not found; and that such was his state, from the severity of his trials, he himself afterwards repeatedly declared, both in numerous letters, and in his defence addressed to the synod of the east, and to all classes of the believers, in which he described all these things, and the vision which he saw, protesting before God that he did not exceed the bounds of truth, nor add a single word either to the narrative of his sufferings or to the facts of the vision which appeared unto him openly. And the account which he gave, as in the sight of all men, was as follows:- 'When I was scourged by all these trials, and was sick in spirit, and despaired of my life, there came one day a youth of beautiful aspect, clad in a white tunic with fringes of spotless purity, and as he gently approached me, I imagined that he was one of the attendants upon the sick, who after the midday meal, when all were sleeping, and the doors closed, and silence everywhere prevailed, had visited me because I was inflamed and feverish, both from the annoyance of the vermin and my grievous pains. Approaching me quietly, he said, 'Peace be to thee, father! What is thy cry? How art thou? Fear not.' And I, indeed in the deep affliction of my spirit caused by my great misery, said unto him, "Why askest thou, my son, when thou 
thyself seest me in such great torture?' But the young man said unto me, 'Cheer up, father, and let not thy spirit be sad, but give thanks unto God, who hath not left thee : for thy affliction is not forgotten by Him.' And I replied, 'What cheer or what consolation can there be for me, who die miserably, not merely from the violence of these cruel pains, which, as my sins deserve, are laid upon me, but also from all these vermin which encompass me, and eat me up, and I have none to bear me in their mind, that I might at least be comforted by the sight of them?' And he said, 'We know that thou art afflicted, and that there is no man to take care of thee : and, moreover, that thou art tormented with pain, and with the vermin, and therefore have I come unto thee, to visit and encourage thee. For I know also that thou art thirsty, and that there is no one to give thee water, and therefore have I brought thee a cooling draught : God will help thee; cheer up; and know, that as great as is thy present affliction, so will God multiply thy recompense. Be not sad, nor faint in spirit.' And when he had so spoken, and much to this effect, he went out and returned, bearing a cup, in which were wondrous mixtures which sparkled like fire; and he gave it me, and I drank it with joy and delight, and my spirit was refreshed, and I gave thanks unto God. And to the youth, I told my gratitude, and said, 'God have mercy upon thee, my son, in that thou hast done unto me this kindness, and hast visited and 
comforted and cheered me.' And after he had consoled me with many words, and said, "To-morrow I will visit thee again at this time,' he went away: and I was so cheered by the sight and speech of the young man, that all my pains and miseries grew light. And again on the morrow he came at the same time, and asked me of my state, saying, 'Cheer up, and be not sad; for great shall be thy reward which thou shall receive from God for thy heavy affliction: and thou shalt be delivered from thy distress, and thy people shall assemble themselves to thee: for God is with thee. Let not thy spirit be sad.' And after thus talking with me for some time, he departed. And on the third day, when my eyes were straining in hope of his coming, he came not: and I was greatly distressed, and in deep affliction. But on the fourth day he came again at the same hour, and said, 'I know that thou art distressed, because I came not to thee yesterday: but be not grieved, for I will not forsake thee.' And again he spake much to comfort me, and so departed. And thus for eight days he came to and fro to me, and I was in wonder at his comeliness, and the beauty of his features, and at the speech and knowledge of the young man so lovely of aspect. And after he had come in unto me and gone out eight times, the syncellus of the patriarch visited me to sound me, and after he had used to me many arguments, I finally replied, 'Your treatment of me is on a par with your schismatic faith; for you act to me like 
heathens, and do a heathen deed, in that when you see me in this extreme misery, you fear not God enough to grant me even one of my servants, whom you have shut up in prison, to wait upon me.' And after he had replied, and much had passed between us, and I had sharply handled him, and rebuked him, he went out from me in hot anger, and brought me one of my servants, and said, 'See, here is a servant to wait upon you, and curse us no more :' and so saying, he angrily departed. And from the time I had a servant, the young man came not again, nor did I ever see him more. And when I was astonished and vexed at this, still supposing that he was one of the attendants, I said to the officer who guarded me, 'A young man of your attendants used to come to me, and comfort me, and visit me: but for some days from the time that I have had a servant to wait upon me, he has come to me no more. Tell me, who is he? and is he ill ?' And the guard enquired, "What was the young man like?' And he answered, ' He was of a beautiful aspect, and very handsome in person, and bright and fair in countenance, and clad in a tunic of spotless white, with rows of embroidery above and below.' And the keeper said, 'None of our attendants resembles what you describe.' But he answered, 'I assure you that for eight days he came in unto me and went out, and comforted and cheered me, and talked with me wisely and sensibly :' but the keeper said, 'We have no such person as you describe.' And then he went and 
collected all the servants, and set them before him, and said, 'See, here are all the attendants, nor have we any besides: look if any of them is he.' And when he had attentively considered them all, he acknowledged that it was not any one of them. Upon which the keeper said, 'A vision of God has appeared unto thee, and visited thee, my father: and one of the angels or of the saints has been sent unto thee, to strengthen and encourage thee: for we have no such person as you describe.' And thereupon John was in astonishment, and being full of wonder and amazement, he carefully considered the words and the wisdom and the answers of that youth of wonderful aspect, and said, 'I verily looked upon him as one of the attendants, but God knows who and what he is: but me he hath greatly helped; for he brought me a cup of mixtures, at which I wondered, so bright were they and admirable; and all my pains were lightened. And I myself was astonished at the wise and edifying words which came out of his mouth, and wondered whether one so excellent attended merely upon the sick in your hospital. Henceforward, therefore, in admiration of the goodness of God which has been shown us, we will praise, as in duty bound, the God Who doeth all in His love, and Who alone knoweth the vision of this young man, and who it was that visited us, and alleviated our misery.'

II. 7. In this prison John passed twelve months and nine days, in addition to his two confinements in 
the patriarch's palace: but as even this did not appease the malice of John of Sirmin, orders came for his removal from the hospice, and transportation to an island in the sea, where he was again imprisoned, and treated with great rigour, strict orders being given that none of his friends should on any account be permitted to speak to him. But when he had spent upon the island a period of eighteen months, the chastisement of God overtook the patriarch in so marked a manner as to cause fear and astonishment and terror to both sides alike. And so, finally, upon the command of the Cesar Tiberius, orders were sent to free John from his prison, and bring him to the capital, where he dwelt under the surveillance of keepers rather more than three years, until the death of the persecutor, John of Sirmin.

All these things will be found also in the numerous letters written by him to various persons as soon as he obtained his freedom, together with the vision of the young man who came to him. And let no one who falls in with both the former narrative and also this present account be surprised if he find that they differ from one another in some points being added and others left out: since the utmost he professes is to give a succinct account of what took place for the glory of God. He has omitted, therefore, and passed by much in his former narrative on account of its too great length, while other particulars he has more fully recorded, and especially some of 
the details of the vision, and other points, it may be, as well, though even in them he has used the greatest possible brevity, in order that they might simply be short memorials, and lest, should he relate them too fully, they should be regarded as wearisome by such as afterwards fall in with them.

The determination of the king and patriarch to compel all parties to accept the council of Chalcedon not only brought ecclesiastics into trouble, but also many of the chief laity at court. For as Sophia had originally been brought up in Theodora's tenets, most of the officers of her household belonged to the Monophysite party, and apparently had not hitherto been interfered with. But now determined measures were taken to bring them to obedience, and John details the resistance made by many of them, and even by ladies, in the following succession of narratives.

II. 9. At this time, when every body was possessed by great fear at the stern and terrible threats of the king, many grew alarmed, and submitted themselves to communion. For he even gave orders that no one should attend his levee to salute him on Easterday unless he had previously partaken of the sacrament in his company. As disobedience to this command entailed loss of office as well as the king's displeasure, most of them were terrified, and went over to his communion. A few, however, stayed away, though convinced that by so doing they passed sen- 
tence of death upon themselves, so taken were most of them by abject terror. Among these was Andrew, the queen's chamberlain and pursebearer, a man of active and fervent zeal, and earnest in the ways of virtue from his youth up, and constant in fasting and prayer. At the commencement of the persecution most of the chamberlains, and ladies of the court, and the queen's chief officer of the household, whose name was Stephan, were members of the orthodox community, and had been so from the days of Theodora; but they were prevailed upon by fear, and submitted to take the communion with the king from the hands of the synodites; but Andrew alone was firm, and stood up manfully with mind fully prepared to struggle even unto death. Their majesties therefore, and the chamberlains on both sides, with the view of obtaining favour, attacked him with strife and argument: but he was not in the least frightened at them all, nor ceased from contending with them, nor gave way: and this made the king repeatedly utter the most fearful threats of death itself against him. And as he still would not yield a single point, nor humble himself, nor shew fear of him, the king once grew so angry that he even struck him with his hands in a fury, because he so boldly and firmly resisted him, answering in his turn when he required him to communicate with those who acknowledged the synod, and arguing, and manfully resisting him in words such as the following: ' I confess that you are my lord, and I am 
your slave : and my body is in your hands, to do with it whatsoever you will : but over my soul you have no power, for it is in the hands of God, and my faith is for ever, and neither shall ye nor any other change it, because I believe in God.' And in this way constantly every day they argued one with the other. And as both their majesties loved him for his nobleness and virtue, and valued his good sense and knowledge, they were the more anxious to obtain his submission, that he might still remain in their service: and the king even said in the presence of several of his courtiers, "What shall we do with this audacious fellow who resists and disobeys us? for such a mind and brain as he possesses is not in all our court besides, so that we do not wish to send him away, nor can we possibly let him stay if he refuse us his obedience.' Accordingly they long bore with him in the hope that finally they would convert him, but when he gave no signs of yielding, the king at length briefly said to him, 'Either submit to us, and take the communion with us, or get out of our palace.' Upon which Andrew immediately divested himself of his robe of office ${ }^{e}$, and joyfully laying it at the king's feet, said, ' Never hast thou shown me a greater kindness than this, in separating me from the service of men, and making me give myself to His ministry and service, Who created me and brought me into the world; for henceforth I will serve

e This was the maparavioıs, for which ef. Du Cange Glos. sub Paragauda. 
Him alone.' So saying, he left the king's court, and was confined in a miserable prison in the building called " the palace of Hormisdas ${ }^{f}$ :" and there, after some time, he received a visit from the king's curator, who was sent partly to coax and partly to terrify him, and see whether he would give way, and communicate with them, and not lose his post. The conference lasted for a long time, and at first the curator had recourse only to admonitions and flatteries and persecutions: but when he saw that he would not give way, he began to threaten and terrify him, saying, ' Look to thy life, lest I be compelled to execute upon thee, what I have been commanded.' Upon which Andrew bent down his neck, and stretching out his head before him, said, 'Thou art not a living man, and may God shew thee no mercy if thou dost not bring thy sword and take off my head. But do not mistake, either thou or those that sent thee, and suppose that I ever have on any account held communion with those who divide into two our Lord Jesus Christ, or ever will-the Lord forbid. And may God shew thee no mercy, if thou dost not at once take off my head, and rid me of the burden of this life.'

f The palace of Hormisdas was originally a mere house, the use of which was granted to Hormisdas, when he fled to Constantinople for refuge from the ciuelty of his brother, Sapor, king of Persia : but when subsequently Justinian dwelt there, before he attained to the empire, he conceived so great an attachment for it, that he rebuilt it magnificently, and added it to the palace by a covered way. 
Upon hearing this, the curator departed, and carried his report to the king and queen, who greatly wondered, but also were vexed at his conduct: and in hope still of making him give way, they gave orders for his removal and imprisonment in the monastery of Dalmatus?, which was the highest in rank of all the religious houses both in the capital and its suburbs. They brought him out, therefore, and removed him in the most public manner by day, in the hope of frightening him : but Andrew, as they led him through the city amidst crowds of people, was full of joy and eagerness, and gave praise to God that he was accounted worthy to suffer imprisonment for the true faith, while the mob ran together to see the queen's pursebearer stripped of worldly office, and conducted to prison for the true faith's sake. And all men wondered at him, and many glorified God who had given him the strength thus to despise the world ; and many too were confirmed in the faith when thus they saw him cheerful and joyous, and gave praise to God on his account. But the monks and others who had

g The monastery of Dalmatus (for so we ought to read, the mark of the plural both here and constantly in the case of the monastery of Eubulus being an error of the copyist, who mistook the waw, which represents the genitive case, rov $\Delta a \lambda \mu a$ íov, for a plural termination) was the highest in rank and most ancient and celebrated of all the religious houses at Constantinople. It was founded in the reign of Theodosius the younger, and an account of it will be found in Du Fresne Const. Christ. ii. 154. 
charge of him tried to pull up the hood of his cloak to cover his head: but he uncovered it, saying, "It is a great glory to me to die for Christ's truth : and no man may make my glorying vain.' His imprisonment lasted three years, at the end of which came the chastisement of his persecutors, and he was set free, but not restored to his office at court.

From this history of her pursebearer, our his- II. no. torian proceeds to give a sketch of the empress Sophia, who, he says, during the lifetime of her aunt, the late queen Theodora, from her youth up to within three years before she ascended the throne, used to take the communion with the orthodox, and entirely rejected the communion of the synodites, that is, of those who held that there were two natures in our Lord. And this was a thing known publicly to everybody, and that also a presbyter named Andrew regularly went, and consecrated the communion in her house, and administered it to her, and to all the members of her household: and when he was reserving the consecrated elements, she used to tell him to put by one pearl,-for so they called the pieces of bread,-and place it upon the patten under the cloth; and no one knew who received the pearl so put by except the patrician Sophia, though it was supposed by every one that it was the merciful Justin himself who took it in secret, as he also had an aversion to the communion of those who held the two na- 
tures. Whether or not this was true, we cannot vouch, but have recorded it on hearsay, as being the opinion generally entertained by every body.

The conversion of Sophia to the communion of the two natures was brought about in the following way: His late majesty Justinian had long been solicited by many influential members of his court to appoint Justin, his sister's son, to the office of Cesar; but he kept putting it off, and refusing them. At length a certain Theodore, upon his consecration to the bishopric of Cæsarea, and whose doom God alone knows for his many evil deeds, had an interview with Sophia, and said to her, 'Be well assured, both of you, that the reason why your uncle has listened to no one, nor consented to appoint his sister's son as Cesar, is his indignation at you for opposing him in communicating with those of whom he disapproves, and not communicating with him. For how can he appoint you to share the royal rank with him, if you are manifestly opposed to him? Listen thereïore to me, and go and communicate at Church, and content the king, and then he will content you.' And Sophia being persuaded by his representations gave way, but her union with the synod took place only three years before she became queen.

II. 11. From this account of the empress Sophia, which naturally followed the mention of Andrew, her pursebearer, our historian returns to the fortunes of the other chief members of the 
orthodox party at Constantinople. Among these were three men of consular rank, named John, Peter, and Eudæmon, who counted their lives in the body as nothing compared with the spiritual life by a true faith in Christ; and firmly refused therefore to hold communion with those who divided Him. On this account there was anger against them even unto death, and the turning away of faces; but when every moment they were expecting trial, and the ruin of their estates and families, and of all that they possessed, and everybody felt certain of their utter destruction, God, who saw that they were contending unto death for His name's sake, and for a true faith in Him, saved them. For inasmuch as many members of the senate, and chamberlains, and other nobles, had been prevailed upon by terror to enter into communion with the Chalcedonians, the murmuring occasioned by the violence and compulsion generally used, at length reached the king's ears, and led him to say in the presence of many senators, with the view of making it appear that he prevailed upon no one by violence, as though any one was prevailed upon except by a violence too strong for him to bear: however, be this as it may, God put it into his mind to say words such as these, "We neither have, nor will we force any one of those who have not submitted to us to communicate with us : we leave them to their own will.' And this declaration of the king's determination rescued them, and they were no longer exposed to trials 
on account of their faith: but, on the contrary, they finally reached the highest dignities, and enjoyed the fullest freedom; so that the illustrious Eudæmon, who became Comes Privati ${ }^{\text {h }}$, an office which gave him the charge of the king's privy purse; and the illustrious John, who was descended from king Anastasius, and the son moreover of queen Theodora's daughter ${ }^{i}$; and, lastly, Peter, who was of the family of Peter the Patrician, the queen's curator, were sent to make a treaty of peace with the Persians, in behalf of the whole Roman state. And this great embassy was entrusted to them in spite of their continuing to hold the truth, as they had ever done, in full assurance. The patriarch John, however, erased their names from the diptychk ${ }^{k}-$ an act which caused them great joy: for they said, ' Now we know that God hath pleasure in us, and hath looked upon us, seeing that we are no longer mentioned at the communion of those

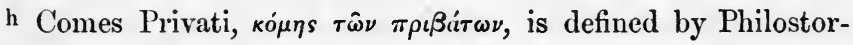

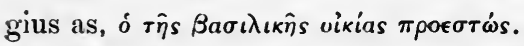

i Theodora bore Justinian an only daughter, of whose son, Anastasius, Procopius gives an account in his Hist. Arc. c. iv.

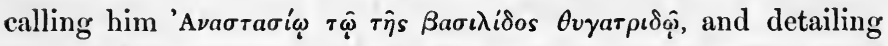
the particulars of the scheme for marrying him to Belisarius' daughter Joannina ; but of another son, John, he knows nothing.

k The diptychs here spoken of were of two kinds-one for the dead, and one for the living; and on them were inscribed the names of those who were to be mentioned at the eucharist. The omission therefore of their names was equivalent to condemning them as hereties; and Evagrius mentions that Anastasius' own name was similarly removed 'because of heresy.' 
who divide Christ into two, after the true indivisible union.'

Less fortunate were two ladies of equally high II. i 2 . birth, who with others of patrician rank were fiercely attacked on all sides, breathing out terrible threats of fire, and menaces of death. And the rest, from the overwhelming misery of the persecution, fainted in the conflict, and for their wealth's sake, and houses and children and substance, submitted to communion, as far as form alone went. But these two boldly resisted unto death, and counted as nothing their possessions, and children and households. Of these the elder, whose name was Antipatra, was the mother-inlaw of the consul John mentioned in the preceding narrative, and her daughter Georgia, who was also of consular rank, and a zealous believer, was John's wife. The other lady, whose name was Juliana, was the daughter of the consul Magnes, who himself was on one occasion banished with all his family, and Juliana among them, though he also was descended from king Anastasius: and subsequently Juliana herself became sister-in-law of king Justin, having married his brother. After much contention, therefore, and a manly contest, they placed both these ladies in nunneries, upon the straits of Chalcedon, and strict injunctions were given, and orders sent to the convents, in which they were severally confined, that unless they would consent to communion, their hair was to be shorn in monastic fashion, and they were to 
wear the black dress used by the nuns, and be further compelled to perform the most menial labours. And these orders were strictly carried out, and they were made to sweep the convent, and carry away the dirt, and scrub and wash out the latrinæ, and serve in the kitchen, and wash the candlesticks and dishes, and perform other similar duties. And as they could not endure and bear with patience such annoyances as these, they also, as far as appearance went, submitted to the Chalcedonian communion, to be set free, and escape from their miserable imprisonment in these convents, if convents they may be called. Upon their submission, they were allowed to return home, and restored to their former rank: but soon the time of chastisement from God came upon both king and patriarch, and they and all men breathed fireely once again after their troubles.

II. I3. There were also two presbyters who underwent a great conflict for the faith's sake, and who both bore the same name of Sergius; of whom one had been the writer's own syncellus', and the other his disciple. While then John was imprisoned in the penitentiary of the hospital of Eubulus, the two Sergiuses were seized,

I Syncellus signifies literally, 'one who shares the same cell,' whence it became the title of a high ecclesiastical dignity, the person invested with it being at once the prime minister and privy councillor of the bishop. Occasionally the syncellus was nominated by the emperor, to watch and control the actions of a dangerous prelate. 
after having long refused to conform, and thrown into prison. Their arrest was effected through the treachery of a relative, who professed to be of their party, but who, after thus playing the part of another Judas, was himself apprehended, and hurried off to the bishop's palace, and imprisoned there. Upon their arrest the two priests resisted those sent to seize them, and argued and disputed sharply with them, until they grew angry, and before a vast crowd they stripped them of their clothing, and tying them up scourged them publicly with the utmost severity, but were not able to break their constancy. And so manfully and with such spirit did they endure and persist in their resistance, that their persecutors wondered at them, and finally imprisoned them in a diaconate ${ }^{m}$. Already they had repeatedly endured the horrors of imprisonment twice both together in the patriarch's palace, and Sergius, the syncellus, once by himself in a monastery called Beth-Rabula ${ }^{\mathrm{n}}$; and their present confinement, which began in February, and lasted forty days, was aggravated by a severe frost. For Sergius the syncellus, the patriarch had a great regard, and sent for him, and advised and coaxed and persuaded him to dwell

m These diaconates were also hospitals; but the sick in them were tended by deacons and laymen.

n Beth-Rabula was built at Constantinople by S. Rabula, bishop of Emesa, in the reign of Anastasius, who provided him with the funds. An account of its erection will be found in the Menologies, under Feb. 19 . 
with him in his palace, and be his cellarius ${ }^{\circ}$; even offering him his solemn promise, that if he would consent, he should not be compelled to take the communion with him: he also added, that ' as I hear of you, that you are a pious man and a monk, abide with us, and be whatever you wish: but if you will consent to take the communion with us, I will immediately make you bishop of whatever city you please.' But Sergius manfully refused, and as he could bow his conviction of the truth neither by promises nor flattering words, and saw his firmness and immoveable constancy, he sent him to the monastery of Beth-Rabula, where however he was treated with considerable kindness, the monks not being ill-inclined to the faith as the rest were, and having no love for the council of Chalcedon, nor even proclaiming it in their worship.

II. 14. There was also a presbyter named Andrew, who had shut himself up in one of the towers of the city wall; whence he was torn at the patriarch's orders by a band of clergy and Romans, who broke open his place of concealment, and pulled him out. But as they dragged and tore him along, they arrived at length in the middle

- The cellarius was the house-steward of a bishop, or monastery, and the immense revenues of the patriarchates rendered the office one of great responsibility. Lanfranc, in the 8th chapter of his Decrees to regulate the monks of the order of S. Benedict, thus describes his duties: 'Ad cellarii ministerium pertinet omnia quæ in pane et potu et diversis ciborum generibus patribus sunt necessaria procurare,' etc. 
of the city; and on seeing a large crowd assembled there, he began to cry out, ' Help! help ! men : I am a Christian, and an orthodox: and if these who drag me along are not heathens, but Christians, as they say, why do they persecute and murder Christians? And why do they drag me through the midst of you, and ye rest quiet, and shew no zeal for Christ's sake?' As he repeated these and similar cries, a large crowd rapidly ran together, and their eyes flashed with wrath against those who had him in charge, as if they would slay them. And when they saw the anger and zeal of all the multitude against them, they ran away, and hid themselves; and so the people delivered the blessed Andrew from their violence. Subsequently, however, he was again arrested, and imprisoned in the monastery of " the sleepless;" whence also, after a protracted imprisonment, and much suffering, he escaped: but having set people to watch for him, they again seized and imprisoned him in the patriarch's palace; but even from thence, after taking part in several disputations, he again managed to make his escape.

Among the various charitable institutions at Constantinople which had sprung from Christianity, no mean place was held by the diaconatesp, which were institutions for the care of the sick and persons in distress. The utility of them was

p For these diaconates, conf. Du Cange, Glos. sub Diaconia. 
the greater, because, while the hospitals were attended only by clergy, monks and nuns, the diaconates gave an opportunity to pious laymen also to devote themselves to works of active benevolence: while in those specially set apart for women, numerous ladies, who might otherwise have found no fitting field for their energies, piously tended the suffering members of Christ's

II. 15. flock. Among those at the capital, two especially were famous for their size and reputation, and both belonged to the orthodox communion. Of these, the first and largest was founded by the divine Paul of Antioch, who, filled with zeal, visited the chief and most famous cities of both East and West, and founded in them diaconates, in which the word of our Lord was visibly fulfilled, that ' this is my rest :' for their object was to give rest to those whom trouble had distressed. On no account, however, would he accept the services of any in the diaconates which he founded who agreed with the synod of Chalcedon.

At the period when the persecution broke out, the head of this diaconate was a great and famous and notable man named Thallus, who had largely increased and multiplied its ministrations by his many spiritual and divine qualities, upon which alone much might be written; and the diaconate continued to flourish under his care, until, by the envy of the devil, an information was laid before the king and bishop, that all the members were opposed to the council of Chalcedon, and had admitted into their fraternity 
many monks and clergymen, and that meetings for worship, and communions and love-feasts were held there. Upon this the blessed Thallus was compelled to send away the clergy and monks, that he might give no occasion to those who were ready to find fault, but he resolutely continued his care of the sick with the aid of laymen only. And when this reached the ears of those in power, because they honoured and admired the man and his ways, they let him alone, and interfered no more all the days of his life. His death took place in the year eight hundred and eightyeight, (A. D. 577,) and a silversmith named Romanus was appointed principal in his stead.

At the head of the other diaconate at this time II. $\mathbf{6} 6$. was a clergyman named Cometes, who also was an active and virtuous man. Originally he had been one of the clergy of the house of my lady Mary of Blachernæ q, but was expelled for the

4 There was a very famous temple of the Virgin at Blachernæ, but she is so universally styled Deipara, both by our author and by all who have described this church, that I feel far from certain of the correctness of the translation.

So beautiful was this edifice, that Nicephorus Callistus describes it as ' the great house of the Mother of God, which vies in beauty with the very heavens:' and its foundation is so illustrative of the times, that I cannot forbear giving it from the Greek Liturgies, where it will be found in the Menologies, or Services for the Saints' days, under July 2. 'Two Patrician youths, we are there told, named Galbius and Candidus, went on a pilgrimage to Jerusalem ; and passing through Galilee, they lodged for the night with a pious woman, who had in her possession a robe which had once belonged to the holy Virgin. This treasure she shewed to 
faith sake.with many others, whom, however, he prevailed upon to keep together, and live with all the strictness of the monastic rule, while he took charge of them in every thing. Soon afterwards some one who admired his virtues bequeathed him a large hall, capable of being turned into a diaconate, to which use he put it, and actively employed himself in ministering in it to all the wants of the poor. At the time, however, of the persecution, an accusation was brought against him of holding assemblies for the administration of the holy communion, and the hall was confiscated, and formally closed by an imperial brief suspended on the door. Cometes was himself banished to an island, and all

the devout travellers, who, eager to gain so precious a relic, offered her large sums of money : but being unable to induce her to part with it, they finally proceeded on their way to Jerusalem. There, while visiting the holy places, the.pious thought suggested itself of engaging the services of a carpenter to make a chest exactly similar to that in which the robe was deposited in the widow's house : and so exact was the counterfeit, that the brothers returned full of holy joly to Galilee; and being again hospitably entertained, they succeeded easily in effecting the substitution, as the true chest miraculously aided in the exchange. On returning to Constantinople, the youths endeavoured to conceal their pious theft, but the miraculous virtues of the robe quickly manifested themselves, and being noised abroad, they were constrained to acknowledge their possession of it to the Emperor, who hastened with all humility to kiss and do homage to the saintly relic, and built a splendid church for its reception, wherein the blessed chest remains even to this day, the palladium of the city against danger, and its best protection against pestilence and war.' 
his fraternity, except a few, dispersed : but his fate did not deter these few from continuing their labours; for retiring to another place, they still devoted themselves, according to their rule, to ministering and tending the poor.

Nor was it merely at the capital that the II. I7. orthodox communities thus suffered, but the persecution carried on there so determinately and despotically, and unremittingly, was the cause of the same violent measures being stirred up against them in every province of the Roman empire, wherever any orthodox communities were to be found. And this persecution was excited by the letters written by John the patriarch, and others: for he was swollen with rage like the waves of the sea, and, like some blazing Babylonian furnace, inflamed not with twigs and brushwood, and other such materials, but with wrath and heat of temper, and eagerness for ruin and slaughter, he burnt and blazed fearfully and terribly, adding to his violence to men's persons those evil deeds which generally go therewith, such as the plundering of their goods and spoiling of their property, on the pretext of their faith; as also painful imprisonments, and heavy chains, and tortures, and the scourge and exile, and the like, in every land and city and village of the realm.

Thus far then we profess that we have written II. 18. that only of which we were eyewitnesses, and 
near spectators of the chicf trials recorded, or actual sufferers ourselves during the whole period to which our narrative extends: but we have thought it right now to chronicle events, which we neither saw, nor learnt of our own knowledge, nor can testify to their truth ourselves, inasnuch as we were far away from the countries in which they occurred; but which nevertheless we had, not from private individuals, or men of inferior rank, but from the chief Catholicus of Dovin, the capital of Persarmenia, and the bishops who accompanied him, and who narrated these events in the presence of multitudes in this the royal city of us Romans ; for having escaped from the dominions of the Persians, they came for refuge to a Christian realm, and were received with great honour by their victorious majesties: and their narrative scrupulously given as upon oath, and in the presence of a numerous auditory, was as follows:

\section{Revolt of Armenia from the Persians.}

When the Magians and princes of the Persians learnt that by the commandment and will of the king of the Romans, all persons, in every land and city of his dominions, were required to conform themselves and come over to his faith; and that such as refused and were disobedient to his will and commandment, were by his orders persecuted and imprisoned, and their goods spoiled, and finally delivered up even to death; lo! said they, in all the dominions of the Romans these 
things are now being done, and it is but just for us also to do the same in all our dominions, and convert to our own religion all other religions within our realm.

They therefore assembled together, and begged 1I. 19. an audience with Khosrun ${ }^{r}$ their king, and said, - $O$ king, live for ever! Behold we have learnt that the Roman Casar requireth, and forceth, and compelleth all persons within his realm to conform themselves to his faith, and obligeth many throughout all his dominions to worship according to his religion. And all those who will not submit, he driveth away, and persecuteth from all his realm. Let thy godship therefore in like manner command, that so it shall also be throughout thy realm: that all religions shall conform to thy religion, and all persons in thy dominions worship according to thy worship; and that such as insolently dare to resist thy commandment shall no longer live.' And when Khosrun the king heard these words of the Magians, he consented thereto, and accepted their counsel: and immediately he began with the Christians first, and sent and seized three bishops and many of the clergy, and commanded them to deny their faith, and worship with him fire and the sun and the other objects of his reverence.

$r$ This Khosrun is the famous Nushirwan, whose eulogy has been written by Gibbon, and to whose many excellent qualities our historian himself bears witness in the sixth book of his history. 
But they argued with him, and manfully resisted, and confessed, saying; "We are of Christian sentiments, and worship and honour the God Who made the heavens and the earth and the seas, and all that therein is: and we cannot leave Him Who is the Creator of all to worship His creatures. Let not the king mistake: for over our bodies thou hast power to do with them whatsoever thou wilt: but our souls are His, and in His hands, and over them thou hast absolutely no power at all.' And when the king heard the bishops testify these things, and much besides of a similar nature, he commanded that they should be that instant flayed, and die. And many evils besides he inflicted upon the Christians, and their monasteries and churches were everywhere levelled to the ground, and multitudes bound and thrown into prison: and the heart of the king was lifted up, and he blasphemed Christ, and said, 'Let us see what Christ the God of the Christians will do unto me: for I do not know who or what He is.' And this then, and much more, was related by these bishops as having been said and done at this time by the king of the Persians previously to the revolt of Armenia to the Romans, and which was occasioned by his command that fire-temples should be erected throughout all that part of Armenia which was sulject to his rule.

II. 20. His next measure, as the Catholicus and his companions proceeded to relate, was to send a 
Marzban $^{s}$ to our territories, attended by an armed force of two thousand cavalry, who came first of all to our city, and commanded us to erect a fire-temple, for the celebration of the rites of the king's religion. But when, said he, he showed it to me and the people of the city, I burnt with zeal, and stood up against him, I and all the people of the city, and we said, 'We are indeed servants of the king of kings, and to him we pay tribute; but we are Christians, and in matters of faith we can yield him no obedience, even though we have to die for our faith's sake. For this same thing was attempted in the days of Sapor, king of kings, who also wanted to build here a temple for his worship, but the people of the land gathered themselves together, and a war ensued, which lasted seven years, and at the end he made terms, and published an edict, commanding that no one should meddle or interfere with us as regards our being Christians for ever.'

s The title of Marzban is exactly equivalent to the German Markgraf, and English Marquis, and signifies Lord or Warden of the Marches, or border lands. Adelung, in his Krit. Wörterbuch, enumerates an endless number of dialects in which Marz or Mark has this meaning, and we retain it exactly in landmark, which signifies the edge, border, limit of the land, not a sign to mark the boundary. Ban the Germans retain as the title of the Warden of Croatia ; and Adelung says, Ban, Pen, in Goth. Fan, signities high, the summit, the chief lord. As regards the title King of kings, which occurs a few lines below, it is perhaps hardly necessary to say that Khosrun is meant by it, as it was the regular title of the Persian monarchs. 
And we further shewed him the original copy of king Sapor's edict: but he refused to obey it, and in obedience to Khosrun's commands, began by main force to mark out a site, and to dig and lay the foundations, and to build the walls; while at the same time he made determined preparations for battle. And I besought him again and again, but availed nothing, nor would he attend to me, or even deign me a single look; and finally I sent everywhere to all the people of the land, and when they heard the news, they burnt with zeal for the faith's sake in Christ, and assembled all as one man, to the number of ten thousand, armed for battle either to live or die for Christ, and firmly determined not to permit a Magian and heathen temple to be built in their land. And when there were assembled all the princes and chieftains of the land, we went to the Marzban, to the place where he was building the fire-temple, and had a long conference with him, and boldly resisted him, saying, 'We are Christians, and subjects of the king of kings : but in matters of faith we neither can nor will yield submission to any one, and even though the king come in person, yet as long as any one of us lives to resist it, there shall no heathen temple be built to all eternity in our land. Depart therefore without war or devastation from our country, and tell the king of the firm determination of our minds to defend our faith; and let him take such steps as he thinks right; for though it cost us all our lives, we will never permit a temple for the 
Magian worship to be erected in our land?' A long conference followed, in which the Marzban protested to the people assembled that he must build the temple according to his orders, and argued with them, and testified against them, saying, 'You are resisting the commandment of the king of kings, and setting him at nought, though it is in his power to command you to be put to an evil death: beware therefore what you do.'

But when he saw their readiness and their preparations to resist him, and perceived moreover that they were stronger than himself, he retired, with threats nevertheless and protests against their conduct: and returning in great anger to the king, informed him of all that had taken place. And he, on learning it, was roused to anger, and burnt with indignation; and vowing death against all the people of the land, he sent against them the Marzban with a body of fifteen thousand men ready for war, with instructions to exterminate any who ventured to resist his commandment, and erect there a shrine for a temple of fire. But the people of the land, when they heard thereof, assembled together to the number of twenty thousand men, and made ready for battle, prepared to struggle even unto death in defence of their Christianity. And on the arrival of the Persians, they drew themselves up in order of battle against them; and shouting, 'In the name of the Lord Jesus Christ,' they moved onward to the attack. And Christ broke the foe before the children of the land, and they utterly 
destroyed them as one man, and slew the Marzban, and took off his head, and sent it to the patrician Justinian, who was encamped at that time at 'Theodosiopolis' in the marches. Such then were these events, and they were followed by others, the full recital of which would occupy greater space than we can spare.

II. 2 I. And when these things had taken place, and the whole people of the Greater Armenia saw that a fierce war was stirred up against them firom the wicked kingdom of the Persians, they all gathered themselves together from one end of it to the other, and ran for refuge to the kingdom of the Christians, saying, 'Henceforward we are the servants of the kingdom of the Christians, and have run to take refuge in the Roman realm, that it may deliver us from the savage violence of the Magians.' And all this, and much more, the Catholicus of Dovin, and the other bishops who were with him, related in the presence of our merciful king and queen, and of the whole senate: but we have admitted only a small portion of it into our history; for they recounted also the details of the repeated con-

t Theorlosiopolis is better known by its other name of Resaina, by which it is frequently spoken of afterwards, and was situated in Mesopotania. The patrician Justinian was the grand nepliew of the Empresor of that name, and in the latter part of Justin's reign conducted the war against Khosrun with considerable ability. Evarrius (Eceles. Hist. V. 7-I.5.) gives a brief account of these transactions confirmatory of the more stirring narative of .John. 
flicts and devastations which followed, and in which the Persian hosts had more than once been vanquished, and their elephants captured; but which we at present must omit for want of space.

Such then is a short abstract of the account II. 2 . of the Catholicus of Dovin, the capital of Persarmenia, related in the royal city of us Romans, by him, and the other bishops and the numerous noblemen who accompanied him, in the presence of many witnesses : and all on their arrival were received with distinguished respect, and large presents and regal honours paid them, and high dignities granted them, and some of the royal residences and chief monasteries were set apart for their abode, and an income assigned sufficient for their proper maintenance; and titles of high rank were also sent to the leading men in the land, as also a large subsidy of gold, and orders that no tax should be levied for three years for the king of the Romans, but that they should do their best to assist those who, having accepted the sovereignty of the land, were warring in their defence, and that of the whole of Armenia against the Persians. And this they did for a long time, and the Magian people fell before the Christians on numerous occasions in the first six years of the time during which the war lasted. Of these events we will subsequently give some brief particulars in their proper place. As for the Catholicus, at the end of two years he died 
at Constantinople, and never returned to his own land.

1I. 23. Upon the first arrival at the capital of the Catholicus of Armenia, and the bishops and nobles in his suite, as men who had fled from the wicked and heathenish kingdom of the Magians, and had come for refuge to the kingdom of the Christians, meeting immediately upon their arrival witl so honourable a reception, they went, without making inquiries, and through inattention communicated in full confidence with the patriarch of the city, as not being aware of the schism and quarrel which had arisen in all the churches of the Roman dominions, from the corruption of the faith by the council of Chalcedon. But when intelligence of this reached the bishops and leading men of Armenia, they were angry with them, and wrote sharply to them such things as may now be well passed over in silence; and therefore they withdrew, and separated themselves, and having fitted up a large hall, in a building granted to one of their nobles for a residence, into a church, they there formed a distinct congregation, and celebrated the communion after their own manner; and continued so to do even after the death of the Catholicus.

II. 24. We are well aware that the events which happened in our time are numerous, especially now at last, and that they exceed the limits of history: and more particularly after the defection of Armenia to the Romans, which took place in 
the year eight hundred and eighty ", of the era of Alexander, (A. D. 569.) For this act was the cause of constant and numerous battles on all sides, and of dreadful devastations, and the shedding of much blood. For the Magian, after his defeats, was again lifted up in his wickedness, and fell upon the Roman armies in Armenia, expecting to route and annihilate them utterly. But when he found himself unequal to this, he turned aside and entered the Lesser or Roman Armenia, in the hope of being able to capture and pillage the city of Casarea, in Cappadocia: but the Roman armies hemmed him in, and drove him back from thence, and gave him battle, and deprived him utterly of his baggage, and made him return ashamed; and had it not been for a disagreement between the Roman commanders, he would scarcely have escaped with his life. And again the Roman king sent presents and subsidies, and despatched fresh troops to Armenia to ensure his victories; but nevertheless, after it had been completely taken possession of and occupied by the Romans, and they had gained numerous victories, and had reduced several powerful tribes to obedience, finally, either by the unskilful measures of their generals, or because in many things they had brought upon them the anger of God, when they were not fewer in number than a hundred thou-

u The real date was A. D. $57 \mathrm{I}$, consequently $\infty ; \angle 0$ has probably been omitted from the text. 
sand men, they were stricken with a panic at the presence of a single paltry Marzban, with but thirty thousand troops, and all the Roman hosts fled, with the loss of their arms and horses, and were put to shame. And the Persian was lifted up, and increased in strength, and overran and conquered the whole of Armenia, and all the land asked for terms of peace from him, and he granted them; whereupon it returned to its allegiance, excepting those only who had betaken themselves to Constantinople, when seven years before they rebelled against him, and the struggle began $x$.

After this, men of high rank in both kingdoms were sent as ambassadors to examine the matters in dispute between the two realms, and to confer about peace; and for more than a year they were occupied at the borders talking and discussing, and disputing with one another, but without effecting any thing. And at first the Persian required a sum of money, before he would make peace; but at this the king of the Romans was stirred up manfully, and said, 'This man demands of us gold, as if we were afraid of him, or subject to him; but let him know that as he never yet has received of us a single mina, so neither shall he as long as we live. And if he treats not with us on equal terms, kingdom with kingdom, we will not make

x A more full, but still piecemeal, account of these events will be found in the sixth book. 
peace with him.' And so, finally, the Persian gave way on this point; but nothing came of it. But of all this, it is not possible for us to give the particulars: many books would scarce hold a full account of it, and of the other contests in the church and the world, which happened in our days, and which therefore, from their too great length, we must omity.

y Before completely dismissing the subject, it may he interesting to add a translation of Saint Martin's account of this seven years' war, in his Mémoires sur l'Arménie, vol. i. p. $33^{\circ}$, and which is as follows:-' In spite of the treaty made between Vahan Mamigonean and king Balasch, the Persian sovereigns frequently persecuted the Christians in Armenia, in the hope of making then abjure their faith. Nevertheless during most of the reign of king Khosrou, Armenia was tranquil, and enjoyed as much prosperity as was possible for a land which was necessarily the battle field for the incessant struggle waged between the Greek and the Persian empires. Towards the end however of his reign a war broke out, which for many years spread devastation and slaughter through every part of the land. For Vartan Mamigonean, irritated by the persecutions which his Clrristian countrymen had to endure, raised in A. D. 57 r the standard of revolt, marched upon Tovin, the capital, of which he made himself master, defeated and slew beneath its walls the Narzban Souren Jihrveschnasbean, and with the support of the emperor of Constantinople, assumed the reins of government as an independent prince. And at first success seemed likely to crown his enterprise : for the army which Khosrou sent to suppress the rebellion was defeated by Vartan in the plains of Khaghamakha; on the shores of the Ourmiah lake. But this reverse served only to rouse the aged king to greater efforts, and upon the approach of his most famous general Bahram Tchoubin, with a numerous army, the insurgents, weakened by intestine discords, did not dare to meet him in the field, and some even fled to 
11. 25. Contemporaneously with the disgrace which befell the Roman arms in Armenia, there was seen in very deed the meaning and accomplishRom. i. ment of the apostolic lesson, 'that the wrath of 18. God is revealed from heaven upon all iniquity and wickeduess of men, who hold the truth in unrighteousness.' For because Christians, on slight and insufficient reasons, had risen up as stern and violent persecutors of Christians, mercilessly and without fear of God, yea, savagely, barbarously, and unchristianly, 'like unto a lion roaring that he may break in pieces, and as a lion's whelp that sitteth in secret,' therefore did the Lord arise before their faces, and lay them low,

Constantinople. The Greek emperors in vain endeavoured to prop up Vartan's tottering rule, and after a seven years' struggle, the Armenians, in A. D. 578 , wearied with the ravages of war, made voluntary offers of submission, which were accepted by the Persian king, and Mihram Jihrvegon appointed to be their Marzban.'

This summary of the seven years' war is gathered by Saint Martin from the writings of the Armenians themselves; and should it interest any one in the brave endeavours of this people to maintain their faith in spite of the incessant persecutions of the Zoroastrian priests, he will find a stirring recital of a more successful struggle waged a hundred years before, in the translation (into French) of the history, which Elisée Vartabed wrote at the request of the hero of the war, Vahan Mamigonean, the ancestor of the Vartan mentioned above, by the abbe Gregory Karabagy Garabed : other available sources of information are, the translation of Moses Chorenus, an Armenian bishop of the fifth century, by Le Vaillant de Florival ; Avdall's translation of Michael Chamich's History of Armenia, Calcutta, 1827; and the recent translations of Dulaurier. 
so manifestly that it was known and observed of all men. For they had intemperately practised every cruelty against the members of their own body, even against the whole people of the orthodox, in vehement wrath, not treating then in that orderly and gentle manner which becomes just and Christian men, but stirring themselves up to be violent and merciless persecutors. For they sentenced the servants of God to cruel imprisonments in dark and narrow dungeons, though they were aged men, infirm and firail in body, and venerable for their years; yea, they condemned them to merciless banishment, without fear of God; ordering them in bonds and strict confinement, to be left exposed to hunger and thirst, and no friend permitted to visit them: and when they banished them, they gave directions that the exiles should have no mercy shown them, but be ill treated in every possible way, in the expectation that the greatness of their sufferings and trials would compel them to submit themselves to the will of their tormentors. And when, by force and compulsion, they had made any submit, they then, in violation of all law and canonical order, pronounced the ordination invalid, which they had received long before at the hands of orthodox bishops, and ordained them afresh, both priests and bishops. And so many were their deeds of this kind, that the time is too short to relate them, nor, as the event plainly proved, could the justice of God either tolerate or endure them. For quick and speedy 
was the wrathful sentence sent down fiom heaven upon this cruelty and savageness, or rather upon those who, unrestrained by the fear of God, had practised it, even upon John the patriarch, and upon the king, who was led by him astray, and who did these things under his influence. For both were scourged by the same angry rod, and received the same sentence, that they should be given over to evil spirits. And they had much meanwhile to suffer, which was terrible and alarming, but which shall now be veiled by us in silence, because of the honour due to the priesthood and the royal dignity; but which being wrought in them during a lengthened period of time by the devils, to whom they were severally given up, became matters of common report and conversation, and to the truth of which, and their terrible and fearful reality, we have the testimony of all the people of those times.

II. 26. Upon this alarming chastisement falling upon the king and patriarch, the bishop John was at first rather stimulated to increased persecution of the believers, by the operation and incitement of the evil spirit which wrought within him, so that every day, without knowing what he was doing, or settled purpose, he gave utterance to savage and cruel threats, unwarned by the chastisement which, from time to time, he received from the evil spirit; and thus he still more irritated the righteous Judge, Who sent yet again upon him a disease of the bowels, and internal 
pains, and the bitter agonies of gout: so that, being now tormented beyond hope of cure, and pain following upon pain, and blow upon blow more intensely every day; and all the care of his many physicians being in vain, and no respite or aid appearing, at length, as the magicians confessed before Pharaoh, saying, 'This is the finger of God,' so also was he now forced to understand that his chastisement came from Heaven; and he began with sighs and tears to say to his physicians, - Why weary ye yourselves, my children, about me, a miserable wretch? for my maladies are past the power of healing. For all these tortures have been inflicted upon me by the just sentence of Heaven because of my cruelty, and men cannot heal them. For now I know and understand that as I, without mercy, smote many, so am I now singly scourged without mercy by the One.' And in process of time the physicians ceased to attend him, for he himself refused their services; and he became unable to take food, and even when he swallowed any thing liquid, he quickly threw it off his stomach, and finally his bowels came away piecemeal. And his torment was not only thus bitter and severe, but also protracted, so that he often said with tears before many people, 'I know, O Lord, that I have done evil in Thy sight, and that the curses of Thy aged and honoured servants have overtaken me, and stirred up Thy wrath against me, because I treated them without mercy.' His punishment began about a year 
after he commenced the persecution, and never abated: and as he did not even then desist from the cruelty of his measures, there finally fell upon him this severe and most painful torment, under which he lingered two years, and at length departed from this present life in the thirteenth year of the reign of king Justin. The latter still lingered under his maladies, finding occasional relief, but never being entirely delivered from his sufferings until the day of his decease.

II. 27. His death was followed by the immediate recall of Eutychius ${ }^{z}$ to the patriarchal throne: and as we have mentioned briefly before the purport of this chapter, so now we will shew at length the just judgment of God, which not only at the day of future trial, but also here, visits men with retribution according to their deeds. For John the bishop of the capital, of whom we are now speak-

z The deposition of this prelate had been one of the last acts of Justinian's reign, who, in his eagerness to unite all parties within the church, had adopted as his standard the tenets of a subdivision of the Monoplysite party, who held that the body of Christ was not subject to corruption. The head of this party was Julianus, and a Syriac translation of the great work of Severus of Antioch in opposition to his views is extant among the manuscripts of the British Museum. Eutychius, to his honour, opposed the Emperor's scheme of elevating this doctrine to the rank of orthodoxy : and by a stretch of the imperial prerogative, by no means uncommon in those days, was at once deposed, and went into retirement. It follows therefore that John's elevation was entirely uncanonical, and hence the treatment of his pictures, \&c. regarded by our historian as part of his retribution. 
ing, being urged onwards by savage violence, and hurried along by pride and arrogance like a boy, and intoxicated and drunken with power, took down and erased all the pictures of the orthodox fathers, and fixed up his own everywhere in their place. And while he thought not that he should die, suddenly the time of his departure overtook him, and Eutychius his predecessor, who had been deposed, was summoned to fill his place. And though by the persuasion of their majesties he consented upon his return to let all that had previously passed between him and John rest in silence, yet his pictures he everywhere obliterated, and expelled them, not merely from the episcopal palace and the churches, but even had a search made for them, lest any one should here and there escape notice. And the inhabitants of both towns and villages, when they learnt his will, that they might not be informed against, obliterated all John's pictures, whether painted on the walls or on tablets, and took them down, and fixed up those of Eutychius in their place, so that at most only one or two remained here and there: 'and God requited the wickedness of Jud.ix.56. Abimelech, which he had done, in slaying his brethren, fifty men, upon one stone.' And this became a wonder and an astonishment to all men, that God so quickly had recompensed John even here, and that as he had done, so it was done unto him, 'and the Lord returned the re- I Sam. quital of Nabal upon his own head.' And thus ${ }^{\text {xxr. } 39 .}$ the pictures of John were obliterated as soon as 
he was dead, just as he had boldly taken down the pictures of the saints and set up his own.

The time during which John a occupied the patriarchal throne was thirteen years, more or less.

II. 28. Among the satellites of the patriarch was a certain deacon, named Theodulus, who distinguished himself by the activity he displayed in the persecution, and who also was overtaken by the Divine vengeance. From his youth this man had been remarkable for his demureness, and humility, and quietness, and had thereby earned with many the reputation of extraordinary virtue. These qualities had moreover gained him an introduction to the king Justinian, who, on seeing his humility and sedateness, employed him as his almoner, and intrusted him with large sums of money to distribute to the poor, and prisoners, and to the monasteries in the suburbs and outskirts of the city. The money thus given him amounted to many talents; and his services were not confined to the capital, but he was often sent on similar errands even to distant countries:

a 'The opinion of Baronius cencerning John is by no means a favourable one : for speaking of Eutychius's deposition, he says, 'his successor was John Scholasticus, apocrisiarius of the church of Antioch, a man plainly the slave of glory, and a trafficker in holy things, and who purchased his high rank by fiattery.' (Eecles. Hist. sub A. 1). 564.) liarlerus is even less complimentary : for referring to the fact that the Greek church celebrates him as a saint, he says, "I find no traces of sanctity in him: away with lim therefore from the sacred Fasti.' (Conf. Moreellus in Kal. Eicel. (onst. ii. 229.) 
and finally, by little and little, he amassed for himself out of the sums given him to distribute great riches. After Justinian's death, he was employed by Justin in the same confidential post; and when the persecution broke out, being anxious to obtain the favour of men, he was the means, as one who held a confidential position, of bringing, in company with John and the rest, many evils upon the whole body of the believers. His business was to go in advance to the monasteries, and there, by his false oaths, he deceived many: but finally, he was detected in his wickedness.

His zeal and vehemence in defence of the synod, and the whole heresy of the two natures, was even greater than that of John himself; and as he was perpetually slandering the believers both to the king and patriarch, and exciting cruel anger against them, he was himself invested with power to seize and imprison and torture whom he would, besides being often intrusted with special commands, in the execution of which he treated the believers in the most wilful manner. Even the patriarch himself was in no little alarm and fright at his rising power, and the more so when the Arians everywhere were put under his authority. But when he was thus lifted up, and still busied with persecution, God severely scourged him, so that he could no longer walk erect. For while he was still in his strength, and angrily urging on the persecution, it so happened that his own and his wife's cousins and his 
secretary embarked in a carvin ${ }^{\text {h }}$, or small vessel, to cross the sea: but it foundered, and all on board, two or three only excepted, were drowned. Nor was this the only calamity which befell him: for, soon after, his wife died, and a severe illness stretched him also upon his bed, where he lay in much pain for three years. And now, in the misery brought upon him by these severe chastisements, he confessed with bitter tears, saying, -Woe is me! for the curses of those whom I persecuted have overtaken me, and the cry of those whom I oppressed has gone up before God, and therefore is this my humiliation sent upon me from Heaven.' For it had so happened, a little time before, that somehow or other he offended his vestryman, who had the charge of all which he possessed; and for revenge he went in secret and informed the king of the talents which his master Theodulus had secreted, and which it is said-for we have no means of knowing exactly -were from twenty-four to thirty. These the king had secretly removed, and then sending for Theodulus, he said; 'We are in great need, 0 deacon, of money for the wars; and if thou wilt lend us two or three talents, we will requite thee.' And he replied, 'Me, my lord, whence could I have talents?' ' By my life and my salvation,' exclaimed the king, 'say you that you have none?'

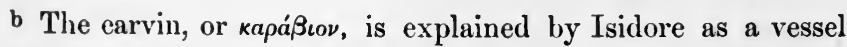
made of osiers and hides: its Ar. equivalent قارب is the small vessel used in disembarking from a larger one. In modern languages it still exists in the Portuguese, Caravela ; Italian, Caravella, \&c. 
'None, certainly,' was the answer; and he took his oath that he was not worth a talent. Upon this, the king ordered the talents to be produced, and with them the vestryman, and sternly said, ' Knowest thou these? and how didst thou swear, and perjure thyself unto us and unto God? Thy shame suffice thee: depart hence.' And so he departed, ashamed like the shame of a thief when he is caught, and hid himself for shame; and became the scorn and ridicule of all men.

Thus then disgrace was added to his other afflictions, and he was further dismissed from his office, and continues so to the present day.

Another of the chief persecutors was the king's II. 29. quæstor, Anastasius, who by birth was a Samaritan; and when his countrymen in Palestine were being brought to judgment by Photius, they accused him also of practising their idolatrous customs, and an indictment against him was drawn up, and laid before the king. And upon this the alarm of Anastasius was extreme, and he ran hither and thither, and gave bribes on all sides, and so the indictment disappeared, and no inquiry was made into his conduct. This man was the foe and stern enemy of the believers, and used to threaten them severely; and whenever in the patriarch's absence he acted as his commissary, he used the opportunity for stirring up the king against them by his calumnies : and on John's return, the two persisted, whenever they had an audience, in these representations, and so abused the king's confidence, that, 
being roused to anger, he published decrees of alarming severity against the whole body of the believers. And, as was known to every one, Anastasius was constantly in the habit of receiving sums of money from John, and was his adviser and inciter to every thing that was abominable, like his accursed teacher Etherius c, who prided himself upon Anastasius having been from the first a labourer in the same cause as himself, and eager to walk in all his footsteps.

But justice could no longer endure this man's cruelty, who, while professing himself a Christian, used the opportunity of his office secretly in every way, and on every pretext, to smite the Christians, as only a heathen and a Samaritan would do, and conspired with the other secret heathens to prevent the unity of the church. But God saw his crafty purposes, and while he supposed that he was deceiving both God and men, He brought his falsehood to light before the whole church, when it was crowded with people, on the day of the adoration of the holy cross of our Saviour. On this festival the cross is brought out, and set up in the great church, and the whole senate and all the people of the city assemble to adore it: and with the senate came also the quastor, to show forsooth in pre-

c Evagrius, Eecles. Hist. v. 3, applies the same epithet of exse-

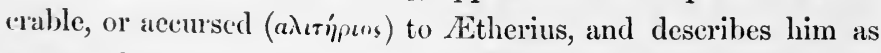
a man whose sole delight was in calumniating and bringing evil upon others. He was put to death by Justin, on a charge of conspiracy against his life. 
tence that he also was an adorer. And as they formed themselves in rows, and drew near in order, he too approached the holy cross; but before he could adore it, a demon entered into him, and lifted him up, and threw him on the ground before the holy cross,-yes, this man, I say, who falsely and deceitfully, in mockery of the Christian religion, had drawn near to worship -and he began to foam, and was torn by the devil, and deprived of his senses, and screamed so long, that at length the patriarch gave orders for them to lift him up, and carry him through the throng, and place him in an inner apartment of the church: while the whole multitude who filled the church long continued crying Kyrie eleison, being in wonder at the revelation of his fraud, and at the chastisement which the Lord of the cross had inflicted upon him, before the eyes of so many people. And terror fell on many deceivers and hypocrites.

As for Anastasius, he never again raised his head, but being thus tormented by the devil, he lived about a year and a half, more or less, and so departed from this life.

Nor did vengeance fall only upon individuals, II. 3 o. but as the synodites had rooted up the churches of the orthodox during the persecution, so after a short time, by a righteous sentence, the altars of their churches throughout Thrace, and up to the very walls of the city, were rased to the ground by the barbarians. For it seemed good to the rulers in church and state, to over- 
throw the meeting-houses of the believers, and level their altars with the ground: but when a short time only had elapsed, a barbarous people, who from their unshorn hair are called Avars, invaded the country and marched up to the outer walls of Constantinople: and all the churches in Thrace were plundered by them and desolated with the whole land, and the altars were stripped and overthrown, and the ciboria destroyed and plucked down, even to the very walls of the city. And many of them understood this just judgment, and said, 'Lo, that which was unjustly done by men of our own party unto those who do not agree with us, in uprooting their churches, this has God done unto us in anger, and our churches also are rooted up and ruined.' - And all men wondered thereat and praised God, Who requiteth every man according to his works.

II. 31. Upon the death of the patriarch John, Eutychius was once again summoned to fill the archiepiscopal throne, from a monastery at Amasea e, in the north. And on his arrival at

d The ciborium was properly a covering built over the altar, and supported by four pillars at the corners; and in this sense S. Chrysostom uses it to explain the 'silver shrines of Diana,' in the Acts. Subsequently the name was also given to the pyx erected under it for the reservation of the host.

e Amasea is in Pontus, and Eutychius had been apocrisiarius there before his elevation to the see, and had retired to his old monastery upon his deposition. 
the capital, he was received by their majesties and the whole city with the utmost pomp: for wonderful rumours were spread abroad concerning him, to the effect that he wrought miracles and did mighty works. The whole city therefore rejoiced at his arrival, and congratulated themselves upon their deliverance from the perfidy and falseness and usurpation ${ }^{\mathrm{f}}$ of John, who had been appointed in violation of canonical order ; and moreover originally he held a menial position, and subsequently was a jurist; nor was it until a very short time before that he received the tonsure and became a clergyman, and then unexpectedly bishop of the royal city; but this in no way broke him of his habits as a layman and jurist. Eutychius, on the contrary, was a sober monk: and already at his deposition he had occupied the throne of the capital for twelve years; and on his expulsion John had held the episcopate also for twelve years, and just entered upon the thirteenth: and so Eutychius returned, feeling as though he could not sit upon his throne until he had excommunicated John, and cast his memory out of the church of God.

His return brought with it a practical diffi- II. $3^{2}$. culty as to who had been the real bishop of Constantinople during the twelve years of John's

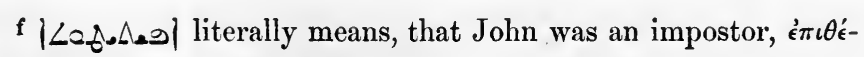
$\tau \eta s$, his appointment being uncanonical, and therefore invalid. 
occupancy: and therefore the archdeacon of Rome, after the death of John of Sirmin and the restoration of Eutychius, spake with much freedom before the king, as follows: 'Be it known unto your clemency, that according to the canons and rules of the church, if John was patriarch,-and he certainly acted in that capacity all the days of his life,- - then Eutychius was not patriarch, and it is utterly impossible for him to be admitted into the church, and occupy the throne. If however Eutychius is received, and admitted as patriarch, and occupies the throne, then John and all that he did cannot be acknowledged by the church, but must be rejected, whether it be the consecration of bishops, or ordinations, or any baptism which he performed, or the consecration of a church, or an altar, it is all null and void, and his name must be erased, and proclamation made of his expulsion from the church of God, and the order of the priesthood. And this is the more necessary, because the two have mutually deposed and excommunicated each other, and all who severally communicate with them : so that it plainly follows from the canons, that one or other is deposed and ejected from the church.' And when the archdeacon had said these things in the presence of the king, and declared that the pope of Rome held the same view, he was sharply rebuked, and told to hold his peace, and not trouble himself about the exact letter of the canons. And so he held 
his peace, and passed the matter by; and the rule of the canons was trampled under foot and broken.

The archdeacon of Rome had however only II. 33. expressed the general opinion: for all men had expected that Eutychius, upon his recall, would refuse to occupy the patriarchal throne, until a synod had been assembled, and full enquiry made. But on arriving at the city, he mounted and sat upon his throne without opposition : and both parties drank and swallowed down the turbid dregs of the mutual excommunications, which John and Eutychius had pronounced against each other and their respective adherents; so that astonishment took possession of all men.

But though Eutychius abstained from a ca- II. 34 . nonical enquiry into the validity of John's patriarchate, fearing lest he should stir up some opponent against himself, and lose his manger, he showed his hatred and fierceness against him by giving orders that all his pictures should immediately be extirpated and removed from the palace; which John had himself rebuilt in a magnificent manner, after it had been destroyed by fire. His pictures also elsewhere were obliterated, and his name no longer heard at the recitation from the diptychs of the former patriarchs of Constantinople, until the king expressed his displeasure at the omission. He moreover drove away and deprived all his relatives of their offices, and heaped upon his pre- 
decessor's memory every possible contumely. And every one who wished to please him, when they saw his infatuation, spoke ill of John, and he listened to it with pleasure: and finally, his folly reached such a height, that he used openly to say, 'John never was bishop of Constantinople, but was simply keeping my place, having himself nothing to do with it.' But these absurdities deceived no one but himself: for all knew that he had been deposed, and that John was appointed in his stead, and had occupied the see, and formally pronounced his deprivation.

II. 35. The restoration of Eutychius did not promise much peace to the orthodox party: for in his exile he had occupied himself in his monastery in tearing up and arranging books of lacerations, as a proof from the fathers of the doctrine of a quaternity instead of the Holy Trinity, as it had been set forth at the synod of Chalcedon in the wicked tome of Leo. For he in like manner taught that there are two natures in Christ even after the union, and said that all the fathers also acknowledged this. Immediately then that he had been reinstated in his see, he busied himself in eagerly sending copies of these books to the leading men, and ladies of note, requesting them to read and understand, and so be led themselves to acknowledge the two natures: and especially he sent them to such persons as were

g This simply means that he drew up a Catena, or string of passages from the fathers in support of his views. 
offended at the doctrine of the two natures, and held, in accordance with all the fathers, that there was but one nature in Christ as He existed corporeally. But the contrary effect to what he had expected followed upon the perusal of his books: for even his own suffragans and people generally ridiculed his absurdity, and the whole city began to be excited, and those especially, who had not drunk of the turbid dregs of Nestorius' gall, expressed freely and in severe terms their indignation, including some of his own bishops. And at length so much excitement and debate was stirred up against him, that they assembled at the palace, and frankly said, 'Know that if thou dost not gather in thy books, and say nothing more upon this matter, thou wilt cause a schism in the church of God, even among our own party.' And so he gathered in his books, upon which the excitement died away, though he continued to hold the same views as before.

After these things, the haughty Eutychius, who II. $3^{6}$. belonged originally in the main to the heresy of Paul of Samosata, was not long in precipitating himself into a fresh snare, by adopting the views of those who denied the resurrection of the body: nor did he merely assent to their opinions, but set himself industriously and zealously to confess and publicly teach their doctrine, saying, ' These bodies of men do not attain to the resurrection, but others are created anew, which arise in their stead.' And this view he not merely taught by word of mouth, but even drew up 
written treatises in its defence, and distributed them publicly, and constantly spoke of nothing else. And again, on this account the whole city was excited against him, and murmurs were every where heard, and expressions of scorn and ridicule. And those especially were scandalized who were of his party, and finally they said to him, 'If thou dost not hold thy tongue about this doctrine, we will in a body excommunicate thee.' And even this threat did not divert him from his opinion, but he attempted no longer to teach it, especially as all men had come to regard him as a heretic and a simpleton.

A few chapters further on, John repeats this narrative as follows:

II. 42. The vanity of his heart often led the patriarch Eutychius astray; and whereas originally he belonged to the heresy of the Samosatenians, on being made bishop, he sought to conceal this fact; and to please those who had appointed him, and who held the Chalcedonian tenets, he stood up and played the man in the heresy of the two natures, and began to persecute severely. And when he was driven from his throne into exile, he composed a large work of instruction, divided into heads, concerning the two natures, which upon his restoration after John's death, as we have previously narrated, he began to distribute among the houses of the leading senators, both to men and women, especially to such as held back from the confession of the two natures. And with his book he sent this message, 'Read 
and learn that the church confesses two natures in Christ after the union.' And laughing at his absurdity, they sent him his books back again. Next, after a short interval, he heard of the heresy of Athanasius, who after having been head and founder of the heresy of those who number the substances, that is, the essences and natures in the Holy Trinity, having been led astray by the error of John Grammaticus, of Alexandria, he further said that these bodies of ours do not rise again at the resurrection of the dead, but that others are made ${ }^{h}$, which come to the resurrection in their stead. And from this madness, worthy of heathenism or the Manichees, there arose a schism among them, and they anathematized one another in their writings. When then Eutychius heard of these people, he immediately joined himself unto them, and was imbued with their sentiments, and became one of them, and began composing a work in their defence, and drew up and published books, until

h Or, perhaps, 'but are made into others.' Eustathius, in his life of Eutychius, gives no explanation of John's assertion, that originally he was a follower of Paul of Samosata, if such is the

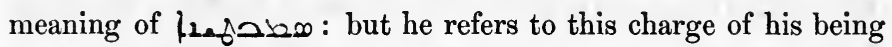
an Athanasian, and says that he held no more than the fathers generally, in whose writings he was deeply versed, and of whom Gregory said, 'Despise the flesh, which passes away; care for the soul, which is immortal.' And Basil, 'Would that I might put off this heavy cloak, and receive a lighter one.'

The ill fate of Eutychius' books evidently was a favourite topic with our author, as he tells the whole story again in lib. iii. cc. $17, \mathbf{1} 8$. 
his bishops and clergy were alarmed, and resisted him; and after much diccussion, he was ashamed, and held his peace, and gathered in his writings, though he still continued of the same opinion.

II. 37. Eutychius, however, himself ascribed the ill success of his books to the machinations of the orthodox: and though the supposition was unfounded, it led him to entertain an implacable animosity against them, and to set his face to exterminate and destroy them. He let loose therefore upon them, on the occasion of the celebration of their love feasts, the more violent members of his party, such as the officials of the ecclesiastical courts, and soldiers and civilians and clergymen and guardsmen ${ }^{i}$, who attacking them, not like Christians, but like murderers and barbarians, dragged them with open violence to prison, overturned their altars, threw down their oblations, and poured out the consecrated wine, while the sacred vessels, and every thing else of any worth, which they could find, with the service books, they plundered and stole: they even robbed the worshippers of their clothing and their shoes, and any thing else they found of value they took, without despising even trifles. And when they had stolen all they could, they dragged them away, and all whom they found

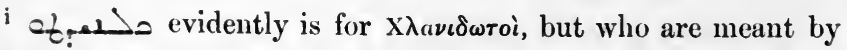
the term is uncertain : as Chlanis, teste Du Cange, is however used for Chlamys, I imagine they may possibly be the young officers of the royal bodyguard, generally called Chlamydati. 
in their company, to prison, and confined them, rich and poor together, and only let them out to make room for a fresh crowd, as similar scenes were repeated every day. But these proceedings brought general disgrace upon Eutychius and his party, because, like heathens, they had thrown down and trampled under foot the bread consecrated on Christian altars, and even cast it into the fire and burnt it. And all these evils were done without restraint, until no congregation openly ventured to celebrate public worship throughout the whole city.

The cause of all these wrong doings was a cer- II. $3^{8 .}$ tain Fravian, or Flavian k, originally a slave of Andrew, the queen's pursebearer, who at the commencement of the persecution left the palace and his office, and went forth for the truth's sake, and was plundered, and imprisoned in the monastery of Dalmatus, but retained his constancy unbroken. In his household was a slave of barbarian parentage, whom he had carefully brought up, and trained to be his scribe; and he was a believer and all his house. In process, however, of time he apostatized and conformed to the tenets of Eutychius, by whom he was employed as an informer, and troubler of the believing clergy and their congregations. Taking therefore with him a troop of officials and

k The change of Flavianus to Fravianus is not unusual in the Græcising of Roman names. Thus in the lists of the patriarchs of Constantinople we find Phravitas, i. e. Flavitas, still better known as Flavianus II., patriarch A. D. 488-490. 
guardsmen and civilians and clergy, he went about laying hands on every body, and dragging them to prison, after plundering them barbarously, and spoiling them and taking from them all they had. To escape from him, many gave him large bribes; for though a man crept and hid himself in a needle's eye, as the proverb is, he was sure to creep in after him by some stratagem or other, and seize him, and plunder and imprison him. And thus he became the tempter and Satan of all the priests and congregations, and of all the believers in the capital, and of us too with the rest; and, in short, it would be impossible to enumerate the evils wrought by this man against the whole orthodox church.

1I. 39. Among those who endured this persecution with exemplary firmness was a young nun. She was one of two sisters whose mother died while they were infants, and their father placed them in a convent; and dying soon after, he left them, that is, their convent, whatever he possessed. And in process of time they grew up, and had just arrived at womanhood, when John's persecution broke out, and subsequently that of Eutychius: and as they obliged every religious house to receive the sacrament at their hands, they took the sisters, upon their refusal, and placed them in separate convents: but they both stood firm as adamant, and especially the elder; upon which they inflicted upon her every kind of torture and pain, and close confinement, 
and hunger and thirst, as being the elder of the two, and glorying and fervent in the faith. But she rebuked and reproached those in whose convent she was confined, and said, 'Ye and your priests, and all your party, are aliens to the Holy Trinity, and hold instead of it a quaternity of persons, like the synod of Chalcedon, which makes a pretence of excommunicating Nestorius, but really and truly holds his view, and acknowledges two natures, just as he did, and as you also do, and all who agree with it.' And as they could not refute her arguments, they went and accused her to the bishop, and said to him plainly, "Unless you give orders for the immediate removal of this tempter, know for certain that we must all quit our nunnery ; for it is impossible to endure her scoffs and contumelies, or answer her arguments.' He therefore sent to the exarch, or officer who had the general oversight of the monastic institutions, commanding him to go and examine her, and severely chastise her; and then eject her, and send her to a convent where their discipline was more severe, with directions to torture her until they made her submit. The exarch accordingly deputed his visitor to try the case, and on his arrival they began to accuse and threaten her; but she of her own accord laughed at them, openly expressing her contempt, and saying, 'Why do ye heathens and murderers threaten a poor weak girl like me? If ye go no further than threats, and do not at once murder me, according to your 
custom and that of him who sent you, I do not count you as men, or even as living creatures.' Upon this, they beat her in anger with a staff until they were tired: but she only derided them the more, and anathematized them, saying, ' $O$ you heathen persecutors and murderers of Christians!' and urging them to kill her, she said, 'You are heathens and not Christians; for' Christians do not persecute Christians : but you shew yourselves to be heathens, and that you do the work of heathens.' And as they could not answer her, they dragged her away and imprisoned her in another numnery, leaving orders that they should torture her severely. But when but a few days had passed, they also began to cry out, and try to get rid of her. And so she was removed to one convent after another; and when none could break her spirit, Eutychius gave orders that she should be brought to him in the church. But when the exarch's people heard of the patriarch's intention, they went to him, and said, 'Know, my lord, that if you let her enter your presence, and do not first cut out her tongue, or strike off her head, there is no reproach or ridicule that she will not freely utter to your face: for even when flogged and scourged, she only grows the more vehement, being ready and eager to suffer death.' Finally, however, she was brought to the church, and many attacked her one after another, and multiplied their threats and denunciations; but she regarded them no more than as if they had been 
so many dead persons, and reproved them at great length. And so they were all everywhere vanquished by her, and finally let her return to her own numnery. And thus she was the cause of the whole convent being unmolested: for they never ventured again to attack them, being unwilling' to encounter her, and saying, 'If this one sister of that convent has endured without flinching all these trials, since they are all alike, who will ever be able to overpower them?'

Not satisfied with these attacks upon their per- II. 40. sons and their property, Eutychius endeavoured also to weaken the argumentative position of the orthodox by making a change in those parts of the Liturgy which favoured their views.

Carrying himself then proudly, in this as in every thing else, and wishing to prove himself a theologian, he formed the purpuse of doing away with and abolishing the immemorial custom of the ministrations in the churches, and establishing a corruption of his own composing : he therefore drew up an antiphon for the Thursday in Passion week, and had it copied on tablets, and sent it to all the churches, with orders that the ordinary antiphon should no longer be used, but his own substituted in its place, adding threats and menaces against such as should still venture to use the former one in preference to his own.

But not only the clergy of all the churches and convents and monasteries, and monks and nums, were in alarm and commotion, but also the whole city and senate: and a general riot was on the 
point of breaking out, not only on the part of the churches and monasteries, but also of the people of the city. And at length the matter reached the king's ears, to whom it was told by one of the senate: and when the bishop came in haste and hot anger, to complain to the king of these things, he rebuked him very sharply, and said, 'How long will it be before you can moderate yourself, and live in quiet? For see, you have agitated and disturbed the whole city. For how could you imagine that you had authority to change our ancient customs? Look to yourself, that they do not stone you.' To this he replied: 'I assure you, my lord, that what I have composed is far fitter for the occasion than the old one.' But the king said, 'Know that if you had brought your antiphon down from heaven, we would not admit it. Go, and keep to your church: and follow in it what has been established by the ancient fathers.' And so his vehemence was checked, and his menaces gave place to a discreet silence.

II. 52. Of a similar change attempted in the Trishagion' our author gives some more particulars in

1 The Trishagion was a hymn originally taken from Is. vi. 3, but subsequently remodelled till its words were, ' $\mathrm{O}$ holy God, holy mighty One, holy Immortal, have mercy upon us.' Into this Peter the fuller, patriarch of Antioch in A. D. 460, introduced the words, 'that wast crucified for us ;' with the express purpose of supporting the views of the Monophysites, and succeeded in the patriarchate of Antioch, when their views were for many years in the ascendant. 
the last chapter of this book, wherein he says, that as we have mentioned above the excellent Eutychius was a very eager opponent of the phrase, 'That wast crucified for us,' and wrote strict injunctions to the bishops everywhere to omit this confession from the churches of the cities over which they presided: and at the consecration of all new bishops he exacted a promise that they would cause its entire suppression in their dioceses. But upon their endeavouring to obey this command, the people everywhere, both in the cities and villages, were offended and scandalized, especially in Syria, Asia, and Cappadocia, inasmuch as they had used this phrase from the first. And in many places they resisted, and rose up, saying, "Though we be hacked to pieces, and burnt, yet will we not deny the God Who was crucified and suffered for us.' And this strife and quarrel continued in every province of the empire even after the death of Eutychius.

In this persecution our author suffered chiefly II. $4 \mathrm{I}$. in the unjust legal proceedings taken against him respecting some property. For this, John, generally known as Superintendent of the heathen, and who was bishop of Ephesus, after all the trials and imprisonments and persecutions and banishments which he had endured, was required to give up the writings of an endowment which had been granted him by Callinicus, chief officer of the king's household, and a patrician. But John, upon receiving it, had expended upon it considerable sums, having both restored the buildings, 
and built a church, and erected three cisterns; and finally, had dedicated it as a monastery. But when the persecution broke out, in the time of John of Sirmin, he took from him the monastery, and put into it monks in communion with Chalcedon, and sent its founder into exile to an island in the sea. And when upon John's death he returned from exile, Eutychius demanded of him the deed of gift and all the other writings by which he held the property; and not only so, but also the furniture, and service books, and every thing else belonging to it. And when John resisted, after a lengthened persecution, he finally arrested him, and cast him into prison, and took from him by force all the papers upon which he could lay hands. And while he still lay in prison, he assembled a troop of officials and laymen to try him for refusing to deliver up the furniture. But John was strengthened by the grace of God, and said to them, "What furniture and what things demand ye? Is it aught that ye gave, or that some one else gave? He who gave me the furniture would be the fitting person to demand it back. For lo! all the deeds of the endowment that were in my possession ye have already taken away by fraud and violence, without fear of God. Read then, and see for yourselves: is there so much as the name of monastery there, or any mention of furniture as received by me? If there be, then let it be required of me. For I it was who, to my misfortune, made it a monastery. But if the name do not occur, then was it no mo- 
nastery when first it came into my hands.' And so, by the grace of God, he made them ashamed of themselves, and they said nothing more to him upon this point; but they took away from him the right of having five loaves at each public distribution of corn ${ }^{\mathrm{m}}$, which had cost him three hundred darics, saying, "These at all events you bought in the name of the monastery.' And even then they did not restore him to liberty, but kept him in prison, until he formally resigned the endowment, and so he was set free.

The two succeeding chapters contain the information respecting Paul, metropolitan of Aphrodisias, which we have given above in its proper place: and then follows an account of Deuterius, John's fellow labourer, and subsequently the successor of Paul as bishop of the orthodox communion in Asia. He is spoken of by his former coadjutor in terms of sincere affection, as follows : - This Deuterius was a man of industrious and II. 44 . upright habits, who from his youth to old age uninterruptedly, through a period of five-and-thirty years, was fellow-labourer with John in instructing the heathen in the provinces of Asia, Caria, Phrygia, and Lydia, where together they built ninety-nine new churches and twelve monasteries: and throughout this time John confided in him, and trusted in him more than in all besides. When therefore he grew old, and became the victim also of persecution, he appointed Deu-

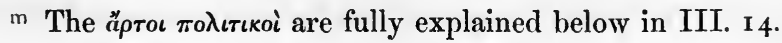


terius in his place as bishop of the orthodox in Caria, and intrusted to his charge the churches and monasteries there, among which he laboured, visiting and strengthening them all, until his death, which happened at Constantinople. For he was greatly assisted by Divine grace, which enabled him to discharge efficiently and zealously and manfully the painful duties of his office: and when the synodites pursued him in hopes of getting him into their power, that they might treat him as they had done Paul of Aphrodisias, and substitute him in the place of the other Paul of Antioch, the Lord did not deliver him into their power: and so he fought unto the end the good fight, and arrived at a prosperous old age.

The next chapter treated of the apostasy of the Cappadocian monks, whom Narses had received temporarily into his convent in Bithynia(l.i.c. 39), and we have therefore arranged it with the rest of their history: and possibly the next chapter should have accompanied it, as it is a lament over the confusion and uncertain creed which was occasioned in the monasteries by the persecution, and of which they were an example. As, however, it belongs chronologically to the present time, it has been allowed to retain its original position; and is as follows:

II. 47. Upon the visitation of the nunneries, great and small, the inmates were compelled to receive the communion at the hands of their persecutors, and such of them as submitted, continued to re- 
side as inmates; but some of those who refused, subsequently returned, and again commenced residence. There were therefore now two parties in the nunneries; those who had submitted, and those who had not; and both joined in the whole service, except the actual partaking of the Eucharist. And even when the elements were consecrated by the clergy, and during the actual participation, all had to stand and join in the services, and perform the whole office in common, without venturing to separate one from the other. Such, however, as did not actually partake were allowed to have a special service for themselves, and receive the Lord's supper at the hands of orthodox presbyters. And because of the urgency of the times, they were compelled to submit to these regulations, or they would have been summarily expelled and dispersed; and the chiefs of the orthodox were obliged to keep quiet, and overlook these things, or orthodoxy would have come to a speedy and utter end.

There were at that time at Constantinople II. 48 . some elephants, whose conduct excited wonder and astonishment. Now it may easily happen that those who are given to ridicule will find only an occasion for derision in lighting upon a narrative of the acts of irrational animals in our histories: but we do not record it without reason, or, so to say, foolishly, but first of all for the glory of God, and secondly for the refutation and conviction of heathens and Jews, and of all other 
mistaken persons, who deny the cross, and reject the dispensation of our Saviour, the sign of which is the cross upon which it was wrought.

These elephants then were part of the spoil captured after a victory, which God gave the Christians over the accursed people of the Magians; and being sent to Constantinople, continued there a long time; and whenever they passed a church, the foremost elephant, who was marching in their front, turned round towards the east, and bowed down his head and trunk, and made obeisance; and then, raising up his trunk, he waved it round, and made the sign of the cross, and signed himself, and so passed on. And next, the second would raise his trunk, and act in the same manner; and the rest in order unto the last. And this we have often seen with our own eyes, while we wondered and praised God, Who had given the knowledge of Christianity even to dumb animals, for the rebuke of those who have the gift of reason, and yet neglect Christianity, and despise the grace of Him Who has saved our sinful race.

And there was another similar practice of these animals equally wonderful and astonishing, and which they never failed to perform whenever the customary horseraces were held in the Hippodrome. For these elephants were always brought in, each with his conductor on his neck; and standing in the Hippodrome opposite the king, they bowed down, and made their obeisance to him to the best of their ability, and as far as 
their nature would permit. And then each one of them made the sign of the cross with his trunk, and signed himself before the king: while the crowds assembled there were amazed and astonished to see them use the sign of the cross exactly like men. And finally, the king made them presents, and they retired.

Another extraneous subject is an account of a II. 49 . great fire, which, towards the close of Tiberius' reign, and the commencement of that of Maurice, broke out in the very centre of Constantinople, and derastated a great portion of it; so that many estates, some large and some moderate and some small, were simultaneously destroyed, and their owners, even if they escaped with their lives, were stripped and beggared of all they possessed, and with their own eyes saw it fall in one day a prey to the flaming fire.

Now when men of practised learning fall in II. 5 o. with these narratives, they will possibly blame the writer, because it may so happen that the same fact is recorded in a confused and disorderly way in several different chapters; be it known, then, in our defence to such as are inclined to find fault, that most of these histories were written at the very time when the persecution was going on, and under the difficulties caused by its pressure: and it was even necessary that friends should remove the leaves on which these chapters were inscribed, and every other particle of writing, and conceal them in various places, where they sometimes remained for two 
or three years. When therefore matters occurred which the writer wished to record, it was possible that he might have partly spoken of them before, but he had no papers or notes by which to read and know whether they had been described or not. If therefore he did not remember that he had recorded them, at some subsequent time he probably again proceeded to their detail; and therefore occasionally the same subject is recorded in more chapters than one: nor afterwards did he ever find a fitting time for plainly and clearly arranging them in an orderly narrative.

Of this we have an instance in the two next chapters, one giving an account of the lapse of Eutychius into the heresy of the Athanasians, and the other of his attack upon the Trishagion, both of which belong to previous portions of the history.

End of the Second Book of the Narratives of the Church, in which are contained fiftytwo chapters. 


\section{BOOK THE THIRD.}

INASMUCH then as the events which took place III. I. at the commencement of the reign of the victorious king Justin II. have been sufficiently detailed by us in the previous part of our history; and that originally he was anxious to make unity, and mild and peaceable to the whole body of believers for the first six years of his reign, but then changed, and took part in a persecution carried on in a violent and uncanonical manner, of which in the two former books we have given a few details out of many; and inasmuch as we then gave a slight account, but covertly, of the chastisement which came down upon him from Heaven for his soul's benefit, and to abate the violence of the evils about to fall upon him, desisting from an exact detail, lest we should be thought to speak in scorn or derision of the high office of royalty, in venturing openly to describe and record the pitiable smiting justly inflicted upon him by God; but have been rebuked for this silence; we therefore now think it right briefly to record what took place, that those may fear who in future times shall be girt with high and princely power, and that the dread judgment of God upon king Justin may be recorded, and its remembrance engraven on the heart of all men for their admonition. 
III. 2. For the merciful God, Who willeth not the destruction of His creatures, and Whose providence watcheth over the lives of men, when He saw that king Justin was using his royal power for things excessive and alien to all piety, visited him with chastisement, lest when the measure of his sins was full, it should sink him in utter perdition. For He beheld him wickedly shedding the blood of innocent men, and given up to the plundering and reckless spoiling of their goods, unrestrained by the thought of the fear of God, and gathering and heaping up unrighteous wealth. beyond what most of his predecessors had done : and finally, not content with stirring up God to anger by crimes such as these, he betook himself also to the persecution of Christians severely and pitilessly, and without natural mercy, levelling the altars of the orthodox in bitter wrath by the hands of the bishop John, and every where breaking down their churches, and seizing their priests and bishops, and oppressing them, and vexing them, and confining them in prisons, and guardhouses and monasteries, and in various cruel hospices, being men aged and weighed down, and infirm with years; so that many of them even fainted, and departed from this present life, being exhausted by the miseries and tortures of their bonds, and their strict and bitter and severe imprisonments. For many of his evil deeds have never even been mentioned by us, nor are we willing to record or bear witness of much of his conduct, so iniquitous was its character: but it 
did not escape the justice of God, Who yet, because He was gracious unto him, that he might not utterly perish, but being rebuked, might be stopped in his wicked course, sent upon him, in the language of Scripture, 'indignation and wrath Rom.ii. 8. and tribulation.' And He sent it by means of an evil angel, who suddenly entered into him, and took his form, and domineered over him cruelly and fearfully, making him an example of the terribleness of their malice. For suddenly it destroyed his reason, and his mind was agitated and darkened, and his body given over both to secret and open tortures and cruel agonies, so that he even uttered the cries of various animals, and barked like a dog, and bleated like a goat; and then he would mew like a cat, and then again crow like a cock: and many such things were done by him, contrary to human reason, being the workings of the prince of darkness, to whom he had been given up, and who had darkened his understanding, and taken it captive, and who wrought in him every thing that he did.

At other times the evil spirit filled him with agitation and terror, so that he rushed about in furious haste from place to place, and crept, if he could, under the bed, and hid himself among the pillows $^{\mathrm{a}}$; and then, when the horror came upon him, he would rush out with hot and violent speed, and run to the windows to throw himself down. And his attendants, in spite of their re-

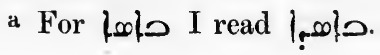


spect for him as king, had to run after him, and lay hold of him, to prevent him from dashing himself down and being killed: and the queen was obliged to give orders for carpenters to come, and fix bars in the windows, and close them up on the whole of that side of the palace on which the king lived. Moreover they selected strong young men to act as his chamberlains and guard him; for when they were obliged, in the way I have described, to run after him and seize him, as he was a powerful man, he would turn upon them, and seize them with his teeth, and tear them: and two of them he bit so severely about the head, as seriously to injure them, and they were ill, and the report got about the city that the king had eaten two of his chamberlains. And sometimes, as was said, they had even to tie him up, while he screamed and howled, and uttered words without meaning: but if they said to him, The Bogle ${ }^{b}$ is coming for you, he would be still in a moment, and run away, and hide himself; and any name which they mentioned was enough to frighten him, and make him run away, and be quiet, and creep under his bed. And there were other things more disgraceful than these, and more lawless, which were openly spoken of without fear by every one in the city. These few which we have here recorded we had upon the testimony of many: for they were the constant

b Literally, Chorth the son of Gabolo, that is, Harith the son of Jabal, a common name at this time among the princes of the Arabian kingdom of Hirah. 
subject of conversation. He continued then, not for a few days only, but for five years, thus tried and tortured: and our brief account of his state we have given upon the authority of others; for we were neither near, nor eyewitnesses of it; but the whole senate and city, natives as well as foreigners, bear witness to the truth and exactness of our details: and that much besides happened, too unseemly to be recorded in writing.

In this disordered state of the king's intellect, III. 3 . those about him devised various kinds of amusements, both to divert his attention, and in the hope of restoring him to the use of his reason. The most successful of these was a little wagon, with a throne upon it for him to sit upon, and having placed him on it, his chamberlains drew him about, and ran with him backwards and forwards for a long time, while he, in delight and admiration at their speed, desisted from many of his absurdities. Another was an organ, which they kept almost constantly playing day and night near his chamber; and as long as he heard the sound of the tunes which it played he remained quiet, but occasionally even then a sudden horror would come upon him, and he would break out into cries, and be guilty of strange actions. For once, when the patriarch came to visit him, and drew near and made his obeisance, seeing that the king was agitated, he signed him with the sign of the cross; upon which he raised his hand, and struck him so heavy a blow on the head, that the patriarch reeled and fell on his 
back a good distance from him, while the king exclaimed, 'An evil end be thine: go and sign thyself, that thy own devils may get out of thee.' The rest meanwhile took the bishop and raised him up; but it was some time before he returned to his senses, being stunned by the severity of the blow. At another time, as it was impossible for the patriarch not to pay the customary visits to the palace, upon his entering cautiously, and on his guard, the king, at the sight of him, fell into a fit of laughter, and jumping up, laid hands upon him, and took from his shoulder his mitre, which is the insignia of the episcopal office, and spread it out, and put it upon his head, like a woman's hood; and looking at it said, 'How well it becomes you now, my lord patriarch : only you should put on some gold lace, like the ribands which the ladies wear upon their heads.' At another time, standing at a window overlooking the seashore, he began to cry like those who go about hawking crockery, 'Who'll buy my pans?' And many other such things he did which it is impossible to relate, and which were wrought in him by the devil, to whom he was given up; and which were the common talk of every city and village, and house and street, and tavern, within and without Constantinople: and even upon the way all men talked of them with much wonder and astonishment.

III. 4. When then the king was chastised by this bitter humiliation and trial, many thought and spoke of it in different lights : and first of all his wife, 
the queen Sophia, was not only not chastened or alarmed by the affliction and punishment which had overtaken her consort, but was rather elated, and said; "The kingdom came through me, and it has come back to me: and as for him, he is chastised, and has fallen into this trial on my account, because he did not value me sufficiently, and vexed me.' Such, however, was not the general opinion; but she was considered as having spoken wickedly, as we shall shew in what we have afterwards to record. What, however, men generally did think, though they did not venture to express it, was, that God had inflicted upon him this visitation for three chief reasons; first, because of the innocent blood that he had shed; next, because he had persecuted Christians, and had inflicted torments and miseries, and bonds and close imprisonments, and exile, upon priests and bishops, and the believers generally, both men and women; and thirdly, because of the manner in which he had plundered and spoiled men's goods, and not permitted orphans to inherit their fathers' property, so that the cry of orphans and widows rose up before the Lord, together with his other evil deeds; and therefore He was angry with him, and delivered up his kingdom to others, while he was yet alive, and saw it with his own eyes.

When king Justin had continued in this state III. 5 . of trial and sickness, and oppressed with other evils, for a period of five years, and the sixth had begun, being thus chastised by the operation of 
the devil, all business being neglected, and matters of state in confusion, and wars with the barbarians coming in quick succession in every quarter ", the whole senate took counsel with the queen to make the God-loving Tiberius king, and appoint him as Cæsar to conduct in Justin's stead all matters of state. And to this Justin himself consented; for there were intervals, though coming irregularly, when he recovered the use of his senses, and could converse upon matters connectedly. After a long consultation, therefore, with him, they chose and appointed Tiberius as Cæsar, as for a long time he had been Justin's keeper, even before he had come to the crown. Upon Justin's summoning him, therefore, and solemnly investing him with the dress and insignia of royalty, an angel, as he himself acknowledged, appeared to him, and stood by him, and dictated in his ear the words with which he was to address Tiberius Cæesar: and he began to speak unto him words of wonder and astonishment, as though his mind had never sustained any injury. For weeping, and with his words broken by tears and sobs, he said, ' $O$ son 'Tiberius, come and take the kingdom of the wretched Justin, who has made God

c The final disaster which rendered the appointment of a Cæsar indispensable was the capture of Dara by Khosrun, and as a necessary consequence the devastation of all the provinces of the East up to the walls of Antioch : of which an account is subsequently given in the sixth book. Khosrun is said to have returned from this expedition with a quarter of a million of Christian captives. 
angry, so that He has rejected him, and cast him out of his royal estate while still living. Come, my son, enter upon thy office, and displace him who has set his Creator at nought, that Creator Who gave him the kingdom, from which his own eyes now see him rejected and fallen.' And when he thus spake with a loud voice in the presence of the many thousands assembled there, all who heard his words broke out into bitter weeping and loud sobs; and especially when he turned round, and, waving his hand towards the soldiers posted there, said to them with a loud voice, - Open, my children, your ranks, and let whoever will come in, and see the wretched Justin stripped and fallen from his kingdom, because he has provoked to anger and wrath that true and eternal King Whose empire passeth not away, and Who had bestowed upon him, unworthy as he was, the kingdom. And now, 0 Tiberius, let my fate be to thee a terror, and alarm, and trembling, before the Lord the eternal King, that thou beware of Him, and stir Him not up to anger by thy evil deeds, as I have done, by those deeds of mine, which have brought down upon me this severe and terrible chastisement. For lo! while I yet live, I am stripped and ejected from my kingdom, because I have acted iniquitously therein. Beware, lest this apparel and royal dress lead thee astray, as it has led me, and fill thee with pride and error and presumption, and bring upon thee the wrath of Heaven, as it has upon me, and thou too be stripped, and fall from thy kingdom, 
as I this day. Look, my son, at him who stands by me, and whispers to me in my ear, and teaches me all those things which I speak unto thee, and teach thee, and command thee and admonish thee; and be thou sure and convinced, and aware within thyself, that what is now spoken to thee by me is not of me, but comes from this angel of God. And if thou, or any one besides, seest him not, behold he stands by me, and teaches me those things which I say unto thee, that thou mayest fear, and be afraid at the dread sentence of justice decreed against and inflicted upon me, as, lo! thou and all men see. For because I have not kept God's commandments, He now strips and ejects me from my kingdom, and delivers it unto thee. Look therefore on me, my son, and from my case take an example of terror and alarm for thy own heart, at the sentence which has gone out against me, and let it not be lifted up unto evil deeds, such as I have done, lest wrath be sent down also upon thee from Heaven, as it has now upon me, and thou too be cast out of thy kingdom. Beware, therefore, lest thou give way to wicked men, who will counsel thee unto evil, and lead thee astray as they have led me astray, until I have made God angry by all my doings.' These words, and many more to the same effect, but which we have omitted because of their too great length, were spoken by the king, in sorrow and tears, with a loud voice, in the presence of all men: while the illustrious Tiberius threw off his robe, and fell on his face to 
the ground at the king's feet, and gave unrestrained way to his lamentation ${ }^{d}$ with tears and sobs of bitter sorrow, in which the whole senate, and all who stood around joined, when they heard these things, and saw both him who was giving up the kingdom, and him who was summoned to receive it, the prey of such deep anguish. And when they took hold of Tiberıus, and raised him from the ground, he fell again on his face with a loud wail. And at this, all the multitudes at once, with one cry of mighty suffering, and from their hearts, lamented with loud voice, nor could any one check or restrain his tears on hearing the words which the king, weeping at his humiliation, spake. And finally, he gave orders, and they raised Tiberius up, and again he addressed him in language broken by sobs : and then he invested him with the insignia and dress and emblems of royalty, and said, 'Henceforward be thy name called Constantine; for in thee shall the kingdom of the great Constantine be renewed.' The rest, want of space alone compels us to omit. The day of the appointment of Tiberius as Cæsar was the seventh day of the earlier Conun, in the year eight hundred and eighty-six, on the day of the preparation, in the morning. (Friday, Dec. 7, A. D. 574.)

So firmly persuaded were all men that these words were not spoken by the king himself, but by an angel of God, that when at length pictures

d Literally, ' bellowed like a bull.' 
were set up in honour of Tiberius and Justin, an angel was painted standing between them, and with his mouth at Justin's ear : and that the fact was really so, was firmly received by every one. The words themselves were taken down in shorthande by many who were present, and at once committed to writing; for there were numerous scribes present taking notes: but their full and exact recital would exceed our limits.

III. 6. Justin survived the appointment of Tiberius as Caesar for four years, and hopes were long entertained of his recovery, chiefly because of the recurrence of lucid intervals, during which he could be propped up in his chair, and shown to the people, and even taken to the entertainments of the Hippodrome in the morning: and sometimes he was sufficiently well to give audience, and receive the salutations of the senate. Sometimes also he distributed largesses to the people, for which purpose they put money into his hand, which he scattered, with the help of his attendants, who guided his arms : but then he would again relapse into his former imbecility, to which were added other trials, especially the painful disease of strangury: so that upon the whole his health constantly declined.

During this period the affairs of state were entirely directed by the God-loving Cresar, especially the wars with the barbarians and the Persians;

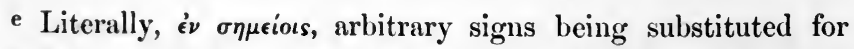
words according to the method of stenography existing in those days. 
but whenever Justin was capable of it, he took counsel with him; and if he spake any thing sensibly, it was done. But as time passed on, their hopes of his recovery were disappointed, and his maladies rather grew more and more aggravated, till his pain was such, that he often called out, and besought them to bring a sword and kill him; for death, he would say, is better for me than a life of such anguish and agony: and at other times he would bid them throw open the gates of the palace, that all who wished might enter, and see the king asking for death, and desiring it rather than life, and death denied him. And when afterwards the pain of the strangury increased, and he was tortured by stones which obstructed the bladder, and physicians came to cut them away, they requested him, after the usual cowardly manner of physicians, to take the lancet into his hand, and give it them $^{\mathrm{f}}$ : and he in answer begged them to shew him no mercy, but let him depart from life : and said, 'Fear not: even if I die, no harm shall happen unto you.' A deep incision was then made in both his groins, and the whole operation so barbarously performed, that he was put to extreme torture: nevertheless, in the midst of his cries, he said, with a loud voice, 'Just are thy judgments, $\mathrm{O}$ God; for all the sins and wickednesses which I committed with my body are

i By this action was signified the king's consent to the operation, so that if he died under it, they would not be punished. 
openly requited in Thy anger upon the members whereby I wrought them.' His death was now certain; and being fully aware of it, he sent for the Casar, and charged him, and admonished him in many words, saying, ' I, my son, am dying : go now, take the royal crown, but be on thy guard, that thou be not guilty of $\sin$, and provoke God to anger: and consult for the good of the kingdom of the Romans.' Accordingly, Tiberius received the crown on Monday the twenty-sixth of September, in the year eight hundred and ninety (A. D. 578); after which, Justin survived for nine days, and departed from this world on the fourth day of October that same year.

III. 7. After the death of Justin, the queen Sophia continued to dwell with Tiberius in the palace, Ps. xlix. and he showed her the greatest honour, "though 20. she being in honour understood it not,' as Scripture says. For before they made him Casar, they had required from him an agreement confirmed by solemn oaths, that in case of the king's death, the Cresar should pay every honour to Sophia, and not do her any evil. And this he scrupulously observed, and on the king's death took her to dwell with him in the palace, saying unto her, 'You are my mother: dwell here, and command me whatever you wish.' When, however, he requested permission for his wife to come and dwell with him, she was displeased, and refused her consent. For even during Justin's life, he had said to her, 'Let the Cresar's wife come and dwell with him: for he is a young man, and the flesh 
is hard to rule :' but she had answered him with scoln; 'Fool, do you wish me to make myself as great a simpleton as yourself? you! who have invested your slave with the insignia of sovereignty!' And then she vowed with oaths, 'I, as long as I live, will never give my kingdom and my crown to another, nor shall another enter here as long as I am alive.' The idea therefore was given up, and during the four years which elapsed between the appointment of Tiberius as César and Justin's death, the Cæesar's wife was never suffered to enter the palace, and her husband was compelled, on bringing her to Constantinople, to give her and his two daughters the house of Hormisdas as a residence, as it was situated just below the palace. And constantly he went down and spent his evenings with them, and returned early in the morning to the palace. And it is said, that proposals were made to him, both through another person and through the patriarch, that he should put away his wife, and marry either Sophia herself or her daughter, who was also then a widow. But he was very indignant on hearing their proposal, and said, according to the current rumour, 'Will it please God, as well as you, for me to leave my wife, by whom I have had three children, and who took me to share all she had when I had nothing? and now that God has raised me to power, am I to leave her and take another?' And thus he refused to listen to their words, and commit this iniquity.

The name of the Cæsar's wife was Ino, and she III. 8. 
had previously been married to a Roman who held some military office at a place called Daphnudii Castra ${ }^{\circ}$, and to whom she bore a daughter and this daughter they betrothed to Tiberius, while he was still a civilian and a Roman merely. Soon after the betrothal, the father died, and as the damsel did not long survive him, the mother remained a widow and childless. And Tiberius, as the will of Providence apparently had ordained, took the maiden's mother to wife, and had by her three children. And when he sent for her, and made her dwell in the palace of Hormisdas, she was in constant terror, considering her life in danger: and as long as she remained there, no one ventured to visit her. For the wives of the senators met to consider it, but were afraid to go and make their obeisance: and, finally, they asked Sophia, whether it was her command that they should pay their respects

g I imagine this to be the place mentioned by Stephanus By-

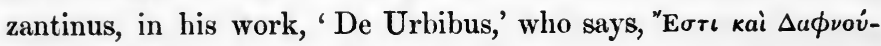

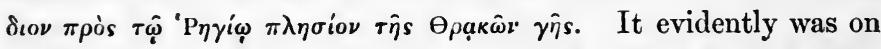
the seashore, and therefore cannot be the Daphnudium mentioned by Fabricius, as the seat of a bishopric in Phrygia Salutaris.

The word for civilian is literally pagan: but it had come to bear this interpretation among the jurisconsulti at Constantinople. Similarly in the Acta Martyrii, c. I. Tarachus, on being asked what was his profession, says, 'I was a soldier; but on becoming a Christian, I chose to be a pagan, i. e. civilian,

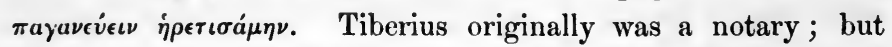
rose subsequently to the high office of Comes Excubitorum, and so paved the way to his adoption by Justin. 
to the Casar's wife? fearing lest otherwise they should incur blame. But she scolded them sharply, and gave them an angry answer, saying, 'Go, and be quiet: it is no business of yours.' And as no one ventured to oppose her, the Casar's wife made her escape, and fled from the city back to Daphnudium; and when she fell ill there, the Cresar was obliged to go backwards and forwards to see her.

Upon the death however of Justin after hav- III. 9. ing invested Tiberius with the royal crown, as we have mentioned above, when Tiberius made the request that his wife might be sent for, to share the crown with him, though Sophia was by no means pleased, yet it was impossible for her to offer any opposition. Accordingly the commander of the pratorian guard, accompanied by a large number of men of senatorial rank, with numerous row-boats, and a great retinue, set out to fetch her: and starting with great pomp, they arrived at Daphnudium, and informed her of the purpose of their visit; upon which she answered, 'Come in the morning, and we will start immediately.' Upon receiving this reply, they prepared to remain there for the night, and a temporary abode having been erected for them, they entered it, and lodged there. But her real purpose was very different: for having sent immediately for one of her boatmen, she said, 'Go and get a boat ready; for I wish to send forward an answer by you, without any one knowing it.' And at midnight, when the 
boat was ready, she took her two children, and one boatman only, and went on board with them by herself, without any companion, and started for the capital, leaving it to others to say to the commander and his retinue, "Do not linger" here; she whom ye want was at the city before sunrise.' On being informed of this, they were greatly annoyed, and returned to the city, ashamed at having to come back without bringing her. She meanwhile on her arrival was conducted immediately to the palace, and the patriarch met her there, and the whole senate and the king, and invested her in the robes and other insignia of royalty. And from the palace she proceeded in a covered litter to the church, attended by the senate and her chamberlains, while the blue and green factions stood prepared each to greet her, the blue naming her Anastasia, while the green shouted Helena; and so fiercely did they contend with rival shouts for the honour of naming her, that a great and terrible riot ensued, and all the people were in confusion. She meanwhile entered the church, and made adoration, and returned to the palace as queen ${ }^{\mathrm{h}}$.

h The account in Theophanes, though full of inaceuracies, confirms generally the narrative here given. He says, that when Tiberius had been crowned, on entering the Ludi Circenses, the populace demanded an Augusta : upon which Tiberius rose, and said, there was an empress already, whose name was the same as that of a church he pointed out : and thereupon the populace shouted Anastasia. This name apparently she afterwards bore, as Tiberius did that of Constantine. Theophanes describes the 
Of the civil events which followed, our historian says that their narration does not fall within his province; nor indeed did the preceding account, which however he recorded, because the affairs of state are closely connected with those of the church; and because there was a change of rulers; and, lastly, because the knowledge of these events may lead men to give God the glory.

The queen Sophia, after the death of king III. 10. Justin, set on foot plots without number against king Tiberius, who was now also styled Constantine, in bitter malice and wicked violence, being indignant at seeing him and his wife resident in the palace, and invested with the royal authority; and herself now in her lifetime de-

consternation of Sophia upon the news as extreme; for hitherto she had had no idea that Tiberius was married, and still less that he had two daughters. But plainly Sophia knew of his marriage soon after he became Cæsar, but hoped to prevail upon him to put his wife away. In the Remains of Theodosius of Melitene, just edited by Tafel, (Munich, 1859, p. 95), a similar aceount occurs: 'When Tiberius entered the Hippodrome, the factions demanded an Augusta : upon which he rose, and said, that the Augusta had the same name as the chureh opposite the public baths of Dagistes. Upon this, shouts were raised of 'Long live the empress Anastasia!' But Sophia was grieved in heart ; for she intended to marry Tiberius, and remain Augusta: and to her influence with Justin he owed his elevation. Tiberius subsequently appointed the palace on the Julian port for her residence, and surrounded her with a courtly retinue of elamberlains and officers, and honoured her like a mother.' 
prived of her kingdom, in which she had conducted herself neither justly nor in the fear of God; nor had she, when trial and chastisement fell upon her husband, been warned thereby, or sorrowed, or understood that she also ought to fear God, and be admonished, and become as one of the just; but was like one of those to whom Rom.ii. 5. the words of the Apostle belong, that 'because of the hardness of thy unrepentant heart, thou storest up for thyself a treasure of wrath, for the day of wrath and revelation of the just judgment of God, Who shall render unto every man according to his deeds.' And truly in her case these words were fulfilled: for because, through the hardness of her heart and her proud imaginations, she would not repent, nor fear God; she also was deprived of her royal state, though she had declared with oaths, that 'as long as she lived, she would never give her kingdom to another.' Without her consent, therefore, the kingdom was taken away from her, and given to another, and she was set aside.

They say, moreover, that when her husband's death was certain, she had several hundred pounds' weight of gold removed from the palace, and placed in a house of her own: how many they were, we will not attempt to write, because we do not know the exact truth about the matter; but the number mentioned was very large: and with them she also took other royal property besides. And when these doings reached the king's ears, he would not have her sent away 
from the palace, but said to her, 'Dwell here, and be content, as my mother: and whatever you command, we will do.' Accordingly she dwelt in the palace, but was bitter, and vexed, and out of temper, and full of grief and lamentation at her present state, to think that she was humiliated, and reduced in rank, and deserted by all men, and in her lifetime had become like one dead.

At the commencement of Tiberius' reign as III. i 1 . Cæsar, he began distributing presents lavishly to all men, so that when going to prayers, or wherever it might be, to the right hand or the left, money was scattered about on all sides as his hypatia ${ }^{i}$ : and even at sea, as he was rowed along, boats gathered round him from every quarter, and he threw them all money. This lavishness, however, displeased Justin and Sophia, and they scolded him sharply for it, and finally took from him the keys of the treasury,

i The distributing of money and doles of corn, bread, \&c. at Constantinople was reduced to a system, and formed a principal means of subsistence with large numbers of the population. Of the various methods practised, three in particular are noticed here: I. The hypatia, or money scattered among the crowds whenever the emperor appeared in public. It took its name from the consuls (hypati), as it was also expected of them. 2. The Augustaticum, which consisted of more formal presents to the chief officers, and also civilians of the city. And, 3 , the Donativum, which was a largess distributed in equal proportions among all the soldiers in the army. 
and set apart a fixed sum of money for his disposal; and so restrained him from such lavish and incessant gifts. When, however, he became king, and the power was his alone, and, as the story goes, saw with his own eyes the piles of money which Justin and Sophia had gathered, he began again spending and dispersing it largely and widely: and when, at the commencement of his reign, he was distributing his Augustaticum, or, as it is also called, 'the Donative of the Romans,' and which was never higher in ordinary circumstances than nine darics, he sent to the army in the field against the Persians no less than eight hundred pounds' weight of gold as largess. And, as though it was his object to scatter his gifts more bountifully than any one of his predecessors had done, he commanded the whole of the scholastics, or jurists, who formed a very numerous profession, to come to the palace, and made presents to them all, beginning with fifteen and twenty darics, and giving to those of lower rank ten or twelve. Soon after, he bade the physicians come, and gave liberally to them all. And next came the silversmiths, and then the bankers: and what they received depended upon what came into his mind; but if it so chanced, he would give them a pound of gold, or fifty or sixty daries apiece. And then there were the officers of the staff ${ }^{k}$, and the decani, and the troops generally. And all had

k Magistriani. 
their share: for Tiberius said, 'What good is all this gold hoarded up here, while the whole world is choked with hunger?' And thus he spent and squandered without stint: finally, however, he held in his hand, both discontinuing his donations, and not permitting any one to have access to him for such purposes.

When the God-loving Cæsar was importuned III. г 2. every day by John the patriarch about the 'Diacrinomeni ',' as the orthodox are called, he one day said, "Upon your oath in God, tell me, if they are heretics or not.' And he, hypocrite though he was, yet would not venture on oath to tell a lie, but answered, saying, 'In truth they are not heretics.' 'Are they then believers?' 'Yes, thoroughly believers: but they will have nothing to do with us and the church; and will not communicate with us.' Upon which he said, 'If, as you testify, they are believers and Christians, why do you urge me to be like Diocletian, a persecutor of Christians? Go and sit quiet: we have enough to do with the war's with the barbarians: do not also bring upon us wars with our own people.'

1 The Diacrinomeni are explained by $\mathrm{Du}$ Cange, as those who neither entirely accepted the council of Chalcedon, like the Catholics, nor entirely rejected it, like the Eutychians. But plainly this is not correct. The meaning of the term rather is, that they drew a distinction between the doctrine of pope Leo, which they rejected, and that of S. Cyril of Alexandria, to which they adhered; whereas the council of Chalcedon declared, that the two doctrines were in complete unison. 
III. 13. At a subsequent time, nevertheless, Tiberius was compelled to give way to the popular thirst for persecution, firom the following circumstances :

When, a few days before the death of Justin, he was solemnly invested with the crown, he immediately proceeded in state to the great church of Constantinople to pray : and the whole populace, together with the strangers who were there beyond numbering, assembled from every part of the city to see him; but after the usual shouts in his honour, they began to cry, 'Out with the bones of the Arians: out with the bones of all heretics, and of the heathens too: may the faith of the Christians flourish!' These seditious cries greatly annoyed him; but he said nothing at the time, being oceupied in prayer, and after making the customary offerings upon his succession to the crown, he returned to the palace. On arriving there, however, he gave orders that the ringleaders should be sought for, and immediately arrested: for he considered that their cries had reference to and were levelled at himself, as though he were in secret an Arian: and in their private thoughts many had a suspicion of this kind from the following occurrence: A short time before, a large body of Goths had been despatched to fight against the Persians; and their wives, who were left behind, requested Tiberius to assign them a church, in which they might worship according to their views, which were Arian. And he, that 
he might not annoy them, bade them return, and said, "We will see the patriarch, and talk the matter over with him.' And from this the story was buzzed about throughout the whole city, before he obtained the crown, that the Cresar was an Arian. And for this reason, those who had charge of the churches assembled, and shouted in the manner described. When then they were arrested, and brought into his presence, he received them very angrily, and said, 'What have ye seen in me like the Arians, that ye have treated me with contumely, and followed me with cries about the Arians?' Nor was it until they had made many apologies that they obtained their release. This occurrence led however to his publishing an edict, which was fixed up in the city, to the effect, that the Arians should be arrested, and the Manichæans and Samosatenians. And hence, as was sure to be the case, numbers were arrested and imprisoned by men who had no other object than openly and without fear to pillage those who had wherewith to bribe them: and large sums were given by many to purchase their freedom. And in this manner many of the orthodox suffered, being arrested, and kept a long time in close confinement : and money was demanded of them, and when they had paid it they were set free.

It is possible that this occurrence may also III. I4. have made Tiberius more lavish in his largesses: at all events, according to what was said both by himself and others, in the first year after he 
became sole monarch, he spent in this way no less than seven thousand two hundred pounds' weight of gold, besides silver, and dresses of silk ${ }^{m}$, and other things. He confined his benefits, however, to the rich and well fed, and did nothing to benefit the poor. And when Sophia was angry with him, and scolded him, and said, 'All that we by great industry and care have gathered and stored up, you are scattering to the winds as with a fan;' he said to her, 'What you collected by iniquity and plunder and rapine, J am doing my best that not a fragment of it may remain in my palace.' Even before this, he had ordered the remission of one-fourth part of the taxes in all parts of his dominions : and further, directly he became emperor, he annulled a tax of four darics, which king Justin had levied upon each right of obtaining a loaf at the public distributions of bread $n$, instituted by Constan-

$m$ Silk in a manufactured state had long been known to the Romans, but Justinian introduced the worm itself into Europe by the exertions of two monks, who having penetrated into China, and seen the whole process there, were encouraged by him to return and obtain, if possible, some of the eggs. In this they succeeded, and the production of silk soon became general in Greece ; but it long continued to bear so high a price, as for a dress to be a fit present for emperors to make.

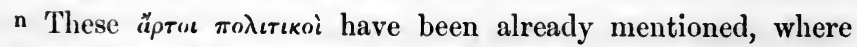
John tells us that Eutychius forced from him the right of receiving five loaves, which he had purchased for his monastery for three hundred daries; and as these rights were attached, not to persons, but to buildings, Eutychius, as we shall see, had legal right on his side, if he was justified in confiscating the monastery 
tine, and which they were then collecting; and returned the money to all such as had already paid their quota.

Another work of mercy he had done immediately upon his appointment as Cæsar : for Justin had levied upon all ships and merchants a payment equal to the value of one flagon upon each cask of wine: and this was every where

at all. The history of these loaves, as given by the Byzantine historians, is as follows: When Constantine the Great and his son Constantius, were doing their best to induce people to settle in their new city, they made regular distributions of corn there, and every person who built a house received orders, in the shape of brazen tallies, for a certain number of loaves at each distribution for ever : and this right went with the house, and as the distributions were very frequent, was a valuable property. The bread was given from certain stairs erected at intervals in the city, and not only had the householder to shew his tally, called calamus, but means were also taken to prevent their improper alienation from the house to which they belonged; and churches and hospitals, by the laws of Justinian, could neither alienate nor pawn them on any pretence whatsoever. So valuable a property was naturally taxed by poor or greedy rulers; and the very last emperor, who made the distribution, Heraclius, had but a short time before he discontinued it altogether, exacted a considerable money payment for each right. Cf. Justiniani Novel. 7. Ecclesiæ et xenodochia alienare vetantur res immobiles, sive etiam rusticum mancipium, vel panes civiles, \&c. ; and, for further particulars, Du Fresne's Constant. Christ., p. I 58, under Gradus, and his Glossary, under Panis Gradilis. It had this name, because (in the words of Prudentius) it was

. gradibus dispensus ab altis.

And there were no less than a hundred and seven flights of steps erected in various parts of Constantinople, for the purpose of distributing bread and alms to that splendid city of beggars. 
exacted so sharply that it brought in many talents. When, however, a petition upon the subject was presented to Tiberius, he immediately remitted it. And these things he did at the very commencement of his reign: and what was its character subsequently shall be shewn hereafter. And further he also made a public profession of being a Christian; for Justin had introduced in the coinage of his darics a female figure ${ }^{\circ}$, which was generally compared to Venus, and this Tiberius discontinued, and had a cross struck upon the reverse of his coins: and this act, as he himself said, was dictated to him in a vision.

III. 15. To return, however, to the persecution commanded against heresies upon the occasion referred to above; not only those against whom it was directed suffered from it, but also the orthodox congregations were swept along by its violence, as by the rush of a mighty stream. And first of all they fell upon John, surnamed Superintendent of the heathen, and bishop of Ephesus, but who had now been for many years a resident at Constantinople, and having seized him and his companions, they cast them into a prison called the chancery, regardless of the many imprisonments and repeated banishments

- In Du Fresne's Familiæ Augustæ Byzantinæ a coin of Justin's is engraved in p. 70 , with a figure such as that described by our author: those of Tiberius, in p. $\mathrm{I}_{4}$, uniformly have the cross. 
which he had now been called upon for many years to endure. The season, moreover, added to the severity of their sufferings: for it was Christmas, and the prison was in such bad repair that the water ran down at the corners, and after rain the drip continued for two or three days, owing to the ruinous state of the roof, so that they were, in a manner, cast into a pool, and were obliged constantly to stand up and exert themselves in baling out the water. They were glad, moreover, to throw themselves upon mattresses used to bury the dead in, because they had no other place where to lay their heads. And to all this annoyance was added, that twice every day they were attacked by bishops and metropolitans and church lawyers sent to examine them. And when the grace of God which was with them, so sustained them that they did not give way, but fearlessly contended with great freedom of speech for the truth of the orthodox faith, their dyophysite persecutors, being beaten in argument, made use of insults and threats. And this continued for eighteen days, during every one of which there were meetings of syncelli and œconomi ${ }^{\mathrm{P}}$ and other clergy, and also of lay-

p At first the church depended solely on voluntary offerings, but in the fourth century ample endowments were given by wealthy laymen; and that the time of the bishops might not be occupied with temporal matters, treasurers, called œconomi, were appointed to manage the episcopal revenues; and subsequently those of monasteries; and these treasurers naturally became men of importance. 
men, to debate with them: and while Tiberius was scattering his largesses, they lay in prison. But when nothing could prevail upon John to yield to the patriarch's will even in words, sentence was finally given that he must quit the city: whereupon he was led out of the prison with his friends, rejoicing and praising God that they had been counted worthy again to suffer for His name's sake. For Eutychius had even sent and torn away from John an easy chair on which he used to sit because of the gout in his feet. And much besides he had to suffer, but has contented himself with recording a few facts out of many.

III. г6. The day after John had been let out of prison, a troop of persecutors,-or rather perhaps they might fittingly be called a band of robbers,-assembled and attacked the church of the orthodox situated in the extensive palace called the Marianum. It was Sunday, and the congregation were engaged in worship when they entered and arrested many of them : and going, like heathens, to the altar, they lifted it up, and overturned it, and broke it, and poured out upon the ground the consecrated wine, and scattered the eucharistic bread; and after destroying and spreading ruin throughout the church, and tearing down the pictures of the blessed Severus and Theodosius, they dragged off the clergy who were ministering there and many of the laity, and carrying them, as in mockery, head foremost, took them to the common prison, and confined them in the same 
ward-house in which John himself had lately been shut up. The majority of them, however, after pillaging them of every thing that fell into their hands, they let go; and the rest, a few days after, Eutychius caused to be brought into his presence, and subjected to a long examination, at the close of which, in the evening, he set them free. But when at length the merciful king heard of these things, he rebuked the patriarch, and somewhat restrained his impetuosity.

As regards Eutychius himself, when, after III. i7. John's death, he was invited to return to his see, people spread abroad the report that he was a righteous man, and had the power of working miracles, and seeing visions: and he was even weak enough to imagine this of himself. When, however, upon his restoration, no legal inquiry was made into his deposition by his predecessor, but he mounted his throne in the cathedral church without even the act of excommunication issued against him being annulled, many withdrew themselves from his communion as being a man excommunicate and formally deposed by the late patriarch; and also because having retaliated by excommunicating his rival, he now accepted his ordination and every thing he had done as valid, without any inquiry or examination being held. And besides this, there was also a second cause of offence to the church, in that when shortly afterwards he had heard of some persons who were infected by the erroneous doctrine of John Grammaticus of Alexandria, 
who, as we have mentioned in the preceding book, held that the present bodies of men do not arise at the resurrection, but others in their stead; Eutychius was perverted by it, and greedily swallowed it, and undertook the defence of those who do away with the resurrection, and argued that the case is so, that this body does not rise, but another is formed, and takes its place. Upon this, several of his suffragans and leading clergy and others reasoned with him, but only confirmed him in his belief, and he even composed a treatise in its defence, and had several copies of it made, which he distributed among the ladies of the court, that they might read it, and be taught his views. And many other similar absurdities were committed by him in word and deed, so that people began to regard him as a simpleton, who was out of his mind. But really, as was only too manifest subsequently, an evil spirit vexed and troubled him, so that on two several occasions, as he was standing at the altar in the great church, it tore him in the presence of the whole congregation, and they hastily put him into a litter, and carried him out. And once again in the church of the blessed mother of God in Chalcoprateia 9 ; and often, as men said, in his palace it threw

q This district of the city was so called because inhabited chiefly by Jews, who followed the trade of braziers. The church of the Virgin situated in it was rebuilt by Justin and Sophia, after having been destroyed by an earthquake, and was famous 
him on the ground. His friends, who were anxious to throw a veil over it, said, that from long fasting and watching, the humour was stirred up, and got into his head, and there congealed, and produced vertigo, and made him fall; and that he had not a devil. But many, in answer to this, said, 'Does humour tear a person, and convulse him, and make him foam, and roll upon the ground?' And besides, all his acts soon made it plain to every body that his mind was troubled and darkened by an evil spirit; for his words often were quite beside the purpose, and he would break out into unseemly fits of laughter, and other similar follies. He also wrote a book entirely from beginning to end in defence of the doctrine of the two natures remaining after the union, and in it he found fault with all the fathers, who had not blasphemously taught like himself a quaternity in the place of the holy Trinity. And this book also he circulated among private houses, that they might learn it; but all who read it only laughed and derided him, regarding him as a simpleton, who was not right in his mind : and, in fact, the common rumour throughout the city was, "Verily, this man, whom they described as working signs and miracles, is quite bereft of common sense.'

The real cause of these absurdities was Euty- III. 18.

both for an ancient image of our Lord, which Leo the Iconoclast vainly endeavoured to destroy, and also for possessing a girdle, once worn by the Virgin. Cf. Du Fresne, Const. Christ. lib. iv. p. 85 . 
chius's pride: for upon his restoration to the throne of the church of the royal city, on finding himself firmly established there, and the object at first of general praise, and further received with the utmost honour by the merciful king Tiberius, he was immediately so puffed up with arrogance and vanity, as not to know his position, and say things superfluous and unmeaning, which led to his being talked about and ridiculed as wanting in good sense. And it was this which led to his publishing the large book referred to upon the two natures, by which he only called attention to his infatuation; and what was worse, he began sending copies to the houses of the chief men, and required ladies of senatorial rank, and their husbands, especially if previously opposed to this doctrine, to read his arguments, and assent to them, and own that for certain the two natures did remain distinct after the union: and any one who did not own this was a heretic, he said, and follower of Eutyches. But the only effect was, that even his own side ridiculed him, and sent him back his books.

III. 19. Furthermore, this proud and haughty Eutychius shewed his zeal against the phrase, 'That wast crucified for us,' introduced into the Trishagion, and threatened and disputed with every one who ventured to use it. Now there were at Constantinople certain famous and princely convents of ladies who had fled from Antioch at the commencement of the persecution, and from that time had dwelt in various parts of the capital, 
and who, according to the custom and tradition of the East, used to say in their services, "Thou that wast crucified for us, have mercy upon us.' And on this account Eutychius paid them a visit in person, attended by his clergy, and began explaining to them, and teaching them the impropriety of the expression: and threatened them with punishment unless they discontinued it. And whereas in the days of the victorious Justin, in the persecution which he authorized against both them and every body else, some of these nunneries had conformed to the council of Chalcedon, and some had resisted to the last, they now unanimously all assembled, and determined firmly to resist this innovation, saying, 'We have gone far' enough, in having at your compulsion changed and corrupted our faith: but to deny our God, Who was crucified and suffered and died,for us, is a thing we will never assent to, spite of sword and cross and fire.' And as they all with one voice warmly and decidedly exclaimed and protested to this effect, the clergy, seeing the firmness and determined zeal which made them utter these things to the patriarch's face, said to him, 'Come, my lord, we must go: it is time for service:' and so he arose and departed, without at all effecting his purpose. And finally, he wrote a long treatise, full of instruction and flattery and threats, and sent it to them: but they paid no heed to it, saying, "We are but women, and know nothing about controversy : but from the tradition of the Oriental Fathers we will never depart as long as 
we live.' 'The story was soon told about the city, and thence reached the palace, and the ears of Tiberius; and as the whole attempt met with his and general disapproval, the zeal of Eutychius cooled down, and he kept quiet.

III. 20. In the fourth year after the restoration of Eutychius to his see, he set his face against the orthodox in bitter malice, sending his emissaries to seize and plunder and imprison, overturning everywhere their altars, and tearing down their pictures, and plundering by open robbery everything they could lay hands on, such as altar furniture, and vestments, and carpets, and books and cushions, and, in short, everything there was wherever they went. They seized moreover upon men's persons, with the view of extracting money: and throwing even priests and bishops into prison, they kept them there in bitter misery as long as they liked, until they had wrung every thing from them. And those who had nothing were compelled to borrow, and give it; and though thus they were set free, and came out of prison, it was in poverty, as they had saved nothing whatsoever from their former pillaging : but those who had no means of obtaining money were banished, or sent to various monasteries for imprisonment, and were treated there with much severity. And the excellent Eutychius used to go to the merciful Tiberius, and accuse the whole body of the believers, wickedly and unrestrained by the fear of God. And while all the heretics, such as Arians, and Macedonians, and Samosate- 
nians, to whom he himself belonged, and Manichæans, and Marcionites, and the followers of Manes, dwell every where in peace, with no one to trouble them, the true believers alone were persecuted and spoiled, and sent into exile, to distant cities and various islands far away in the sea, and delivered over to every kind of misery in heavy bonds and close imprisonments, and hunger and thirst, and trials of every kind; so that if the grace of God had not visited them, and strengthened them, "no flesh of them Mat.xxiv. could have lived," according to what Scripture ${ }^{22 .}$ says of the distress which is foretold as about to be at the end.

In permitting this persecution, Tiberius was III. 2 r. but partially to be blamed. For he was occupied entirely with the dangerous wars which surrounded him on every side; and when the bishop Eutychius daily visited him, and incited him against the 'distinguishers,' he at length answered, "Trouble me about such things no more: I have as much as I can do with the wars I am engaged in: you must act in church matters according to what you think right at your own risk. Look to it yourself. I am free from guilt in this matter.' Thus left to himself, the patriarch, without fear of God or the king, widened and aggravated a persecution the sole object of which was plunder, and not anything connected with the faith. And to extend it to every land, and induce men to persecute after his example, he even deigned to write himself to all the pro- 
vinces and chief towns, urging them everywhere to commence a sharp persecution against the distinguishers as he had himself done: and as they were themselves ready enough to do it for the sake of the plunder and spoil of men's property, and the open robbery permitted on pretence of the faith, they set a persecution on foot, in company with his creatures and others, in every province and in all directions, while the victorious king was so occupied with the trying wars which surrounded him, that he could afford neither the time nor attention necessary for examination and inquiry into these things.

III. 22. Be this then known to all men, who in time to come shall fall in with these narratives, that in thus writing we adhere strictly to the exact truth; and although we profess ourselves the opponents of the excellent patriarch Eutychius, yet even so, we have not departed from the truth even in one point out of a hundred, nor have we recorded these things through any desire to bring reproach and scorn upon him. And equally so with respect to his serene majesty, we have neither spoken nor written any thing with the view of flattering him, but have endeavoured in all things to be the advocates of truth. And yet when the king Tiberius was but a youth, and his cheeks undarkened by a beard, we both of us, together with the rest of the court, were constantly in one another's company, in attendance upon his late majesty Justin ; and owing to this, 1 have long had the fullest knowledge of his 
manner of life and conduct. And now that he has been thought worthy of being elevated to his present royal dignity, we assure all those who are not eyewitnesses of it, that he continues to practise the same frankness and humility as of old, without being changed or filled with pride, as so young a man might be by the possession of royal power. Nor will he permit any one to be put to death, or plundered of his property, as was the practice of his predecessor, who stained himself and his hands with innocent blood : but up to this present time, which is the third year A.D. 581 . of his reign, besides the four during which he was Cæsar, he conducts himself with nobleness and humility, although many find fault with him as being too quiet and humble, and inspiring no fear; but in spite of their representations, he still continues his gentleness of demeanour up to this present time.

While king Tiberius, or, as he is also called, III. ${ }^{2}$. Constantine, was Cæasar only, and Justin occupied the palace ${ }^{r}$, scanty apartments were assigned for his use in one of the wings : and even after Justin's death, as Sophia gave no signs of changing her residence, and he was unwilling to dispossess her, and she would not permit him to reside with her, he was in great difficulties, as the space al-

r The name here given to the palace is the Authenticum, as aủ $\theta^{\prime} \nu \tau \eta$ s had now become one of the recognised titles of the Emperor. 
lotted him had always been of the narrowest description, and now that he was sole master, and had been joined by his wife and two daughters, was altogether inadequate to his wants. As he would not therefore oppose or annoy queen Sophia, by taking up his residence in the palace itself, he was compelled to remodel the whole of the northern side, and erect large and spacious buildings; for which purpose he was not only obliged to take down the extensive edifices already existing there, but also to sacrifice a beautiful garden, which had existed in the interior of the palace, and been a great pleasure to former kings. Upon its site magnificent and splendid buildings were erected, including a noble bath, and spacious stabling for his horses, and other necessary offices.

III. 24. Justin had also busied himself in building, even when engaged in persecution, and the troubling of the church, and in plunder and pillage; and when too the dread punishment was sent down upon him: but in this also there had been evident signs of the wrath of Heaven resting upon him. For having formed the idea of erecting a palace upon the site of his former dwelling in the north-western suburb of the city, he razed a great number of houses there to the ground, and built a hippodrome, and laid out extensive gardens and pleasure-grounds, which he planted with trees of all kinds: and gave orders also for the erection of two magnificent statues of brass in honour of 
himself and Sophias. But scarcely had they been set up, before a violent storm of wind occurred, which overturned them, and they were found deeply imbedded head foremost in the ground. And this was regarded by men as a sign of wrath and impending ruin. But Justin, nothing discouraged, next determined upon building a pharos, that is, a tall and lofty pillar, whence to enjoy the view : and this he commenced in the eastern part of the city on the seashore, in what is called the Zeuxippust. Within it a vaulted stair was constructed, so broad and strong that the workmen could mount up it with loads of massive hewn stone; which were cramped together with bars of iron, and strongly cemented with lead. And when it had reached a great height, and was all but completed, some of the city wits

s An account of these statues is extant also in Cedrenus, who describes them as set up near the harbour subsequently known as the Palace Haven, but then called by the name of Sophia. Theodosius Melitenus also, p. 94, describes their erection upon the Julian port, which Justin, he says, cleaned out, and called by the name of the Empress.

t The Zeuxippus was a splendid bath, built by the Emperor Severus, and surrounded by extensive pleasure-grounds, in which were collected the chief treasures of art in Constantinople. Its beauty is the theme of many Byzantine writers, and whole books of epigrams have been written upon the master works of statuary deposited there; one of which was a statue of the Sun by Zeuxippus himself, whence the bath took its name: but its chief glory was a statue of Homer, sitting, full of thought, his hair and beard rough and neglected, and his hands folded on his breast. 
wrote a doggrel inscription, and fixed it up on a tablet there, as follows :

Build, build aloft thy pillar, And raise it vast and high ;

Then mount and stand upon it,

Soaring proudly in the sky:

Eastward, south, and north, and westward,

Wherever thou shalt gaze,

Nought thou'lt see but desolations,

The work of thy own days.

Before its completion, however, Justin died, and it is said that the question who should finish it led to a quarrel between Tiberius and Sophia : for she bade him undertake it; but he said, 'I shall do nothing of the sort; for it is your duty to finish it.' And she, supposing that at all events he would complete it, if his own statue were placed upon it, said, 'If you will not finish it in honour of him who began it, do so for yourself :' at which he was angry, and vowed that his statue should stand neither upon it nor any where else. Subsequently, when he saw that the huge blocks of stone employed in it would be useful for his new buildings in the palace, he had it entirely taken down, and the stones removed thither, and to the church he was building close by, dedicated to the 'forty martyrs :' and it supplied him with materials for a long time. This folly was said to have cost Justin many talents of gold. 
The merciful Tiberius during the whole time III. 25 . he was Cæsar in Justin's lifetime, because of the king himself having fallen a prey to various maladies, was entirely occupied with the wars which surrounded him on all sides: for, besides the struggle with the Persians, he was constantly threatened in every direction by those other barbarian tribes which had risen up against the powerful empire of the Romans: and after the death of Justin, they pressed upon him with still greater violence, especially the accursed tribes of the Slavonians, and those who, from their long hair, are called Avars. For after he became sole ruler, they gave him neither rest nor breathingtime, but constantly wars and rumours of war multiplied around him : so that many, both of the chiefs and the commonalty, used to express their sorrow for him, and say, "Verily the kingdom has fallen to his lot in a time of trial and in evil days; for day and night he is anxious, and full of care how best he can gather troops from every quarter, and send them to maintain these incessant wars.'

It was this necessity which compelled Tiberius III. 26 . to enlist under his banners a barbarian people from the west, called Goths, and who were followers of the doctrine of the wicked Arius. And on their departure for Persia, leaving their wives and children at Constantinople, they asked the king to set apart and assign for their use a church, in which during their absence their families who remained behind might assemble for 
worship. And the king, anxious to content them, and considering that they were labouring to the best of their ability in defence of the Roman realm, and fighting with its enemies, said, 'We will see to it, and talk the matter over with the patriarch.' And from this promise and answer, which he gave them to satisfy them for the moment, without granting at once their request, it was supposed by everybody, and said, that the king was an Arian, and held the same doctrine as those who had made the request, only that he concealed his opinion. When then, according to custom, he went to the high church, the crowds shouted, 'Out with the bones of the Arians: dig from their graves the bones of the Arians.' And when Tiberius heard these cries, he knew that they were directed against himself, and was much disturbed; and on his return to the palace, he sent and arrested many of them, and said to them, "What see in me like an Arian, that ye have followed me with cries, and have insulted me in the church?' And when they had apologized, being in great fear of the consequences, with the view of clearing himself from the supposition, he gave orders that the Arians should be persecuted. And having thus obtained the opportunity, the ruffians in the church, on pretence of the edict, rushed like so many wolves, not only upon those to whom the commandment applied, such as the followers of Manes, the Macedonians, the Samosatenians, and others, but upon those to whom it did not apply, and confounded the or- 
thodox with them, and fell upon all alike, and plundered without distinction, until their doings reached the king's ears, and he rebuked them, and sharply threatened them, unless they immediately discontinued such conduct.

In the second year of Tiberius' reign, A. D. 579, the news reached the capital that the wicked heathens at Baalbec, otherwise called Heliopolis, who were professed worshippers of Satan, were plotting whenever they could find an opportunity to destroy and wipe out the very remembrance of the Christians in that town, who were few and poor, while they all were in the constant enjoyment of wealth and dignity. They indulged moreover in scoffs at Christ, and all who believed in him, and had already ventured upon many acts of open violence. Upon the news reaching Tiberius, he intrusted the matter to an officer who had already a short time before been sent to the East by Justin, upon the occasion of a revolt and disturbance created by the Jews and Samaritans in Palestine: and who on his arrival there had effectually reduced them to order, exterminating some and crucifying others, and destroying their property, and compelling them, by the severity of his measures, to submission. On receiving the king's commands, this officer, whose name was Theophilus, proceeded at once from Palestine to Heliopolis, and having arrested numerous heathens, recompensed them as their audacity deserved, humbling them and cru- 
cifying them, and slaying them with the sword. And on being put to the torture, and required to give the names of those who were guilty like themselves of heathenish error, they mentioned numerous persons in every district and city in their land, and in almost every town in the East, but especially at Antioch the Great. Of most of these he was contented with sending the names to the magistrates of the place where they resided, with orders that they should be arrested immediately, and sent to him : but Theophilus despatched one of his own attendants to secure the person of Rufinus, whom they had mentioned as holding the office of high-priest at Antioch. On the officer's arrival, however, he found that Rufinus was not there, but had lately gone on a visit to Anatolius, the governor and procurator of Edessa. Having demanded therefore the services of a magistrate to escort him, and of a bishop to conduct the examination; as soon as they were granted him, with an officer of the church court, he started for Edessa, in the hope of arresting Rufinus there.

III. 28. On their arrival they learned that he was dwelling there, and having waited for night, upon surrounding the house in order to arrest him, they found a feast of Zeus actually being celebrated by the heathens, and people assembled together with Rufinus to offer sacrifices. On becoming aware, however, that they were endeavouring to surround the house, those present took the alarm, and fled. But Rufinus knowing well that 
he had no place of refuge to which he could escape, drew his knife, and smote it into his heart, and having given himself also a wound in the abdomen, fell down dead. There was, however, a gouty old man, too feeble to flee, and an old woman, whom on entering they found still present, with the dying body of Rufinus stretched upon the ground, and surrounded by the preparations for sacrifice. Upon them therefore they laid hands, and threatened them with instant death, unless they truly declared the names of all who had taken part in these proceedings; but if they would make a full confession, they promised that no harm should happen to them. And they being in terror of death, told all their names, and among them was the governor and procurator, Anatolius. He meanwhile had contrived a subtil way of escape, which however proved of no avail : for hastily wrapping himself in his travelling coat, as if just come from a distant journey, and putting on his leathern leggings and walking shoes, he went to the bishop's house. And he on hearing that the governor was come, was in a great state of terror, and said, 'Why has the governor come hither at this unseasonable hour?' But being admitted, he said, 'I have come hither straight from my journey, that I might be satisfied about a certain text. For I have had a dispute about such and such a passage of Scripture, and am in doubt as to its right explanation: and therefore $I$ have 
paid you a visit before going to the government house, that you may explain it to me.' But this he only did in subtilty, that he might have the bishop to bear witness, that he had called upon him fresh from a journey; and in case they were to say that he had been that night in the company of those who offered the sacrifice, he trusted that this trick would set the matter right. But, I Sam. ii. as the Scripture says, "The Lord is a Lord of 3. knowledge: and artful ways shall not be established before Him ?' so this man's artifices did not stand. For just as he left the bishop's presence, those who had been sent to arrest him met him, and laid hands upon him, and said, 'Come peaceably with us, my lord governor: we are greatly in need of your highness : give orders for bailsmen to be put in for you at a talent apiece, that within ten days you appear at Antioch.' But he in answer began to explain to them, and say, 'I have but just entered the city from a journey, as the bishop will bear testimony.' But they replied, 'It is no use playing us tricks, my lord governor. This very night you have been with Rufinus and the rest of your people, and have offered sacrifice to Zeus; and the witnesses are all ready to prove it.' And when upon this he threatened them with his power, and said, 'You are putting a stop to all 'matters of state;' they replied, ' Threaten us not, my lord governor: as your highness is a living man, you will not get away from hence without 
giving us bail.' And now finding that he had no choice, nor probability of escape, he consented, and gave bail, and set out immediately with them and their other prisoners for Antioch.

On their arrival at Antioch, and the deposi- III. 2 . tions taken at Edessa concerning the heathens found there being read over, both Anatolius and his secretary, whose name was Theodore, were arrested and put to the question: and at first they had recourse to falsehood, but finally the secretary, after being tortured and severely scourged, declared his willingness to confess every thing: and, as was said, they deposed that both Gregory, the patriarch of Antioch, and Eulogius, who was subsequently patriarch of Alexandria, had been present with them at the sacrifice of a boy, held by night at Daphne: and scarcely, said they, had they completed the sacrifice, before the whole city suddenly trembled and shook with earthquake. No sooner was this confession heard, than the whole population was filled with horror and amazement, and various cries were raised, and the cathedral closed, while Gregory could not venture to leave his palace, nor could the liturgy be celebrated, nor the consecration of the holy chrism, as is usual on Thursday in Passion week. The full account, however, of what took place, and the cries raised, we must be excused from recording; but, as was said by all men, the depositions were sent to the king, and the affair became the subject of general conversation: but finally, it was thought, 
that for the honour of Christianity, and that the priesthood might not be exposed to scorn and blasphemy, the matter must be hushed up.

As for Anatolius, having set up in his house a picture of our Lord, in the hope of making people erroneously suppose that he was a Christian, he invited a number of persons to come and see it. But as he was shewing it, the picture turned hindside foremost with its face to the wall, so that astonishment fell upon all who witnessed it. Anatolius, however, turned it back again, and put it right; but suddenly, a second time, it turned round; and again a third time. And upon this they examined it closely, and found skilfully introduced into the back a likeness of Apollo, so carefully done as not to be visible without looking closely at it. Horrified at the sight, the archers threw him on the ground, and kicked him, and dragged him by the hair to the Pratorium, where they declared all that had happened: and, as was said, finding escape impossible, he also made a full deposition of every thing.

His notary, Theodore, who had made the deposition respecting the bishops, and the rest, being kept in prison, subsequently, as we shall shew hereafter, died there, and it was the general belief that really he was murdered, in order that his deposition might be got out of the way: but to the truth of this we will not bear testimony, nor have we space for much besides which happened. 
When, however, the news arrived at the capi- III. 3 . tal, accompanied by the depositions of what had taken place at Antioch, the whole city, together with the merciful king and the senate, were moved, and struck with consternation and astonishment, and nothing else was talked of in all parts of the city. And on the arrival of the prisoners, a court was appointed, consisting of magistrates and jurists, to try them, and examine into the truth of the matter, upon oath that they would shew no partiality nor respect of persons. Accordingly they held their sittings in the royal palace of Placidia, but their proceedings were secret, and although a few facts transpired, it was in spite of their own efforts to conceal them. And after some time, men generally were convinced that bribery was permitted, and prevailed over the truth: and while there were known to be in the city many followers of heathenism, the people considered that the court acquitted whom they chose, such, that is, as gave money, and whom they chose they unjustly condemned; and that the quest for the heathen was carelessly and corruptly carried on : and the more so as the king was indifferent to it, and had gone out to one of his country palaces, and what was done was kept secret from all eyes.

There was, therefore, much murmuring and III. 3 r. complaint because the matter was, as they considered, put out of the way and dropped by the influence of gold, and was coming to an end, and nullified, and even such heathens as were ar- 
rested set free; and the dissatisfaction proceeded so far, that at length crowds began suddenly to gather in the heart of the city, and give utterance to their indignation in cries, such as, 'Out with the bones of the dicasts!' 'Out with the bones of the heathens!' 'The faith of the Christians for ever!' 'Out with the bones of the dicasts!' meaning by them the judges appointed to try the heathens, and who, they considered, had taken bribes, and so ruined the whole matter. And no sooner were these cries heard than people flocked to them from all parts of the city, so that the number of the rioters rapidly increased to more than a hugdred thousand men, all inflamed with zeal for Christianity. In alarm at so vast a mob, the whole city was troubled, the shops were shut, the silversmiths' workshops closed, and Jews, Samaritans, and heretics of all kinds rushed from every quarter, and mingled themselves in the crowd, ready both to set the city on fire, and steal whatever came to hand. Meanwhile the Christians were hurrying under great excitement to the cathedral in the hope of seizing the bishop, uttering by the way many scandalous reproaches at his conduct, such as are not fit for us to record; accusing him of taking side with the heathens, and supposing, because of the rumours of heathenism current against the bishops of Antioch and Alexandria, that he had used his utmost exertions to screen them from trial, and so brought the matter to an end: and therefore they threatened him with death. But 
on reaching his palace, they found it shut on every side, and some of the mob, therefore, were ready to burn it: but there stood a church within the precincts, which stayed their rage, though the Jews and heretics, as they afterwards confessed before the prefect of the city, were ready to burn the church as well. An official of the patriarch's court now came out to address them, but they threw him down, and gave him a bitter time. And next they all ran to the hall of Placidia where the trials were carried on: uttering reproaches against the judges and patricians and magistrates and recorders and jurists, who formed the court, and threatening them with destruction. Upon arriving there, they burst open the doors and windows, and broke to pieces the benches and the cells, and forced an entrance into the great hall, and made search every where for heathens. One of the cells into which they broke belonged to the treasury, and was full of talents of gold; but on seeing them they immediately turned away: and the sentinel, wishing to appease their violence, and supposing that they would immediately begin to plunder, said, 'Sirs, make no tumult; if you wish for gold, see, here is plenty.' But, as with one mouth, the whole multitude called out, 'We are no thieves: we are Christians, and assembled in Christ's cause, to avenge the wrongs of Christianity upon the heathen. Keep your gold for yourself; we touch it not.' Rushing on, they destroyed every thing in their way, even some pictures which they 
found, and pulled down all they could, and broke it, and finally they found two heathens in. prison, a man and a woman, with whom they hurried off to the shore of the sea, where they seized a boat, and having laid hands on the public executioner, commanded him to set it on fire. But when he refused, being afraid of the prefect of the city, they put them on board, and threw fire in, and flung the executioner in with them, but he managed to leap overboard into the sea, and though much burnt, escaped with his life: but the other two were consumed and sunk in the sea". And next the mob, whose numbers were now incredible, ran to the prisons, and broke open the doors, and set the prisoners free, calling out, 'Ye let heathens go: why keep ye Christians in prison?' And thence they ran to the prator's government-house, and broke open the doors, and having entered the chambers and record offices, in which all processes against Christians are deposited, they abstracted the papers, and cut them up and threw them about, and set those who were imprisoned there free. Their next object of attack was the dwelling of the prefect of the city, whither they proceeded with tumultuous and violent cries of 'Out with the heathens' bones :'

u This method of executing criminals was not an uncommon one at Constantinople. Among other instances, we read in Chron.

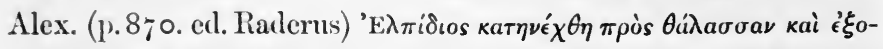

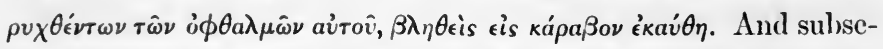
quently the murderer of Eustochius was thus put to death, iii. 35 . 
and he, though it was universally said that he was a heathen himself, joined heartily in their shouts, saying, 'Out with the heathens' bones: Christianity for ever: your zeal is beautiful: and see! I join you in your cries: and ye know that I was not one of the judges of the heathen; they would not trust me, and no heathen has been judged in my court: make, therefore, no tumult.' And with these words he restrained their impetuosity, so that they did not lay hands upon him as they had intended, and burn down his court. They cried out, however, that he must accompany them immediately to Tiberius' palace in the suburb; and he was far too terrified to refuse : and calling hastily for a boat, he started in the utmost confusion, without even waiting to put on the insignia of his office, being solely intent upon making his escape from the violence of so countless a mob. He started, therefore, in haste to the king; and while informing him of what was going on, suddenly more than twenty thousand rioters appeared, who had determined to come in person, and arrived at the very time when he was speaking, uttering various cries, and moreover asking why the inquisition after the heathen was perverted, and hushed up; and why bribery was permitted to overbear the truth. And after uttering these cries against the heathens, they began to shout and revile the Arians, having a different object in view; and the whole palace was thereby thrown into confusion, and things were said un- 
fit to be recorded in writing. Finally, the king sent them a message as follows: "Make no tumult, but return to the city, and we will immediately return there ourselves, and do what you wish ; nor will we neglect the matter.' And so the mob was quieted, and the fierceness of their rage appeased, and they returned to the city, and the riot ceased, as they waited for the arrival of the king, and the fulfilment of his promise.

III. $3^{2}$. Upon their departure, the king gave orders to collect a considerable force of armed men, that in case there was any disturbance, he might take military measures for its suppression, and with them entered the city. His first act was to give an equestrian entertainment in the Hippodrome; but when the people assembled, they began to utter cries of various kinds, until he sent and bade them be quiet and peaceable: 'for you know,' he said, 'that every man shall be recompensed according to his deeds.' And upon this all tumult and confusion ceased. Immediately upon his arrival he had dismissed the prefect Sebastian from his office, and appointed in his stead one Julian ${ }^{x}$, to whom he now gave orders to arrest such as were known to have taken part in the tumult, and put them to the torture, and find out who the rest were. On commencing his interrogatories, Julian found out that many of them were

$x \Lambda$ word occurs in the original which $I$ am unable to translate, namely, נosese. It reads literally, ' and another who was

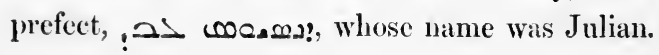


Jews, and some Samaritans, and some Manichees, and the like; and being a sensible man, he had these arrested, lest he should stir up a war against himself, by rousing the zeal of the Christians: and examining them with the scourge, he asked them, saying, "Though the Christians are carried away with zeal for the welfare of Christianity, what right have you Jews, who are a set of murderers and misbelieving heretics, to take part in the riot, and mix yourselves up with them?' And they all confessed, that seeing a great crowd, they had entered among them, in the hope that something might come to them in the way of plunder: and as they further confessed, they were ready to burn the churches, imagining that the Christians would be arrested, and put to the torture for it, while they would pass unrecognised. They acknowledged also other crimes under the scourge; and some therefore he condemned to be crucified, and some to be put to death, and some he sent into banishment. And in this way no Christian could complain, or say that anybody was treated unjustly. But next he arrested some of the Christians, whom, however, he treated with the greatest clemency : and when they took them round the city to inspire others with fear, lest men should notice that there were no marks of the scourge on their sides, he gave orders for them to be rubbed with vermilion, that their loins might look red as if marked with the lash: and this especially was done in the case of young lads, of whom many 
were found to have taken part in the uproar, and some of whom even laughed when riding in the cars, and taken in procession round the city. At length there was a man arrested, and brought before the prefect, who said to him, "Who and what are you?' He answered, 'A Christian and a storekeeper.' 'If you are a storekeeper,' said the prefect, 'what business had you to take part in the riot? why did you not remain in your shop, and keep quiet? We give orders therefore for you to be scourged.' But as they were carrying him away to scourge him, he cried out, 'By the head and life of the king, if I am to be scourged for Christ's sake, do not inflict upon me only lashes and the scourge, but after this, by the life of king Tiberius, off with my head!' And when the prefect heard this, he was agitated, and said, "This man wishes for martyrdom at my hands. Am I then such a Trajan? Loose him, and let him go.' And so he let him depart without receiving a single blow. And proceeding to the king, he persuaded him to grant an indulgence or amnesty to the Christians, and command that no more should be arrested for their past riotous proceedings. And upon this the merciful king granted a pardon, and all arrests ceased.

III. 33. After all these things, his serene majesty Tiberius, with a view of shewing that he neither had nor would neglect any thing that was useful for the service of God, gave orders to all magistrates and senators to assemble together, in com- 
pany with all men of patrician rank, and the subconsuls, and those who bear the title of 'illustrious,' and the subprefects of the city, and all members of the senate. The place appointed for their meeting was the prefect's court, and all the depositions relating to the heathen were to be read before them, both of cases in the east and in the west; and whosoever was not present he gave orders that his girdle should be cut, and he should lose his office. In obedience to so strict a commandment they all met, and sat the whole day from morning till night fasting, and anxious; and upon the depositions being read, their first sentence was to condemn to death him of whom we have spoken before, Anatolius, the governor and proprefect of Edessa. And accordingly he was first tortured, and then cast to the wild beasts, and after being cruelly lacerated by them, he was torn from their claws, and fixed to a cross. But the other, named Theodore, who had been his yokefellow, and with him had served devils, according to all the works of heathenism, after suffering long and cruel tortures, and confessing much, was reserved for fresh tortures, and a fuller examination. For this purpose he was sent back to the prison attached to the prætor's court, and there during the night he died; or rather, as many thought, he killed himself, because the sentence of death was certain to be pronounced against him. And as he had offered sacrifice to devils after being baptized, sentence was still given against him, 
though dead, that his body should be burned. But as the natural feelings of humanity revolted at this, and many objected, the sentence was withdrawn, and he was ordered to be buried with the burial of an ass, and accordingly was dragged out of the city, and cast into a ditch. His execution was in addition to those two, a man and a woman, whom the mob burned; but that man was the son of this Theodore: and thus then they perished, and many more besides, already lying in prison, and whom they next proceeded to examine by torture: and others there were in Syria and Asia, and elsewhere, after whom they sent emissaries, with orders to arrest them, and bring them to the capital.

III. 34. Upon this, fresh names began to pour in, and every day new arrests were made, and more and more involved in danger, until the prisons were all full : and even many of the clergy officiating in the churches were informed against, and convicted of many heathenish crimes, and the sentence pronounced upon them was, that they should be cast to the wild beasts, and their bodies burnt with fire. And so they received here the punishment which they deserved; and hereafter the dread Judge of righteousness alone knoweth what their sentence will be. And of the common people so many were named and arrested, that the judges appointed to examine them were unequal to the task, and finally their sittings were no longer held in the court of the 
prefect of the city, who himself had the reputation of entertaining heathen views, but were removed to the prætor's court, and subsequently to the public hall, and there the judges sat and gave sentence, until the death of king Tiberius. And when Maurice was established in his stead, he was conspicuous for the same zeal, and gave orders that all should be sought out and tried, who professed to be Christians, but really were guilty of idolatry. And so every day they were tried, and received the just reward of their deeds, both here and hereafter.

The case of Gregory of Antioch was long de- V. i7. ferred; for though the people of his city were all excited against him, and filled the streets with shouts of 'To the fire with this man: let the city have a Christian patriarch;' and the like; yet because many great and notable men were involved in the affair, it was hushed up, and put aside, and he remained in his see a stumblingblock to all the people. But after a time he made up his mind to present himself before the king, and prepared a great quantity of gold and silver, and numerous costly dresses of every kind, and such other matters as are useful for presents and gifts of honour, for the leading men in the senate: and in these things alone, it is said, his journey cost him many talents. And when he arrived at the capital, he glutted the whole senate with his presents, and every man and woman of rank; and all the churchmen, who were angry at him because of the rumour of his 
being a heathen, he quieted and appeased by gifts: as also all the relatives of the patriarch $y$, who, on hearing of his arrival, had refused to hold communion with him; and as he was not open to bribes himself, those who were about him were prevailed upon to intercede, and persuade him, until finally he received him, as also did the king, Maurice, and all the senate, and treated him with much respect, and were on his side. And when men generally expected that the process against him would be entered into, and that he would not return to his throne, he was received at court, and having effected all that he desired, was sent away with great honour. And with the view of appeasing and quieting his people, he asked the king's permission to build them a hippodrome; and not only obtained it, but also the necessary supplies wherewith to erect this church of Satan, in which he himself was ready to be minister and perform all his pleasure, so that, as was said, he even took with him from the capital a troop of pantomimists. And this to many was a cause of laughter and ridicule and mockery, but to others of grief and sadness: for they said, 'Lo! to this man the word of our Luke xiv. Lord belongs, which says, 'If the salt have lost its 34. savour, wherewith shall it be salted?' For having been appointed head of the church of Christ, now, after all the troubles we have passed through, he has publicly shewn himself as the

y The patriarch at this time was John the Faster. 
builder and establisher at Antioch of a church of Satan, in the erection of which he has constantly interested himself, and been present, and untiring in his exertions.' For so they said, in contempt and derision of his doings.

This narrative relating to the heathen, and the establishment of the inquisition, by which the last traces of idol worship were violently suppressed, leads our historian to mention one or two facts, more or less directly connected with them. Of these the

First is the tragical fate of Eustochius, who III. 35 . had originally been bishop of Jerusalem; but having distinguished himself by his eager zeal against the heathen, whom he detected in spite of their efforts at concealment, they framed against him charges of their own invention and false accusations; and on his arrival at the capital, being tried before wicked judges, who were themselves heathens in disguise, he was iniquitously deprived of his bishopric. And on being deposed, he did not stoop to wander to and fro to canvass for his restoration, but went at once and obtained a cell in the holy house of Mar Sergius ${ }^{z}$, situated near the palace of Hormisdas, and there remained during a period of

z The emperor Justinian was saved in his youth from destruction by the appearance of the two saints Sergius and Bacchus to his predecessor Anastasius, who, in obedience to his holy monitors, spared the youth's life. He, therefore, afterwards erected 
eighteen years, during which he was regarded by their majesties, and the chamberlains, and the whole senate, both men and women, as a righteous man; and constantly they paid him visits of respect, as being an old man of venerable aspect, and lucid in his conversation and doctrine, and well practised in holy books. It happened, however, in the third year of the sole reign of the victorious king Tiberius, that Satan by night entered the heart of one of his servants, and he took up a silver candlestick that was burning before him, and raised it and struck him, and wounded him on the head. And on his exclaiming, 'Woe,' and saying, 'Why doest thou so, my brother?' he returned and struck him again on the stomach with a spit, and so lacerated him that he died immediately. The lamentations raised by his other servants alarmed the sentinels who were on guard below, and caused them to hurry up to the cell, where they endeavoured to arrest the murderer, but he drew his knife, and stabbed one of them, whereupon another drew his sword, and struck him on the shoulder, and brought him down, and they were then able to overpower him. And immediately there was a general commotion, and men in terror ran together from all quarters, to see this sad and alarming sight: and the news even

numerous churches in their honour, and as he long resided in the palace of Hormisdas, and greatly increased its buildings, one of the largest of these edifices was erected within its precincts. 
reached the king, who was in the suburban palace situated in the Hebdomum ${ }^{\mathrm{a}}$; and at once, without delay, he ordered his retinue to accompany him, and came to the city; and when he saw that he was dead, he lamented and wept like a woman for the husband of her youth, as also did the bystanders at a sight so full of horror. And the king commanded the murderer to be given over to the prefect of the city, that he might die by an ignominious and painful death; and then immediately withdrew. The servant, therefore, was cast to the wild beasts, and after being lacerated and torn, his hands were cut off and then his feet: and his trunk, with the hands and feet, were then put into a boat, which was set on fire and floated out to sea till it sunk. And so he received the requital of his deeds, and that which is written was fulfilled in him, "Woe to the wicked, the evil one: for Is. iii. rr. that which his hands have done shall be requited him.'

The second subject mentioned in connection III. ${ }_{3} 6$. with the heathen is John the Superintendant's mission to them in Asia, and especially the building of the great monastery in the moun-

a The Hebdomum, also called Campus, was the open plain to the west of the city, and held, in the estimation of the people, the same place which the Campus Martius held at Rome. Heraclius surrounded it with a wall to protect it from the Avars, and made it the fourteenth region of the city. Various unsatisfactory reasons for its name are given in Du Fresne, Const. Christ. 173. 
tains near Tralles, which was both the commencement and the crowning proof of his success. He was appointed teacher of the heathen in Justinian's time in the four provinces of Asia ${ }^{b}$, Caria, Phrygia, and Lydia; and began his labours in the mountains which overhang Tralles, in the territory of which city alone he converted many thousands from the error of idol worship, and built for their use twenty-four churches, and four monasteries, all of which were entirely new. Of these the principal was erected upon the site of a famous idol temple built high up among the mountains, at a village called Derira, and as he had often been told by the older inhabitants, in the days of its prosperity no less than fifteen hundred temples, situated in the neighbouring provinces, were subject to its authority, and every year, at a vast assembly held there, the regulations were fixed for the ensuing twelvemonth, and the order of the ministrations settled for the use of both priests and people. John, therefore, being directed by a divine mission, made this temple the first object of his attack, and having levelled it to its very foundations, he built this chicf monastery, to which he gave the same name as the idol temple had held, on a strong site upon a lofty mountain in the centre of the new churches : and subsequently he erected the three other monasteries, one of which was situated still higher up among the mountains,

b By Asia is signified the district immerliately round Ephesus. 
and two in the valleys below; but all alike were subject to the authority of the monastery of Derira. And this, as the chief, he built very strongly, and of great extent, from ample funds supplied him by king Justinian, who also bore the expence of the other monasteries and churches. The king, moreover, published three imperial edicts, by which the chief monastery was invested with authority over the others, and also over the new churches, with power to visit and teach them, and take oversight of them, and settle their observances. But firom the very first Satan had looked with an evil eye upon this monastery, and raised up against it many trials and strong opposition from all quarters. For the devils who used to dwell there in times past, and fatten upon the blood of the sacrifices offered them, upon which they would settle in swarms like flies upon putrid ulcers, openly showed themselves, and contended with the builders. And when it was first begun they even went so far as to lay hold upon one of the masons who was in holy orders, and lifted him up in the air, and threw him down upon a rock below, from which he was dashed to one even more precipitous still further down; while John and the other builders gazed in horror as they watched him fly along, and fall head foremost on his face, and roll down from cliff to cliff, till finally his fall was stopped by a rock in the river, which was not less than a thousand cubits below the place whence he was thrown. And as 
they watched his descent, and cried 'Kyrie eleison,' they felt sure that his brains must be beaten out, and scattered upon the rocks against which he was dashed, and that he would be torn limb from limb. They ran, therefore, with loud lamentations to gather up though it were only the fragments of his bones, and give them burial: but on reaching the spot they found him whole, and in a sitting posture, and looking at them. And when they saw him alive, they were astonished and full of joy, and gave thanks unto God, who had saved him from a bitter death by the machinations of these pestilent devils : nor had Christ permitted him to receive even a single bruise, or any other injury except the loss of some skin upon his face. And all who saw and heard it were in astonishment at the miracle which had been wrought by our Lord Jesus Christ.

III. 37. The year after the monastery of Derira was finished, which was the sixth year from its commencement, the bishop of Tralles was stirred up by envy against it, and swore, saying, 'I will make that monastery of Derira part of the elldowment of my church, and will spend there all the hot summer season.' For even before he had a quarrel against John, and now started to thwart him at the court of Justinian. And on arriving there, he told him of the monastery, and prayed him to give orders that it might be made subject to his authority and rule, and that John might not have access to it. But the king said, 
'I have not entered either your church or city without Christ's blessing, nor could I have effected what I have done unless the management and government had been intrusted to John : for you could not possibly have administered the church which you have just now unjustly claimed. What you want is to seize upon a monastery which belongs to me, and which was built with my knowledge and at my command.' And then he commanded him not to quit the capital until after John's arrival. After a time, then, John came, and the king informed him of all that had been said to him by the bishop, and of his own reply, and further gave orders that John should go in person, and himself administer the affairs of the church of Tralles and of the bishop's own hospice there, and that the bishop should have no power to do anything whatsoever without first receiving his orders from John. And other trials too there were and difficulties, which Satan raised up against this monastery, and the twenty-four new churches which John had erected in its vicinity for the service of the heathen whom he had baptized and made Christians in the mountainous districts of the city of Tralles : but God in His mercy brought to nought all the envy of the evil one, and established them unto the glory of His name, so that they continue to flourish unto this day.

Eutychius enjoyed the patriarchate after his III. $3^{8}$. restoration for a period of four years and a half; 
and while full of threats of death against the orthodox party, and menacing them with terrible oaths, and saying, 'I will not leave one of them in this city, or in its suburbs, or in any other town in my diocese;' in the midst of his raging and threatening, his end suddenly overtook him, and he descended into his grave, and on that day all his imaginations perished, and came to an end, and all his threats and denunciations ceased. His errors in doctrine were numerous, as he both explained away the resurrection of the dead, and warred against the words, 'Thou That wast crucified for us:' and much more there was which ought to be inserted in the record of him, but which we from their length must entirely omit.

III. 39. Scarcely was Eutychius dead, upon the fifth day of the month Nisan, or April, before John the deacon was seized upon, that they might raise him to the vacant see. He had been pursebearer of John of Sirmin, the predecessor of Eutychius; but after his death, had constantly dwelt in his cell in the great church as a Nazaritec, and devoted himself to fasting and vigils. Him they now seized upon, but he would not even so much as hear the bare proposal of being raised to this princely dignity. On his refusal, king Tiberius gave orders that he should be brought by main

c If we may believe Michaelis, these Nazarites were a monkish sect, who took a vow entirely to abstain from bread and wine; and supposed that they kept this row hy having the consceration service of the Eucharist performed over it, ly which means it became flesh and blood. 
force to the palace, and there kept under close guard, while both he himself and the whole senate pressed upon him the acceptance of the patriarchate, and finally, with great difficulty, prevailed over his scruples. But he protested, saying, 'I cannot alter or break my rule, and until three o'clock in the afternoon I can give no one audience.' And, in short, after many discussions, he was finally elected, and they say that he made it his rule never to admit any one until three o'clock, according to his former custom: and men wondered thereat, for, as was said, he lay the whole day upon his face and prayed, being reduced to a state of great infirmity, and as dry as a stick.

The hangers on, meanwhile, of the patriarchal court, who had been accustomed in the days of Eutychius, under pretext of the faith, to fall like so many robbers upon orthodox and heretics alike, and plunder them of their goods, began, according to their wont, to beg of him to grant them his permission, as his predecessor had done, to enter into men's houses, and plunder them, and drag them off, and shut them up in prison. But he, on hearing their request, said, 'Depart, and sit quiet: for I will not permit you to go and fall upon men, and plunder them, whereby God and His holy church are blasphemed.' And on their saying, 'Eutychius so commanded us;' he replied, 'My orders are, that there be peace and quiet in my days. But if you make Eutychius your pretext, go to him for orders; and if 
he bids you, you shall do it.' And much more is recorded of him that is admirable, but we, from want of space, can admit but little into our narrative.

II. 40. For the affairs of the empire also claim our attention, and especially what happened to Mondir, the son of Harith d, king of the Tayan Arabs, and of the accusation brought against him. For when Maurice was in the East, as commander of the forces, with the title of count, a convention was made with Mondir, king of the Arabs, that they should simultaneously invade the territory of the Persians. Accordingly they made a march of several days in company; but on arriving opposite Mesopotamia, in which country the capital of the Persian king is situated, they found the bridge destroyed, over which they had expected to pass in order to capture the city. And this led to a quarrel between them, because Maurice imagined that Mondir had given information to the Persians, upon receipt of which they had broken up the bridge. They returned, therefore, having accomplished nothing, but with feelings of mutual animosity and dislike: and both wrote

d If Caussin de Perceval is right, of which however I am doubtful, John of Ephesus confounds here two Mondirs: it was not Mondir, son of Harith, the Ghassanide ally of Rome, and a Monophysite Christian, who played Maurice false, but Mondir IV, son of Mondir III, the heathen king of Hirah, and a vassal of Persia. As the subject is however too long for a note, I must refer the reader to the Dissertation appended to this book. 
to king Tiberius, complaining of the other's conduct, and he in vain used his utmost efforts to reconcile them. When, however, soon afterwards Maurice returned to the capital, he wickedly and harshly brought accusations against king Mondir; on hearing which the king was filled with extreme indignation, and planned how best he could lay a trap for him, and cause him to be arrested, and brought to Constantinople. A means soon offered itself, in the presence at the capital of a Syrian curator, named Magnus, who was the friend and patron of Mondir, and on whom he depended to make his defence before the king: but wishing to curry favour with Tiberius, he said, 'If you give me your command, I will bring him here in chains.' At this proposal the king was pleased, and gave him the wishedfor commission; upon the receipt of which he proceeded to the East, to a town named Churin, which he had himself founded, and surrounded with a wall, and erected in it a church, the consecration of which he made his pretext for paying the town this visit: and he took the patriarch of Antioch with him, that he might the better deceive Mondir, and prevail upon him to come. On arriving there, he sent a message to Mondir, saying, "I have come hither for the consecration of this church, and had it not been for my being tired with the journey, I should have gone and paid my respects to you. But as I wish to see how you do, I beg of you at once to pay me a visit: but do not bring a large 
escort, for I wish you to stay with me several days, that we may enjoy one another's company; and as I should not wish you to be put to great expence by coming with a large army, I pray you bring only a few with you.'

III. 4r. On receiving this missive, Mondir was greatly pleased; and having the fullest confidence in Magnus, as his dear friend, he set out immediately without delay, attended by a very small escort, not having the slightest suspicion that any danger could befall him at his hands. And Magnus, anxious to conceal his wicked schemes, received him with a show of friendship, and gave order's for a great banquet to be prepared. He then said, "Send away these people who have come with you.' But he replied, 'I have come, as you requested me, with but a small escort; but on my return, I cannot travel without having an armed force witl me, even if it be but a small one.' But he pressed the point, and said, 'Send them away; and when you return, you can send for them, and they will come for you.' And as Mondir was a man of considerable experience, the matter did not please him, and he began to be suspicious, and sent orders to his escort to remove but a slight distance from him, and await his coming. On their dismissal, Magnus gave directions to the troops whom he had secretly with him, to hold themselves in readiness, and the general he commanded to remain in his company. And when evening arrived, he said to Mondir, 'My lord Patrician, you have 
been accused before the king, and he has given orders for you to go to the capital, and make your defence there, and prove to him that nothing that is said against you is true.' But Mondir replied, 'After all the services which I have rendered the king, I do not think it right that accusations should be listened to against me. For I am one of the king's vassals, nor do I refuse to go and appear before him : but I cannot possibly at this time break up my army; for if I do, the Arabs, who hold allegiance to the Persians, will come, and take my wives and children prisoners, and carry off all that I have.' But at this moment the Roman troops appeared in arms; and Magnus angrily said to him, 'If you will not go of your own accord, I will throw you into chains, and mount you on an ass, and so send you.' And when now the fraud was plain, and he saw that his friend had stripped him of his escort, and made him a prisoner, and delivered him up to a Roman army to guard him, he was distressed and broken hearted, like a lion of the wilderness shut up in a cage. And when his escort heard what had happened, they surrounded the fort, and prepared to set it on fire: but when the Romans shewed themselves, and made ready for battle, they withdrew ; and Mondir, accompanied by a strong guard, was removed from the fort, and arrived in safety at the capital. And on reaching it, the king gave orders that he should have the same dwelling set apart for his use, as on the previous occasion when he was at Con- 
stantinople, and an income assigned him: and so he remained there without being admitted to an audience, but had with him one wife, two sons, and a daughter.

III. 42. At home Mondir had left four sons, the eldest of whom, named Noman, was a man of even greater intelligence, and more warlike spirit than his father; and with his brothers he assembled his forces, and fell upon Magnus' fort, who had, however, himself returned to the capital; and, excepting the people whom they either took captive or slew, and what they burnt, everything else they plundered and carried away, gold and silver, and brass and iron, dresses of wool and cotton; corn, wine, and oil ; troops of baggage animals of all kinds, whatever fell into their hands, and herds of oxen, and all their flocks of sheep and goats. And from thence the hosts of the Arabs overran and plundered the whole country of Arabia and Syria, and the neighbouring regions, and gathered immense wealth and booty without end: and retiring into the heart of the desert, they there pitched their tents in great numbers, and divided the spoil, being constantly on their guard and ready for war, and on the watch on all sides. And then sallying out again, they plundered and spoiled, and withdrew into the desert, until the whole country of the East to the shores of the Mediterranean was in terror at them, and fled for refuge to the cities, and did not dare show themselves before them. And when the princes of the land, and the com- 
manders of the Roman troops sent to them, saying, 'Why do ye all these evils ?' they sent back the question, 'Why did your king lead our father into captivity, after all the labours, and victories, and feats of valour which he had bravely wrought for him, and has also cut off our supplies of corn, so that we have not the means of living? This is the reason why we are compelled to do these things, and you ought to be well contented that we do not kill you, and destroy everything with fire.' And finally, they went against the city of Bostra, and blockaded it, and said, 'Surrender to us our father's armour, and all the other royal property which we deposited with you: and if not, we will root up and burn and slay everything which we can both in your city and your land.' And when the commandant, who was a man of note and fame, heard these things, he was very angry, and gathered his troops together, and sallied out, despising them as roving Arabs: and they set themselves in array against him, and overpowered and slew both him and large numbers of his men. And when the citizens saw it, they were terrified, and sent out to them, begging them to desist from pillage, and we, said they, will give up what belongs to you, and take it in peace. And so they brought out to them their father's property, upon the receipt of which they retired to their encampment in the desert; but still for a long time they continued to spoil and plunder all the country round about.

When the news reached Tiberius of the active III. 43 . 
vengeance of the sons of Mondir, he was greatly annoyed, and gave Magnus orders to proceed immediately to the East, and use his endeavours to place a brother of Mondir upon the throne of the Arabs in the stead of their rightful chief: and if further he could get Mondir's sons into his power, whether by fraud, or by blandishments and flatteries, or by war, he was to seize them. And to support him in these measures, the civil and military governors of the cities in the East received orders to acrompany him with a large force. He entered therefore upon his mission with great pomp, and was so far successful as to make Mondir's brother king; but ten days after death overtook him, and deprived him of the power of committing any further frauds.

The unfortunate loss of thirteen chapters of the manuscript leaves us in ignorance of the manner of his death, and of the subsequent fortunes of Mondir, except so far as we can gather them" from the headings prefixed to the third book. We learn there, that three other chapters were occupied with Mondir's history, giving an account of his imprisonment, and his being finally sent into exile into a distant country, whither he was accompanied by one of his chiefs named Sergius, a believer; and that his son Noman subsequently came to the capital, but for what reason is not stated. We further learn, that the orthodox enjoyed a time of peace and quiet after the death of Eutychius; but in common with all the people 
of the capital, suffered first from a famine, which unexpectedly visited the city, and subsequently from a terrible mortality, which was especially fatal to children. These lost chapters also contained an account of the death of Tiberiuse, and of his plan for bringing about the unity of the church : and further mention the hostility of his wife to the orthodox, ascribed to her want of knowledge of the true nature of their doctrines. A chapter is also devoted to the three queens, who, after 'Tiberius' death, all inhabited the same palace. Further, there was an account of John the Faster, who succeeded Eutychius as patriarch, and of the gentleness of his character, and great liberality : and, finally, of his endeavours to suppress the heathens. The first five chapters of the fourth book are also lost: and as the table of contents has perished with them, we are left in entire ignorance of their nature.

e Theodosius Melitenus says that he was murdered by means of a dish of early and very fine mulberries which had been poi-

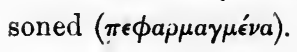




\title{
D I S S R TATION
}

\author{
UPON THE
}

\section{ARABS OF HIRAH AND GHASSAN.}

ThE interest taken by our author in Mondir, son of Harith, arose chiefly from his being a Monophysite, and not only did the oppressed members of the party find a hospitable retreat at his court, but his services were always ready to intercede in their behalf. As, however, his statement differs considerably from the conclusions of M. Caussin de Perceval, it is necessary to enter at some little length into the history of the Arab courts of Hirah and Ghassan.

The Arabs of Syria and Mesopotamia played, during the fifth and sixth centuries, a very important part in the constant wars between the rival empires of Persia and Rome. Their religious differences, however, divided them into two parties, which the diplomacy of the Greek emperors managed generally to engage in mutual feuds. Of these two divisions, the more powerful family of Hirah followed the fortunes of Persia, while the Ghassanide princes combatted on behalf of Rome.

According to the Arabic authorities of M. Caussin de Perceval it was Mondir IV, son of Mondir III, who in 576 went to Rome, and agreed to join his arms with Maurice to oppose his former suzerain Khosrun Nushirwan, whose power had been broken at the battle of Melitene. In 580 he returned loaded with presents by Tiberius, and joined Maurice, who had passed the Euphrates at Circesium, and intended to strike the Persian capital, Ctesiphon, itself. His course lay through the deserts of Mesopotamia, inhabited by warlike tribes, more or less in subjection to Mondir; 
but the latter had changed his mind, and sending a fleet courier to Hormizdas, the son of Khosrun, informed him of the designed attack : and was confirmed as his reward in the kingdom of Hirah in opposition to his brothers.

According to the Arabic authorities he was killed shortly afterwards at Ayn Obagh by the Ghassanide Arabs; but the Greek writers assert that he was only taken prisoner there and sent to Constantinople, whence he was banished by Maurice to Sicily. Of the treason employed by Magnus no record is found in either Greek or Arabic writers.

In the account of M. de Perceval, Mondir was succeeded by a son of that name, whose fortunes occupy a considerable space in the narratives of Arabic historians: whereas John of Ephesus says that Magnus succeeded in placing, not his son Noman, but a brother of Mondir upon the vacant throne. Before settling the question between the two authorities, it may be expedient to give some account of the two dynasties.

The word Hirah signifies a Camp, and its origin is ascribed to a Himyarite king, who left a division of his forces encamped there while pushing his conquests in central Asia. It was situated about three miles from the site subsequently occupied by Cufa ; and it seems probable that a branch of the Euphrates flowed near it, while in its rear was the desert. Its date is of uncertain antiquity, but it certainly existed in A. D. 205, as it was then conquered by the Arsacide Sapor, i. e. Schah-pour, 'the king's son.'

Its prosperity, however, commenced about A. D. 272, when, upon the fall of Zenobia, the Arabs of Hirah contrived to reduce under their dominion several of the tribes of Mesopotamia who had previously obeyed her. And we still find in John's history the Mesopotamian Arabs obeying the princes of Hirah, as vassals of the Persian king.

Christianity probably was soon partially received there, but it made no rapid progress until the reign of Nonan. In his time, about A. D. 4 IO, the fame of Simon Stylites caused numerous Arabs to wander to his pillar in Syria, and Noman, fearing they might be won over to the Roman side, furbade these pilgrimages. 
The saint, however, attended by two acolytes, appeared to him in a dream, rebuked him severely, and ordered the acolytes to scourge him. The dream was so vivid, that upon awaking in the morning he found himself covered with the marks of their blows, and being thus divinely warned, he revoked the edict, and gave free permission to the Christians to build churches, and perform the rites of worship in his dominions.

Cosmas, who details this story (Ass. B. O. I. 247', says that he had it from a Roman governor Antiochus, who was told it l,y Noman himself, when the latter, in a time of peace, being near Damascus, invited Antiochus to dine with lim ; and after many inquiries concerning Simon Stylites, informed him at length of the reason which prompted his curiosity.

It is further added, that he became himself a Christian; and this is confirmed by the story told by Arabic writers, that when walking one day on the roof of his palace admiring the splendour of his city, and the beauty of the neighbouring country, the thought that he must soon abaudon it to another, struck him so forcibly with the uncertainty of all human things, that he descended, changed his garments, and retired into the desert, where he spent the remainder of his life in meditation.

The most powerful monarch of Hirah was Mondir III, father of the supposed false ally of Maurice. Of him M. Perceval gives abundant proof that he was not a Christian, and that Christianity had really made very little progress among his people; and the same would follow from his constant wars with the Romans. During a reign of nearly fifty years the life of this prince was spent in ceaseless battle. Restless and indefatigable, at one time falling suddenly upon his personal enemies, at another ravaging the Roman territories far and wide, he did not even fear to give battle to Belisarius, and came off undefeated. In Theophanes he appears as the 'A $а$ a and penetrated to Chalcedon; and his advice to the Persian monarch, after the defeat of Dara, was to leave Mesopotamia and the military confines alone, and strike at the peaceful centres of the Roman dominions. His whole life and character is a picture of that Arab activity, already forecasting the empire of the world, 
and destined so soon to gain the ascendant over the two exhausted kingdoms of Persia and Rome.

It excites no wonder that Justinian bought peace of such a chieftain at the price of an annual subsidy. But the death of his son Amru, (whose murder by a poet of the same name, for an insult to his mother, forms so celebrated a subject in Arabic literature,) led to family feuds : and the rapid succession of Noman IV, Cabus, and finally of the Mondir, to whom M. de Perceval assigns the treachery complained of so bitterly by Maurice, weakened the power of Hirah ; and, after becoming a Persian satrapy, it finally fell before the arms of Khalid, general of the Caliph Abu-becr, and was merged in the empire of Islam.

Except Mondir IV, the princes of Hirah were the constant enemies of Rome : but the case is far different with the Ghassanides. Of their origin little is known, but about the time of Constantine they embraced Christianity, and became therefore the allies of Rome. One, however, of their sovereigns, the queen Mawia, broke the alliance, and fought so successfully against her former friends, that Valens, circa A. D. 377, was obliged to sue for peace: upon which she assisted him bravely against the Goths. Their history henceforward is without interest until the time of Harith (Aretas), whose son Mondir is the prince spoken of by our author.

Harith reigned from A. D. 530 to A. D. 572 , and is the person described by the Byzantine historians as Aretas, king of the Christian Arabs. In Asseman's Bibl. Or. his name frequently occurs, and, as in our author, in connection with Sergius and Paul, the two first Jacobite patriarchs. In spite of his Monophysite creed, Justinian honoured him with the titles of patrician and king, on account of his valuable services to the Roman empire in holding the kings of Hirah in check. His troops fought under Belisarius at the battle of Callinicus against Mondir III, and soon after he endeavoured single handed to avenge the Roman general's check, but was so utterly defeated that Justinian had to interfere to save him from ruin... Again, in $54 \mathrm{I}$, he joined Belisarius in an invasion of Persia, but the plundering propensities of his men ruined the whole expedition. In spite 
of the disgrace into which he fell at Rome on this account, he nevertheless gradually increased in power, and earned among the Arabs the title of 'the Magnificent :' and in $5^{62}$ we find him in person at Constantinople, to obtain from the Roman emperor, Justinian, the confirmation of his son in his dominions; and the title given him by Theophanes, who records his visit, is, 'A éćas

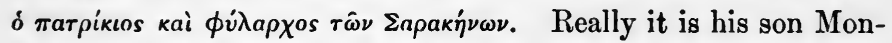
dir, and not Mondir of Hirah, to whom our author so frequently refers in his narrative.

The last king of Ghassan, Jabala, after a defeat, embraced Islamism, and submitted to the caliph Omar in A. D. 637 .

Now it is exceedingly probable that M. de Perceval may have interchanged the two Mondirs, as his Arabic authorities are so confused that it is scarcely possible to draw out of them a connected narrative : and besides, they are many centuries subsequent to the times of which they write. The arms of Islam had obliterated all traces of the kingdoms of Hirah and Ghassan, and powerful cities had grown up on their sites hundreds of years before the princely Abbassides called forth a crowd of Arabic writers to chronicle the past exploits of their race : and of these, most felt no interest in any thing which occurred before the birth of the prophet. While in his Greek authorities there is nothing to decide which Mondir it was who was banished to Sicily.

But it is quite incredible that John of Ephesus, a contemporary writer, could have confounded the two chiefs. For he was the personal friend of the man of whom he wrote, and looked up to him as the hereditary patron of his party in the East. He had returned moreover to Constantinople from his banishment two years before Mondir's departure from that city upon his first visit, and narrates his efforts to reconcile the Monophysites themselves, rent into parties by the quarrel between the patriarch Paul, and Jacob Zanzalus : and also his intercession with Tiberius in their behalf, and his successful attempt to put an end to the persecution of his friends by Eutychius, and the bishops in the East. He was too at Constantinople when his friend was brought there as a prisoner, and 
probably had his account from one of his suite. Moreover, the very plea on which Magnus allured him into his power, namely, the consecration of a church, shows that he was a Christian, whereas Mondir IV. of Hirah was a heathen: nor would he have fallen so unsuspiciously into the hands of the Romans, as for centuries his family had been at war with them, and consequently had neither friends nor patrons there, nor any such intimacy as lulled the other Mondir's fears. And besides, John says that Magnus succeeded in placing Mondir's brother upon the throne, in the place of Noman his son : and accordingly M. de Perceval makes Mondir, son of Harith, to be succeeded by his brother Jabala, whereas Mondir of Hirah was succeeded by his son Noman. John's narrative further explains also the unaccountable disappearance of Mondir, son of Harith, from the Arabic histories, whereas Mondir of Hirah was slain, they say, at Ayn Obagh.

And, in short, if, as Dr. Land thinks, John of Ephesus really confounded the two Mondirs, and describes a heathen as allured to the consecration of a church, and the pleasure of meeting the patriarch of Antioch, and tells moreover a story, every part of which is applicable to the Ghassanide Prince, and no part to the Lakhmite at Hirah, he will have been guilty, not merely of stupidity, but of an amount of wilful misrepresentation and invention, which will throw complete discredit upon every part of his history. 


\section{BOOK THE FOURTH.}

The loss of most of the first five chapters of the fourth book of John's history has deprived us of the prefatory matter respecting the persons employed in the mission for the conversion of $\mathrm{Nu}$ bia, and probably of several details respecting the church of Alexandria, which had long been the head quarters of the Monophysites; as also concerning its patriarch Theodosius, who was deposed for belonging to this heresy, but survived for a period of rather more than thirty-one years,

IV. 5. during which he still administered the affairs of his party, and directed the consecration of new priests and bishops, as occasion required. In the discharge of these duties he was subsequently joined by Paul, patriarch of Antioch, whose fortunes and flight to the court of Harith, father of Mondir, have been detailed above. In the latter years, however, of Theodosius' life, as on account of his great age and feebleness he was unable to stand at the consecration of the Eucharist, a priest, named Longinus, was appointed, at his request, to officiate in his stead, and did so during the rest of his life. And it was this Longinus who was finally appointed by him bishop of the Nobadæa, upon their conversion to Christianity, under the following circumstances;

a Procopius de bello Persico, i. I 9, tells us that the Nobata 
Among the clergy in attendance upon pope Theo- IV. 6 dosius, was a presbyter named Julianus, an old man of great worth, who conceived an earnest spiritual desire to christianize the wandering people who dwell on the eastern borders of the Thebais beyond Egypt, and who are not only not subject to the authority of the Roman empire, but even receive a subsidy on condition that they do not enter nor pillage Egypt. The blessed Julianus, therefore, being full of anxiety for this people, went and spoke about them to the late queen Theodora ", in the hope of awakening in her a similar desire for their conversion; and as the queen was fervent in zeal for God, she received the proposal with joy, and promised to do every thing in her power for the conversion of these tribes from the errors of idolatry. In her joy, therefore, she informed the victorious king Justinian of the purposed undertaking, and promised and anxiously desired to send the blessed Julian thither. But when the king heard that the person she intended to send was opposed to the council of Chalcedon, he was not pleased, and determined to write to the bishops of his own side in the Thebais, with orders for

dwelt beyond Elephantine, on the banks of the Nile, but the Blemyes inland: and he adds, that Diocletian had greatly increased their territories, and given them an annual subsidy on condition that they should protect the Roman borders from marauders.

b Bar-hebræus says that at this time Theodosius was dwelling at Constantinople. Cf. Assem. Bib. Or. ii. 330. 
them to proceed thither and instruct them, and plant among them the name of the synod. And as he entered upon the matter with great zeal, he sent thither, without a moment's delay, ambassadors with gold and baptismal robes, and gifts of honour for the king of that people, and letters for the duke of the Thebais, enjoining him to take every care of the embassy, and escort them to the territories of the Nobadæ. When, however, the queen learnt these things, she quickly, with much cunning, wrote letters to the duke of the Thebais, and sent a mandatory of her court to carry them to him; and which were as follows: 'Inasmuch as both his majesty and myself have purposed to send an embassy to the people of the Nobadx, and I am now despatching a blessed man named Julian; and further my will is, that my ambassador should arrive at the aforesaid people before his majesty's; be warned, that if you permit his ambassador to arrive there before mine, and do not hinder him by various pretexts until mine shall have reached you, and have passed through your province, and arrived at his destination, your life shall answer for it; for I will immediately send and take off your head.' Soon after the receipt of this letter the king's ambassador also came, and the duke said to him, 'You must wait a little, while we look out and procure beasts of burden, and men who know the deserts; and then you will be able to proceed.' And thus he delayed him until the arrival of the merciful queen's embassy, who 
found horses and guides in waiting, and the same day, without loss of time, under a show of doing it by violence, they laid hands upon them, and were the first to proceed. As for the duke, he made his excuses to the king's ambassador, saying, 'Lo! when I had made my preparations, and was desirous of sending you onward, ambassadors from the queen arrived, and fell upon me with violence, and took away the beasts of burden I had got ready, and have passed onward. And I am too well acquainted with the fear in which the queen is held, to venture to oppose them. But abide still with me, until I can make fresh preparations for you, and then you also shall go in peace.' And when he heard these things, he rent his garments, and threatened him terribly, and reviled him; and after some time he also was able to proceed, and followed the other's track, without being aware of the fraud which had been practised upon him.

The blessed Julian, meanwhile, and the ambasIV. 7 . sadors who accompanied him, had arrived at the confines of the Nobadæ, whence they sent to the king and his princes, informing him of their coming: upon which an armed escort set out, who received them joyfully, and brought them into their land unto the king. And he too received them with pleasure, and her majesty's letter was presented, and read to him, and the purport of it explained. They accepted also the magnificent honours sent them, and the numerous baptismal robes, and every thing else richly provided for 
their use. And immediately with joy they yielded themselves up, and utterly abjured the error of their forefathers, and confessed the God of the Christians, saying, 'that He is the one true God, and there is no other beside Him.' And after Julian had given them much instruction, and taught them, he further told them about the council of Chalcedon, saying, that 'inasmuch as certain disputes have sprung up among Christians touching the faith; and the blessed Theodosius being required to receive the council, and having refused, was ejected by the king from his throne, whereas the queen received him and rejoiced in him, because he stood firm in the right faith, and left his throne for its sake: on this account her majesty has sent us to you, that ye also may walk in the ways of pope Theodosius, and stand in his faith, and imitate his constancy. And moreover the king has sent unto you ambassadors, who already are on their way in our footsteps.' 'They then instructed them how they should receive them, and what answer they should give: and when every thing was fully settled, the king's ambassador also arrived. And when he had obtained an audience, he also gave the king the letters and presents, and began to inform and tell him, according to his instructions, as follows: "The king of the Romans has sent us to you, that in case of your becoming Christians, you may cleave to the church and those who govern it, and not be led astray after those who have been expelled from it.' And 
when the king of the Nobadæ and his princes heard these things, they answered them, saying, 'The honourable present which the king of the Romans has sent us we accept, and will also ourselves send him a present. But his faith we will not accept : for if we consent to become Christians, we shall walk after the example of pope Theodosius, who, because he was not willing to accept the wicked faith of the king, was driven away by him and expelled from his church. If, therefore, we abandon our heathenism and error's, we cannot consent to fall into the wicked faith professed by the king.' In this manner then they sent the king's messengers away, with a written answer to the same effect. As for the blessed Julian, he remained with them for two years, though suffering greatly from the extreme heat. For he used to say that from nine o'clock until four in the afternoon he was obliged to take refuge in caverns, full of water, where he sat undressed and girt with a linen garment, such as the people of the country wear. And if he left the water his skin, he said, was blistered by the heat. Nevertheless, he endured it patiently, and taught them, and baptized both the king and his nobles, and much people also. He had with him also a bishop from the Thebais, an old man, named Theodore', and after giving them instruction and setting things in order, he

c Curiously enough, traces remain of bishop Theodore of Phyle in some inscriptions discovered by M. Gau, and which are given in the Appendix. 
delivered them over to his charge, and himself departed, and arrived in safety at Constantinople, where he was most honourably received by the queen. And to her he related many wonderful particulars concerning that numerous people, but they are too long for us to write, nor can we spare space for more than we have already inserted.

IV. 8. The chief charge of the new converts was vested in Theodosius, as being patriarch of Alexandria; nor were they forgotten by him: for on the very day of his departure from this world he had them in his memory, and especially because the blessed Julian their teacher had died but a very short time before, and also because her late majesty, the queen Theodora, had given orders that the excellent Longinus should be made bishop there, as being an earnest man admirably adapted to convert and establish them in the doctrines of Christianity. Immediately therefore after the pope's decease, Longinus was consecrated bishop of those parts, and made ready to proceed thither. But scarcely had he embarked his goods on board ship, when men were found, such as Psalm those of whom it.is written, that 'their teeth are Ivii. 4. spears and arrows, and their tongue a sharp sword,' who went and told the king, that 'Longinus, the enemy of our palace, has been made bishop, and has embarked his goods on board ship, ready to start. And should he go, for he is a passionate man, and arrive among that people in safety, he will immediately stir them up to 
make war upon and pillage the territory of the Romans. Give orders therefore for his immediate arrest.' When the king heard these things, he was stirred up to anger, and gave orders for his arrest, and had his baggage removed from the vessel. Thus then he was not permitted to depart, and three years passed by, during which he was waiting for an opportunity; and finally, as he was aware that he was watched, and would not be permitted to leave, he disguised himself, and put a wig on his head,-for he was very bald;-and taking with him two servants, he fled, and God delivered him, and caused him to arrive in safety at that land. And there he was magnificently received, and great joy testified at his coming: and immediately he began to instruct them afresh, and enlighten them, and teach them. And next he built them a church, and ordained clergy, and taught them the order of divine service, and all the ordinances of Christianity. But when the king heard of his flight he was very angry, and gave directions that the ferries over the sea should be all occupied, and the roads watched, and letters written to the provinces; but all proved to no purpose. Longinus meanwhile prevailed upon the king of that people to send an ambassador to the king of the Romans with presents, and gifts of honour. And on his arrival, he had an audience, and was honourably received in the presence of myself and the rest of the court, and spake highly of Longinus, saying, "Though we 
were Christians in name, yet we did not really know what Christianity was until Longinus came to us.' And much more he related, greatly to his honour; but the king retained a bitter feeling against him, though he said nothing.

IV. 9. After Longinus had passed a space of five years, more or less, in Nubia, Satan, who envies everything that is good, contrived a device for driving him away from thence, and producing by his means ruin and schism and disruption in the church. He stirred up therefore Theodosius, the archpresbyter of the clergy at Alexandria, and Theodore, his sister's son, who held the office of archdeacon, to write letters to him, inviting him to quit Nubia, and journey to the suburbs of Alexandria to consecrate for them a pope, and so benefit the church-an act which was the beginning of much mischief and schism. When then Longinus received these letters, he was stirred up, and burnt with earnest zeal; and, despising all danger of death, began to make preparations for his journey, and for fulfilling what was enjoined in the letters. But when the king and his nobles learnt these things, they assembled, and tried to prevent him from leaving them. But he shewed them the letters, saying, "The business for which I am commanded to set out upon this journey is one for the common good of the whole church, and I cannot therefore refuse to go.' And they still tried to prevail upon him, and lamented and wept, saying, ' Once again, as before your arrival, we shall be left like orphans without a fa- 
ther.' But finally, with much sorrow and bitter lamentation, they let him go, and provided him with means for his journey. He started therefore, and went first to Theodore, the venerable bishop of Philæ, in the further Thebais, and shewed him the letters, and took counsel with him as to what was therein written, requesting him, if it were possible, to accompany him on his journey. But he could not, from his extreme old age; for it was now nearly fifty years since he had been made a bishop by Timotheus ${ }^{d}$, the predecessor of the blessed Theodosius: nevertheless he entirely agreed with the purport of the letters, and drew up a mandate appointing Longinus to act as his proxy, and certifying his consent to whatever he did. Thus encouraged, Longinus proceeded on his journey, and arrived at the place in the Mareotis indicated to him in the letters; and now it became a matter of deliberation what he should do next, for he was alarmed and afraid, lest the news should get abroad of his having entered the Roman territories after escaping from surveillance, and orders be given for his arrest; in which case he would die a painful death: and at this his heart was terrified.

Now it so chanced that about this time two IV. ro. bishops, John of the monastery of Marbas, and George Eurtoyo ${ }^{e}$, of whom the latter had just

d This was Timothy III, pope of Alexandria from A. D. $5^{\text {I } 8}$ to 535. Like most of the clergy and people of Egypt, he was a Monophysite.

e This is possibly the person mentioned in Ass. B. O. ii. 63 . 
been consecrated, but not yet permitted to perform episcopal functions, had been sent by the synod of the East to Longinus, and to the abovenamed Theodore of Philæ, to consult them respecting the reception of Paulf, patriarch of Antioch, into the church after his temptation and flight; and to learn whether they consented to admit him once again to communion and union. While, however, they were making their preparations to proceed up the Nile on their journey, they learnt that Longinus had left his

f It may not be without its use to compare the full account of Paul as related by our historian with the compendium given by Asseman, as we thus learn how different a complexion is given to history by the filling up of the outlines. His narrative, B. O. ii. 331, is as follows: 'Paul of Alexandria, after putting on the monkish dress, was for some time with Theodosius, the patriarch there: but after the death of Sergius, being ordained patriarch of Antioch by Jacob Burdoho and two others, he was driven away from Egypt by Athanasius, Theodora's grandson, for endeavouring to oltain the patriarchate of Alexandria, and fled to Harith, king of the Arabs. Thence having gone to Byzantium, he was prevailed upon by the Emperor's services to embrace the council of Chalcedon. But on his return to Syria, he sent in a petition to Jacob Burdoho, begging to be received back into the Monophysite communion; and his request being supported by the prayer of Mondir, the son of Harith, Jacob admitted him on ejuring the true religion.' The nature of the Emperor's good services we have seen before, and it is a proof of the strictness of discipline then enforced that so much difficulty should have been experienced by Paul in obtaining readmission to his own party, after a submission extorted by such violent means : and it also explains the patience with which men like Stephan of Cyprus, after being flogged into communion with the church, abode by the step they had taken. 
see, and come down to Egypt: and following in his track, as hearsay guided them, they at length found him in Libya, outside Alexandria, in a place called Mareotis. And he received them with joy, and on reading their letters, he was glad, and said, 'God has happily brought you hither, chiefly that you may give us a helping hand in the establishment of the church. For this is the purpose for which I also, being invited by letter, have travelled to this place from a distant land, in order that there may be a patriarch of Alexandria.' And they said, 'But how can we make a patriarch without the command of our own patriarch? If therefore this is your wish, let him by all means be found, for he is not far off; and we will go and bring him.' After much discussion, therefore, they went and brought into Libya Paul the patriarch from some place, as was said, in the neighbourhood, where he was dwelling disguised as a Roman. And on their return, they found Longinus actively engaged in going from place to place in search of a fit person for the office of archbishop. And on joining him, they travelled in his company to the desert of the hermits, beyond the blessed Mar Minas ${ }^{\mathrm{g}}$, to a place called Rhamnis; and they

g In Quatremère's Mémoires sur l'Egypte, i. 489, a description is given of the church of St. Minas, taken from an Arabic MS., which well illustrates the magnificence to which the hermits in the Nitrian desert had attained. According to this account, the church of St. Minas was a vast building decorated with statues and paintings of great beauty: wax tapers burnt therein day and 
found the abbot there to be a most excellent man, named Theodore, by birth a Syrian; and to him they addressed themselves, begging him to yield himself up, and consent to be made pope of Alexandria. But he, on hearing the proposal, was terrified, and refused, and fled from it, even taking solemn oaths, and condemning himself utterly, should he consent: but on their threatening him with excommunication if he persisted in his refusal, he was forced by violence, against his will, weeping and lamenting, to consent to their request: and thereupon, Longinus

night without interruption. At one end was a massive tomb, with two camels sculptured in marble, on which a man stood upright, with his feet resting upon the camels' backs. He held one hand open, and one closed. This figure, which was also of marble, represented, they said, St. Minas. In the same church were the statues of John, Zacharias, and of Jesus, placed inside a vast colonnade of marble, situated on the right-hand side of the entrance : and in front of them was a gate kept constantly closed. There were also the statues of the prophets, and of the Virgin Mary, concealed from view by two curtains. On the exterior of the edifice were statues representing all sorts of animals, and men of all professions : among them a slave-merchant, with a purse in his hand with the bottom out. In the centre of the church was a dome, underneath which were eight statues, representing, if what they said is true, the angels. The land round the church was planted with a multitude of fruit trees, especially almonds and carob trees, the fruit of which being sweet and sugary, was used in making sirops. There were also numerous vines, the grapes and wine from which were exported into Egypt. The author subsequently adds, that the town of Fostat every year sent a thousand dinars to maintain the church.

In this desert, callerl also Scetis, and Scete, the monkish popu- 
and the two other bishops consecrated him, Paul, as they affirmed on oath, not being near, nor taking part in his ordination, because at present he was not absolved from his fall, nor admitted back into communion. But though unable to take part in any other way in his ordination, he subsequently gave it his approbation, and received him, and communicated with him, and, as was said, they even addressed a synodical letter to one another, as patriarchs respectively of Antioch and Alexandria. And when now all imagined that, in accordance with the canons, they had performed a great work for the union and establishment of the church of Syria and Alex-

lation was so dense, that seventy thousand, with their staves in their hands, are said to have met Amrou-ben-el-as, on his return from Alexandria, to beg him to take them under his protection : which he did, and granted them moreover a yearly allowance of five thousand ardebs of corn levied on Lower Egypt.

On the mountain of Nitria itself, in the early ages of Christianity, there were nearly fifty monasteries, besides fifteen hundred hermits, subject to the authority of a superior. They did not, however, all follow the same mode of life, but might either dwell absolutely alone, or in pairs, or even in greater numbers. Seven bakeries were constantly employed in supplying the hermits with bread; there were also physicians, pastrycooks, and places where wine was sold. At the chief church on the mountain there were eight priests, the first of whom alone had the right to celebrate mass, to preach, and judge in cases of quarrel. Every Saturday and Sunday the hermits came to church. Just by was a hospice where they received strangers, and maintained them as long as they chose to stay, even if it was for two or three years : but after the first week, they expected them to undertake some kind of employment. (Ibid. p. 485.) 
andria, because the bishop was made without the knowledge of the Alexandrians, - a thing which justice forbade,-it proved the ruin of them all, and of the whole church of the East, and of the Egyptians; and a source of trial and confusion and quarrels, and schisms, and divisions, and the cause both of manifold evils to themselves personally and individually, and a pretext to the savage people of Alexandria for giving way to excessive and unrestrained fierceness and barbarity.

IV. Ir. For when the Alexandrians received the letters of Longinus, and of the bishops who were with him, and subsequently of Theodore himself, giving an account of all they had done, and informing them that Theodore was their patriarch; and when further, as in duty bound, he addressed to them his synodic letter, chiefly. to assure them of his soundness in the faith, but also containing such other matters as were fitting for him to write to his church; and among them an apology, in which he alleged his fear of the authorities, and of there being a disturbance, as his reason for not having come in person to their city, that every thing might be done in canonical order, and with their consent and decree; - when the chiefs, I say, of the clergy, whose names have been given above, and the rest, heard these things, they were greatly excited and agitated and enraged at every thing that had been done: and stirred up and inflamed the other clergy to the like fury and savage vio- 
lence against Longinus and Theodore, and even more fiercely against Paul, on whose account especially it was that they spurned and reviled and rejected the rest, and cried out both in the church and city against them in a disgraceful and disorderly manner, saying, 'Let us at once assemble without delay, and make us here a pope of our own selves.' At length they proposed the name of a certain Andronicus, whom we have once before mentioned ${ }^{\mathrm{h}}$. But in this their real purpose, as was said, was, that they might have full and unlimited power over the revenues of the church of Alexandria. When, however, they became aware that neither the clergy nor the laity would be content with him, because report said that a devil a short time before had appeared unto him; and as he himself now gave signs of declining the appointment, having fallen from their hope of electing one of themselves, they next fell upon the abominable artifice of nominating a contemptible and inefficient man, intending that he should possess nothing more than the name and dress, being prevented by his ignorance and simplicity from taking part in the administration of

h Probably in the lost chapters at the beginning of this book, as no mention is made of him in any of the extant parts. A word occurs just before cen;.9lo which I am unable to translate. It does not belong to the Syriac language, and as nothing suggests itself in Greek, I have omitted the sentence : the construction apparently requires that it should be the name of some class of people, or order in the church, as it says that Andronicus belonged to them. 
the revenues, and those other duties which befit so princely an office: for they supposed that they could command, and turn him about and manage him as they chose, while he would not be able to command them. And this plan they succeeded in effecting: for they chose a simple and ignorant old man, named Peter, who belonged to the ordinary class of deacons, and who had been one of the companions of the blessed Theodosius in his exile, and proposed him as bishop. And on their determining to appoint him, only one bishop, a certain John, could be found to consecrate him, and even he was himself waiting his trial for some canonical offence. And when they knew not what to do next, two foreign bishops arrived, who had lately been consecrated for the church of Syria by the blessed Jacob, and who, it so happened, both bore the same name of Antoninus; and on them they laid violent hands, and made them consecrate the deacon Peter as bishop, though there was at the time another in possession of the throne, and they had themselves received his synodic letters. And without examination and trial, as order and the canons command, or making inquiry whether his appointment had been conducted in a proper manner, and according to the canons, or in violation of them, they were roused to bitter anger, and iniquitous contrivances; for their wrath led them into a course marked by savage violence and barbarous fury. And thus they made and appointed a second bishop upon the same throne from their 
hatred to the first, causing thereby disturbance and confusion, and schism and quarrel, in the whole church. And, in fact, as the result shewed, it was done at the will and pleasure of the devil, who was the real instigator of these things, and who led them on as being a vindictive and intemperate people to so great turbulence and savageness, that no single thought of order entered their minds, or of the duty of judging and examining whether the former appointment had been made fittingly or not, as Theodore supposed they would do on hearing the news of his creation. Instead of this, they took so extreme a course as to appoint another in his place. Had their violence been bridled by the fear of God, they would have understood of themselves the mischiefs and schisms, and divisions and disputes, and struggles and disturbances, which they were about to occasion in His church : instead whereof their evil purpose was accomplished, and the quarrel so begun continues to this day, though eight years, more or less, have now elapsedi. And to describe all the fightings which have sprung forth from this source, the mutual quarrels, the unappeasable hatred which has taken possession of many hearts, would require the lamentations of Jeremiah, the prophet of grief: for sense and moderation seem entirely lost, nor can they restrain themselves from utter-

i This chapter must have been written therefore A. D. $5^{8} 5$, in the second year of the reign of Maurice. 
ing reproach and contumely, and bitter calumnies against one another.

IV. r2. Just therefore as a man who is weak and diseased in his eyes, cannot easily see with accuracy, and search for any thing in the rays of the sun; and again, as one who is burning with fever cannot do any thing whatsoever like a healthy man; so also those who are hurried away by passion, and dragged along by the fury of an angry zeal, can . neither discern nor judge what is fitting, nor thereby regulate their conduct. And so also neither can those who are intoxicated with heat, and agitated with wrath and the spirit of opposition, either purpose or execute any thing whatsoever in a firm and steadfast manner. And this in fact happened to the wise clergy of Alexandria: for they were by no means men of inferior merit, or without knowledge, had not the gall of anger agitated them, and wrath made them stumble; and yet they lived to be an example of the Scripture, which says of those tossed by waves and winds and tempests, that Ps. cvii. 'they shook and reeled like drunken men, and 27. all their wisdom perished.' For so in their hasty and uncanonical proceeding, when the synodal letter reached them, informing them that a bishop had been consecrated for them by those who were orthodox like themselves, and members of their communion, because, owing to the urgency of the times, it was done without their vote, they took so violent a course as to seize upon and consecrate Peter as the second bishop, at the 
same time upon the same throne. Whether this was right, any one may judge, who considers that during the whole space of ten years, which had elapsed since the death of the blessed Theodosius, they might have created for themselves a bishop without dispute; whereas they waited until the news reached them of the appointment of Theodore, and then made an election in anger, to be a cause of quarrel and dissension and schism in the church; for Peter, whom they elected, was immediately regarded by many as an adulterer, who had entered in unto his neighbour's wife ${ }^{k}$. And moreover, to strengthen his position, they persuaded this second prelate, thrust contrary to church-laws and canonical order into another's throne, to consecrate no less, as was said, than seventy bishops; though were a man but seeking for labourers to till his fields, he would find it no easy matter to bring together at one time so many men fit for his purpose. What then shall we say of those who were chosen to feed Christ's rational flock, according to the

k This phrase was applied in the early church, not merely as in the present case, to a bishop elected to a see already filled by another, but even to one who deserted the bishopric to which he was first appointed, even though it was for a patriarchate. Thus when Epiphanius, patriarch of Constantinople, died in 535, and Anthimus, bishop of Trapezus, was translated to the see, Agapetus, pope of Rome, 'Constantinopolim de Roma adveniens, Anthimum ecclesia pellit, dicens eum contra regulam adulterum qui sua ecclesia dimissa, ambierat alienam.' Com. Marcellinus in Chronico, Indict. xiv. 
commandment given to the blessed Peter, 'Feed my sheep :' and of whom the apostolic rule and instruction to Timothy was, that with much care and enquiry and examination he should select those whom he appointed to the priesthood only, and how much more then those who are heads over the priests? And as the beginning of the matter was troubled and confused, and contrary to established precedent, so was its end. For even so no check was put upon his hasty course of violence, nor did he clothe himself in the quietness and gentleness of Christ, but let them hurry him into malignant proceedings, which caused a schism between the churches of Syria and Alexandria: for he ventured unjustly and uncanonically to depose Paul, who by the command of the blessed Theodosius had been consecrated patriarch of Antioch, and this too in his absence. Nor merely so, but he must needs bring accusations against Jacob, bishop of Syria, and even publish them in a circular letter, which he sent about in all directions: in which, from the old enmity and feud of the Alexandrians against Paul, he inserted a number of murderous and lying slanders, to the effect that Paul and his party had communicated with the Synodites. But those whom he calumniated solemnly abjured the charge, in the defence which they jointly addressed to the whole church, and in which they anathematized the authors and publishers of the scandal, and themselves, if ever knowingly and consciously, either in secret or in 
public, they had been guilty of the act of which they were accused.

And though I thus write, let no man imagine IV. I3. that either here, or in what I shall hereafter relate concerning this turbulent affair, my purpose is to indulge in slanders, or to say any thing untrue, or even superfluous, in the hope of gaining for the one side the victory, and of throwing blame upon the other. My sole object is briefly to record the events which happened in the year 886 of Alexander (A. D. 575), and subsequently: adding nothing to them, though we will not promise not to curtail them; for the confusion and turbulence and irregularity wrought by the contrivance of the enemy of mankind exceeds all measure, nor can we do more than give a short sketch of it, classing it all under the title of disorder. But to return to our narrative. When Theodore, who had been consecrated bishop of Alexandria against his will, by Longinus and the rest, learnt that the Alexandrians had behaved thus violently and savagely, and had refused to receive either him or his letters, and contrary to all canonical order had even appointed the above-named Peter after his election, and in his stead, he remained quiet, and continued to observe the rules of his former habit (as a monk), nor did he allow himself to be disturbed by what had happened, saying, 'Let there be no schism, and no quarrel, on my account; for my sole care is to live in peace, as I have done unto this day.' And so he con- 
timued for awhile to avoid all agitation; but when in process of time many, both in the city and in the deserts, and in Egypt and the Thebais, came over to him, he also appointed vicars in his own name, and ordained priests ${ }^{l}$.

IV. I4. Far different was the conduct of the other side, as regards both the patriarch Paul and Jacob. Of the former we have already given in the Second Book at full length an account of the fall, into which he was betrayed by the hope of unity: and now we have to tell how the people of Alexandria became possessed of the vain idea, that attended by his bishops he had travelled into Nubia, and there with Longinus had consecrated Theodore: whereas Longinus, in a letter which he sent in his defence, declared that this was false, and denied with solemn adjurations that Paul was either present at Theodore's consecration, or a party to it by word or privity. Nevertheless they prevailed on Peter, in their savage violence, audaciously to pronounce sentence of deposition against him, in violation of all canonical order; by which in fact his own consecration was illegal and invalid, inasmuch as he was the second appointed to fill a throne already occupied, a thing which the rules and canons of the church forbid. And moreover

1 I imagine that If-reses is the Greek word ovyкpiral, which occurs in the life of S. Theophylact, bishop of Nicomedia : 'coming to Constantinople, he was slave first of all to the most holy

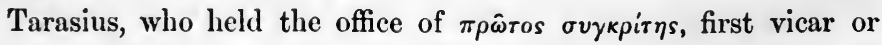
assessor in the patriarch's court.' 
they invented charges against the blessed Jacob, and, not content therewith, published them in circular letters. And this was done in the absence alike of Paul and Jacob, who were not cited as the canons require, nor were the charges brought against them in their presence, that so sentence might follow according to what they had done. And this proceeding of the church at Alexandria led to a bitter schism between them and Syria, and was itself the result of an old grudge which they harboured against Paul.

It may perhaps not be out of place here to say IV. I 5 . of the simplicity and innocence of the old man Jacob, that which is written in the Scriptures, concerning the brethren in the days of the blessed apostles, that ' in the singleness of their Acts ii. heart they praised the Lord.' For he, like them, ${ }^{46}$. to simplicity and innocence, joined great spiritual zeal, and from his youth, even unto old age, was indefatigable in his exertions and labours for the church. He was however too much under the influence of the crafty and designing men about him, who turned him every way they chose, and used him as a means of establishing their own power, swaying him now in this direction, and now in that, like a child. And so it was in the case of Paul, who originally had been consecrated by him and the rest, patriarch of Antioch the Great, and thereby elevated to be their own head and ruler: but when after his appointment they still continued to conduct matters at their own discretion, and without consulting 
him; and others at length represented to them, that it was not right to act without the judgment of their patriarch, the rebuke greatly displeased them, nor would they even so desist from managing every thing as they chose. When then subsequently Paul and the other leading bishops were summoned to the capital, in the hope of establishing the unity of the church, and had arrived there, and been received by the king, many long discussions were held, and consultations, which extended over a period of more than two years, and of which we have recorded the leading particulars in the Second Book, and therefore think it better now to pass them over. Finally, however, Paul and the three others with him, through too great confidence in the oaths and declarations of those in power, were betrayed by their too eager hope of union into lapsing miserably into the communion of the two natures: and after much had passed, of which an account has been already given,- and they had been all sent into banishment, Paul, setting his life at nought, fled from the palace, and was delivered from the hand of his enemies, and hastened unto Syria, where he laid his act of penitence before the synod of the East, and not content with one petition, sent also a second. And he continued as a supplicant for the space of three years, more or less, and then was duly and canonically received into communion by the blessed Jacob and his synod. Whereupon Jacob wrote letters, both to us at the capital, and to 
Antioch, and to other quarters, as follows:'Learn that we have received our blessed patriarch, the lord Paul, into spiritual communion; and we have taken the sacrament together: and every one who receiveth him, receiveth us; and every one who receiveth not him, receiveth not us.' And yet after a little time, by the contrivance of the evil one, various accusations were stirred up between them, which we for their habit's sake shall hide in silence.

The enmity and division between the two parties, and their mutual criminations concerning the disorderly proceedings at Alexandria, continued for a considerable time; and the blessed Jacob was especially active in writing in all directions in opposition to Peter, the second bishop consecrated to the see, and described him in his letters as a new Gaianus ${ }^{m}$, who had

m On the death of Timothy, patriarch of Alexandria in A. D. 518, a double election took place, two persons, Gaianus and Theodosius, being chosen by the people, both opposed to the synod of Chalcedon, but differing upon a question, greatly agitated at that time in the church, Gaianus holding that the body of our Lord was incapable of corruption, whereas Theodosius maintained that though it did not actually see corruption, yet that it was capable of it. The scenes which followed are strongly indicative of the state of the church in the sixth century. On the death of a patriarch of Alexandria, the custom was for his successor to perform the funeral rites over his remains, during which he placed the hand of the dead man upon his own head, and after burying him, assumed the 'pall of St. Mark,' and so mounted the throne. As Theodosius was the court candidate, he succeeded in so far getting the start as to perform some of 


\section{arisen for the disturbing of the church : he even sent me, though but of small account, three epi- stles upon this subject.}

these ceremonies, but before the funeral was over, and the throne mounted, the monks and populace who sided with Gaianus drove him away. Gaianus now filled the see for three months, until Justinian sent the famous eunuch Narses to reinstate Theodosius ; and when the citizens drove him out of the town by force, the very women throwing missiles from the roofs of the houses, Narses set fire to the city, and having burnt down most of it, obliged them in this manner to receive their bishop. The arguments of Severus of Antioch against Julian of Halicarnassus, the chief defender of the tenets of Gaianus and his party, (and which are still extant in MS. in the British Museum,) seem to have gradually brought over the better educated portion of the inhabitants of Alexandria to Theodosius' side, but as the mob there continued its resistance, he was at length deprived of his see by Justinian, and retired to Constantinople, where, as I have mentioned, he was supported by Theodora's influence, and still recognised by the Monophysites as the true patriarch of Alexandria. Cf. Le Quien, Oriens Chr. ii. 430.

The reason alleged by Renaudot for his being deprived of his see is, that really his restoration was brought about by Theodora, and Justinian vexed at seeing so great power in the hands of a man opposed to his theological tenets, wrote to him and required him to receive Leo's letter, and use his exertions to bring about its general acceptance in his diocese ; in which case he promised to make him the temporal as well as spiritual governor of Egypt, and subject all the bishops of Africa to his authority, whereas should he refuse, he was immediately to quit his see. On receiving this letter, Theodosius told the prefect and the messengers, that the devil once took our Lord into a mountain and shewed him the kingdoms of the world and its glory, and said, "All this will I give thee, if thou wilt worship me.' And so now the emperor offered him what would be the ruin of his soul, if it led him to desert Christ his King. Then raising his voice, he said in 
As for Peter, whom others had set up as bishop IV. I6. of Alexandria when the see was already occupied, to be but as a picture painted upon a wall, while they managed every thing at their own will, not content with his illegal and disorderly election, and with having induced him to ordain men without examination, young and old alike, until he had made a string ${ }^{\mathrm{n}}$ of seventy bishops, and other clergy in proportion, they now led him on to another violent act, and prevailed

the presence of the multitude, 'I anathematize Leo's letter, and the council of Chalcedon; and all who approve of its articles of faith, be they accursed now and for ever.' Then turning to the prefect, he continued, "The emperor has power over my body, but not over my soul. Jesus Christ the true emperor has power over both. I am ready, therefore, to follow the example of my predecessors, Athanasius and Cyril and Dioscorus and Timothy, and suffer as they have done for the faith.' $\mathrm{He}$ then went out, exhorting all who loved God to follow him ; for naked he had left his mother's womb, and naked he must return to it : and that whosoever lost his life for the faith's sake, would save it. At night he was taken into custody, and sent into the Thebsis, where he exhorted the monks to constancy; but the emperor, fearing lest his example should encourage the people to remain firm in their creed, commanded him to come to Constantinople. There his modesty and humility won for him the emperor's respect, who treated him kindly, and tried to win him over to his views; but finding all his efforts unsuccessful, he finally banished him to a place a few miles from the city. Ren. Pat. Alex. I39.

n The word $\left.\right|_{\Lambda} \circ$, used in the original, signifies, I. ' $a$ bow ;' 2. 'chaff.' As, however, I find that the root has the meaning of ' collegit,' cf. Ges. Thes. sub קשטש, I have translated it in this sense. 
upon him to venture to pronounce the formal deposition of Paul of Antioch, in violation of the order and canons of the church; nor did the fact of his having no legal rights himself restrain him from this piece of audacity. And for the purpose of stirring up opposition and hatred, he drew up a paper full of false accusations against Paul and others, and was guilty of such acts of tyranny and pride, that he can be compared only to a drunken man, who wanders about without sense after his vomit; nor had he any will of his own, but acted as they who appointed him led him on. And these missives he sent every where, and committed other acts, which became the fruitful source of schisms, and widened the breach and dissension already existing between the churches of Syria and Egypt.

IV. 17. To some of these acts the blessed Jacob was prevailed upon to give his consent ; for being, as we have said above, a simple man, he was influenced by the violent persons who surrounded him, and whose object was to find an opportunity of showing the hatred, which by the instigation of the enemy of man, they entertained against Paul. They now, therefore, prevailed upon the old man to visit Alexandria, persuading him that he would thus establish unity between Alexandria and Syria, though they were themselves well aware of the old grudge and unappeasable enmity which had long existed at Alexandria against Paul, and of which the sole root was envy. 'They found means, therefore, of in- 
ducing the unsuspecting old man to visit Alexandria, telling him he could do so without its being generally known; but many, when they heard what he was about to do, wrote to him and protested, that he ought not inconsiderately to go there alone, lest he should be prevailed upon by their wiles to take part in their hatred, and so fresh schisms and disputes be occasioned between Egypt and Syria, and the evil already existing be increased and strengthened. But those about him were deaf to persuasion, and took him to Alexandria, where he fell among ' a barbarous ${ }^{\circ}$ people,' as Scripture says; and having led him Psalm there, they next induced him by trickery to submit to communion with Peter, though he had himself reproached him both verbally and in writing, and called him a new Gaianus risen up for the confusion of the church of God. And further they prevailed upon him to draw up a paper, professing to be articles of union, and offerit to the very person whom he had himself blamed and reproached, and said that he was nothing better than an adulterer, who had seized

o This is now the third time that John has applied to the Alexandrians the remarkable epithet ho>>, taken from Psalm cxiv. I, the only other place where it occurs. Bar Bahlul explains the verb as Egyptiace locutus est : but plainly John intends by it 'savage,' 'barbarous.' The people of Alexandria do not seem to have borne a very good character in ancient times, if we may judge from Dio Cassius, who calls them (lib. 4. 24),

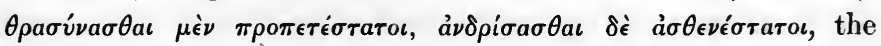
greatest braggarts, and the most utter cowards in the world. 
upon another's wife, in having been consecrated to a see, which another orthodox bishop already filled. But in thus acting, their real motive was hatred to Paul, whom they hoped to find an opportunity of condemning and deposing; and thus they closed their eyes to all other considerations, and joined the very Peter whom they had reviled as a new Gaianus, and, as the saying is, trampled all propriety under foot, and counted as nothing the violation of the canons which they had themselves previously laid to Peter's charge ; assenting and setting their seal to all his illegal acts, and, above all, to his deposition of Paul, patriarch of Antioch, which audaciously and tyrannically, and in violation of all canonical rules, had been pronounced by Peter and his party, in Paul's absence, before the arrival there of Jacob. For when they first heard of it, this act had delighted them and gratified their feelings of enmity; for they hoped that the yoke of their patriarch Paul was taken from off their neck, and they, therefore, wrote and gave their assent thereto. The old man Jacob, however, persuaded them that the deposition should not be accompanied by any act of excommunication.

IV. 18 . On the completion of this turbulent business at Alexandria, which proved a fruitful source of ruin and disturbance and schism and quarrel to the whole church of Syria, Peter asked the blessed Jacob and his companions, on their departure, after having approved and confirmed every thing he had done, to allow three of his bishops 
to accompany them back to Syria to give their testimony and confirmation to the disorder they had wrought. They travelled, therefore, in company; and all Syria, so to speak, was startled and astonished at their coming. And when they began to tell the purport of what they had done, and the deposition of Paul in violation of canonical law, a great division and schism and offence was the immediate consequence throughout the whole church of the believers in every part of Syria; for many assented to what had been done by the old man Jacob at Alexandria, some for his own sake, because for a long time they had looked up to him, and others, because they hoped that a firm and lasting union would so be made with Alexandria: but the rest at once dissented and disapproved and rejected all that had been done there, blaming and severely censuring Jacob and his party; for at first he had himself blamed Peter's appointment, and reproached both him and those who consecrated him, and called him a new Gaianus whom the Alexandrians had set up for the disturbing of the church: and said that his appointment was contrary to the canons, and invalid, and his priesthood nought, and that he was an adulterer; and then, after all this, he had gone and assented and submitted to the man whom he had rejected and reproached, and had communicated with him; nor so only, but had even presented to him a petition: for the three bishops who accompanied him back had 
brought it with them, and showed it privately to many, saying, 'See, here is the petition which father Jacob made and presented to pope Peter.' And this they did in secret, as neither he nor his companions considered that it was a petition which they had drawn up, but articles of union; and were it not for the length of the narrative, we would have inserted it here in its place entire.

IV. I9. Unfortunately the schism was confined to no narrow limits, but spread from Syria into Cilicia, Isauria, Asia, Cappadocia, and Armenia; and especially to the capital, so that in this the 887th year of Alexander (A.D. 576), grief upon grief, and blow upon blow fell upon the persecuted and lacerated church of the believers every where, by reason of the division, and quarrels, and schisms, and wrongs, and evil deeds which sprang up and multiplied between Jacob and Paul, and spread like an ulcer cruelly, and without fear of God. For the bishops and clergy and monasteries, great and small, joined some one side and some the other, as also did the people of the churches, both in towns and villages, and in the country: and each faction eagerly set itself to injure, and ruin, and revile, and speak evil of the other, with barbarous and unmitigated violence, seeking the other's wrong, and slandering them, and dividing the people, and producing schism in the churches, and tearing the congregations to pieces, till each one abominated his neighbour, and rent himself from him, 
and endeavoured to enlarge his own party, doing his utmost to produce division, and make others stumble, and cause schisms, and bring men over to his own views. And thus both sides were filled and exasperated with the spirit of opposition, in contempt of order and judgment, and the fear of God: to which had they not been strangers, they would have repented of their evil doings, and ceased from thus creating schism and disturbance in His church. But this course of murderous hatred and rancour, and reproach and mutual revilings was stirred up in them by one who asked 'that he might sift them as Lu. xxii. wheat,' by tempting them to deride and reproach ${ }^{3}$ r. one another. For even of heathens and Jews and heretics, no one, however fierce and savage, would venture to speak so reproachfully as the believers did of one another; at the very time when in matters of faith there was no difference or dispute between them.

Upon the breaking out of this fierce and cruel IV. 20. and disorderly schism between Jacob and Paul, and not between them only, but generally throughout all Syria, and the neighbouring countries, where every one took either one side or the other, some approving of and receiving all that had been done by Jacob in Alexandria, while others sided with Paul, and rejected Jacob's proceedings, as being entirely contrary to canonical order; to which view the chief monasteries principally inclined: when this savage and violent state of things everywhere prevailed, 
Paul constantly sent to Jacob, by the hands of numerous messengers, saying, "Why is there all this disturbance in the church of God? Let us hold a conference with one another, and examine canonically and legally the matters in dispute between us, and if I am guilty according to the canons, instead of one sentence and one canon, I am ready to submit to three; but if, on the contrary, the fault rests with you, even so for your sake I will submit to it.' But those who were about the simple old man Jacob, would not let him give way, and consent to see and converse with him; for they knew that they could not stand before him, and knew too that at his first word he would convict them as they deserved. Jacob therefore said, 'I have come to terms with and received the Alexandrians, and drawn up writings of agreement with them; and from them I cannot turn away, and without their consent neither shall he see me nor I him.'

IV. 21. Equally in vain was the intercession of Mondir, son of Harith, king of the Arabs, who was both a believer, and an active and zealous man, and who spent much time in urging and supplicating both sides to cease from their wrath and contest, and hold a conference with one another, and talk the matter over, and make peace. But the Jacobites would not consent, though Paul besought both Mondir himself and others, that a full examination and inquiry might be made into those things which had been stirred up by Satan between them. And inasmuch as for a 
long time, from the days of Harith his father, they had regarded Jacob as a great man, and subsequently, at a later time, had similarly respected Paul; and now the two had come to so fierce a difference and quarrel, and Jacob's party would not be appeased, the discussion spread also among the Arab tribes, and to many of them also the matter proved a stumblingblock; for some went after Paul, while others took the side of Jacob.

The news of this dissension and disturbance IV. 22. caused Longinus and his companions, and with them Theodore, whom they had made patriarch, to proceed from Egypt to the countries of the East, and especially to Syria, where they joined themselves to the adherents of Paul, with the view of entering into a judicial examination of the matter with the partizans of Jacob, and if possible to put an end to the quarrel, and the continually increasing evils to which the dispute led. Theodore therefore remained quietly in the city of Tyre, but Longinus went to Hirah, the capital, founded by Gabala, son of Harith, to find Mondir, the son of Harith; and after he had conversed with him, and told him exactly the whole truth, the king was the more anxious to get them together, and reconcile them; but the partizans of Jacob utterly rejected his mediation. Finally, however, a large number of Jacob's party and himself assembled in the monastery of Mar Ananias $p$ in the desert: and one of them, a

p Asseman, in his account of the Monophysites, mentions a 
bishop, named John, belonging to the same monastery, was sent, with a fraudulent purpose, to Longinus and his companions, saying, 'Inasmuch as the old man, my lord Jacob, has come hither, and wishes to converse with you, come to him quickly: for there will be present only us three, myself, and you, and Jacob, and we will talk the matter over, and put an end to the quarrel, and bring this turbulent state of things to an end.' And upon the receipt of a letter to this effect, Longinus readily arose, and started, accompanied by the rest of his party, and arrived there. But no sooner had they come, than they conducted him and his company into a place where there was sitting no small crowd of monks, and laymen, and jurists, and lawyers. And when Longinus saw the partizans of Peter q, he said to John, who had come to invite him, "What fraud is this that thou hast done me, and hast written unto me falsely, saying, that the old man was here alone, and that I should come that we three might confer together? where is the old man? and what is this crowd?' And on

monastery of Mar Ananias in Mesopotamia, famous as being the residence of their patriarchs, from A.D. I 166 to the present day. But from his description, it is apparently a different place from the monastery in the desert mentioned here.

9 The word in the original, $f_{i} \delta 9$, is very uncertain : a point over the initial letter seems to requite the vowel to be $a$,

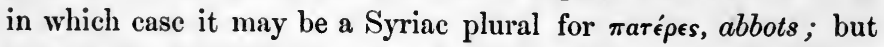
I am rather inclined to read it $\pi \epsilon \tau$ eiou, and refer it to the three Alexandrian bishops, sent to represent pope Peter. 
his thus speaking, one of the monks produced a written indictment against him, and said, 'Take and read this, and give in an answer thereto.' But he replied, 'I have been invited hither by fraud and falsehood, and I will not read it, nor give an answer to any man.' And upon his looking round for a means of escape, they laid hands upon him, and seized him, saying, "You will not get out hence until you have read it: and if you will not read it, we will read it to you, and listen.' But when they began to read, he put his fingers into his ears, that he might not hear. Whereupon they began to pull him this way and that, and he cried out, 'Woe, woe, what have I doner? why am I to be treacherously murdered?' And now a strife arose, and the quarrel grew louder, and a scene of disorderly violence ensued, and murder was at the very point of being committed, until he managed, still crying 'Woe!' to extricate himself from among them, and get out, and save himself from their hands, and flee away. Jacob himself he never even saw. And many such acts as these were committed everywhere by the evident instigation of devils.......

The rest of the chapter, and the next eight, are lost; but it is evident that they contained the recital of similar acts of unbridled temper

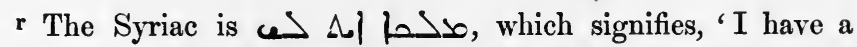
king ;' but as this is nonsense, I imagine the right reading to be ce) 4.1 is os. 
and firaud and violence, from the few lines of the thirtieth still preserved; in which we find our historian lamenting, that 'deeds were wrought on both sides by the two factions, into which the believers-so unworthy of the name--were rent, so insensate and unrestrained, that Satan and his herds of demons alone could rejoice in them, as involving the ruin of the church, while for all reflecting men they were a source of lamentation, and bitter sorrow, and groans.'

That these words are not stronger than the facts warrant, we learn from what he next narIV. 3 r. rates; for he tells us, that the principal and most famous monasteries, both in the south and east, were split and sundered into the two opposing parties of Paulites and Jacobites, and that they were so exasperated against one another as to come to blows and fighting, and the mischief wrought was incalculable, and often ended in murders. Finally, the civil powers interfered, and many arrests were made, and the monks dragged in chains and fetters to Antioch the Great, and cast into prison : and so the honoured dress they wore, but which they had not honourably kept, became an object of contempt and ridicule to heathens and Jews and heretics, when they saw them brought before the courts of justice, manacled and fettered, and charged with murder; being men of venerable aspect, aged monks, with beards so long as to reach to the hems of their garments, but now with collars round their necks, and standing before the judges to 
answer for the crime of bloodshed. Who would not tremble and lament and wail over deeds so horrible? Who would not mourn as the hyæna, and lament as the jackal, over salt which had not only lost its savour, but itself become foul and rotten, and therefore was cast out and trodden under foot of men? And in other monasteries the monks divided into two parties, of which the one continued in their old home, while the other abandoned it, and went away and found some other place to dwell in, to which they gave the name of the monastery they had left; but even so each entertained against the other a feeling of deadly hostility unchecked by any thought of moderation and restraint.

Nor did the abbots shew greater moderation IV. $3^{2}$. than the inferior monks; for after numerous meetings held in various places, they at length assembled in a great congress, and after long debate, and preparation for opposing the adherents of Paul, they decided upon appointing. three of their most active partisans, men ready for any contest, to go as a deputation to the old man Jacob, and those who were with him, to rouse and incite and stir them up by a letter which they addressed to them, and which we are prevented from inserting only by its length, but its purport was to bid them stand up zealously, and make a patriarch for them in Paul's stead; and further they asked them, what they intended to do with respect to Paul's ordinations, and as to the Tritheites, and so on. And when 
the letter was brought to the old man, he gave orders for a meeting to be held in the monastery of Mar Ananias; but when they began to talk the matter over, several of the bishops would not consent to create a patriarch while Paul was alive, and not canonically condemned ; ' for how,' said they, 'can we trifle like children who have not yet arrived at discretion, and make another patriarch while there is one still living, and expose ourselves canonically to punishment?' And as they could not agree, the meeting separated without accomplishing any thing.

IV. 33. Soon after they had thus been prevented from making a patriarch, the blessed Jacob suddenly determined upon going down forthwith to Alexandria ; and accordingly set out thither, accompanied by several bishops and other attendants, to the number of eight. And among the many opinions entertained concerning his journey, the most prevalent was, that he intended, in conjunction with Damianus ${ }^{s}$, the patriarch there,

s The Arabic authorities, quoted by Renaudot, Pat. Alex. 144, agree in assigning two years to Peter in the see of Alexandria; but it is evident from our author, that the Canon Chronologicus is right, which fixes his death in the tenth month after his election. Damianus, the next patriarch, had previously been Peter's syncellus, having been appointed to this office from the great reputation he had acquired as an ascetic in a monastery on mount Thabor, where he devoted his time to sermon writing, and to disputations with heretics. I may mention, that the Chronology of Renaudot is hopelessly confused in this part of his work, from his not being aware that many years elapsed between the death of Theodosius and the election of Peter. 
to create a new patriarch for Syria: while others affirmed, that his purpose was to come to terms with the followers of Paul: but as he kept his intentions secret from every body, it will never be certainly known what his real views were. But from the eyes of God nothing is hid, and ever does He watch over the good of the creatures of His hands. When therefore they had commenced their journey, and had reached the great monastery of Cassianus on the border's of Egypt, there first of all, as was said, immediately one of the bishops who accompanied him, and who was abbot of Cartamin ${ }^{t}$, died. And the old man arose, and celebrated the communion over him to his memory. Almost immediately afterwards, Sergius his own syncellus, and who was also a bishop, fell sick and died; and then the old man also fell sick, and lingered for three days, and died; and finally the deacon who waited upon him. All these died unexpectedly one after another within a period of twelve days; and men wondered greatly, and interpreted it in various ways, and their thoughts were troubled. And when the news reached Alexandria, Damianus and the rest of the clergy hastened thither, but arrived after the old man's death, and wanted to carry away his remains with them, but the

t Cartamin was a very ancient monastery of the Monophysites, situated near Marde, in Mesopotamia. An account of it is given by Asseman, in his Essay on the Monophysites, prefixed to the second volume of his Bibliotheca Orientalis. 
inhabitants of the monastery would not give their consent. And astonishment seized them because of all these things, and wonder that the blessed Jacob and his company should so suddenly be snatched away; and many concluded in themselves that possibly he was about to do something strange, and likely to increase the troubles of the church; or that he was even purposing perhaps to make a patriarch; and so God took him to Himself, that the soul of the pious old man might not suffer loss.

IV. 34. As the death of the blessed Jacob and his company was so sudden and remarkable, it naturally led to various rumours, but there was one especially most wicked as well as unfounded, invented by men who have no fear of the account which hereafter they will have to give, nor care for their own souls. For counting as nothing the injury of their own souls, they were not ashamed to say, that some of Paul's party by his command lay in wait for father Jacob on the way, and beat him with staves, and stoned him and his companions, and so seriously injured him that he was just able to creep into Egypt to die there. But this story is not merely false, but very wicked ; for to increase their own condemnation, and multiply the causes of offence already existing, they eagerly spread this rumour abroad every where, that they might terrify others, and cause them to stumble, and defile the consciences of believers, that others might be offended and their own party increased. As for the injury 
and ruin which their own souls suffered by spreading abroad such murderous calumnies, it gave them no pain or solicitude, because plainly they were destitute of all fear of God.

Various attempts meanwhile were made from IV. 35 . time to time to reconcile the Paulites and Jacobites; and especially the three ambassadors, who were sent in the year 888 (A. D. 577) to confer with the Persians about reestablishing peace on the borders, did their utmost in Paul's behalf. Their names were Theodore the patrician, and the consuls John and Peter, of whom we have read before, and who both were inclined to side rather with Paul; and so greatly did they interest themselves in his behalf, that they thought far less of the political objects for which they had been sent, than of assembling meetings every day, and addressing them in his defence. And even father Jacob went unto them, attended by numerous friends, and the debate between them was so long that the particulars of it would exceed the bounds we are obliged to set to our narration. But neither side could persuade the other, and they parted with feelings of mutual annoyance, and withdrew from one another. And in every city which the ambassadors visited they made the same attempt; but as the people in the East along the banks of the Euphrates as far as the dominions of the Persians, for the most part, held rather with the blessed Jacob than with Paul, they could not be prevailed upon to give way; and so they returned hither 
to the capital much offended, and reviling all the orientals.

IV. 36. The course taken by the Arabs of the desert was the only one marked by any degree of moderation; for originally, before the schism broke out, the tribes there acknowledged the authority of the blessed Jacob; but when, during the lifetime of the old king Harith, Paul fled thither, and remained in concealment among them, they were greatly edified also by his presence, because of his moderation and gravity and learning. And especially this was still more the case after the death of Harith, when both parties often met there, and received one another in a friendly manner: so that, in short, at Hirah all the Arabs equally respected Paul and Jacob. But when afterwards Satan put enmity between them, the Arabs were all grieved, and especially their king Mondir and his brethren and children. And they besought the old man Jacob to be reconciled and unite again one with the other; but he would not consent either to receive Paul, or join in union with him, making the Alexandrians his pretext; 'For if,' said he, 'they will not receive him, neither will I.' And at this the Arabs were all offended and annoyed; and when Paul went there, they received him, and took the communion at his hands; and when Jacob went there, they did the same, until he decreed that they were not to take the communion from Paul. And so they all continued offended and vexed and troubled until the death of the old man 
Jacob: and after his death many still adhered to his party, but others went over to the side of Paul; and others received both alike. But all, without exception, were vexed and saddened at this strange schism and quarrel which had arisen between them, and especially king Mondir; for constantly he besought the two parties to make peace with one another; but the envy and hatred of Satan, and the evil counsellors on both sides who did his will, prevented there being any respite or reconciliation until the day of Jacob's death. And so, when the old man was in the thick of the quarrel, while busied in his journey to Alexandria, God Who knows all things, and who had forethought for his real good, commanded that his end should overtake him on the way.

Besides the orthodox patriarch Damianus, IV. 37 . Peter's successor at Alexandria, there was also the synodite patriarch, John ", and repeated complaints being made by him in letters to Constantinople, orders came for the arrest of many of the orthodox clergy, with directions to send them to the capital. And on their arrival there in the month of May, in the year 890 (A. D. 579), the patriarch Eutychius refused to see them, and sent them a pompous message, saying, 'Inasmuch as on the former occasion, when ye were brought hither, I let you go upon your promising

* " Joln, the synodite, or, as we should say, the catholic patriarch of Alexandria, occupied the throne about eleven years from A. D. 568 to 579 . 
to receive the communion from me, come and do so now, and then ye shall have an audience with me, and see me.' And on hearing this message, they sent in answer, 'We never promised to communicate with you, except upon the condition of your rejecting the council of Chalcedon.' Upon which he became angry, and had them sent away, and separated from one another, and imprisoned in various monasteries.

IV. $3^{8}$. One of these clergy was the Theodosius, archpresbyter and chancellor of the church of Alexandria, whose letter to Longinus, requesting him to consecrate for them a patriarch, had led to such disastrous results. He now was imprisoned in a monastery at the Natron Lakes, but soon after fell ill, and died in a good old age: and great grief was felt at his loss by all the Alexandrians, and especially by the imprisoned clergy. His death took place after their first summons to a discussion with the patriarch Eutychius; on which occasion they had said, that unless either the king or senate were present as moderators, they would not debate. Long negotiations followed, but finally they were sent back to the monasteries in which they had been imprisoned. And when they were now expecting a second summons to Constantinople to a discussion, their chief fell ill, as I have mentioned, and died, while they were still in prison and carefully watched.

IV. 39. At length, however, there appeared to be some chance of reconciliation between the followers of Paul and Jacob by means of the good offices of 
Mondir, the son of Harith, king of the Arabs. For when a very furnace of Babylon seemed to be blazing and burning more hotly than ever between the two factions, kindled on insufficient reasons and groundless conjectures by the officiousness of men, who, to gratify their envy and an old grudge, envenomed the simple and laborious soul of the old man Jacob against Paul; and the two parties were mutually reviling and reproaching one another, beyond all bounds and rules of propriety, without restraint, and, unbridled by the fear of God, Mondir made a journey from Arabia to the capital, and there laboured zealously to bring about a peace. For though the will of God was fulfilled in the old man Jacob, and he rested from this painful and troubled life, and departed from the world, yet the same, or even more, grievous quarrels continued, and mutual anathemas, and their minds were everywhere savagely excited in every region and district and province alike, in the East and the West, until, in the words of Scripture, 'they had Ps. lxxix. become a reproach to their neighbours, a scorn ${ }^{4}$. and derision to them that were round about them.' But the illustrious Mondir, who had been honoured with the title of Patrician, on visiting the capital by invitation, and being magnificently received there by the king, set himself manfully and piously to abate all these evils, which he saw mutually practised by men who were members of the same faith and the same communion. He assembled therefore both sides, and scolded and 
admonished and reproached them for all the evils and schisms and quarrels which had sprung up between them: and advised them to cease from these strifes, and be at peace with one another; and the more so, because they were all members of the same faith. And advice to this same effect he had long ago given to Paul and Jacob in person, and had prayed them to live in peace and love one with another.

This visit of the illustrious Mondir to the capital took place in the year 891 (A. D. 580), on the eighth day of February; and he was received with great pomp, and endless honours conferred upon him by the merciful king Tiberius, who made him large presents and royal gifts, and did for him all that he desired, and gave him everything he asked, even bestowing military titles on the two sons, whom he had with him, and giving him leave to wear a royal crown.

IV. 40. The meeting, which, with Tiberius' consent, was convened by the illustrious Mondir, was held on the second day of March in the above-mentioned year, and attended by the chief men of note on both sides, and also by the Alexandrian clergy; and his advice was, that they should cease from their quarrels, and put an end to and trample out the evils stirred up by Satan among them. And upon this, a debate took place too long for insertion here, and much was said, not only by the followers of Jacob and Paul, but also by the Alexandrians, who appeared as a third party, and finally by our own unworthy self : and inasmuch 
as there were many persons of discernment on all sides, who deeply regretted the violent deeds wrought by turbulent men of all three parties alike, and rejoiced at the prospect of peace, and at an end being put to so many evils, they all consented, and unanimously promised, that they would unite again, and it was settled that they should enter into a compromise, and that all the points of difference which Satan had stirred up between them should be examined into, and done away. And when every one had agreed to this, a formal deed of union was drawn up, by which all schisms and quarrels were to cease, and the archbishops, and bishops, and clergy and monks of all the monasteries, and the laity, who were at variance, were to receive one another, and all with one accord consent to be at peace. And hereupon prayers for union were offered up by the priests on both sides, and also by the Alexandrians, and the reconciliation was complete; and all praised God for driving away the evil one, and putting an end to the wicked acts done at his' instigation among them: and each and all promised that they would severally use their strenuous exertions to bring those of their party who were absent in the body to assent to this pacification. There were found, however, seditious and turbulent men, full of the canker of iniquity, who complained, and were displeased at the peace which had been made: and because the chiefs and notables alone had taken part in the conference with king Mondir, and the com- 
mon people had not been summoned to the meeting, chiefly on this ground they set themselves against it, and wished every thing that had been done annulled. They held meetings, therefore, and made disturbances, and wrote and agitated both in Syria and Alexandria, and prevailed on many to join their party, and not to submit to or accept any thing that had been done, to the great delight of Satan, and all his hosts of devils. The meeting however at the capital separated quietly and with joy, and all thankfully accepted the grace of God, and the services of the illustrious Mondir.

Our historian next relates an attempt of Damianus to consecrate a patriarch of Antioch, which must have taken place at least a year previously to the meeting just described as having been held in A. D. 580. The deacon Peter did not survive his consecration many months, so that the number of bishops created by him would be incredible were it not that at that time the ordinary officers of a patriarch's household were frequently members of the episcopate, as were also many of the abbots and leading monks, as well as the clergy of the towns; and as none probably had been consecrated during the ten years which intervened after the death of Theodosius, Peter had at least a specious pretext for thus increasing IV. 4I. the power of his party. At his death, Damianus, a Syrian, was elected, and equally in John's eyes was a usurper, appointed contrary to all church laws, and moreover he describes him as an illite- 
rate and unwise man. Of this he gave a proof in conceiving the vain and foolish idea of journeying to Syria, and appointing, in violation of the injunctions of the canons, a patriarch of Antioch in the place of Paul while he was yet alive; in imitation, as it seemed, of his own appointment and that of his predecessor, after another had been nominated to the see, even Theodore, and had written his synodical letters to Alexandria; whereupon the Alexandrians became furious, and savagely and barbarously were stirred up in hot wrath, and consecrated Peter, a deacon, and a simple and unlearned man, whose name they used for their own purposes as they chose. And so there were two patriarchs at one time upon the same throne, and Peter therefore and Damianus his successor were often spoken of as adulterers, who had entered in and defiled another man's wife. As though his purpose then had been to hide his own shame in occupying a throne, of which Theodore, who was consecrated even before Peter, was the rightful owner, Damianus formed the plan of appointing another patriarch for Syria while Paul was still alive, that there might be found among them a parallel case to that of which the shame rested upon himself. On his arrival therefore he summoned the Syrian bishops, and urged them to join him in appointing a patriarch of Antioch: but several of them, out of regard to the canons, declined, saying, ' Until Paul has been summoned, and tried and convicted of the offence laid to his charge, and 
condemned and canonically deposed, we cannot consent to appoint another in addition to him. Nor must he be only canonically condemned, but also excommunicated.' . But others agreed with Damianus, and consented to join in making another patriarch. They found, however, great difficulty in prevailing upon any one to allow himself to be appointed: for the first and second to whom they proposed it said, 'As long as the man is alive, and has not been cited and tried according to the canons, and condemned and deposed, I for my part cannot consent to be set in his place; for possibly the end would be, that I should myself be deposed.' At length, however, they found a silly man like themselves, named Severus; and Damianus, in company with two other bishops, took him with him, and entered Antioch by night; and sent secretly to the sexton of the church of Cassian, and promised to give him eighteen darics if he would leave the church open, that they might enter at night, and consecrate Severus there. And when the sexton had accepted their offer, and promised them his help, and they now felt confident of success, and every thing was ready, the news got abroad that they were about to consecrate some one or other by stratagem: and information being given to the patriarch $^{x}$ of the city, he immediately sent orders

$x$ By the patriarch is probably meant not Paul, but the synodite patriarch, as Paul would not have had power sufficient for the purpose. In the next chapter it is certainly the synodite patriarch who is described in similar terms. 
for their arrest. They surrounded the house therefore, in which they were, and having effected an entrance, seized upon three monks, but Damianus and his bishops and some others managed to descend into the latrina, and thence scrambled out by a window at the back, and so made good their escape, but with both their persons and their dress all covered with filth and ordure. The names of those who escaped in this distressing manner were Damianus himself, and Sergius the single-browed $y$, and George Sarcabinus, and the bishops who were to have joined in the consecration, and Severus, the intended patriarch: and they were more ashamed at having had to encounter this uncleanness than at the failure of their deeplaid plans. As for the monks who were arrested, they brought them to the patriarch, and he had them hung up and bitterly tortured, until they acknowledged every thing they had been about to do. Having confessed therefore about Damianus, and his party, orders were sent everywhere for their arrest, but they succeeded in making their escape. They confessed also about the sexton, and he was brought, and acknowledged his guilt, and was tortured even worse than the monks were, and his goods pillaged. Damianus, on his. escape, made his way in disguise to Constantinople, just before the meeting was held for the

" He is called 'Sergius Anophitor, that is, Ixo:-', one whose eyebrows meet: whether Anophitor is the corruption of some

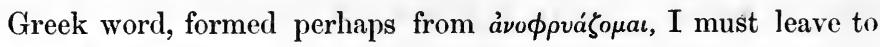
others to settle. 
establishment of unity; and by the zealous services of certain who were anxious for peace, he was introduced by night to the illustrious Mondir, and they conversed with one another, and he promised that he would do his best to bring about a reconciliation, and assent to it himself. And after holding interviews with a few persons, he withdrew secretly, and arrived at Alexandria: it was said, however, that he had made bishops even at the capital.

IV. 42. The Alexandrian clergy who had been present at this meeting were at Constantinople under arrest, together with many laymen of note, and Mondir now offered his intercessions in their behalf with the merciful king Tiberius, and he let them go; and not content with this, Mondir made them handsome presents because they had consented to a reconciliation, and they left with joy, and went on board, and returned to their city. And subsequently the illustrious Mondir begged that he might himself be permitted to leave, having first interceded with Tiberius also for the peace of the church, and begged that all persecution of Christians might cease. And he further promised on oath, that if Tiberius would cease from all military proceedings, he would immediately make peace. And upon this promise Tiberius dismissed him with great honours, and kingly presents of gold and silver, and magnificent dresses, and saddles, and bridles of gold, and armour. And besides all this, he also gave - him a royal crown, the right of wearing which 
had never hitherto been conceded to any of the chiefs of the Arabs, but only leave to put on their heads a simple circlet. And thus then he was sent away, and departed with great pomp and joyfulness. And on his arrival at Antioch, he was similarly received there; and supported by the express wishes of the king, and his promises and oaths for the union of the church; and by his orders that the persecution should cease, he gave notice thereof to the patriarch and other officers of the city: and the patriarch immediately gave orders, and letters were written to the provinces, enjoining that no one should venture upon persecuting others; for that the king had commanded and wished peace to be made. And so for a short time the persecution was stilled. But when news of this reached the Dyophysites at the capital, they were very angry with Mondir, and went and accused him harshly before the king, but he would not listen to them.

Now while Mondir was on his road, those hostile Arab tribes who were subject to the Persians, having imagined that his detention at the capital would be indefinitely prolonged, gathered themselves together, and supposing him to be far away, marched in company with the Persians into his territories to attack his sons and brothers, hoping to fall upon them and slay and take them captive. But at the very moment when they were drawn up in hostile array, Mondir suddenly arrived, and at once, without their expecting it, he gave orders for the attack, and 
fell upon them and slew them until they were consumed, and very few escaped from his sword. And so his return was a joyful one, and he brought with him great spoil, and was extolled by every body, and his name magnificently praised.

IV. 43. The pacification, however, which he had wrought in the church was but of short duration: for no sooner had the Syrian, Damianus, returned to his see at Alexandria, than, being blamed for making peace with Paul, like one more desirous of pleasing men than God, and indifferent to the peace of the church, he violated his word and proved false to the promises he had made to the illustrious Mondir, and to the rest of the believers of both parties who had interceded with him, and turned round and opposed Paul, and wrote anathemas against him, and reproaches and contumelies of the harshest kind. And not content with this, he even penned a circular letter to the same effect, and sent it to Syria, and to all other places both in his diocese and elsewhere. And these letters were chiefly given to those men of turbulent and savage temper, who are Satan's yokefellows, and labourers with him, and who instead of gathering with Christ scatter abroad. And being thus encouraged, they stirred up schisms everywhere and disputes and quarrels and all the evils in which the devil delights, more vehemently even than before. And in thus acting, Damianus was guilty of deeds worthy of himself, or even per- 
haps one may not unfitly say, of Satan. And the clergy also who were present at the meeting held in the capital for the purpose of bringing about a reconciliation, imitated his example in lying against the Holy Ghost, and proved false to their word, though they had been set at liberty and escaped from their troubles by the earnest intercession of Mondir in their behalf. And he had thus exerted himself because in his presence, and before a numerous assembly, they had promised to be reconciled and join in union, and had signed their names to a paper to that effect: and thereby had obtained their freedom, and escaped from confinement and from prison; and yet afterwards they turned round, and were ' faithless like their fathers,' that is, like their fa- Psalm ther Damianus, who was as bad as they were, lxxviii. 8 . and they equally bad with him. When therefore king Mondir returned from battle with his enemies, and learnt their perfidy, and how they had changed from truth unto endless falsehood, he was very sorrowful : and surprised, moreover, and astonished, especially at Damianus' circular letters, which approached as near as possible to utter wickedness. Nor did he even decline the trouble of writing to each one of them by name, to admonish and reprove them for their falsehood against God and himself and the whole church. And they, from shame and mortification, would not receive his letters, nor would they write an answer. And he thereby was greatly offended, 
because these letters lit up a flaming furnace of anger throughout the church of the believers, and multiplied the strife already existing, and made their quarrels blaze up more hotly than ever without restraint or fear of God's just judgment.

IV. 44. For immediately that these letters were received in the east, they stirred men up to the irregular proceeding of creating a second patriarch, as far as the name went, of Antioch, while the first had never been publicly condemned as the canons direct; and this gave the mockers an opportunity of saying in sport and derision, ' $\mathbf{A}$ second patriarch, we suppose, was wanted to be nominated for Antioch, because there are three $^{z}$ at Alexandria, to say nothing of him of the synodites, and they cannot make game of one another.' So disorderly and confused was all that was done among the believers, because their incessant quarrels turned every thing upside down.

IV. 45. They even endeavoured to draw John himself into the quarrel, by writing to him at the capital, and requesting him to communicate with their

z By referring to page 77, it will be seen that besides John, the catholic patriarch of Alexandria, and Damianus, the Monophysite, there was also one created by the followers of Gaianus, or Julianists, as they were indifferently called, because of the services of Julianus of Halicarnassus in defending their tenet of the incorruptibility of our Lord's body. His name was Dorotheus : and Le Quien incorrectly supposes that the Theodosians concurred in his election. Oriens Christ. ii. 438 . 
new patriarch. For in the year $892^{\text {a }}$ (A. D. 581), the bishops and abbots and clergy of the blessed Jacob, after his death, formed the plan of appointing as their patriarch a layman named Peter, son of Paul of the city of Callinicus; a man whom the blessed Jacob twice while he lived had endeavoured to raise to that office; and now again, after the death of the saint, they were desirous of consecrating him, but he would not consent, nor permit it; for he said, 'I can never agree to be set over a man who has not been cited canonically, and condemned and deposed according to law.' When, however, they proceeded to excommunicate him and eject him from the church, he was compelled to give way, and went, as was said, to Alexandria, and was there elected by Damianus and the rest, and named patriarch of Alexandiria in addition to Paul, while he still lived, and had never been condemned by a synod and deposed: so great was the corruption and confusion in the church of the believers by the instigation and to the delight of the devil. And the next scheme they formed was for all the abbots who had consented to this proceeding to meet together, and draw up letters signed by their own hands to John bishop of Ephesus, who was dwelling at the capital, to invite him to union and communion with them and their patriarch, without, however, telling

a The text has 882 , but the previous dates show that it was not till A. D. 58 1 that Peter Callinicus was consecrated. 
him openly the name of him whom they had elected. And John at this time, because he stood neutral between the two parties, was equally the object of blame to both sides, while all he could do was to grieve and mourn at the disruption occasioned by the envy and rancour of the Alexandrians, and the schisms throughout the whole church of the believers; and to admonish them and protest against their doings, and entirely refuse to take part with either one side or the other, or join in the conflict. And when he received these letters, he gave way to tears and bitter lamentation at this fresh ruin and confusion of the church; and could he have done as he pleased, he would not have answered them; but because a year before they had addressed other letters to him, and invited him to join them, and oppose the other side; and he had refused even to send them a reply, and they had mentioned this reproachfully in their present epistles, he was obliged to write an answer, though it was one of strong reproof, for having violated all canonical order in what they had done, and invited him to union and communion with them. And it is only their length that prevents him from inserting here both their letters to him and the answer which he sent.

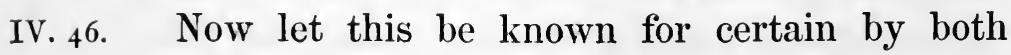
sides, who are thus embittered against one another by the instigation of the spirit of opposition, and to all men besides, that in whatsoever has been attempted or done by our unworthy 
selves, and in our narrative of the proceedings of both parties, we have had no other object than the truth's sake, in blaming and condemning both sides alike; nor have we written with the view of wounding individuals, nor for factious purposes; for, as may be seen, we have directed our reproofs and admonitions now against one party, and at another time against their opponents, and have exposed the factiousness and irregularity and illegal nature of their several proceedings. And this we have done, with our own mind full of grief and sorrow, and our eyes running down with tears, at the mischief and ruin and schism and quarrel and division and enmity and scorn and reproach stirred up between them, to the delight of the enemy of mankind. At the sight of these evils, we were constrained in sorrow of heart to blame them, because, being members and children of the same faith, they allowed themselves, for insufficient reasons, to rush without thought and without restraint into these unworthy deeds. And to this same effect we wrote at the very commencement of the quarrel, to the leading men personally, and especially to the laborious old man Jacob, and repeatedly urged our intercession to the very day of his death, in words like these: ' $I$, though but of inferior rank, keeping to the laws of the church, and not perceiving any errors in matters of faith, will neither abandon thy communion, nor that of Paul, because you are at variance with one another on canonical grounds, 
which may be true or may be false. And as to the other things which, without order or propriety, and contrary to the regulations of the church, have been or are now being done between you, I warn you, that if you anathematio the adherents of Paul, or depose him uncanoni. cally; or if Paul so treats you, or the Alexandrians; or the Alexandrians so treat you or Paul; for these illegal acts you shall never have part or communion with me, until all these things have been examined and inquired into in a legal and canonical investigation before a synod, and it is decided whose actions are in accordance with and maintain the laws of the church, and whose are at variance with order and propriety.' Ten times in separate letters we wrote to this effect in person to the blessed Jacoh, while he was yet alive, and similarly to the rest; and on this account, while I was full of grief and incessant sadness of heart, the accosation was brought against me by both parties, of nourishing opposition against them; lut I (all Him to witnesse, Who, triess the reins and heart, that I take no part either with one side: or the other, but remain strictly neutral up to this day, in grief and sighss and sorrow, at all the evils wrought by his instigation, who has asked to sift us as wheat.

IV. 47. As for Paul, the; patriarch of evil days, on finding that the conmity of the other side: was wo) inveterate ageainst firm, ho witholrew in seceret, and dwelt, as was said, in an cavern in the lofty 
mountains of Isauria", where he has continued for a period of four years, even unto this day. without being seen by any one, except the few who make answer for him: for he himself neither writes to any one nor receives their letters. And this has led to complaint and blame against him on the part of many, becanse of his withdrawing himself, and standing apart from the struggle maintained in every province on his behalf: and especially beciuse eren when his violent opponents consecrated another in his stead in Syria, yet eren so he neither shewed himself, nor spake a single word, but still remained at this present moment in concealment and silence.

Meamwhile Theodore, whom we have men- IV. 4 . tioneyl above as having been eonsecrated patriarch of Alexandria by Longinus and the rest. continued to dwell openly in Alexindria itself. observing the customs of his onder: for he had previously been a monk, and the head of a monastery, and in it he still calmly resided. and many gathered themselves round him. And becanse of his humility and pesceableness no man troubled him. or arove him from the city. although Damianus the sucessor of Peter. Was against him: but they let him slone knowing the swertmes of his temper. and that he suid,

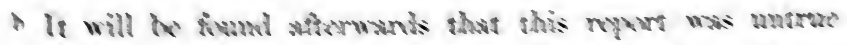

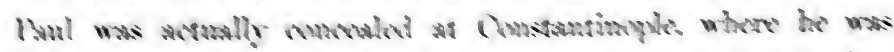

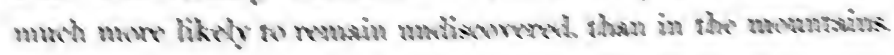


'My only care is, that there be no schism or disturbance in the church on my account.' In process, however, of time, he was grieved in mind at the conduct of Paul and Longinus; for Paul had hid himself, and paid no attention to any thing that was done; and Longinus had travelled still further onward, beyond the people of the Nobadx, to whom he had some time before returned, to another powerful tribe many score leagues beyond them, whom the Greeks call Alodæi, and who are supposed to be Ethiopians : but God had helped them, and spoken to their king and his princes, and to all the tribes under his rule, as we will in due time relate in order. But to return now to our former subject about Theodore; for by wishing to shew what were the fortunes of Paul and Longinus, our narrative has wandered away to a different subject. Being, as we said, vexed and annoyed at them both; 'for after coming,' said he, 'and exposing me to trouble, and getting me away from the desert, they have now left me, and neglect $m e$, and do not even inquire whether $I$ am alive or dead;' he wrote several letters expressive of his indiguation, both to Syria and also to myself, and to others at the capital, filled with complaints and vexation. And these he sent by the hands of a blessed man, a Stylite ${ }^{c}$, who had been

c After the example of Simeon Stylites, or the pillar-man, who spent most of his life standing on a pillar, which every year was raised higher and higher, numerous monks and hermits adopted 
with him in the desert, a person of great worth, and who came accompanied by a priest named George. And when we had received them, and the letters which they brought, and had comforted them much, and had also written a reproof on this account to the partisans of Paul, a violent persecution overtook us, and we were hurried away and removed from the city, and never saw them again. And subsequently he wrote to us again repeating the same complaint, upon the same grounds, but we think it best not to record it, but pass it over in silence for peace sake.

For far more pleasing is the subject to which IV. 49. we alluded above, namely, the conversion of the people whom the Greeks call Alodæi, but whom we believe to be Ethiopians, to the Christian faith. For to repeat some part of our previous narrative, it was by the zeal of the late queen Theodora that the blessed Julian was originally sent to the powerful people called Nobadæ, and taught both the king and his princes, and most of the tribes in his dominions, for a period of two years. And on his departure thence, he intrusted all that people to a certain Theodore, a very old man, and bishop of the city called Philæ, situated in the further part of the Thebais, on their

the same method of attaining to distinction : and naturally, for Simeon on his pillar became more powerful than any patriareh in the East, and all difficult matters, in church and state, were referred to his decision, which was received with undoubting faith and obedience as something infallible and inspired. 
borders, who went to them, and visited them, and gave them counsel, and returned to his own city; and so they continued for a period of eighteen years, more or less. And then it was that Longinus escaped in disguise, and went to them, and taught and instructed them afresh, and baptized such of them as had never partaken of this rite, and continued with them six years: and ambassadors moreover were sent by them to the king, and arrived at the capital, and we were repeatedly in their company, and heard them praising and extolling Longinus in the highest terms. And when the people of the Alodrei heard of the conversion of the Nobadæ, their king sent to the king of the Nobadæe, requesting him to permit the bishop who had taught and baptized them, to come and instruct them in like manner. But Longinus had just then received the letters from Alexandria, and hastily departed into the Roman territories, and fell into all the troubles one after another, which we have mentioned above. Subsequently, however, the king, with great labour and trouble and difficulty, managed to send ambassadors to him, who prevailed upon him to return with them to their territories. And the people of Alexandria, in their Satanic envy, wishing to set the king and his people against him, and turn them away from receiving him, drew up a formal act of deposition, iniquitously and against all canonical right, and sent it to the king; but he and his people would not look at it, or have anything to do with them, 
saying, ' We will not receive any one but our' spiritual father, who begot us again by a spiritual birth; and all that is said against him by his enemies we regard as falsehoods.' And so they sent the bearers away, and would have nothing to do with them.

Nevertheless, in spite of this failure, when the IV. 5 . Alexandrians learnt that the king of the Alodæi had despatched a second embassy to the king of the Nobadre, requesting him to let them have the same Longinus who had taught him, in envy, and not in zeal, they sent to that people, in the hope of setting them against Longinus, and of teaching them the same corruption and lawlessness of which they were themselves guilty. Accordingly, they hurriedly drew up a letter to them against Longinus, without fear of God, or regard for justice, being drunk, as it were, with envy, and the hatred that was in their hearts, and not reflecting that it.was a wrong thing to send to a people in the error of heathenism, and who now were asking to be converted unto Christianity, and to learn the fear of God, only confusion and offence, and the revilings of Christians against Christians, instead of those things which were useful for their edification. But, as Scripture says, ' their $E_{p}$ h. iv. mind was darkened, and their reason blinded, that they could not understand,' and therefore they were eager, even under these circumstances, to implant hatred and a cause of offence among this heathen people, instead of instruction in the fear of God; and with this view they sent letters 
to them against Longinus, the bearers of which were two of those bishops, whom, with many others, they had consecrated in opposition to church laws. And the letters were to this effect: 'Inasmuch as we have learnt that ye have requested permission for Longinus, who is in Nubia, to come unto you, to baptize you, we have sent you two bishops, and other persons, to give you instruction, that ye may not be baptized by him, for he is a heretic, and has been deposed, nor can he perform any of the functions of the priesthood, or baptize any one.' And much besides they wrote, to corrupt them, rather than admonish and inI Sam. struct them. 'But the Lord turned back the rexxv. 39. compense of Nabal upon his own head;' and, as it Rom. ix. is written, 'the heathen, who knew not the law 3 . of righteousness, attained to the law of righteousness, and were a law to their own selves; but Israel, which ran after righteousness, did not attain to it:' and this text was fulfilled here: for they were rebuked and put to shame by a heathen people, who would not receive them, and sent them back abashed and ashamed; for they said, 'We know not who you are, nor can we receive you, or be baptized by you : but we will receive him who baptized the Nobadæ, and by him will we be baptized. And as for what you say of him, we do not listen to it: for we see that you are his enemies, and speak thus of him from envy. Depart, therefore, from our land, that ye die not miserably.' And thus they had to retire, having neither been received themselves, nor 
their words; for God so ordered it, who saw their crooked devices, and the perverse spirit which had aroused their zeal.

Meanwhile the king of the Alodæi had, as we IV. 5 I. have mentioned, sent a second embassy to the king of the Nobadæ, requesting that the bishop Longinus might be sent to teach and baptize both him and his people: and it was plainly visible that the conversion of that kingdom was the good purpose of the grace of God. The Lord therefore stirred up the spirit of Longinus to go to them; and though the Nubians were grieved at being separated from him, they nevertheless sent with him nobles and princes and men well acquainted with the desert. Upon the journey, however, he became ill, as also did his companions : and so great were their privations, and the intensity of the heat, that, as he mentions in a letter, he lost in the desert no less than seventeen camels out of the baggage animals which accompanied him. Nor was this their only or chief danger; for between the Nobadæ and the Alodæi is a country inhabited by another people, called the Makoritad ${ }^{\mathrm{d}}$; and when their king heard that Longinus had started on his journey, Satan in his envy stirred him up to set watchers in all the passes of his kingdom on all the roads, both in the mountains and in the plains, as far as the sea of weeds ${ }^{\mathrm{e}}$, in hopes of arresting Longinus, and so hindering the salvation

d A district of Nubia still retains their name in its modern title of 'Maqorrah.'

e The sea of weeds is the constant appellation given by all Syriac writers to the Red Sea. 
of the powerful people of the Alodæi. But God preserved him, and blinded the eyes of those who wanted to seize him; and he passed through them, and went on his way, and they saw him not. And on his arrival at the borders of the kingdom to which he was travelling, the king, as he tells us in his letters, on hearing of it, sent one of his nobles to meet him, named Aitekiaf, who received him honourably, and made him pass over into their land with great pomp: and on approaching nearer, the king went out in person to meet him, and received him with great joy. And immediately upon his arrival, he spake unto the king and to all his nobles the word of God, and they opened their understandings, and listened with joy to what he said; and after a few days' instruction, both the king himself was baptized and all his nobles; and subsequently, in process of time, his people also. And so the king, being glad and joyful, wrote a letter of thanks to the king of the Nobadæ, as follows :

\section{Letter of the King of Alodia to the King of the Nubians.}

IV. 52. 'Thy love is remembered by us, my lord, our brother Orfiulog, because thou hast now shown thyself my true kinsman, and that not only in the body, but also in the spirit, in having sent me hither our common spiritual father, who has shown me the way of truth, and of the true

f This word, | |. $\mid$ |, Aitekia, is probably a corruption of the Greek name Eutychius.

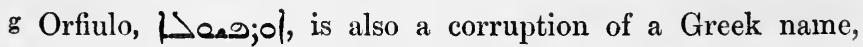
Eurypylus. 
light of Christ our God, and has baptized me, and my nobles, and all my family. And in every thing the work of Christ is multiplied, and I have hope in the holy God, and am desirous moreover of doing thy pleasure, and driving thy enemies from thy land. For he is not thy enemy alone, but also mine: for thy land is my land, and thy people my people. Let not thy courage therefore fail, but be manful and take courage: for it is impossible for me to be careless of thee and thy land, especially now that I have become a Christian, by the help of my father, the holy father Longinus. As we have need, however, of church furniture, get some ready for us : for I feel certain that thou wilt send me these things with carefulness, and I will make thee an answer: but on the day on which I was keeping festival, I did not wish to write, lest my letters should fail. Be not anxious then, but encourage thyself, and play the man: for Christ is with us.' Such then was the letter which this new confessor, the king of the Alodæi, wrote to the king of the Nobadæ. And next we will also give a short extract from a letter of the blessed Longinus, which he wrote from that land, and sent to the king of the Nobadæ, with a request that he would forward it to Alexandria: which also he did; and it is as follows :

'... Not then to trouble you with our an- IV. 53 . noyances, and make the letter tedious, I have omitted all such matters, and will tell you, se- 
condly, that which will rejoice all who are real Christians, and strict members of the orthodox communion: and I do rejoice with you all, and will rejoice, and ye in like manner must rejoice with me. And, moreover, rejoice with me in this, that He Who willeth that every man should be saved, and desireth not the death of a sinner, such as I am, but forgetteth all my sins, hath remembered His mercy and grace towards me, and opened for me the door of His mercy, and delivered me from those who were hunting after my life, and led me safely through them, and blinded their eyes that they saw me not. Nor were we unvisited by His lovingkindness in chastening us, in that all of us, with my unworthy self, fell ill, from the greatest even to the least; and I was the first to suffer: for it was but right that I should be chastened first, because I am guilty of many sins, and many are the offences into which I have fallen. And not only did we become ill ourselves, and despaired of our safety, but also the animals that were with us died, not being able to bear the heat, and the thirst in the mountains, and the unwholesomeness of the water, so that we lost no less than seventeen camels. And when the king of the Alodæi heard that I had determined to come to him, he sent one of his princes, named Itika ${ }^{h}$, who led me with great pomp into their land.

h The carelessness with which John of Ephesus spells is extreme : in this case $I$ have in each place given the name as he writes it. 
And on our arrival at the river's bank, we went on board a vessel; and the king hearing of our coming rejoiced, and came out in person to meet us, and received us with great joy. And by the grace of God we taught him, and have baptized him and his nobles and all his family; and the work of God grows daily. But inasmuch as there are certain Abyssinians, who have fallen into the malady of the fancy of Julianus ${ }^{i}$, and say, that Christ suffered in a body not capable of pain, or of death, we have told them what is the correct belief, and have required them to anathematize this heresy in writing, and have received these persons upon their presenting their recantation ..... And again, after some things̀ which we have omitted, he thus proceeds; ... And let all your rulers and people, on learning these things, offer up with spiritual joy their praises and thanksgivings to our merciful God, for all these His innumerable gifts; and let the fathers take care that there be sent down hither bishops, who will be able to labour and minister in this divine work, which is pleasing both to God and men, and in the reality of which they may feel confident, and that it is going on prosperously. For there are a thousand thousand here who are hastening to salvation, to the glory of Him Who is the Saviour of us all, even Christ.

i This is the Julianus of Halicarnassus, repeatedly referred to above, as the chief writer in defence of a heresy commonly held in the fifth century, of the body of our Lord being incorruptible. 
And believe what I say, that a short time ago a sort of purpose suggested by the weakness of human nature came to me, not to write to any one: but when I considered the danger which those incur who are negligent in their use of spiritual gifts, I have addressed this short letter to your spiritual love. For I desire neither silver, nor gold, nor dresses, as God is my witness, Who trieth the hearts of men, and Who knoweth all I do, and that I have not bread for my daily use, and am even glad to see with my eyes food of vegetables only. And thus far then let it suffice me to have told you.' This then was written by the holy Longinus himself, being extracts from the letter he sent from the land of the Alodxi to the king of the Nobadæ, with a request that he would forward it to Alexandria, which he accordingly did, to Theodore, whom Longinus had himself appointed as patriarch: and at the same time the king himself sent him a letter to inform him of Longinus' arrival among them, and his subsequent departure, and the trials and difficulties which stood in his way, and the gracious aid which God in His goodness gave him, and so forth; writing in admiration of him, to the following effect:

\section{Letter of the king of the Nobada to Theodore of Alexandria.}

'Before all things I especially desire your health in Christ, my blessed father; and next, my purpose is that you should know, that seven 
months ago the king of the powerful people of the Alodæi in Ethiopia, sent hither, to obtain from me, my holy father, the bishop Longinus, to baptize him. And it was done according to all that the holy king my father wrote unto me. For when I had mentioned the matter to my father, he at once readily and with good will assented thereto, and in his kindness promised to visit them. And every day he urged me on, saying, We must not neglect this business, for it is of God. But because of the wicked devices of him who dwells between us, I mean the king of the Makoritæ, I sent my saintly father to the king of the Blemyes, that he might conduct him thither by routes farther inland; but the Makorite heard also of this, and set people on the look out in all the passes of his kingdom, both in the mountains and in the plains, and as far as the sea of weeds, wishing to lay hands on my father, and put a stop to the good work of God, as my father has written hither to tell me. And great was the wearisomeness and the bitter trials of soul and body which he endured in the land of the Blemyes, together with extreme privation and want. And yet even so the wicked devices of his enemy could not hinder the readiness of my saintly father in doing the work of God; and the Lord our God directed his ways and ordered his paths so that he travelled safely over long tracks of country, and escaped the strong garrisons set in his way, although he lost his retinue of camels and the other beasts of 
burden with him. But God helped him, and delivered him, and he arrived at the land, and was joyfully received by the king and all the people; and he taught and baptized them, as we learn from the letter which he has sent hither. And this further you must know, how God the Lord of all has been with my father, and accompanied him, that ye may wonder greatly at what he has done unto him. For when the king, my uncle, and his royal ancestors used to send an embassy to that kingdom, the ambassador generally took eight or ten years in going and returning. But when my holy father went thither, within two hundred days he sent an embassy to us from the king, whereas many of my former ambassadors had never returned hither at all. And not to make my account too long, my father has sent me hither letters which I was to forward to you; and see, I have sent them by his ambassador; and in them he has given us an account of all that has happened to him, and all that he has done. And the news which his messenger has brought us, you must make known ; for it would not be right in your excellency to conceal and neglect all these matters: rather your holiness ought to aid my saintly father by your pious prayers.' Now this portion of the letter of the king of the Nobadre we insert here in confirmation of our narrative, because he bears witness to the whole of this providential history; and he wrote two others to the same effect, which we have not been able to insert for fear of making 
our story too long. And inasmuch as the main purport of this divine transaction is made known to every one, and declared by means of these two letters of the bishop and the king, we have determined not to lengthen the narrative by adding anything of our own, except to apply to these things, in token of our praise and admiration, the word of our Saviour, which says, 'Verily, Matt. I say unto you, that this good news of the king- xxiv. I4. dom shall be preached unto all the nations, and then shall the end be.' And these things then, which are now recorded by us, were done by the help of God in the year 891 (A. D. 580).

But to return now to the thread of our former IV. 54 . narrative, when above we mentioned the flight and concealment of Paul the patriarch, we said, as we believed ourselves, and as men generally supposed to be the case, that he had hid himself in a cave in the mountains of Isauria. But, as the fact finally proves, according to the assertion of those who find pleasure in investigating any thing thoroughly, during the four years in which he was out of sight, and was supposed to be hid in the mountains of Isauria, he really was concealed in the mountains near the capital. And though we were dwelling there, we were entirely unacquainted with the fact of his being so near us, nor did any one disclose it to us until his death. And those who were in his confidence imagined that even this was kept secret from us, and from men generally, and that three persons 
alone knew of his burial; but in so supposing they forgot the word of the Lord, which says, Matt. x. that 'there is nothing secret which shall not be 26. revealed.'

IV. 55. Paul's continued silence had been a source of great grief to Theodore; for during these four years he had never received an answer from him, though he had often written. And Longinus too, who had consecrated him, had gone far away unto those tribes who had been christianized by him in further Athiopia, and so Theodore was left without consolation on all sides. He determined, therefore, upon writing a circular letter to all the partisans of Paul, complaining and lamenting that he so neglected and despised him. And this he sent by two of his priests, who came to the capital; and on their arrival, their complaints and murmurs made the fact of Paul's concealment more generally known. And many were annoyed, and blamed Paul, and wrote wherever they thought he was, but he could not be found. And with much excuse and consolation, the priests were next sent to the island of Cyprus, because there were some of Paul's bishops there; and finally they returned to Theodore without having gained any thing by their journey. And he was still more distressed, and finally started for Cyprus himself in person.

IV. 56 . For when pope Theodore saw that he got no answer, either by letters or by the persons whom he sent, he determined to embark on board a vessel, and sail himself to the island of Cyprus. 
But he did not find Paul, but only some of his bishops, and though much discussion took place between them, still he could not discover where Paul was: two of the bishops, however, accompanied him back to Alexandria. And so he returned disappointed and rexed; for he did not believe what they said, that Paul was neither there nor in Cilicia, and that he could not see him. But, as was subsequently proved, during all this period of four years, in which no one saw him, and they had spread abroad the report that he lay hid in a cave in the mountains of Cilicia and Isauria, he really was dwelling in concealment in the capital, and but very few were privy to his secret. And there his end overtook him, of which we will now give a more particular account.

For while, as men thought, Paul was in the re- IV. 57. gions of the East, he really spent these four years in concealment in a mountain near the capital, as every one became aware at his death, though even then those who took care of him did their best to conceal it, and would not even have had it known that he was mortal. For after, as was said and proved, he had come to this city with the privity of a few members of his party, and had lain concealed with certain of them during all these years, suddenly he fell into a serious illness, and after a short time died. And great alarm and extreme terror fell upon them, lest if those in power should hear that he had been hid either in their houses or with their knowledge, they 
should get into danger on his account; and therefore they fetched three individuals only of those presbyters who were in communion with him, and exacted of them a solemn oath, that they would not tell any one that it was the remains of the patriarch Paul, but bade them say, if the truth were suspected, that an aged stranger, named Christopher, had come to the city, and died there. And this the three presbyters did, and took him up by night, with his face covered, and carried him for burial to a certain convent. And when the nuns heard their request to bury him, they were terrified, saying, 'We cannot receive a corpse at night, in the dark, without knowing who it is, or whether it may not be some person who has been murdered; for we shall get into trouble.' And when they earnestly besought them, saying, 'It is a great and righteous man, and a foreigner; be not afraid :' they were at length prevailed upon to admit him. And they brought him in, with a covering over his face, and began in great haste and hurry to let him down into the catacombs : but the nuns were angry, and said, 'If it is as ye affirm, and your words are true, that he is a great and righteous man, let us celebrate over him the proper service for the dead, and uncover his face, that we may see him, and bury him, and be blessed by him : and then ye shall let him down into the grave.' But they hastily wound him up in the graveclothes, and buried him, saying, 'Let us let him down at once, and go ; for we are in haste.' 
And so they buried him with the burial of an ass ${ }^{k}$, without any regard to decency, and went their way. And the nuns, who were more than a hundred and fifty in number, fell into many conjectures, and spread abroad various stories; and many different opinions were held, not only in the capital and in Syria, but also at Alexandria and everywhere else; but it was the general belief that it was Paul who was dead, though the three presbyters still stoutly affirmed and swore that it was another who had died, and not my lord Paul our patriarch. But all the orthodox at the capital, who acknowledged him as patriarch, were very indignant and angry that the secret of his death had been revealed to three of them, and kept secret from the rest; and many finally ceased to mention even Paul himself with love, and especially when they learnt that his arrival and residence in the capital, and death, had been concealed from them, and confided to three only of their number. But those who were privy to the secret still swore by a lying artifice that Paul was not dead, but alive; imagining that by so doing his opponents would not be able to rejoice. And for a whole year this dispute continued, and his name, as though he were alive, was proclaimed in the diptychs of the living, in the vain idea that his death would not be known as a certain fact, whereas really everybody did know it.

k That is, without any religious service being performed over his remains. 
IV. 58. And here our historian feels himself bound to make some solemn reflections upon the troubled deaths, one after another, of these two saints, Jacob and Paul, whose quarrel had led to so widespread a schism, and so bitter a dissension in the persecuted church of the believers. For no one, he says, can help wondering and clapping his hands, who considers how strikingly and suddenly and ignominiously they were taken from this present life, and made their exit from this world. For, first of all, the blessed Jacob, in the very heat of their quarrel and dispute, taking two other bishops with him and a number of monks, hurriedly hastened to Alexandria: but what was the purpose of his journey was kept a secret, and men held various opinions about it, some this and some that. But He Whose providence watches over the good of His creatures, saw perchance and knew that it was neither for his own good nor that of the church, and therefore hindered and prevented and forbade his arrival. Now a report, which some have spread abroad of him and his company, is, that when they had reached the sea, and begun their voyage, a violent storm arose, and their ship sunk, and all perished in the sea, and their corpses were never found. But evidently none can ever know whether this be true. And others, who zealously defend his memory, say, that even if the storm really happened, their ship did not sink, but they were thrown on land, and arrived at the borders of Egypt, and reached a monastery in the desert, 
called by the name of Cassian. And within three days after their arrival there, the two bishops first died, and then my lord Jacob, and then one of his deacons, all four together, one after another. And which of these stories is true, God knows; but we cannot say for certain. After then an interval of two or three years, the burial of Paul took place, in the confusion and absence of all right order, which we have briefly described in the previous chapter, and in secret, as those thought, who were the doers of it. And of these things what ought we to think and write, except to lament unto God with the prophet in sorrow and with sighs, and say, "If our sins testify Jer. xiv. against us, Lord have mercy for Thy name sake : ${ }^{7}$. for great is Thy goodness, and we have sinned against thee.'

The death of the two leaders led to various IV. 59 . attempts at healing the schism in the church: for on both sides men arose, and spake to one another about a reconciliation, but not in an upright manner, and with due regard to humility and the fear of God, but proudly and haughtily, each side thinking that it was the head, and that its neighbour was the tail; and that it was high and exalted, and pure and free from blame, while it sought to keep the other down, and make it take an inferior place. And each side threw upon the other the blame of causing all these evils and schisms and divisions, and each vaunted itself over the other, and swelled with pride, as though it was to receive 
the other as a penitent, and upon submission; for they had yielded themselves up to the teaching and malignity of the devil, who embittered them, and set them against one other, and so their path never led them to success.

IV. 6o. Peter alone, who had been made against his will patriarch of Syria, in Paul's place, endeavoured, with something like sincerity, to bring about a reconciliation: for even while Paul lived, being reproved by his own conscience, and by many also of his contemporaries, for having uncanonically occupied the throne of another while he was yet alive in the body, when finally the two parties began speaking to one another of a reconciliation; and those on Paul's side unanimously rebuked Peter, because, in Paul's lifePhil.i. 8 . time, he had set himself above him, Peter, 'whether in pretence or in truth,' or by cunning artifice, I know not, but certainly he began to say; ' Let there be no quarrel on my account: I will withdraw, and dwell in retirement: be ye then reconciled one side with the other: and appoint whomsoever ye shall in concert choose in $\mathrm{my}$ place, and so let there be union between you.' And when what he said pleased many, as bearing the appearance of humility and gentleness, others rebuked him even to his face, and called out reproachfully, 'Thou sayest this deceitfully, and in craft, and not honestly out of a pure heart: for thou knowest that those on thy side who set thee up, will never abandon thee: and besides, thou wilt make an excuse of Alexandria.' 
And when he heard this, and much besides, from many of them, to shew that he really was desirous of union, he arose, and took with him some of his partisans, and went to Alexandria, to urge them also, and Damianus, whom they had set over them as their head, to union. And after many matters had been mooted and discussed between them, it seemed, according to the word of the apostle quoted above, "whether in pretence or in truth,' that while he had spoken and argued much for union, they had resisted him, and would not listen to what he said: and so, as it seemed, he went away in vexation. But some thought that this was done artfully, and by cunning: but God, Who trieth the mind and heart, knoweth what is the real truth in these things. Because, however, they parted in peace with one another, therefore some concluded, that he had gone thither and back under a false pretence: especially because afterwards he stood firm in the quarrel, and said, 'I shall do nothing without the Alexandrians.'

Subsequently, for the space of a whole year IV. 6r. more or less, meetings on both sides of bishops and monks and others were held, in which they debated with one another, assembling now in one place, and now in another, and going to and fro, and sending messages, and exacting heavy and severe stipulations of one another, and treating one another, as we mentioned above, haughtily and despotically, and not in a friendly manner, 
and with brotherly love. And these stipulations they exacted first of all by messengers, who went to and fro, but subsequently in a more formal manner in writings, which they drew up to bind one another. But no sooner had a meeting risen and broken up, than there were found quarrelsome and litigious men, both of their number who had been present at the meeting, and others as well, who hindered peace, and put fresh causes of quarrel between the two parties; and giving themselves up to the spirit of opposition, they tore to pieces even the written conditions which they had mutually adopted, and circulated written attacks on one another, both to the capital, and the East and West, each one thinking his own the victorious side, and reviling the other, and accusing it, and often falsely, of every thing that would lead to the idea that it was in the wrong. And these mutual slanders they have often sent to me and others in the capital in the form of official deeds, and have not only refused to be the ambassadors of peace to one another, but have persisted in this division and schism and quarrel and opposition to one another, even to this day, and lived in a tempest of passion, such as gives pleasure to Satan, who asks for us, 'that he may sift us as wheat :' and by the false and disorderly dealing of both sides alike, who have refused to approach one another in the wish to examine dispassionately, in the fear of God, into the points in dispute, he has 
gained his end, and now dances with joy, in company with all his herds and hosts of devils, and rejoices in their mutual deeds.

Of these events then, we have briefly recorded the sum, not entering into all particulars, because of their too great length, from their commencement down to the present year, 896, (A.D. 585).

End of Book the Fourth; in which are contained sixty-one chapters. 


\section{E X C U R U S \\ UPON THE GEOGRAPHY OF NUBIA,}

AND UPON SOME

CHRISTIAN INSCRIPTIONS RECENTLY DISCOVERED THERE.

AS the names and districts mentioned in the foregoing narrative of the conversion of Nubia will probably be unknown to many of my readers, I have collected such traces of them as are to be found in Ritter's Erdkunde, Afrika, vol. i.; Quatremère's Mémoires sur lEgypte, and recent books of travels : and must also mention my obligations to Dr. Land, who has put many of these particulars into a clear and connected form.

While the countries to the north and south were early brought under the influence of Christianity, Nubia remained, owing to its physical conformation, a sealed land until the sixth century. From Alexandria, which claimed St. Mark as its first patriarch, the faith had quickly spread throughout Egypt, and as its deserts formed the refuge of the persecuted and oppressed, as well as of those who hoped to find in the monastic life closer communion with God, there was no portion of it which was not more or less completely occupied by Christians at a very early period. To the south, Abyssinia also venerated one of Apostolic times as the introducer there of Christianity, and in A. D. $33^{\circ}$ we have satisfactory historical evidence to prove that the piety and activity of Frumentius had carried the knowledge of the Gospel into every district of that land : but century after century elapsed before the name of Christ was heard in the intermediate region, except by the report of occasional merchants, or the hearsay of the ambassadors, who were yearly sent by the Nobades and Blemyes to Philæ to swear there not to plunder the Roman lands, and re- 
ceive in return their annual subsidy. The reason of this seclusion of Nubia from the zeal of Christian missionaries is to be found, as I have mentioned, in the physical formation of the country. South of Syene, from the first to the second cataract, extends a narrow valley, hemmed in on both sides by wastes of sand, capable of being traversed only by camels : but up the Nile travelling is still comparatively easy until the second cataract is reached. There not only is the channel of the river obstructed by a multitude of rocks, which render navigation impossible, but on each bank extends a district of steep and rugged precipices, which scarcely can be crossed with the consent of the natives; and, should they offer any resistance, a few men can oppose with success the progress of a numerous army. This region the Arabs call Batn-al-Hagar, 'the bosom of rocks ;' and its vast extent, both to the east and west, and the rugged nature of the surface, no longer practicable for camels like the previous wastes of sand, renders it one of the most impenetrable mountain fastnesses upon the face of the globe. At this rocky barrier commenced the country of the Nobades, from whom the whole region is now called Nubia, but whose dominions did not reach far beyond the third cataract, in the neighbourhood of which alone they possessed a district of somewhat level and fertile ground. As the Nile, a little below Syene, forms a deep bay, flowing first of all for several days' journey in a westerly direction, and then southward, until it has passed Dongola, where it turns sharply round, and for many scores of leagues doubles back towards the northeast, until finally half-way between the fourth and fifth cataract it resumes its original course, this rocky district is generally avoided by modern travellers, who take the direct route by land across the deserts between the Nile and the Red Sea. The narrow valley, which I have described above as lying between Syene and the second cataract, about seven days' journey in length, originally belonged to the Romans, but Diocletian withdrew their garrisons, and invited the Nobades to occupy it, upon condition of their protecting Egypt from the incursions of the Blemyes ; as a further inducement to which, they were to receive a yearly subsidy, and still more to secure the fair fields of Egypt from 
these marauders, he offered the Blemyes themselves a similar payment, upon condition of their abstaining from their ravages : and finally, at a subsequent period, the ambassadors of the two tribes went every year to Philæ, where they swore to observe the terms of the contract in the temple of Isis, and received the covenanted sum. The result was such as might have been expected ; for, secure in their fastnesses, the barbarians were constantly tempted by the prospect of immediate plunder to violate the Roman territories, and Diocletian was himself obliged to fortify the island of Philæ, and place a garrison there, and build also extensive works on each bank of the river. Upon the wall round Philæ one of the inscriptions is found commemorating bishop Theodore. In the sixth century it will appear that the Blemyes possessed the narrow Nile valley south of Syene, and that the Nobades had been driven back to their mountain fortress.

To the south, a district of swamp and morass still more completely isolated Nubia from Abyssinia. In these dreary marshes the Bahr-al-Aswad, or Black Nile, takes its rise, and forms the eastern boundary of the people called by John of Ephesus the Alodæans. On their western limit flowed the Bahr-al-Asrek, or Blue Nile; and as the southern marshes completely separate them from Abyssinia, their territory is constantly described as an island, and by the Greeks was called Meroe. Their capital, Sobah, erroneously styled Souïah by Quatremère, (i. e. سوية for سوربة : cf. Burckhardt, p. 530.) was situated near the confluence of the third great branch of the Nile, the Bahr-al-Abiud, or white river, with the Bahr-al-Azrek. This region still bears the name of Alouah, and its king, according to the Arabic authorities of Quatremère, is more powerful, and has larger armies, and more horses than the king of Makorrah, and his territory is more extensive and of greater fertility. The people are Jacobite Christians, and their bishops pay allegiance to Alexandria. Their religious books are in Greek, which the priests translate into the language of the natives. Alonah is a vast tract of level land, and of extreme fertility.

Between the Alodæans and the Nobades dwelt the Makoritæ, occupying the bay of the Nile from the third to the fifth cataract, 
with Dongola as their centre: while the deserts as far as the Red Sea were held by the predatory tribes of the Blemyes. The vast number of allusions to them in ancient times collected by Quatremère, t. ii. 128-132, suffice to shew the extremely harrassing nature of their inroads, and the vast tract of country over which they wandered. In Arabic times they still retained their marauding habits, and appear under the name of Bedjah as the worst enemies of Egypt. One of the most interesting traces of them occurs in Evagrius, who gives an account of the heretic Nestorius falling into their hands in one of their incursions into Egypt.

The same inaccessibility of the land which had long closed it against Christianity, served for its protection in the rapid progress soon afterwards of the Moslem arms. It is true that the Arabs entered the country in the 2 oth or 2 Ist year of the Hejira A. D. $64 \mathrm{I}$, but the flight of the Christians thither from Egypt for refuge, more than served as a counterpoise to the injuries inflicted upon them by the invaders. We find therefore the whole country overspread with Christian bishoprics, lists of which are still preserved, (conf. Wansleb, Histoire de l'église d'Alex.), and among them the names of the chief districts into which Nubia Christiana is divided are Noubadia, Aloodia, Makouria, and Niexemetes, i. e. Axumitis, the ancient name of Abyssinia, so called from its capital Axum.

In modern times the whole of this region has been carefully examined, and the inscriptions on its buildings and rocks copied both by the members of the commission sent out by the French government, and also by individual travellers; and the results, as far as regards our subject, have been ably summed up by M. Letronne, in three essays contained in his Materiaux pour l'histoire du Christianisme en Egypt, en Nubie, et en Abyssinie, 4 to. Paris, $183_{2}^{2}$. I find in it no less than four inscriptions commemorating Theodore, bishop of Philæ, whose name appears so often in our historian's narrative.

Three of these inscriptions are found on a wall in the temple of Isis, the pronaos of which was turned in Theodore's time into 
a Christian church. The naos, with its numerous small apartments, was unfitted for the publicity of Christian worship, and therefore the roomy pronaos was chosen in its stead. That this conversion took place subsequently to Justinian's time appears from the fact that that emperor renewed Diocletian's compact with the Nobades and Blemyes, and exacted from them an oath in this very temple of Isis. The bishop's alterations were not exactly such as would have pleased the æsthetic tendencies of an architectural society ; for having taken a pillar of red Egyptian granite covered with bas reliefs for the altar, he had both it and the whole pronaos covered over with a coating of plaster, which not only protected his flock from having their minds occupied during the hours of Christian service with the familiar emblems of idol worship, but has also admirably served to protect these sculptures from injury, and keep them unharmed to the present day. Upon the interior of the entrance leading from the naos into the pronaos two of the inscriptions commemorating the alterations are found, one on each side, as follows :-

I.

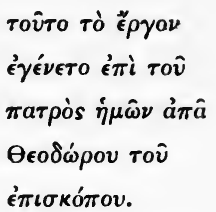

'This work was done in the time'of our father, abbot (àa for aßßâ) Theodore, the bishop.'

II.

\begin{tabular}{|c|}
\hline 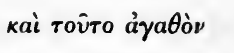 \\
\hline 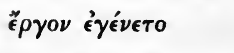 \\
\hline 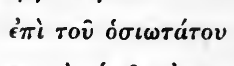 \\
\hline 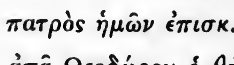 \\
\hline 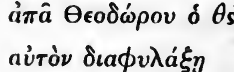 \\
\hline \\
\hline
\end{tabular}

'This good work was done when our most holy father, abbot 
Theodore, was bishop. May God preserve him for a very long time.'

In this inscription Letronne gives $0 \Theta 0$; but plainly the reading should be $0 \Theta c$, i. e. $\delta \theta \hat{s}$, contracted for $\delta \theta \epsilon \dot{s} s$, as the capital $\mathrm{C}$ differs from $\mathrm{O}$ only in not being a complete circle.

The third inscription was found just inside the outer entrance, near an image of St. Stephan, who had taken the place of the Egyptian Isis ; and is as follows :-

III,

$\tau[\hat{\eta}] \tau o \hat{v} \delta \epsilon \sigma \pi \delta \dot{\tau} \tau o v \dot{\eta} \mu \hat{\omega} \nu \mathrm{X} \rho \iota \tau \tau o \hat{v} \phi \iota \lambda a \nu$

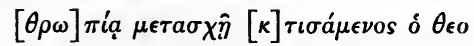

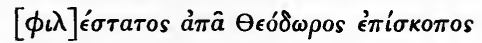

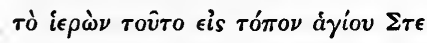

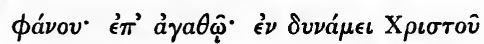

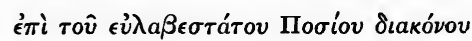

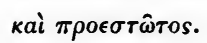

' May abbot Theodore the bishop most beloved of God share in the loving kindness of our master Christ for having made this temple $[i \epsilon \rho \dot{\omega} \nu=i \epsilon \rho \dot{\partial} \nu]$ into a place dedicated to S. Stephan. May a blessing rest upon it. It was accomplished by the aid of Christ when the most pious deacon Posias was provost.'

$\kappa \tau \iota \sigma a ́ \mu \epsilon \nu o s$ evidently refers to the plastering and repairs necessary for converting the pronaos into a church. The long $\omega$ in iє $\rho \dot{\omega} \nu$ is a mere mistake of the provincial sculptor. Posias, the provost of the college of deacons, has the honour of being mentioned, because the funds came through his hands, as it was usual for the oikovónos or manager of the ecclesiastical revenues to belong to that order.

Two crosses which occur in this inscription are remarkable for not being true crosses, but imitations of the Egyptian symbol, called the crux ansata. Christians noticed this symbol on Egyptian temples, and regarded it as a prophetic intimation of their future use, and therefore preserved it upon converting them into churches. Sozomen, vii. I5. 298, mentions the wonder with which Christians observed the repetition of this symbol upon the walls of the temple of Serapis at its destruction. 
The fourth inscription was found by M. Lenormant, carved on a wall of the quay on the south-east of the isle, forming part of the fortifications erected by Diocletian, but renewed and restored in Theodore's time. It is as follows :-

IV.

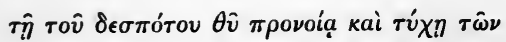

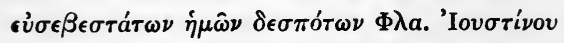

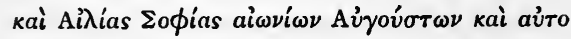

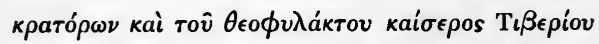

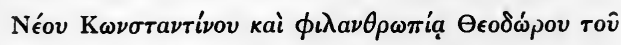

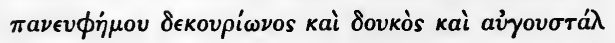

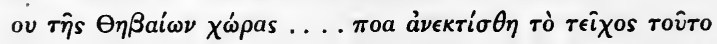

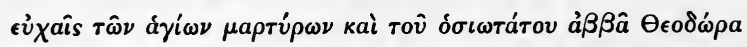

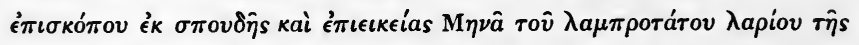

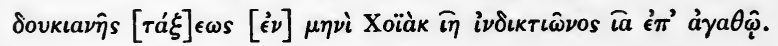

'By the providence of our Lord God, and the fortune of our most pious lords, Flavius Justinus and Elia Sophia, perpetual Augusti, and emperors, and of the God-defended Cæsar Tiberius, the new Constantine, and by the kindness of Theodore the most praiseworthy decurion and duke and augustal of the Theban district, this wall was rebuilt in answer to the prayers of the holy martyrs, and of the most saintly abbot Theodore the bishop, by the care and goodness of Menas, the most illustrious chartulary of the ducal archives, on the 18 th of the month Chœak, in the eleventh indiction. May a blessing rest upon it.

The date represents Dec. I 4, A. D. 577, the year before Justin

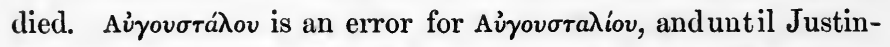
ian's time this epithet, which is equivalent to imperial, was confined to the prefect of all Egypt : it is now given to the duke of the Thebaid.

So also, in the days of Athanasius, the duke of Egypt was only

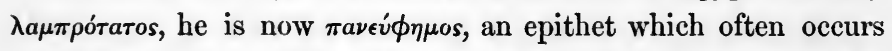

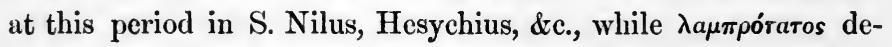
scends to the chartulary. The title decurion seems beneath the duke's rank, as we find it applied to inferior military o:cers, and even to the magistrates of municipal towns. But Letrome thinks 
Egypt may then have had ten nomes. . . roa is probably incorrectly copied, as it is difficult to suggest any word of which it

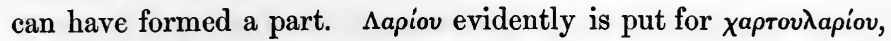
but whether the sculptor omitted one half by accident, or whether the title was shortened down in the vernacular of Philæ, is uncertain. Possibly, however, the correct reading is $\lambda a \mu \pi \rho \hat{o}$, and the copyist, instead of carefully decyphering what followed, XAPTOY, took it for granted that it was TATOY. 'H rásıs at this time was equal to rà тakrıkà, the public archives.

The solemnity of the inscription makes it evident that it commemorates the rebuilding of the entire wall : the necessity of which possibly was due to the hostility of the Blemyes, excited by the conversion of the temple of Isis to Clristian uses. Hence the piety of the inscription, the reference to the prayers of the martyrs, \&c. Shortly afterwards this danger was removed by the Blemyes being expelled by the converted Nobades from the Nile valley, and the people of Philæ had Christian neighbours.

We are informed of this in the most remarkable inscription as yet discovered in Nubia, and which has been copied both by M. Gau and Mr. Baillie, and commented upon by Niebuhr, Franz, Letronne, and others. It must have been engraved subsequently to Longinus' mission, but prior to the Moslem invasion in A. D. 64r ; and probably its date is shortly after the conversion of Nubia, if we may judge from the extraordinary ignorance it displays of Greek. It was discovered at Kalabsché, and the text, as given by Letronne, is as follows :

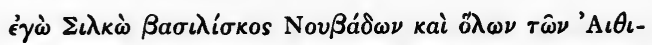

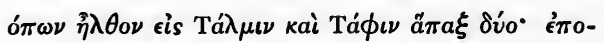

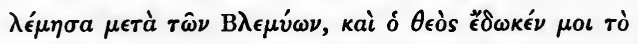

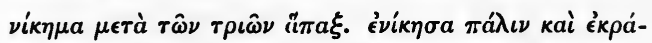

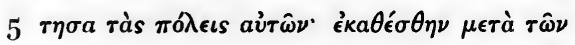

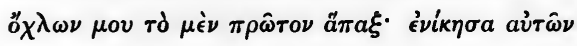

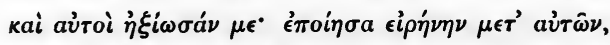

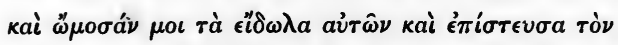

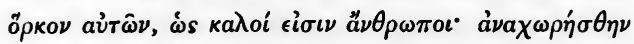

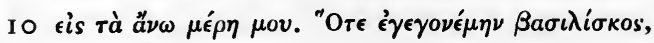




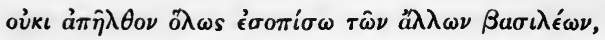

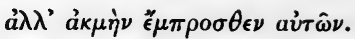

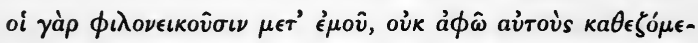

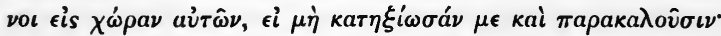

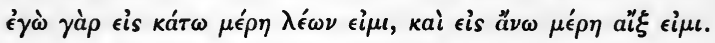

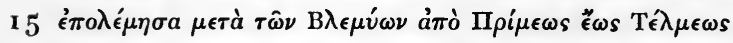

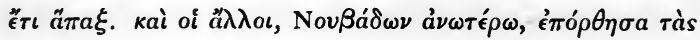

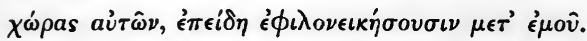

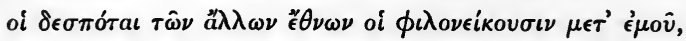

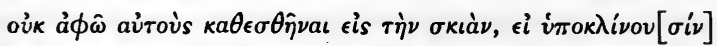
$20 \mu 0 \iota$, kaì oủk

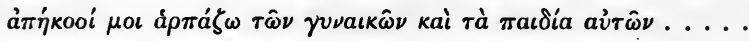

' I, Silco, the powerful king of the Noubades, and of all the Ethiopians, went to Talmis and Taphis onee, twice : I fought with the Blemyes, and God gave me the victory once and thrice besides. Again I conquered them, and took possession of their cities. Along with my hosts I settled there at the first once for all. I conquered them, and they begged for mercy. I made peace with them, and they swore to me by their idols, and I believed their oath, because they are worthy men. I withdrew to my upper dominions. When I beeame a king, I did not walk at all behind other kings, (but altogether in front of them). For those who cope with me, I do not suffer them to dwell in their land, unless they ask my permission, and entreat me. For I in my lower dominions am a lion, and in my upper dominions a goat. I warred with the Blemyes from Primis unto Telmis yet once again. And the rest, beyond the Noubades, I ravaged their territories, because they tried to cope with me. The sovereigns of other lands who eope with me, I do not permit them to dwell at ease in the shade, unless they submit to me, nor can they drink water (from the eisterns) within their house. For those who disobey me, I carry off their wives and their children . . . .

That Silco was a Christian king, is evident from his saying, 'God gave me the victory,' whereas a heathen, instead of speaking of God absolutely, would have mentioned the deity who was his peculiar patron. He also calls the gods of the Blemyes, idols, 
a word taken from the Septuagint, and used in this sense exclusively by Christians. Moreover, throughout the inscription the words are chiefly taken from the Septuagint, or used in a

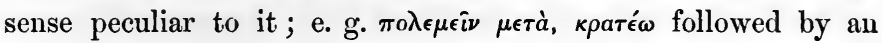
accus., $\mathfrak{a} \xi \iota 0$, ' to beg for mercy,' \&c. The towns mentioned, Talmis, Taphis, and Primis, are all in the narrow Nile valley, formerly ceded by Diocletian to the Noubades, but now evidently long occupied by the Blemyes; the first being the Kalabsché,

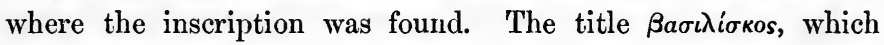
really is a diminutive, is probably adopted by Silco, as a longer

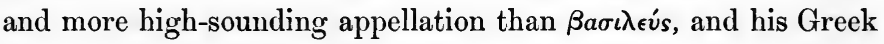
again fails in ${ }^{\lambda} \lambda \omega \nu$, which is used for $\sigma v \mu \pi a \dot{v} \tau \omega \nu$. In the next line $\delta v_{o}$ is for $\delta i s$, the meaning probably being, 'once and then a second time.' In line 4 , I doubt whether $\tau \rho \iota \hat{\omega} \nu$ is correctly copied, as $\mu \epsilon \tau \dot{a} \tau \hat{\omega} \nu \tau \rho \iota \hat{\omega} \nu a ̊ a \pi a \xi$ is a most extraordinary way of expressing 'four times.' The simplicity of the half line-' but altogether in front of them,'-carved in small letters between lines I I and I2, is most amusing: evidently it was an afterthought of king Silco, who was afraid lest posterity should put a wrong construction upon his claim to being unlike his ancestors. From line 12 the inscription is remarkable for the number of

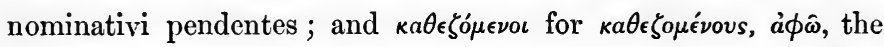
I. aorist subj. used for a present, and the discord of the tenses in $\kappa a \tau \eta \xi i \omega \sigma a \nu$ and $\pi a \rho a \kappa a \lambda o v \sigma \sigma \nu$, all suggest that Silco's Greek had been learnt by the ear alone. By being a lion in his lower dominions, he probably signifies, not merely the bravery of his subjects, but that to the south his empire extended to the flat lands inhabited by that animal, while his mountain fastnesses were the abode of the wild goat; and the two symbolized his activity and strength. In line ${ }_{5} 5$ begins the account of the second expedition against the Blemyes, referred to in line 2. The people beyond the Noubades are the Makorita ; in the account of whom, in line $\mathbf{1} 7$, occurs the most extraordinary slip, in $\phi_{i \lambda} \lambda$ $\nu \epsilon \iota \eta^{\prime} \sigma o v \sigma \iota \nu$, as Silco, in forming it, evidently considered that an augment added to a future tense changed it into an aorist. In line $\mathbf{I} 9, \epsilon \grave{i}$ is for $\epsilon \hat{\imath} \mu \grave{\eta}$, ' unless they submit to me :' and in line 20 ,

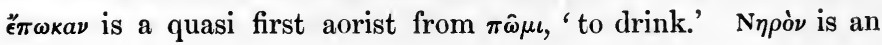


affected Byzantine word for 'water,' signifying, 'the moist.' In

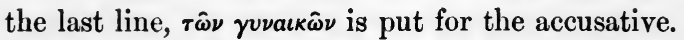

Niebuhr imagined that this inscription was possibly of the times of Diocletian, but his copy contained several mistakes, corrected by subsequent copyists, which led him to imagine that Silco was still a heathen. The more accurate text, and careful examination of Letronne, led him to assign to it its true date, about the end of the sixth century. With the narrative of John of Ephesus it so far coincides, that we find the Christian king, Orfiulo, promising to join his arms with the king of Nubia in a war upon the enemies of the latter: but whether the expedition ever took place, we have no means of determining. As however the invasion of the Arabs happened but a few years later, and rendered such conquests impossible, it is by no means impossible that the inscription records the success of the very expedition announced in John's pages, and that Silco was the first Christian king of Nubia. 


\section{BOOK THE FIF'TH.}

The first twelve chapters of the fifth book refer to the Tritheites, and will be found in the earlier part of the translation, where we have collected the scattered references to Conon, the Condobaudites, and other minor Monophysite sects. For so Timothy classes them, because however strongly opposed by Theodosius and the heads of the party, they nevertheless had sprung out from them, and agreed in holding their central doctrine of the complete union of the two natures in Christ. The rest of the book treats of the emperor Maurice, and in rearranging these chapters, we have done no more than our author recommends; for in his naive heading he says, "After the first twelve chapters it treats of the reign of the victorious Maurice, who ought indeed to have stood at the head of the book, but it did not occur to us.' And this same apology he repeats in his title to the thirteenth chapter.

His account of Maurice he commences ab ovo, V. I3. with the death of Justinian, in the fourteenth day of the month of November, 876 (A. D. 565), after a reign of thirty-nine years. His successor, Justin, his sister's son, reigned thirteen years all but forty days, during part of which, from the severe malady which visited him, Tiberius acted 
by his appointment as Cxesar, made on the seventh day of December, in the year 886 (A. D. $575)$; and subsequently, during his lifetime, he bestowed upon him the royal crown: for he saw that he was himself dying, and therefore raised him to the throne, for though he still survived, it was in the weakness and humiliation of death. The time he lived after making Tiberius king was nine days. Tiberius occupied the throne as Cesar for four years, and reigned afterwards as emperor for a period of four years more all but thirty-one days; and when he found himself sick unto death, he too was compelled to appoint as Cresar the count Maurice, the Cappadocian, on the fifth day of August in the year 893 (A. D. 582); for it had so happened, that Maurice had arrived at the capital but a few days before from the East, where he had been made commander-in-chief over all the Roman generals, as we have mentioned in the previous chapters upon this subject. He further gave him the name of Tiberius, and joined with him in the government his younger daughter, Augusta, to whom he also gave the name of Constantina, and made Maurice immediately take her as wife. The time he survived this appointment was only eight days, and when he saw himself sinking, on the day before his death, he further gave him the royal crown, and departed from this world in his suburban palace in the Hebdomum ${ }^{\text {a }}$; whence they brought him to

a This passage shows that the Hebdomum was still outside 
the palace in the city, and buried him after the manner of kings.

Meanwhile, the God-loving king Maurice sat V. I4. upon the royal throne, and showed himself, and was proclaimed as emperor, and began to manage and administer such matters as belong to the kingdom; and after the time of mourning for king Tiberius was påssed, he made great preparations, and arranged the affairs of the kingdom, with much pomp and magnificence, such as suits the majesty of kings. But these things it would not be easy for any one to detail without much labour, nor does our subject permit us to occupy ourselves with them, further than by an occasional allusion to such of them as are connected with the history of the church, which is our proper business. After the royal banquet, therefore, which was very splendid with magnificent presents and royal shows, the queen proved with child, and in due time a son was born to them in the purple, on the fourth day of August, 894 (A. D. 583), and they named him Theodosius,

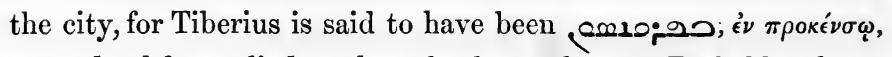
a word solely applied to the suburban palaces. Probably, therefore, Justinian only included a part of it within the city walls. It is mentioned as a place of recreation for the emperors by Rufinus, de vit. Pat. iii. 19. . . in Septimo, ubi solent imperatores egressi de civitate libenter degere. I have before mentioned the rumour that Tiberius was poisoned in a dish of mulberries. In the Chron. Alex. nothing more is said than $\tau \in \lambda \epsilon v \tau \hat{a}$

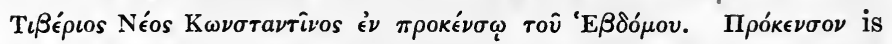
the Latin word 'processus' as transmuted by the Byzantine nasal pronunciation. 
in allusion to Theodosius the Second, who was the only one besides from the time of Constantine downwards who was born in the purple. For neither did Constantine beget a son after attaining to the empire, nor any one of those who succeeded him, neither Marcinus nor Leo, nor Zeno, nor Anastasius, nor Justin, nor Justinian, nor Justin the Second, nor Tiberius, down to the time of Maurice. Upon the birth, therefore, of the child, general rejoicing was made, especially because there were persons entirely unfit for so high an office, looking forward to and making preparations for seizing the kingdom by force: but on the day of this infant's birth, their projects were extinguished and brought to an end, so that even in the Hippodrome the people of the city, with loud shouts in his honour, said, 'God grant thee well; for thou hast freed us from subjection to many.' Forthwith, too, there were offered to the infant presents and gifts in abundance, by all the nobles and ladies of rank, and senators and others besides, each one trying his best to outdo his neighbour in the costliness of the offerings which were presented to him with great respect.

V. ${ }_{15}$. The commencement of a new reign is naturally favourable to designing men, and those therefore whose practice it is to make a pretext of men's religion in order to rob and plunder them, did not cease their endeavours to stir up Maurice against the orthodox, laying to their charge many wicked and unfounded accusations, while 
he neither knew what they held, nor what was the cause of their mutual divisions. As then they were constantly irritating him against them, he finally became angry, and summoned the patriarch, and commanded him to send and arrest and imprison such as would not communicate

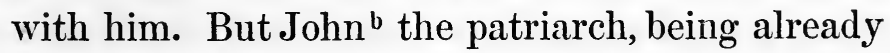
in grief and sorrow because of the heathen, since even after they had been detected and discovered by the providence of God, and convicted by the testimony of one another, and the legal depositions had been taken, and that not only in the capital, but in every region and city, as we have fully narrated above, and many members of the senate had been proved to be guilty, he then had let the matter rest, and thrown a veil over it, and but few of them had been put to death, and a few others sent into exile, while the rest of them continued as they were, and still held their rank and office. On this account the patriarch mourned inconsolably, so that when he was ordered to arrest and persecute the orthodox, he answered with indignation, 'Think you that God will be pleased that when we let heathens escape, and set them free, and acquit them, after their heathenism has been discovered and made known to every one, that now, after we have given them impunity, we persecute and condemn and slay Christians in their stead? Are these

b This was John the Faster, a very different character from John Scholasticus. 
the laws of justice? What do the distinguishers say or do that we ought to persecute them? Be it known then to your majesty, that as long as heathens are unpunished, and go at large, and not one of them is even deposed from his office, I know not how I can persecute Christians, with whose faith no fault can be found, and who consider themselves to be believers even more fully than ourselves.' And so for the present he put a stop to the persecution.

V. i5. A short time after these turbulent persons found some victims in the Arians: for as leave had always been refused to their repeated requests for permission to fall upon the congregations of the believers, they invented pretexts, and made numerous complaints against the Arians, and having assembled their whole troop, they fell upon an Arian church, the members of which met outside the city in the queen's monastery. The time chosen for the attack was when they were celebrating the communion, and having entered, they overturned their altar, and threw their oblations to the ground, and carried off all their vessels and books, and every thing else on which they could lay hands: and the people they dragged by force and imprisoned in the chancel of the church. And every one imprisoned there experienced the truth of the word of the Lord, Matt. v. where he says, "Verily I say unto thee, Thou 26. shalt not come out thence, until thou hast paid the uttermost farthing.' For not one of them 
was allowed to get out, until he had paid the very last farthing which he possessed in the world.

How much better those fared who were ac- V. 17. cused of heathenism, our author shews in the adventures of Gregory of Antioch, which we have detailed before. In the next chapter he tells us of the wealth and dignities conferred by Maurice upon his relatives, as follows:

At the beginning of his reign, the king sent V. 18. for his father, an old man named Paul, and his mother, and his brother, whose name was Peter, and his two sisters, one of whom was a widow, and the other the wife of Philippicus. The latter he first of all appointed comes excubitorum : and subsequently elevated him to the rank which he had himself previously held, of commander-inchief over all the Roman armies in the East, in which capacity he sent him to levy fresh forces to carry on the war against the Persians. And next he made his father head of the senate, and chief of all the patricians, and gave him and his son Peter, the king's brother, the entire property of the great patrician Marcellus, brother of the late king Justin, which was not much less than the royal demesnes themselves, with his houses and landed estates, and gold and silver, and his wardrobe, and every thing that he had everywhere without exception. And next he gave his father and mother another house near the church (of S. Sophia) and his own palace. Soon after he gave his sister and her husband Phi- 
lippicus a large and strong-built house, on the western side of the city, in the suburb called Zeugma $^{c}$; while his other sister, the widow, received a new and well-built mansion, lately erected by the patrician Peter, and which is almost as large as a city. He also gave to his other relatives large and noble houses belonging to the crown, and studiously enriched them in wealth and rank and honour, and gave them high offices near to the royal person, and in every way sought to increase their power: but as it is not the object of our book to treat of these things, we must omit their further detail.

v. 19. One relative, however, needs more particular mention, namely, Domitian, metropolitan of Melitene. Already Maurice, when sent by Tiberius to the East with the title of count, had shewn his devotion to the interests of his family by making him bishop of Melitene in Cappadocia: and when, after spending a period of two years more or less in the East, he had returned to the capital, and been made king, immediately Domitian hastened to him, and became his counsellor and most intimate adviser, and the person

c The suburb called Zeugma is said to have had its name from mules having been there yoked to the car on which the remains of the protomartyr S. Stephan were brought to the capital. The names of both the houses are given in the Syriac, namely, $\left.\omega_{r}\right\rangle$, and $\omega_{\text {, }}$, but I can find no traces of them in the Byzantine historians, though Theophanes, p. 229, gives an account of various buildings which Philippicus himself erected. 
who thought for him, and encouraged him in all the severe and painful difficulties with which he had to contend in the wars which pressed upon him on all sides, with the heathen and Magian people of the Persians, and the barbarous and savage tribes who came from the ends of the world, and are called Avars, and also with the Slavonians. And in all these difficulties the bishop of Melitene was the king's comforter and counsellor, although he was still but a young man. He was however thoroughly imbued with the opinions of the council of Chalcedon and of Leo. The great and important matters then, which pressed upon the empire on all sides, he laid before the king, together with his advice; and he let him settle them as he chose, and so he continues to do to this dayd.

On Maurice's elevation to the crown, his chief $\mathrm{V}$. 20 difficulty arose from finding that the lavishness of Tiberius had exhausted the treasures which Justin had stored up in the palace. For upon his becoming king, he found large sums of gold secretly hoarded there, which his predecessor had gathered by unjust means: and at the sight of it, as though some zealous spirit had entered into him, he began spending and scattering and dispersing it on all sides, sometimes fittingly and compassionately, or in the usual

d To this Domitianus of Melitene Maurice left the guardianship of his children, by his will dated in the fifteenth year of his reign : and Theoph. Simocatta praises him as $\delta \epsilon \xi i \dot{s} \tau i \dot{\nu} \pi \rho \hat{a} \xi \omega \nu$,

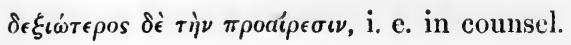


largesses to the army; and sometimes without thought or reason, as if he were throwing it about with a fan, until all Justin's treasures were expended, a large portion being consumed in his largesses at his accession. For as he himself said, he gave away then no less than seventyfive talents of gold, besides silver, and other royal matters, such as is the custom of kings to give; and finally, he was obliged to open the treasures of king Anastasius, and take money from thence. But when he departed from this world, and Maurice became king in his stead, he found the palace swept as clean as if it had been emptied with a broom, and was compelled therefore to take possession of any money that was discovered, or came in from the taxes, and withhold his hand, and effect savings in the expenses of the army, and hoard it up, saying, 'I must not disperse and scatter the money, but collect and store it up, that I may have the means of purchasing peace for the state.' And with this object he withheld his hand, and refrained from many of the customary observances, until he was much ridiculed and scoffed at by many, and called a close-fisted and miserly fellow, who could benefit and enrich none but his own relatives: and much more of the same sort was said, which, without some special reason, would not have been fit to record in a history of the church.

V. 21. Returning to ecclesiastical matters, our histo- 
rian informs us, that the rebuke of the patriarch, though ineffectual in preventing attempts at persecution, was not lost upon the king. For, in the midst of his difficulties and anxieties, from the wars which surrounded him on all sides, turbulent men, having no zeal for the faith, and using it only as a pretext for greedily plotting after the spoil of the houses and property of their neighbours, craftily endeavoured to get permission and authority to carry out their purpose, and never ceased wearying the ears of the king and patriarch with their constant calumnies, which, though not confined to them, were especially directed against those who found a stumblingblock in the council of Chalcedon. They complained therefore, saying, ' These men gather in large meetings, and celebrate the communion and baptism in greater numbers than the catholic church, even if you add to it all the heresies of Arians, and Samosatenians, and Tetraditese, and Manichreans ${ }^{\mathrm{f}}$, and Marcionites, and the like: and they disturb and upset the whole church. Give us therefore authority to arrest and imprison them, and put them to the torture, and root out all their meet-

e Several sects in the early church were ealled Tetradites, $\tau \epsilon-$

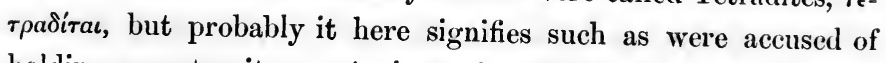
holding a quaternity, $\tau \epsilon \tau \rho \dot{s} s$, instead of the Holy Trinity. In this sense Dom. Macer applies it to the Manichees in his Hierolex., but probably our author intends by it the Nestorians.

f Although the word in the text obsuggests 'Montanists,' yet I imagine that it really signifies the Manichees, constantly called 6 by our author as being the followers of Manes. 
ing houses.' But the patriarch, being a gentle and merciful man, and who knew their cunning, and that their zeal was only for rapine and plunder, rebuked them, saying, 'If your zeal were upright in these things which you so press upon us, or if your purpose were the correction of these people, we should commend it : but as we know that your real object is to plunder and steal the goods of others, go and be quiet: for we will not permit any persecution to take place in our days, but to the best of our power will teach and admonish them.' And as these persons consisted not merely of clergymen, but also of laymen, some of whom were unsound in their Christianity -physicians, for instance, and heathens-who, besides their greediness for plunder, wished to make a demonstration also of their Christianity by professing zeal for the Christian faith, when they saw that the bishop would not submit to their cunning, they did not hesitate to din the ears of the merciful king himself, as some of them had access to him by being the royal physicians. But the king, as one whose whole conversation and all his thoughts were wrapped in the wars with the barbarians, would not even so much as listen to them, saying, 'Because we have not enough to do with the wars with the barbarians on all our confines, you want to bring upon us intestine wars also!' And thus their violence was restrained, and their projects were rebuffed and brought to nought.

Of the subsequent tragical fortunes of Maurice 
and his family our historian of course knows nothing: for his own death, at a good old age, apparently happened in the third or fourth year of Maurice's reign. His last notice of him is an account of his rebuilding the desolate city of Arabissus, in Cappadocia, a town remarkable on no other account than as being the emperor's birthplace, and the original seat of his family: and this new instance of devotion to his relatives naturally served to increase the ill-will entertained against him at the capital, on seeing all matters of state administered with so niggard a hand, while he loaded them with the highest offices and the most extravagant gifts. The narrative V. 22. is introduced by a statement, confirmed by coins still extant, that Maurice did not consent to the change of name commanded by Tiberius, who, on giving him the crown in his dying moments, had called him after himself, but persisted in using that only which had been given him by his parents, and would permit no other name than Maurice to be inscribed on his gold coins. From this he proceeds to mention, that a point on which he had greatly set his heart was the rebuilding and restoration of his native town of Arabissus. For this purpose he sent officersg into all quarters to collect skilful artificers in the

g These officers were called Scribones, and Du Cange quotes a passage from Gregory the Great, to prove that their duty was to travel into the provinces with the emperor's commands, and even sometimes with authority to see them executed. Their rank is shewn by his calling them 'viri magnifici.' 
working and chiselling of stones, and builders, and carpenters, and masons, and smiths, and mechanicians, and all other kinds of craftsmen, and stationed there a troop of soldiers, to keep them constantly engaged in the building, each occupied with his own branch of labour. His first command was, that the church should be taken down, and rebuilt on a larger and more magnificent scale: and he sent himself a large and splendid set of church-furniture of silver and gold, with beautiful vessels for the altar, and for the adornment of the whole building, and gave orders also for a large ciborium, such as is customary in all the churches of the capital, to be made here in pieces, and sent thither to be fixed up on the spot. After the church, his next order was for the erection of an extensive hospice, with lofty buildings: and next, for the public service of the city, a large townhall, and long and handsome porticoes followed, and magnificent basilicas, and a palace, and a strong wall. And much conversation and murmuring was made thereat; for people said, 'Every day he complains about the Roman armies, which labour and fight in behalf of the state, and says, I have no gold to distribute among them: and while there are numerous strong cities, both in the East and West, captured and laid in ruins by the barbarians, to which all he has to say is, I have no money to give, how is it that he now expends such and such a number of talents-and they mentioned a definite number, but as we cannot answer for its 
exactness, we do not record it in our history: they said, however,-How is it that he expends all these talents in rebuilding a town, which never was of consequence, nor of any value to the Roman state?'

But Maurice had soon a worse enemy to con- V. 23. tend with than the murmurs of his citizens : for two years after he had undertaken the restoration of his native town, and while the works were being rapidly pushed onwards to completion, suddenly a great and terrible earthquake happened, being the third which in succession have overthrown place after place in the East, and, as it were, in wrath, threw down the whole of Arabissus, and levelled all the buildings in it, new and old, to the ground. And all men wondered: but though the king Maurice was greatly vexed and troubled, and feared lest the overthrow of the city was by the secret indication of God, yet will he not desist from rebuilding it a second time: for all the artificers whom he had collected still remain there, apparently to renew their former attempt at restoring and rebuilding it again.

End of the Fifth Book of Church Histories, in which are contained twenty-three chapters. 


\section{BOOK THE SIXTH.}

Is the sixth and concluding book of John's history, he gives us a brief and affecting narrative of the wars by which the Roman empire was encompassed in his days; and as has constantly been the case in all troubled times, the good old man drew his strength and consolation from the belief that his Saviour's coming was close at hand. It was indeed close, but in a very different way from what he expected : for already the young Mahomet a, repelled in his first inquiries by the idolatrous aspect which Christianity outwardly bore, was rising to be the instrument of God's just anger against the eastern church. For the picture which John has drawn for us, especially in the fourth book, of the narrowness and bigotry, the fierce strifes, the want of self-restraint, the injustice and cruelty and utter absence of Christian charity, which characterized all parties in his days alike, makes us feel that the times were ripe for punishment. Not but that, possibly, there still remained some sparks of true faith; for it is the nature of history to record rather the external form than the inner life of the world's progress; and on its sur-

a Mahomet, who was born eirca A. D. 570, was seventeen or eighteen years of age at our author's death. 
face the bad and turbulent play a more important part than the virtuous and good. For virtue is, for the most part, uneventful, and holds on its calm and peaceful course unseen, except where the wickedness of others seeks to oppress and overwhelm it. And so with the history of the church: as a general rule, it is but a history of schism and heresy, of persecution and violence, and of the attempts now of this party and now of that to tyrannize over the consciences of others. But beneath there lies the golden thread, unseen too often, yet really there, of the grace which spiritualizes and ennobles man's earthly being; and though the general effect of reading ecclesiastical history in most ages of the church's existence is quite as much wonder at the all but total absence of the gentler Christian virtues, as admiration at the zeal which has never seemed to flag: yet one cannot but feel certain that there always have been in the church Christians in deed and in truth, on whose lives the doctrines which they professed had a better influence than merely to serve them as a battle field for contention and dispute. Whatever of these there were in the sixth century, we find at all events but faint indications of them in the pages of John's history, except in his own character; and though that is disfigured by much of the fanaticism of his time, so that he considers it a Christian duty to persecute heretics and heathens, yet in most respects we can fully feel with him, and admire the moderation of his character, brought out the 
more strongly into relief by the turbulence and intemperance of his contemporaries; and can therefore sympathise with the feelings which made him pen the introduction to this sixth book in the following terms :

VI. I. It has not seemed to us a thing improper or alien from our purpose to attach to these ecclesiastical narratives a short account also of the wars and battles and desolation and bloodshedding which have happened in our days, for the information of those who come after us, should the world continue to exist so long. And we record them to the best of our ability, and as we have learnt and received them by inquiry : being reminded by them of the word and lifegiving doctrine of our Saviour, where He teaches us, and warns and testifies to us of the time of the end and the consummation of the world, and also of Mat.xxiv. His advent, and says, "When ye have seen all 33. these things coming to pass, know that it has come even to the door.' And, lo! we in our days see all these things happening, and all accomplished, and therefore we ought always to expect His dread advent with great power and much glory.

The narrative commences about the year A. D. 574 with the military operations of the Patrician Marcian in the east. To throw some light upon his operations it may be necessary to recapitulate some of the facts of the previous history, namely, that in A. D. 571, the greater or Persian Armenia revolted from Khosrun, upon his endea- 
vouring, in violation of the compact with Sapor, to introduce there the Magian religion; but being unable to cope with the Persian monarch singlehanded, they offered their allegiance to Rome. Their submission was accepted, and orders were sent to the Roman commanders to defend Armenia as part of the Roman dominions. At first the efforts of the Armenians were crowned with success, and a great victory, which they gained under the Mamigonean chief Vartan over the army of Khosrun, needed only to have been vigorously followed up to have insured final success. How the incapacity of a despotic court, jealous of its own officers, and more intent on petty intrigues than careful for the general good, thwarted the efforts of its generals, and both lost Armenia, and was compelled to submit to an inglorious peace, will best appear in the simple narrative of our author.

The illustrious Patrician Marcian, a relative of VI. 2. king Justin, was sent by him to command one of the Roman armies in the east; and being warmly zealous for the polity of the Christians, he assembled an army, and laid siege to Nisibis, the frontier town and bulwark of Mesopotamia, and then in possession of the Persians. And having strongly invested it, and constructed round it a palisade, he commenced, with the aid of the skilful mechanicians whom he had brought with him, to erect more scientific works, consisting of lofty towers and strong covered approaches. And the city began to be distressed, 
and both its inhabitants and the Persian garrison despaired of their lives when they saw it so hard pressed by the Romans. And as those inside were in alarm, so those outside were making their preparations to assault the city and plunder it; but just as they were ready to storm it, a violent tempered man arrived, named Acacius Archelaus, sent for no just reason by king Justin to deprive Marcian of his command, and cut his girdle ${ }^{b}$, and send him away from the east. And immediately that he came he showed his orders, just at the time when Marcian and his army were fighting against Nisibis, and expecting to assault it the next day, and win the city; and all were in astonishment, and their hands were weakened. And the illustrious Marcian, who had been assiduously making his preparations, and was upon the point of capturing Nisibis, on hearing the orders, said to Acacius, 'You see how great labour we have taken for the purpose of capturing this city; and now, wait a little, and grant us a delay of two days only, and then do what you have been commanded; for the king has a right that what he orders should be done.' But he was angry with him, and insulted him, and in hot wrath laid hands upon him in the presence of all his officers, and pulled him about, and threw him down, and cut his girdle, scoffing at him, and even, as was. said, he struck him on the cheek. And the

b This is the usual phrase for depriving an officer of his command, especially when it is intended to disgrace him. 
whole army was indignant, and their hands weakened, and execrating the wickedness which had been done before their eyes, they lowered their standard, and turned it upside down. And thereupon the whole army fled, and left the city far behind them, and loud was their grief and lamentation at what had happened to their commander; for he was a good man and a believer: and besides, at the very time when they were expecting to enter and take the city, they had shown their backs when there was no enemy who pursued them, and had become the laughter and scorn of their foes. And when the Persian army which garrisoned the city saw the breaking up and sudden retreat of the Romans, and Marcian's standard overthrown, they were astonished, and encouraged one another, and armed and pursued after them, and fell upon a body of infantry which remained behind, and defeated and slew most of them, and so returned to the city, laughing and mocking at what had happened to the Romans of their own selves. Forthwith, too, they wrote and informed their king of all these things, saying, 'Come, immediately, and let us cross over into the Roman territory; for our noble gods, the sun and fire, have made them, by the commandment of their king, fall upon one another; and they have dismissed Marcian with scorn, and have all fled and gone away from our city.'

The anger of Justin against Marcian arose from no fault of the latter, but rather from the unbusinesslike habits of the king himself, who 
allowed the underhand dealings of the weak court of Constantinople to come to light by a carelessness as indefensible as the treachery it

VI. 3. disclosed was base. The account of it is as follows: The Tayenses, or Arabs of the north, were at that time divided into two sections, of which the one was allied with Rome, the other with the Persians. Of the former Harith was king, and was held in such general awe and terror by all the nomad tribes, that as long as he lived, no one ventured to disturb the peace. But upon his death the Arabs in alliance with Persia looked with contempt upon his sons and princes and army, and imagined that, ' lo! now at length all his encampment is delivered into our hands!' Accordingly they gathered themselves together, and pitched their camp in Harith's territories, bringing with them all their flocks, and vast herds of camels. But when Mondir, Harith's eldest son, heard of it, he was very wroth, and burnt with zeal, and taking with him his brothers and sons and nobles and all his army, he fell suddenly upon them, whereas they had expected that he would never venture to make any resistance. They were utterly defeated, therefore, and put to the sword, and their king Kabus, when he saw the fierce onset made by Mondir and his troops, and that already they had broken through and overpowered and slaughtered his hordes, turned his horse, and fled with a few companions, and succeeded in making his escape, but saved nothing of his property. And Mondir 
entered, and took possession of Kabus' tent, and his entire encampment, and all his baggage, and his herds of camels. Several also of his relatives he made prisoners, and some of his nobles, but the rest he put to the sword. And next he crossed over the Euphrates, and pitched his camp in the territories of Kabus, and marched inland to the distance of sixty leagues, and arrived at the place where the herds and all the riches of the Persian Arabs were. There he pitched his camp for some time, and the hordes of Kabus, on seeing their master's well known tent erected so far in their land, boldly came to it, expecting to find their king there, but on entering, found themselves in Mondir's camp, and were seized and put to death, except some of note, who were kept as prisoners. And after staying there as long as he chose, he set out upon his return with much spoil, consisting of herds of horses and camels and armour and so forth. And after some time had elapsed, Kabus also collected his forces, and sent to Mondir, bidding him meet him in battle: ' for, lo!' said he, 'we are coming upon thee. For though thou didst fall upon us a thief, and imaginedst that thou defeatedst us, behold, we openly draw near to thee for battle.' But Mondir sent in reply, 'Why do ye trouble yourselves? for I am already on my way.' And not only did he consent and make preparations, but with the word effected also the deed. For he met them suddenly in the desert, when they did not expect him, and fell upon B b 2 
them, and threw them into confusion, and slew most of them; and again they fled before him. But inasmuch as we have previously given an account of these achievements elsewhere in our history, our purpose now is to record the iniquitous plot formed against him in violation of all right feeling after these glorious victories, and so great a triumph in two successive battles. For, as Mondir imagined that his success would be acceptable and extolled by the king, he wrote to him an account of all that he had done, and his complete victory; and added a request that he would send him gold that he might hire troops; because be expected that certainly they would gather their forces once more to attack him. And when king Justin heard that he had written to him to send him gold, he was angry, and very indignant, and reviled him, and vowed vengeance against him, and secretly determined in his heart to murder him by some artifice or other.

VI. 4. Thus then being filled with the spirit of opposition, king Justin wrote a letter to the patrician Marcian with the intention of having Mondir secretly put to death; and the letter was as follows: "I have written to Mondir the Arab to bid him come to thee: see, directly that he comes, that thou take off his head, and write and inform me of it. To Mondir I have written in these words: Because of some matters of importance, I have written to the patrician Marcian, requesting him to confer with thee; go therefore to him immediately without delay, and consult with him 
upon the matters in question.' But, as became subsequently known to everybody, the letters, by the providence of God, were changed, and the name of Mondir himself was inscribed upon the despatch, directing Marcian to take off Mondir's head; while, by some mistake or other, the letter intended for Mondir was directed to Marcian: and the messenger who started with the two despatches, having delivered them to the persons to whom they were severally addressed, it happened that Mondir received the despatch which gave directions to Marcian to take off his head; and Marcian, on the other hand, that which required Mondir to go to Marcian, to hold the proposed conference. When then Mondir received the despatch, and had read it, he was greatly agitated, and said, 'In return then for my labours and anxieties in behalf of the Roman territory, my reward is the loss of my head. This is my desert.' And being filled with anger, he collected all his people, and bade them provide for his safety, saying, 'If you see any one whomsoever sent unto me from the king of the Romans, if he has but a small escort, seize them, and keep them closely guarded outside your encampment: but if the escort is numerous, at once advance boldly and fall upon them, without giving the slightest credence to anything whatsoever which they shall say unto you, or permitting them to approach on any pretence into the neighbourhood of your encampment.' And thus uninterruptedly day and night the Arab hordes kept armed watch in de- 
fence of their king, being ever on the look-out, and ready for battle with any one whomsoever who should come unto them from the Romans. And when the Persians, and the Arabs under the Persian rule, heard the news, and learnt that they had now nothing to fear from Mondir, and that he would not trouble himself to engage in war for the sake of the Romans, who had tried to murder him, they boldly made preparations for invading the Roman territory, and laid it waste with fire and sword as far as Antioch, and captured an immense number of prisoners, and ruined and razed and burnt large and strong towns, almost equal in size to cities, both in the territory of Antioch and elsewhere, and took the inhabitants prisoners, and utterly ruined all these countries, and returned to their land with a mighty spoil. But Mondir was full of grief and lamentation at the treachery of the Romans towards him, and at the devastation wrought by his enemies, and the wealth which they had carried away from the Roman land: and therefore he gathered his people, and withdrew into the deserts. All meanwhile who heard of the wickedness which had been purposed against him, without fault on his side, were greatly displeased, and blamed it, and found fault with commands so contrary both to reason and justice. And when the king heard that this was said on all sides, and learnt moreover that Mondir had abandoned all care of the Roman territories, he sent orders to the chiefs and generals in the East, command- 
ing them to go to him, and persuade him to be reconciled to them. And when many of them sent to him proposing to visit him, the answer he returned to each one was; ' Be well assured, that any one whosoever who comes unto me from the Roman dominions, I shall resist his approach by force, so that either he shall kill me, or I will kill him. For God forbid that I should ever again entrust my life to any Roman; for, as far as it depended upon you and your king, my head is already off. For this was the fate to which I was condemned by the Romans.' And this state of things continued for two or three years, during which repeated attempts were made to prevail upon him to consent to a reconciliation; but he would not permit any one to approach him, but sent about Justin's despatch, commanding his murder, in all directions, and shewed it to every one.

The displeasure therefore which was entertained against Marcian was because Mondir had escaped and was still alive, while the secret had been revealed and become known, and the plot consequently had been unsuccessful. For all men knew what the sentence was which had been decreed against him iniquitously and wickedly, and without regard to the fear of God. But after king Mondir had given way to his indignation, and stood with his forces carefully on his guard against all the princes and armies of the Roman realm, for a period of three years, more or less, then, as being a Christian, and grieved at the miseries which had fallen upon the Roman terri- 
tories, and full of anger against the Persian Arabs, who had carried fire and sword, and made captives of the people as far as Antioch, and had returned to their land with an immense spoil and prisoners without number, he determined to make peace, and take up arms for the Roman state. And as he would not consent to receive the letters which were constantly sent to him from the king by the hand of many of the princes, in which Justin denied all privity to the attempt, and said that the orders to kill him were not written with his knowledge, but continued to shew his resentment, and would not admit to his presence either the bearers or the despatches themselves, but stood ready for war with all who should venture to approach near his camp: he finally determined himself to send to the patrician Justinian, the son of Germanus, who at that time was head and commander-in-chief over the armies of the Romans in the East, a message to this effect: 'Directly that I heard and learnt the plots of the Romans, and knew that I was doomed to a certain death, in return for my exertions in their behalf, I felt that henceforward it would be impossible to trust myself in the hands of any of the Roman princes for ever. But because I know thee to be a Christian, and a nobleman who fears God, if thou wilt go to the house of the blessed Mar Sergius at Resef c, and send

c Rezeph, Jer. xxxvii. I 2, the 'P' a day's journey from the well-known town of Thapsacus on the Euphrates. As Sergius and Bacchus were the patron saints of 
me word, I will come to thee there, with my men armed ready for battle: and if peace meet me, and true dealing on thy part, we will converse together, and finally both of us depart in amity: but if I find any treachery, I trust that the God in Whom I believe will not relax His care of me.'

When the patrician Justinian received the message, he was very glad, and sent in answer; 'Entertain no suspicions of me: for, lo! the God of the Christians is between us. Come on such a day to the holy house of Mar Sergius, and thou shalt find me there: and trouble not thy army; for I trust in God that we shall separate from one another in peace and love and concord.' And when Mondir received this answer, he proceeded thither immediately, but changed his mind respecting his escort, and took but few attendants with him; and on his arrival, the two remained alone before the shrine in which were deposited the bones of the holy Mar Sergius; and after a conversation too long to record, and they had mutually given each other their word, they departed in confidence and peace with one another, and great joy. And when the news reached king Justin and the senate, they also rejoiced greatly, that Mondir had consented to make peace: and subsequently letters of peace and reconciliation were interchanged between the two kings. And after a short time, the warlike and spirited king

the Syrians, churches and monasteries were too frequently dedicated to them for it to be surprising that no other mention of this monastery occurs in history. 
Mondir, being full of anger at the audacity of the Persian Arabs, and desirous of tearing away and stripping them of the prey which they had taken from the Roman territory, quietly gathered his brothers, and all his relatives, and his sons, with their forces, and bade them immediately make rapid preparations, and get their arms and provisions ready, and meet all together on the second day at his tent. And on their assembling with great promptitude, he revealed to them his purpose, saying; 'Immediately, without any one separating himself or withdrawing from us, let us all fall suddenly on Hirah, the capital of Noman, in the Persian territories; for, to punish their boastfulness, and insulting violence against the Christians, God will deliver them into our hands.' Immediately therefore they set out with speed, and reached Hirah, and fell upon it suddenly, when its inhabitants were in peace and tranquillity; and they surprised them, and put to the sword and destroyed the garrison there, and overthrew and uprooted and burnt the whole town, with the exception of the churches. And Mondir pitched his tent in the middle of it, and remained there five days, and bound such Arabs as he had taken prisoners, and drove off all the booty of Hirah, and every thing which they had captured and brought away from the Roman territories, and all their herds of horses and their camels, and so returned to his land, in great triumph, and after a decisive victory. And it even more increased his glory and magnificence, that 
he liberally gave presents to all the churches and monasteries of the orthodox, and especially to the poor. For all men extolled him, and the two neighbouring realms of Rome and Persia admired and wondered at his spirit, and the martial exploits and victories which he had achieved.

The discovery, therefore, of Justin's treachery VI. 5 . against Mondir, brought about by the carelessness of the clerks at Constantinople, was the sole reason why Marcian was deprived' of his command at the very moment when the capture of Nisibis seemed certain, whereby the eastern confines of the Roman territories would have been secured against the inroads of the Persians. But the retribution which fell upon the Roman realm was not confined to this check upon their onward progress; for no sooner had the Persian king heard of Marcian's fall, and the breaking up of the armies before Nisibis, than he determined to take full advantage of the mismanagement of his enemies, and assembling a powerful force, arrived rapidly at that town, and found the engines and machines which Marcian had erected still standing before it. And with these he forthwith commenced the siege of Dara, having removed thither all Marcian's engines of war, and applied them to his own use, for which purpose he had brought all kinds of artificers with him. His first act was to command the stone-cutters and others to make a cutting through a hill which lay on the east of the city outside the aqueduct, in order to divert the water; and when, as was said, 
they found the stone hard, they lit fires upon it, and cooled it when hot with vinegar, and so made it soft for working. He further set up against the city all the engines which Marcian had constructed against Nisibis, and invested it, and used every device of war for its capture during a period of six months. Among his machines were two towers, which he erected, but the Romans devised a plan for setting them on fire, and were successful, and burnt them, although all egress from the city was impossible. On the side of the besieged the generals were John, the son of Timus Esthartus, a man of great warlike ability, and Sergius, the son of Shaphnai, and others. But Sergius, as they said, was struck by an arrow and died. After a time the Persian king, not finding the siege making progress, removed his tent and pitched it on a mountain on the northern side of the city, whence he could see every thing that was done within. And there also he ordered a tower to be built on more elevated ground, opposite a great turret which rose higher than the rest, and which they called Hercules. And against this the besieged found all their efforts unavailing, while the besiegers were able to strengthen their tower, and bring it up close to the city. Sometime before this, when the king saw that his vast works had not terrified the inhabitants, he had given orders for a brick wall to be drawn all round the outer fortifications, that if they made a sally, they might be caught within it. But when he saw that all 
his stratagems were in vain, he fell ill, as was said, and was afraid lest he should die. He, therefore, sent a messenger to the city, requesting them to appoint some one to confer with him. Now there was there at the time a famous and illustrious man, named Cometes, whose office it was to interpret between the Romans and the Persians, and him the citizens chose as their deputy. And after a conference, the king said to him, "Tell the citizens they must give us five talents as ransom for the city, and we will withdraw from it.' But he, as he acknowledged afterwards, being confident that the city was impregnable, did not tell them of the king's offer. And when the king saw that the appointed day had passed by, and that they despised him, and sent him no answer, he was the more angry, and full of great wrath ; and attacked the city again, and strengthened and increased the tower which he had last built. But the Romans now despised and mocked him, and said, 'He will get only shame from this as from his other attempts.' But this over-confidence led them to neglect the maintenance of a proper force upon the wall, especially as the cold was now great and intense; and they even came down from the ramparts, and went to their houses to eat and drink. But when the Persians saw that the wall was no longer guarded by the Roman soldiers, and that the tower which they had built exceeded the height of the fortifications, they set their invention to work, and fastened planks together, 
until they reached the wall; and passing over, they occupied the whole of it on one side of the city, and then began to descend within. And when on a sudden a cry was raised, that the city was taken, as the Persian army was far more numerous than the Romans, they were panic stricken and in confusion; and all ran in crowds to the gates of the city to endeavour, if they possibly could, to escape. And when the Persians saw how numerous they were, they again were afiaid, and anxious, and held back, and gave the Romans room to flee, lest they should turn and defend themselves. The Romans then ran to all the gates, and shouted for the keys, and search was made, but no keys could be found, for the generals had hidden them; and as they saw that the Persians were growing every minute more numerous, and that the whole city was aiready full of them, and that they were hemmed in on all sides, and flight impossible, they recovered their courage, and threw themselves upon the enemy, prepared either to live or die. And so like harvest men they began mowing and smiting one another down like ears of corn; and the battle was stern in the heart of the city, and for seven days, with the gates still closed, they slaughtered one another, till the city was full of corpses, the smell of which became so unbearable, that they were obliged to drag them away, and throw them into the river and the cisterns. And when the Persians saw that they were losing great numbers 
of their men, and that they could not get possession of the city, and take its spoil, being terrified moreover at the Romans, they fled and mounted upon the wall, and took counsel how they might effect their purpose by fraud. They sent a message, therefore, to them, saying, "Why thus do we slaughter and consume one another? Come, and let us mutually pledge our word, and lay aside our weapons on both sides, and make peace with one another.' And as the Roman host now despaired of their lives, and saw that they were pressed by necessity, they accepted the proposal, and both sides pledged their word, and laid aside their arms, and approached one another confidently as in peace. And as the Romans put confidence in their word, they were without fear; but upon this a strong body of Persians entered the city, and at first both sides mingled with one another in peace; but soon they began to plunder the city; and the fraud and perfidy of the Persians was made manifest. For they turned round and proved false to their word, and seized the Romans themselves, and put most of them to the sword; and the rest they threw into chains, and took them to their king, with their nobles, and women of rank, and their princes; and the king commanded them to be drowned in the river which flows by. And next he commanded that every one who had gold should bring it to him; and that all the gold and silver that was found should be collected at his tent; and in this way an immense quantity of gold 
was gathered, more, as was said, than a hundred or even two hundred talents, and piled up before him. As we are not however acquainted with the exact sum, we do not wish to decide falsely, but prefer passing by in silence whatever we have no means of knowing accurately. The king then, when he saw all this gold, called for the chief men of the city, and said to them, 'May the great God of heaven require at your hands the blood of all the souls that have perished on your side and on mine, since I did not ask of you so much as the hundredth part of the gold which is here piled up, to be given as the ransom for your city, and then I would have gone away. For to this effect I sent to you by Cometes, and ye paid no heed to me.' And when they heard these words, they swore unto him that they had never heard the proposal. And having summoned Cometes to convict them by his testimony, he said to him, 'Did I not send this message to them by you?' He answered, 'Yes, my lord.' 'And you told them,' said he. ' No, my lord,' he replied, 'I did not tell them, for I was afraid.' Upon this, in great wrath, he sentenced him to death; but subsequently said, 'Since thou hast been employed for both kingdoms, I will not slay thee.' But he commanded that both his eyes should be put out. And thus he spoiled the city of a vast and incalculable prey, and took the people captive, and emptied it of its inhabitants, and left in it a garrison of his own, and returned to his land with an immense 
booty of the silver and gold taken from the inhabitants, and the churches, and every where else. Its capture, and deliverance into the hands of the Assyrians d, took place seventy-two years, more or less, after the time of its first being founded by king Anastasius.

Nor was Dara the only place captured and VI.6. spoiled by Khosrun; for while he lay encamped before it, as he saw that no attempt was made to raise the siege, he sent a Marzban, named Adormahun, with a large body of troops, to besiege Apamea. On his march thither, Adormahun stormed numerous castles, which fell in his way, and rased and burnt them, together with several strong and well fortified towns, and at length arrived at Apamea. Now, upon a previous occasion, the Persian king, after capturing Antioch,

d The Persians, I imagine, are here called Assyrians, not because that country belonged to them, but in a biblical sense, as the type of the enemies of God's people. The capture of Dara was the greatest misfortune which for many years had befallen the Romans, and the news of it spread universal consternation throughout Constantinople, but it led to the one redeeming action of Justin's life ; for as it was now evident, even to himself, that abler hands than his own must guide the vessel of the state, he consented to appoint Tiberius as Cæsar. The fall of Dara occurred in A. D. 566 , and the account given by Theoph. Sim. iii. xi. agrees with our author. He says, 'o rov̂ Пє $\rho \sigma \iota k o \hat{v}$

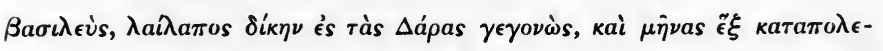

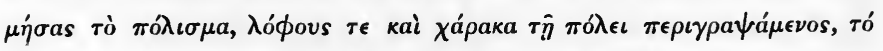

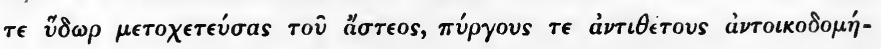

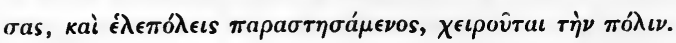

C c 
had once before laid siege to Apamea, and pressed it so hard, that finally it capitulated; and the king in person entered the walls, and was a spectator of an equestrian entertainment in the Hippodrome; and because he then destroyed none of the buildings, nor set fire to any thing, they now felt equal certainty that the Marzban on the present occasion would do them no harm. In this confidence, therefore, the princes of the city and the bishop went out to meet him, and carried him a dress of honour. And he treacherously said to them, "Inasmuch as your city is now ours, open unto me the gates, that I may enter in and inspect it.' And they trusting to him, and not expecting that he would do them any injury, opened the gates and admitted him within the walls. But no sooner had he entered than he seized the gates, and began to lay hands on and bind men and women, and spoil the city. And they brought out the prey, and all the people of the city, and put them outside the walls, and utterly spoiled Apamea, which yas full of the accumulated wealth of many years, and rich beyond most of the cities of the east; and when they had thus placed all the population, and the bishop with them, and all the booty outside the walls, they set fire to it, and burnt the whole of it from one end to the other. Having thus completed their work of destruction, they took with them their captives and the spoil both of Apamea and the other towns, and re- 
turned to the king, who was still sitting before Dara. And the captives were counted in the king's presence, and their number was two hundred and ninety-two thousand; and they were divided among the troops, and taken into the Persian territories. Shortly afterwards the king captured Dara, and spoiled it, and found in it immense wealth; for being regarded by all the neighbouring towns as impregnable e, they . had fled thither, carrying their valuables with them; and all this and the people he took, and carried with him into his land.

The next action recorded of the Persian moVI. 7 . narch is of a most tragic character; for being intoxicated with the glory he had gained in this expedition, and his mind elated by the greatness of the booty torn from the Roman territory, he gave orders that there should be selected from the captives two thousand virgins, full-grown, and of perfect beauty. And when they had been selected according to his orders, they were brought before him; and he commanded that they should be adorned in every thing like brides, in splendid and costly garments, and gold and silver, and jewels and pearls, and sent as a present to the barbarians who dwell in the heart

e Literally, 'as Beth Merda, which cannot be taken,' a name given in $\mathrm{r}$ Macc. i. 35 . ii. 45 , to the acropolis at Jerusalem, and translated in our version, 'a stronghold.' The Arabs also gave the same name to the citadel of Duma, which they regarded as impregnable. 
of his territories, and who are called Turks ${ }^{f}$, in order to please and content them, and hire their services. And when every thing had been done according to his command, and they were adorned magnificently, he appointed two Marzbans to form their escort, with a body of troops, and supplied them with large funds for their expenses, and sent them away, with strict injunctions that they should not be hurried on their journey, but travel quietly and at their leisure, that they might not grow thin, and lose their beauty. But these virgins being in deep grief, not only because of their separation from their fathers and brothers, and other relatives, but also because of their souls, which would be lost by their removal from Christian instruction; and their bodies, which were to be delivered into the savage hands of barbarians and enemies, with tears and bitter lamentations, spake one to another in their own tongue, as being now sisters; and all with one consent prayed for death instead of life. And their great grief was known to the other Syrian captives, natives of their own country, who were with the Marzbans, and to those also who were appointed to escort them, and attend to them: for they revealed to them in secret, as being natives of their own homes, their long-

f In the MS. the scribe has accidentally omitted their name, but from a comparison with the twenty-third chapter of this

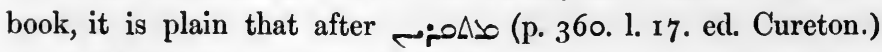
we ought to read cono; 
ings for death, as subsequently became known to every one, and was attested by their countrymen and compatriots. When then they had travelled to within fifty leagues of the barbarous people for whom they were intended, and learnt that they had reached the regions which were their final destination, it so happened that there came in their way a very broad and rapid river, which they found great difficulty in crossing. And as those who had charge of them had orders to give them rest, and not to hurry them, they encamped for a day upon the bank of this river. And here they all took counsel with one another, and in all there was but one and the same noble and courageous purpose, to despise death. They hastily therefore conferred with one another, and said, 'Let us all understand, that when, in company with the heathen, we have polluted ourselves with their heathen ways, and impure meats, and horseflesh, and things that have died or been strangled, and have lost our Christianity, we must still finally all die, and go to the judgment of doom. Whereas now we are all sisters, and Christians, and the daughters of Christian parents : let us not, then, separate from one another, but with one will and one soul and one mind, let us all firmly hold to one purpose, and before our bodies are defiled by the barbarians, and our souls polluted, and death finally overtake us, let us now, while our bodies are still pure, and our souls free from heathenism, in the Name, and trusting to the Name of our Lord Jesus Christ, offer unto Him in purity both 
our souls and bodies, by yielding ourselves up now to death, that we may be saved from our enemies, and live for evermore. For it is but the pain of a moment which we have to endure in defence of our Christianity, and for the preservation of our purity in body and in soul.' And upon these words, they all firmly united in one purpose and secret covenant; and having pledged themselves to one another by a solemn oath, they all in a body threw themselves into the river, and were drowned, and so escaped the hands of the barbarians: nor was there any one who did not cheerfully embrace this resolution. But as their keepers closely watched them, they kept their purpose secret, and waited for an opportunity; and as they were never left alone, they said, 'If you will grant us permission, we wish to wash on the banks of this river.' And as they had received orders to endeavour to please them, they gave them leave. But they said, 'We are ashamed to wash ourselves, if you stand by us, and look on: but if you will stand at a little distance from us, we can then wash.' And so they left them, and withdrew. And when they had all strengthened and encouraged one another, and all signed themselves in the Name of our Lord Jesus Christ, they threw themselves suddenly by one hasty rush into the river, and were drowned. And as the keepers watched the river, they saw some of them floating and carried down the stream on the surface in a mass, and others sinking: and on hurrying to the place where they had asked 
leave to wash, they saw not a single one of them alive. And, with bitter lamentations, they ran hither and thither, to save, if they could, but one of them, and were not able, nor could they rescue them. And thus these weak ones becoming strong in Christ in defence of their Christianity, committed their souls into the hand of God, that they might be saved in soul and body fiom the impurity and savageness of the barbarians.

The conquest of Dara and Apamea was followed VI. 8. by a truce of three years' duration, ignominiously purchased by the Romans for the sum of three talents. It extended, however, to Syria only : for in Armenia the war was continued on both sides. Now the cause of this war, which was the surrender of themselves by the inhabitants of the Greater or Persian Armenia to the Romans, has already been briefly detailed by us in our previous history: we will now therefore proceed with the events which followed the revolt. The Persian king, then, being hurried away by his vanity at the successful conquest of Dara, and deceived by the pride of his heart, and assured moreover by the truce just concluded, that he had no war to fear in Syria, assembled his army, and boldly invaded Armenia, with the purpose of investing Theodosiopolis, the border town, and thence penetrating to Casarea in Cappadocia, and thence onward to other cities: and so confident was he of success, that when Theodore the Silentiary was sent to him as ambassador, and noticed that he was upon the point of starting upon a military 
expedition, he made him go with him; and on his requesting to be allowed to depart, he said to him in derision, 'Come with me to Armenia, and we will together enter into Theodosiopolis, and there you shall bathe and refresh yourself, and then I will let you go.' And so he brought him with him into Armenia, being perfectly persuaded that without trouble he should capture the cityg. But when the Roman armies heard these things, although greatly terrified at the name of the king, they nevertheless made preparations for meeting him in the field: and when he saw how strong they were, he was greatly disturbed; for their number, as was said, was more than a hundred and twenty thousand men. When then they met him, and drew up in order for battle, he was alarmed, and would not give it, but marched toward another city. And they also hastened thither, and threw themselves in his way, and repulsed him from thence also. And as they had now made trial of his army, their own courage grew, and they despised him. And as he saw that matters were not advancing according to his wish, he marched towards the mountains on the northern frontier towards Cappadocia, with the intention of attacking Cresarea. But when the Roman armies saw this, they also marched

g An answer of Theodore, preserved by Menander, p. I60, is worth preserving. One day Khosrun boastfully asked him, if he imagined that a town like Theodosiopolis could resist the arms of the conqueror of Dara. But Theodore replied, 'Any town is impregnable which God guards.' 
thither, and arrived before him, and posted themselves in his way, and met him in the mountains of Cappadocia, and stopped his further progress, and would not let him pass over. And there they encamped opposite one another for several days, nor would he venture to engage with them in a general battle. And when he saw that they were more numerous and powerful than himself, and that he could not pass by them, and march upon Casarea, he was greatly disturbed and alarmed, and began to plan how he might, if possible, effect his escape to his own land. But his Magian priests blamed him, and dissuaded him from this course, and at their instigation he wheeled round, and leaving Cappadocia, advanced to attack Sebaste; for though terrified as well as his men at the Roman armies, yet from shame of being ridiculed for not having accomplished any of his plans, he attacked and burned Sebaste with fire. But he could take neither booty nor captives, because the whole land had fled from before him. Crossing next from thence, he began to retreat towards the East, in the hope, if possible, of escaping homewards. But the Roman armies now despised him; for having tried the mettle of his troops, they had learnt to regard them with contempt, and were eager for battle. And when he saw that they had surrounded him, and were pressing upon him on all sides, he was compelled to flee in haste to the mountains, leaving behind him his camp, and all his equipage, that is, his tent, and retinue, and tent-furniture of silver and 
gold and pearls, and all his magnificent garments of state, and fleeing away empty. And the Romans hastened, and entered his camp, and took possession of it, and slew every one whom they found there, and laid hands upon his equipage, and that of his nobles; and also upon the fire-temple in which he used to worship, and upon the horses which drew it, and were harnessed to it. And the wealth gained from spoiling the king's baggage was so great, that the Roman soldiers who had found it deserted with their gains in a body, and were never heard of nor seen afterwards. As for the Persians who had charge of it, such as managed to escape, went weeping to the king, and said, 'My lord, the Romans fell upon us, and have slain most of thy servants, and spoiled and plundered all thy camp.' And when he heard this, he answered, 'Let them alone:' and gave orders that his whole army should gather round him, and set up for him a wall of shields; and he made them stand in their ranks, and riding through on horseback, he supplicated them, pointing to his gray hair, and saying, 'My brothers, and children, have pity upon my gray hair, and advance and fight for the kingdom of the Persians, that it may not be despised and ridiculed : See, I, on horseback, will fight along with you as an ordinary trooper.' For his own princes were constantly contending with him, saying, 'Whether we live or die, Persia will get an ill name by us. For never at any time has any Persian king done what you have done, and brought 
us here to die among these mountains.' This conversation, and the previous events, the Romans learnt subsequently from these persons themselves. The Persians consequently made their preparations, and descended on the opposite side, with the view of fleeing ${ }^{\mathrm{h}}$ to some city, and advanced towards Melitene: and had it not been for the envy and divisions which existed among the Roman generals, and prevented their acting in unison, they might utterly have destroyed both him and his army: for all that was necessary for this was, that they should arrange a common plan of operations, and with their several divisions surround him. As it was, the Persians advanced against Justinian the patrician, the son of Germanus; and Justinian was afraid, and fled from the encounter: and his fellow generals did not join him, nor come to his support. And when the king and his army saw this, they took courage, and were emboldened to attack and set fire to the city of Melitene.

But the real object of Khosrun was chiefly to VI. 9 . escape: and as soon, therefore, as he had destroyed Melitene, he directed his march towards the Euphrates, in the hope of making good his retreat to his own land. But upon hearing this, the Roman generals wrote to him as follows: ' The deed thou hast accomplished in invading

h Instead of 'دلخ:, ' that they might flee to some city,' the right reading possibly is 'بـes? ' that they might destroy some city,' their object being to recover their honour before retreating homewards. 
our territories, and burning a city, is not in accordance with the rank of a king - to do forsooth a piece of mischief ${ }^{i}$, and beat a retreat. Even we, who are but the servants of a king, had we acted as thou hast done, it had been a disgrace to us: and how much more to thee, who art not merely a king, but, as thou accountest, even a king of kings. For it becomes not a king to emulate the deeds of those who come in thievish fashion to rob and run away, and set on fire and burn: rather it is a king's way, in the open light to stand up in battle mightily and boldly and royally: and should he conquer, then let him glory as a king in victory, but let him not enter like a robber, and destroy, and steal, and run away. Prepare thyself, therefore, and let us at length stand up in battle with one another in open fight, that it may be plainly known with whom both the victory and the defeat remains.' And when the king heard these things, he gave orders for battle the next day, in a plain to the east of the city, at some little distance from it. And in the morning the two sides approached one another in battle array, until but a small interval separated them: and there they stood in their ranks facing one another from morning until the sixth hour, and not a man moved from his place, the king himself being posted in the rear of his army: and so they stood looking at

i I imagine / | be, 'to act piecemeal,' ' on a petty, nibbling scale,' like one breaking off small fragments. 
each other, and waiting to see who would begin the fight. And those who gave me this account, with the strongest asseverations of its truth, and who were the officials appointed to act as interpreters between the Romans and the Persians, said, 'At length three of us spurred our horses, and sprang forth fiom the Roman ranks into the space between the two armies, and went at full speed close up to the Persian ranks, and wheeling round returned at full speed: and this we did three times, without being attacked by them, riding as fast as our horses could carry us, while both sides watched us intently, as our object was to provoke them to battle. But not a man moved from his place, or came out against us, but they stood still like a wall in their ranks.' And no message passed between either army, until finally Khosrun sent to say, "There can now be no battle to-day: for the time has passed:' and so the two armies parted for the present. But during the night, before the day dawned, the king and his army made for the Euphrates, in the hope, by using every exertion, of crossing the river, which is six miles distant from Melitene: but the Romans were upon his track, purposing to drive him into the river, and destroy him. And in this they were successful: for their rapid march had thrown the Persians into confusion; and at the sight of the Roman army pressing close upon them, they hurried on horseback into the river, and more than half the army sank there, and were drowned. But the 
king himself and the rest with difficulty swam over to the other side on their horses, and escaped, and marched rapidly into the Roman Armenia: and as they hastened along, he gave orders to set fire to all the villages which came in their way. And thus finally he reached the lofty mountains of Carkh ${ }^{\mathrm{k}}$, where never yet had road been: and he was compelled to make his army advance before him, and construct a road, cutting through forests, and occasionally, in order to open a path, they had to dig through rocks, and hew the stones away: and in this manner, vexed and anxious in mind, he scarce escaped from the hands of the Romans, and arrived in his dominions in great distress: and there he published an ordinance, and made a law, that the king henceforth should not go out in person to war, except against another king ${ }^{1}$.

VI. г. Success had now for some time attended the Roman arms, and their generals had gained great glory in many important victories, and had vanquished all who were sent to oppose their progress: they had also captured and subdued the northern tribes, who previously had been subject to the Persians, and further carried their de-

k The reading probably ought to be $\mid \omega$ ?: 0 , as the mountains of Kardaikh must be meant, Khosrun's route being through the Lesser Armenia, and, as Theophylact tells us, Arzanene. The difficulties of these mountains we already know from Xenophon's account of the passage of them by the ten thousand.

I Theophylact, iii. I 4, also mentions this law, and is ridiculed by Gibbon for giving credit to it, but apparently without reason. 
vastations for many scores of leagues into the enemy's dominions, and penetrated within a hundred miles of his capital, spoiling every thing in their way, and especially carrying off the elephants, until they had filled Constantinople with these animals. The full account of their successes would exceed the limits of our history, but all Persia trembled before them. When however, in the year 880 of Alexander, (A. D. $577^{\mathrm{m}}$,) the Persian king withdrew to his dominions, the Romans laid all care aside, and were elated with pride, as men who had valiantly withstood the king in person. Henceforward they acted as though they had nothing to fear, and imagined that now at length they were finally delivered, and at rest from all wars and conflicts. And similarly the troops in their camps were full of over-confidence, and carelessness, and had put off their arms, and sent their horses away to pasture, when suddenly their outposts came in, and said, 'Arise, and arm yourselves: for the Persian army is upon you, with the Marzban Tam Khosrun ${ }^{n}$ : look to yourselves.' But they ridiculed the idea, and said, contemptuously, 'Do you think they would venture to come and find us, and show themselves

$\mathrm{m}$ Menander puts this event in the autumn of 576 .

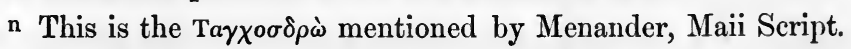
Vet. Nov. Col. ii. $3^{6}$, where we learn that he met with a mortal wound from some unknown hand: upon which Menander frigidly remarks, that there was nothing very wonderful in this, ' for chance rules such things.' 
to us?' And they paid no attention, nor troubled themselves to get ready; so that, as my informants said, the Persian army was upon them, when they were not only not prepared for battle, but not ready even to show their faces. When then they saw them approaching in long files, firm as a wall, a panic and terror fell upon them all alike, and confusion: for they had not brought in their horses, and were occupied solely with eating and drinking and gluttony: and some were here, and some there. And as each one caught sight of the enemy, he was terrorstricken, and began to flee at full speed: and others caught the infection, and fled, because their comrades fled: and the generals, when they saw themselves left alone, and that their troops were in full flight, fled too: and he who could get his arms, and catch his horse, mounted, and rode away; and he who could not catch his horse, fled away on foot, carrying his arms at first, but when he grew tired with running, he threw them away upon the road, and fled weaponless. And some even of those who were mounted, and had their arms with them, on growing tired, threw them away; or if their horse grew weary, they dismounted, and fled away on foot. As for the Persians, they followed them at their leisure, not so much pursuing after them, as jesting and ridiculing and laughing at them, because when they were a hundred and twenty thousand in number, while they themselves were not more than thirty. thousand, they 
were thus panic-stricken and fled away, though they had not been terrified nor fled from their king. And thus at last, shame and an ill name fastened upon all the Roman armies, with their commanders; for the Persians did not so much as draw sword against them, nor bend the bow, nor shoot a single arrow, but gathered up the arms and coats of mail, which they had scattered in their flight, and their breastplates, and shields, and helmets, and spears and swords, and lances and bows, and quivers full of arrows, beyond numbering. And the cause of their defeat, as all men said, was, that the Romans had made God angry: for when they entered the northern territories of the Persian realm, where the people are all Christians, and the priests went out to meet them, carrying the Gospel, and bearing crosses, they paid them not the slightest reverence: and finally, in impious sport, they even went so far as to seize hold of little children, of one and two years of age, and, taking them one by one leg, and another by the other, threw them as high up in the air as they could, and then caught them as they fell on their spears and swords, and running them through, cast them to their dogs. Nor did they confine their cruelty to children, but treated the monks also with contempt, and slew and plundered them: and still more, they dragged out of their retirement the hermits, men of great age, and highly esteemed, who had practised asceticism for many years, and hung them up, and tortured them,

D d 
and mutilated them with their swords, saying, 'Bring us gold and silver:' And the nuns they tortured in a similar manner, even till they died miserably from their cruelty. And as was generally said, it was because of these atrocious deeds, by which they had made God angry, that He put them to shame, and brake them before their enemies, nor could they stand up against them.

When such were the excesses allowed by the lax discipline of the Roman camp, it is no wonder if Armenia began to grow weary of its defenders, and willingly made terms again with the

VI. ir. Persians. Our historian, therefore, after referring to his previous history for an account of the rising of Armenia, and of the journey of the Catholicus of Dovin to Constantinople, and his magnificent reception there, and that of the nobles who accompanied him, now tells us, that after the king of the Romans had undergone all these conflicts with the Persians in their defence, being unwilling to abandon those who, for the sake of Christianity, had sought refuge with him; and had further, so to say, enriched all the Armenians with gifts and magnificent presents, and granted them an immunity from taxation for three years; and when the Persian sent to him, saying, 'Give me up my slaves who have rebelled against me,' had refused to consent: after all this, when finally the Persian had recourse to artifice, and promised the Armenians in writing not to do them any evil, nor remember their 
offence against him, they then all deserted the Roman side, and the whole country delivered itself up to him, except those princes who had taken refuge with the king at Constantinople. Omitting them, the number of those who surrendered was twenty thousand men, and the government of the Persian king was restored there as of old. Of those who stayed at Constantinople, the leading men were Vardun with his retinue, and the king of a tribe who also had come over to the Romans, and whose name was Gorgonis; and both were still treated with great honour, because they had come for refuge, and surrendered themselves to king Justin, in the fifth year of his reign, which was the year of Alexander 882 (A. D. 571). The war, however, upon their account lasted for several years afterwards.

Attempts, however, were made from time to VI. 12. time to bring about a peace, and in the year 887 (A. D. 576) three members of the senate were sent to the borders as ambassadors, whose names were Theodore the Patrician, the son of Peter Magister ${ }^{\circ}$, and John and Peter, who were both of consular rank and of the family of king Anastasius, and Zacharias, a physician of Arx Romanorum and a learned man, went with them. On the Persian side came Mabodes and others; and the place appointed for their meeting was near Dara, which the Persians occupied; and their

o The Magister, or, more fully, Magister officiorum, was one of the chief dignitaries in the emperor's household.

D d 2 
instructions were to inquire into and settle the matters in dispute between the two states, as each side accused the other of misconduct, saying, "Ye transgressed what was fitting in such and such matters.' And especially they each threw upon the other the blame of having violated the peace, the one side saying, 'Ye were the first to break it, by crossing our borders and devastating our land;' while the other replied, 'No; it was your Arabs who first crossed and wasted our territories.' And thus they remained, coming to no conclusion, but stirring up grounds of quarrel and dispute, till they even proceeded so far as to personal altercations and insults. And in this way they spent a year and more in debate with one another, each side sending reports to their own sovereign, which, because of the illness of king Justin, the godloving Cæsar Tiberius received at Constantinople, and answered; and while both sides were anxious for peace, neither would humble itself to the other, nor acknowledge its weakness; and consequently they confronted one another with the appearance of determination. For the Roman Cæsar sent to the Persians, saying, 'We rejoice in peace far more than in war; and if you wish for peace, we will not hold back : but if you wish for war, we shall not prove less brave than you are, but are ready to meet you.' But the Persian supposed, that because three talents of gold had been given him as the price of peace for three years, he might now look for a talent as yearly tribute in 
return for his consent to a treaty. But when the Cæsar knew this, he sent in answer, 'You are greatly mistaken if you imagine that the Roman realm will give you a single pound as the price of peace, or will purchase peace with gold at all. If, therefore, you wish that the two kingdoms should make peace with one another on equal terms, well and good; but if not, you will have war.' And when the Persian learnt that this was his decision, he was not a little alarmed, and consented that a peace on equal terms should be made without gold. And when the Cæesar received this answer, he wrote back in return, 'Know for certain that the Roman realm is no paltry state, but has ever been a powerful empire, and owed subjection to no one: nor can I tell for what reason the kings my predecessors submitted to give to the Persians a yearly sum of five talents of gold. Learn, therefore, that neither to you nor to any other will the Roman realm henceforward for ever give as much as five pounds. For your ambassadors were so arrogant as to say to the barbarous tribe called Turks, "The Romans are our slaves, and as despicable slaves, pay us tribute." If, therefore, you do not abandon this payment, there can be no peace between us.' And though he had already surrendered much, yet he not merely immediately consented, but ordered the payments to be discontinued; and had copies made in writing of the conditions of peace, and sent them to the borders to the ambassadors. And when the 
Cæsar saw that he had submitted to these terms, he further sent to him, 'Give us up at once the city of Dara, and we will make peace.' And when the Persian received this message, he was greatly disturbed, and wrote, 'Dara I took by the laws of war; but you did not take the lands of our slaves the Armenians by war, and yet you retain them. Give me back Armenia, and I will give you back Dara.' But the Cæsar could not bear the idea of surrendering the Armenians, because they were Christians, and had therefore given themselves up to the kingdom which represented Christendom; and therefore upon this point the ambassadors of the two powers had so violent a quarrel with one another, that they put on their arms, and were ready to meet in battle. Thus, then, they separated from one another, in mutual displeasure, and the negotiations were broken off, and both realms prepared for war. And the Persian ambassador sent for the military commanders, and gave them orders, saying, 'Go, and take measures for the safety of the marches, as we shall not make peace with the Romans.'

VI. I3. But the Persians not only took measures for their defence, but also invaded the Roman territories: for there had been present at the conferences a powerful Marzban, named Adormahun ${ }^{\mathrm{p}}$; and no sooner were the negotiations broken off, than being enraged at some reproaches addressed

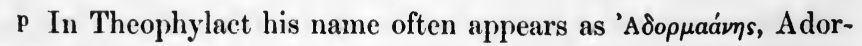
manes. 
by the ambassadors to himself, he collected his troops, and began to waste and burn every thing on which he could lay hands, in the districts round the strong towns of Dara, and Telaq, and Telbesme, and Resaina, sparing neither churches nor monasteries, nor any thing throughout the land. And thus he wasted and burnt and slew as far as Tela; to the inhabitants of which town he sent, saying, ' Deliver unto us your city, lest the same fate happen to you as to the people of Dara, and ye perish. For where now are your ambassadors who were threatening us? Let them come hither, and attack us.' But the people of Tela answered, 'We cannot surrender our town to you, for we have received letters, with the intelligence that the patrician Justinian is already on his march, and has with him sixty thousand

q Tela, or Tela Mauzalat, otherwise called Constantina, in honour of the emperor Constantine, who rebuilt it in A. D. 350, was situated about fifty-five miles due east of Edessa. Of Telbesme little is known: Asseman mentions a defeat of the Romans there in A. D. $5^{\circ} 3$, and in B. O. ii. I I commemorates the building of a monastery on a mountain at Telbesme by Athanasius, bishop of Maipheracta; to which he again refers in p. 228, and adds, that it was one of five Mesopotamian towns in which John, bishop of Marde, erected magnificent churches of stone and lime. Resaina, otherwise called Callirhoe, and Theodosiopolis, lay about seventy miles to the south-east of Edessa, and was one of the most considerable cities of Mesopotamia. It had its name from Theodosius the Great, who restored it in A. D. $38 \mathrm{I}$; but it was not till A. D. 506 that Anastasius followed his policy of protecting Mesopotamia by powerful fortifications, and built Dara, which for half a century was the bulwark of the Roman empire in those regions, and called, after its founder, Anastasiopolis. 
Lombards: and were we now to surrender ourselves to you, he would come, and utterly exterminate us from the land.' Upon hearing this, the Persians withdrew, but not till they had burnt the great and magnificent temple of the Mother of God, which stood outside the city ; and having done whatever other mischief they could, they retreated to Dara. And the Marzban derided the Romans, and was greatly elated at the devastation he had wrought, and the captives he had taken, and the great booty which his men had carried off.

VI. 14. As the Roman reverses in the East had arisen from the want of a good understanding among the generals, who carried their quarrels by letter even into the Cæesar's presence, he determined to send thither an officer of his own court, whose name was Maurice, and who held the same post which he had himself possessed before he was made Cæsar, being Comes excubitorum, or count of the body-guard, for which reason he is generally known by the name of the Count Maurice. Having summoned him, therefore, he gave him orders to proceed to the East as commander-in-chief of all the forces there, with authority to govern and direct and control all the generals and tribunes of the whole army, and that no one should venture, on any pretext, to transgress his orders and the word of his mouth. And further, he gave him power to appoint and to dismiss any officer from the service at his sole discretion; and sent with him many talents to provision the troops, having 
also just previously commissioned Gregory the prefect of the Prætorian guards-a man who had distinguished himself in all the affairs of Armenia-to proceed thither to administer and take charge of the sums of money disbursed for the army.

No sooner then had the illustrious Maurice received his orders, than he set out on his journey, and arrived first in Cappadocia; where he began to collect troops; and numerous Romans, and excubitores, and officials ${ }^{r}$, and common soldiers had accompanied him from the capital to enlist under his standard, which was now joined by hosts of Iberian and Syrian recruits. Directly then that he had gathered an army, he marched forward and encamped between Armenia and Syria, at the town of Citharizon: and there he assembled all the generals, and conferred with them, and appointed them their posts, and gave them their orders, and encouraged them, and sent them away. And for two months he remained there, and his name spread abroad, and fear fell upon all the Persians, who saw that the Roman armies were more numerous and more powerful than themselves. Being afraid then of meeting them in open battle, they contrived a stratagem, and while their real object of attack was that part of Armenia which borders upon Persia, they sent to the inhabitants of Theodosio-

r John of Ephesus especially mentions the scribones, whose duties have been explained above. 
polis ${ }^{\mathrm{s}}$ the following message: 'After thirty days, be ready, and meet us in battle.' And when the Romans received this message, they sent to inform the count Maurice, who immediately gave orders that his whole force should get ready for the encounter. But the Persians, immediately that they had sent the message, the object of which was to deceive the Romans, put their stratagem into execution, and made their preparations, and gathered their forces, and crossed over into their territories, making their inroad unawares at a place near Maipherkatt. And as soon as they had entered the Roman territory, they began to devastate and burn all the land of Sophene, and especially the churches and monasteries: and in the same way they treated the district of Amid; and on approaching the town itself, they burnt all its suburbs, up to its very walls, and destroyed every church, and the large monasteries situated there. And for three days they besieged the city; but when they saw that they could not take it by storm, and were afraid lest Maurice should come upon them with his army

s That is, Resaina.

t This place, better known as Martyropolis and Tagrit, was on a ford of the Euphrates in Sophene; to Syriac scholars it has the additional interest that most of the MSS. brought from the Nitrian deserts were collected in its neighbourhood, and bear its name on the fly-leaves. At Amid our author was himself born, and naturally therefore he took great interest in this region, and probably had more than ordinarily good means of information as to every thing that befell it. 
and put them to the sword, they raised the siege, and resumed their devastations, burning and spoiling the whole land of Mesopotamia like thieves, and finally wheeling round, retreated into their own country. And thus, while the Romans were preparing for the day appointed for battle, the Persians deceived them, and, like thieves and robbers, invaded and burnt and wasted and spoiled the whole of Mesopotamia. The date of this invasion was the year of Alexander 888 (A. D. 577), being the same as that on which Maurice had travelled thither from the capital: and the time spent by them in this rapid raid, and their hurried flight back to their own land, was eighteen days.

On hearing of this inroad, the Count Maurice VI. I 5. was very indignant; and gathering his whole force, marched into Arzun w, a fertile province of Persia, in great anger at having been mocked and made the laughingstock of the Persians. And on entering it, they wasted and overthrew all that came in their way, and took a great booty, and advanced victoriously as far as the Tigris, burning and destroying the whole country as they went. But because the inhabitants were true Christians without guile, they came out to meet the armies and generals, with the holy vessels and crosses and the gospel, asking of them a pledge for their lives, and saying, ' Have mercy

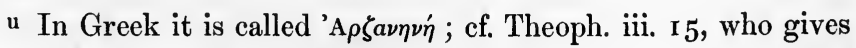
a short account of this invasion. 
upon us; for we are Christians like you, and ready to serve the Christian king.' And when Maurice and the rest heard these appeals repeatedly addressed to them, they shewed them mercy, and said, "Whoever of you wishes to live, and serve the Christian king, let him bring hither his goods, and load all that he has upon his horse, and he shall live, and we will not slay him : but if we find him here after two or three days, he shall die.' And so the great majority of the people of Arzun, whosoever had escaped from the sword, fled into the Roman territory. And when the news was carried to the king, he gave orders for them to be sent to the island of $\mathrm{Cy}$ prus; and they had lands allotted them among all the villages throughout Cyprus, and dwelt there. As for the Persians, who stole into the Roman territories, and made a rapid raid there, being afraid of Maurice, lest he should overtake them, after plundering and burning as much as they could for fifteen ${ }^{x}$ days, they fled back, and retired into their own land.

Of the proceedings of Maurice in the two following years, our author has given us no account; but in A. D. 580 he made, in company with the Arab Mondir, the unsuccessful expedition against Persia, to which we have already

$\mathrm{x}$ There is a slight discrepancy in the numbers, as in the previous chapter John informs us that they consumed eighteen days in their inroad. In the twenty-seventh chapter, however, he again fixes the period at fifteen days, and also in the thirtyfourth. 
referred, and which led to Mondir being delivered into the hands of the Romans by the treachery of his patron Magnus.

The narrative of the expedition here given by John is as follows: 'At a subsequent time Mau- VI. i6. rice and Mondir the son of Harith king of the Arabs united their forces together, and marched into the Persian territories by the route through the desert, and penetrated into the enemy's dominions for a distance of many score leagues, as far as Armenia. But on arriving at the great bridge there, upon which they had relied for crossing over, and subduing the wealthy cities upon the opposite side, they found it cut away: for when the Persians had learnt their intentions, they had destroyed it. And as they and their armies had undergone great fatigues, especially the Romans, they came to high words with one another, but nothing could be done except to return, without having met with any success; and it was with difficulty, and only after great fatigues, that they finally arrived back in safety in the Roman dominions. As both were equally irritated, they wrote angry accusations against one another to the king; for Maurice thought that Mondir had sent information of their plans to the Persians, and had thus enabled them to break down the bridge to prevent his passage - a supposition which was false. And the king, before he could reconcile Maurice and Mondir with one another, had great difficulty, and was obliged to request the mediation of many of the leading men. And 
finally Maurice went to the king at Constantinople, but whether or not he there accused Mondir is not known for certain.

VI. I7. No sooner had Maurice and Mondir returned to their respective territories, and the Persians saw that their own land was free from the invading army, than their Marzban, Adormahun, with a large force, crossed over into the Roman province, and entering the districts of Tela and Resaina, destroyed and burnt whatever he had left in his former invasion. Thence he marched into the fertile district of Edessa, and ravaged the whole province of Osrhoene, passing hither and thither in full confidence without fear, as though he were dwelling in his own land. And he continued there many days, not leaving so much as a house standing wherever he marched, and making sport of the whole Roman army, because they were not able to drive him away. Soon after, when Maurice and Mondir returned from the Persian territories, wearied with the fatigues of the journey, and he learnt that they purposed to attack him, he sent to them in derision, saying, "Inasmuch as I have heard that you propose to fall upon me, do not trouble yourselves to come; for you are exhausted with the fatigues of your march. Rest yourselves, therefore, a little, and I will come to you.' And after wasting and spoiling and capturing and doing whatever he liked, on hearing that they intended to attack him, he took with him all his booty and his captives, and withdrew from the 
Roman territories, and arrived in his own land without a single man attempting to drive him back of the two hundred thousand Romans who were eating at the king's expense; nor was it till he had made up his mind to retreat that they commenced their march; and when they could not overtake him, they said that he had fled too fast.

In Mondir, however, the Persians found a more VI. I8. active enemy than in Maurice; for when the Arabs under their rule had gathered their whole force, and been joined also by a division of the Persian army, they set out, intending to fall upon Mondir, and take vengeance upon him for having invaded their territories. But the warlike Arab, on hearing of their purpose, determined to lose no time, but gathered his troops, and set out to meet them in the desert. And having learnt by his spies where and how many they were, he fell upon them suddenly, when they were not aware of his approach; and in their alarm and confusion he put some to the sword, and destroyed them, and others he took prisoners, and bound, so that but few of them escaped. And thence he marched directly upon Hirah, and pillaged and burnt it ; and so returned with great booty and numerous prisoners and surpassing glory.

The prisoners whom the Persians had taken VI. rg. in Dara and Apamea, and the other cities which they had conquered, were counted in the king's presence at Nisibis, and found to be two hundred 
and seventy-five thousand. And such of them as were not there and then divided among the troops, were shut up in Antioch, a city which Khosrun had built in his own dominions in honour of his having captured and spoiled the famous city of that name; and there he confined all those whom he had taken captive in Antioch, and in all the country round about, as well as the inhabitants of Dara and Apamea, and the places of which he had subsequently made himself master. But though confined and watched by a strong garrison, they did not desist from schemes and conspiracies, in the hope that something might be done to help them. They secretly plotted, therefore, with one of the Persians who guarded them and kept the walls, and prevailed upon him by a bribe of five hundred drachmæ, which they collected among them, to let two of them down by night by a rope from that part of the wall where he was sentinel. The men selected were two pious monks, both Arabs, whose names were, of the first, Benjamin, and of the second, who was his disciple, Samuel ; and their plan was, if they escaped thence in safety, at once to go to the king of the Romans, and tell him how many thousand captives were shut up in Antioch. And they all sent a message to him by their hands, saying, 'Lo, we are shut up here to the number of more than thirty thousand men; and the Persians who guard us are not more than five hundred: if, therefore, but one Roman general be sent, and show himself 
outside the walls, we will slay the Persians, and break out of the city, and return in safety to the Roman territories.' And when this message had been intrusted in secret to the blessed Benjamin by the captives, the Persian who had received the bribe let him and his companion down by night from the wall with cords, and they fled away, and arrived safely in the Roman dominions. And he delivered his message first to the Roman generals, and they sent him on with letters to the king. And on his arrival at the capital, he came unto me; and having delivered his message to the Magister, he went and informed the king Tiberius. But he paid it no attention, and acted as though he thought it was not true; and so the deliverance of all these oppressed captives was deferred and nothing done.

There may perhaps be nothing improper, VI. 20. though we are writing of a Magian and an enemy, in giving an account of the life and death of Khosrun, king of Persia. As the facts then themselves prove, he was a prudent and wise man, and all his lifetime he assiduously devoted himself to the perusal of philosophical works. And, as was said, he took pains to collect the religious books of all creeds, and read and studied them, that he might learn which were true and wise, and which were foolish and full of absurdities and empty fables. And after the perusal and study of them all, he praised the books of the Christians above all others, and said, "These are true and wise above those of 
any other religion.' And on this account he the more constantly studied and read them, and believed their words: nor did he ever show himself an enemy of the Christians, and though incited by the Magians against them, he was not often prevailed upon to consent to their being persecuted. Moreover, on one occasion the Catholicus of the Nestorians, who was constantly at his court, accused before him the few orthodox bishops to be found in Persia: for the bishops generally throughout the whole country are Nestorians, and but few orthodox are found there. As then the Catholicus had brought serious charges against them, the king commanded them to assemble in his presence, and hold a discussion upon their faith, that he too might know and examine, in his own person, what was said, both on the one side and the other, and decide, after hearing their arguments, which were most in accordance with reason. And when the orthodox had arrived, he commanded that both sides should assemble, and enter into his presence: and on doing so, they were placed on opposite sides before him, the chief of the orthodox being a certain holy bishop, named Achudemes. And the king commanded them to argue and debate with one another as to their faith, upon which the Catholicus and his side began, while the orthodox waited until he had concluded his discourse, to which they then replied, and disproved all his reasonings, and refuted him, having the king himself for judge. 
As however the arguments brought forward upon the two sides were lengthy, and not easy to write down, we must omit them. The king Khosrun, however, approved and praised what had been spoken by the orthodox, and said to the Catholicus, 'These men know what they say, and can establish and prove their words, and their arguments seem to me to be very true: but yours are confused and indistinct, and have no solid foundation; nor do ye yourselves seem able to prove your words; nor, in fact, do they seem to me to have any certainty and truth, like those spoken on the other side. And from this I perceive that you have accused them before me without just and fitting cause; and now that I have myself seen and heard them, I command that ye never again offend against them, nor do them wrong.' And when he had uttered this command, all the orthodox fell down, and made obeisance to him, and thanked him, saying, 'Lord, they persecute us, and fall upon us, and spoil us, and uproot our churches and monasteries, and do not permit us to offer up in them our prayers and supplications unto God, that He would establish and watch over your life, and the welfare of your kingdom.' Upon which he comforted them, and bade them go and build their churches and monasteries: 'for no one,' said he, 'henceforth shall be permitted to injure you.' And thus having worshipped him, and prayed for him, they returned to their homes with great joy: and henceforward all the orE e 2 
thodox in the Persian dominions dwelt there in great confidence and fearlessness, so as even to venture, after having received this commandment, upon doing a great act, which was no less than the setting up of a Catholicus of their own, by the hands of the blessed lord Jacob, the bishop of the orthodox, a thing which had never been done before in the Persian dominions : but from that time even until this day there has continued to be a Catholicus of the believers in Persia $\%$.

VI. 2 r. It appears also that the war between Persia and the Romans was a cause of great grief to him, and that he would readily have submitted to much for the purpose of reestablishing peace. And in testifying to this, let not men imagine that our purpose in giving this short history is to write a panegyric upon a Magian, though he was one in whom Samson's riddle came true, 'That out of the eater came forth meat, and out of the bitter came forth sweetness.' For what other epithet than bitter can we apply to a man who was wandering in heathen error? Still, our purpose in recording his history is simply to throw light upon the events which we have detailed above. When then the peace upon the

y The first Catholicus, or Maphrian, was the very Achudemes mentioned above, as the chief speaker at the discussion with the Nestorians. His consecration took place A. D. 559, and sixteen years afterwards he was beheaded by Khosrun for baptizing a boy of the royal race: cf. Ass. B. O. ii. 441. 448 : Le Quien, Or. Christ. ii. I 533 . 
marches was broken, he showed that he was vexed and grieved thereby; and even, as was said, when he was marching against Dara, the parchments on which were inscribed the terms of the peace, which had been made between the two empires, were carried before him, tied up and suspended towards heaven: while he himself said, 'Thou, $O$ great God, Who knowest all things, behold, I pray, that I neither have wished, nor now wish, for this devastation and shedding of human blood, which is taking place between the two kingdoms.' And he gave further proof of his desire for peace, when his end was nigh, by his readiness to make concessions. For he had imagined that he should receive a talent of gold for every year of the peace, as had been the case in the three years which had just elapsed. But when the ambassadors of the Romans and Persians met upon the borders to treat and confer about terms, the victorious Tiberius, as we have mentioned above, being then Coesar in the lifetime of Justin, and all the Persians afraid of him, behaved himself manfully, and stood up, saying, "The Roman realm is no abject state, nor in subjection to the kingdom of the Persians, nor will we give you a single talent in order that there may be peace. And if peace be not made on equal terms, I will never make peace with you at all for ever.' And this not a little alarmed the Persian king, and he assembled his Magians together, and said unto them, - We learn that the Casar of the Romans is a 
young and warlike man; and I, as ye see, have grown old, and can no longer bear the fatigue of wars. Let us therefore make peace with the Romans, for we cannot overcome them.' And so they conferred together, and sent the following answer: "That ye may not imagine that I look to gold alone, and prefer gold to peace, lo! now let us make peace on equal terms for both kingdoms, and put an end to the devastation at present going on; nor do I ask for any thing.' But no sooner had he assented to this, than the victorious Cæsar Tiberius threw upon him a second slight, saying, 'Do not imagine that of the gold which up to this time you have received from the Roman territories, you will ever receive again to the extent of a single drachm: for the Roman realm is not so weak as to pay tribute to the Persians.' To this the Persian sent in answer, "The yearly subsidy of gold was settled by the kings who preceded you, nor had you any thing to do with the arrangement: but know, that peace is far dearer to me than any thing whatsoever, and therefore I remit these talents also, and let us make peace.' $\quad \Lambda$ nd when the Cresar saw that the Persian gave way, and consented to these things, he sent him a further message, saying, "If you will not give up Dara to us, we will not make peace with you.' And at this the Persians were irritated, and the peace broken off, and they separated at the marches in so hot a quarrel, as even to put on their arms in readiness for combat with one 
another. And immediately the work of devastation was resumed in both states. And just then at that very time Khosrun the king died, in the year 890, (A. D. 579,) and was succeeded by his son, after a reign, as they reckon, of forty-eight years.

The name of the new king was Hormuzd, and VI. 22. his character was very different from that of his father. For as the reports of him show, and facts themselves prove, he was a ferocious and savage youth, and but slightly endowed with understanding. At the commencement of his reign, being proud and deficient in sense, he was so haughty and arrogant, as not even to send to the king of the Romans the usual symbols of his having succeeded to the throne, according to the custom of kings. For when Tiberius was appointed Casar, although the two realms were at feud and war, he did not depart from the established usage of sending the customary marks of respect; but one of his first acts after ascending the throne was to despatch presents to Khosrun as the symbol of his having commenced his reign, just as Khosrun, when he came to the throne, had done to king Justinian, whose reign began three years before his own. But this man, in his senselessness, haughtily said, "Why should I send gifts of honour to my slaves?' And accordingly he did not send them. Nor was this his only act of the kind. For certain Roman ambassadors had been sent to his father with presents and royal letters, but on their arrival at 
Antioch, had learnt that Khosrun was dead, and that his son reigned in his stead. But when our peace-loving sovereigns heard of it, they commanded the ambassadors to continue their journey, and carry the presents to the new king. But though he had given them permission in a haughty manner to enter his realm, nevertheless he received them with insult, and illtreated them, and threw them into prison, where he left them for a long time to languish in misery, till they were ready to perish and their lives be consumed. But at length, on the advice of the Magians, he let them go; but even then he would not permit them to travel by the direct road, but sent persons with them, with orders to take them over lofty and precipitous mountains, in the expectation that they would be worn out by the difficulties of the way, and die: so that they even said to the escort, "If you wish to kill us, why do you not openly slay us at once, instead of bringing us here to die of fatigue among these mountains?' But the aid of God was with them, and brought them back in safety: and they related, both to the king and men generally, these proofs of the Persian's ferocity and want of sense.

Our historian has on several occasions referred to a barbarous tribe, called Turks, who dwelt in the heart of the king of Persia's dominions ; and now he informs us, that they also were indirectly the occasion of the war breaking out between the

VI. 23. Romans and Persians. For the first cause, he says, why the peace was broken was, that the 
Persarmenians surrendered themselves and their country to Rome: but there was a second cause, which greatly embittered the enmity, namely, that the king of the Romans had sent ambassadors to the barbarous tribes, who live in the interior of the Persian dominions, and whom they call Turchios: nor were there wanting minor causes of quarrel as well. As regards, however, the Turks, Justin had sent them an embassy in the seventh year of his reign, at the head of which was a prince named Zemarchus: and never before had a Roman embassy been sent to these numerous and powerful tribes.

When, then, after journeying for a year, the ambassadors arrived in their dominions, he tells us, that one of the kings of these tribes (for they have eight other chiefs who dwell farther inland) on learning that an embassy had been sent unto them by the Romans, forthwith was alarmed and terrified, and began to lament and weep bitterly. And especially when he gave them audience, and saw them standing before him, he gave way for a long time to his grief, nor did any one venture to speak to him. Some then of those in the ambassadors' suite went on to say, that when we saw him weeping thus bitterly, and that no one of his nobles ventured to speak unto him, we fell upon our faces before him, and told the interpreters to say, "We would know of thee, $O$ king, why, upon seeing us, who have been sent unto thee by thy brother, the king of the Romans, thou weepest thus?' And he, on hearing our 
question, wept yet more bitterly for a long time, and did not speak a single word in answer for the space of two hours. And then his sobbings being somewhat stilled, he said unto us, ' That you may know the cause of my present lamentation and tears, lo! I tell you, that for ages and from generations we have received this tradition, that whenever we should see ambassadors from the Romans enter these lands, we were to know for certain that the whole world was passing away, and being dissolved, and that all its kingdoms were coming to an end, and that forthwith in those times all mankind would destroy one another. And when therefore I saw you, and remembered these things, I lamented and wept.' After this, a long conference followed, and they spread out a splendid present of gold and silver and pearls, and magnificent state-dresses, and offered it unto him: and on seeing it, he was astonished, and accepted it; and picking out those articles which were most magnificent and beautiful, he said, "These are indeed the gifts of a great king.' Now by chance it so happened that there were present at that time at his court ambassadors of the Persians, and the king asked the Roman legates, 'Tell me, is it true what the Persians say, that the king of the Romans is their slave, and pays yearly tribute as a slave?' And when Zemarchus heard this, he replied, 'They speak falsely: for many Roman kings have invaded their lands, and devastated them, and taken their people captive: and when Trajan, 
a Roman king, invaded them, he so overthrew and vanquished them, that to this very day they tremble and shake before the statue of himself which he set up in their land; nor will any one of them venture, even to this day, to pass before it on horseback. But let them be summoned, and we will convict them in person of falsehood, nor will they be able to deny it.' Accordingly the king gave the command, and on their arrival, he said to them, 'Did ye not tell me that the king of the Romans is your slave, and lo! as these men inform me, to this very day ye do homage to, and tremble at, the image merely of a king of the Romans, which he set up in your land: and how, then, can they be your slaves, when ye tremble at the image of their king, and do it homage? Is this true?' They say to him, 'Yes, my lord, it is true, that there is a statue of him in our land.' And upon their acknowledging this, he said, "Why then did ye speak to me falsely, and deceive me?' And he swore, that, 'Were it not that I should then be as bad as you, I would take off your heads.' And he dismissed them in anger. Upon their return to their king, they informed him, that Roman ambassadors har visited the Turks while they were there, and had questioned them respecting the image of Trajan ; 'And as we,' said they, 'could not deny what they affirmed, he was angry with us, and sent us away in wrath.' And the Persian, on hearing this, was greatly moved and enraged, and commanded that 'Trajan's statue should be over- 
turned; and he was embittered in his enmity by this occurrence, for he imagined that the Romans were stirring up these tribes against him, especially as the king of the Turks had greatly honoured their ambassadors. Such, then, were the facts which occurred, according to the relation of the ambassadors, of which we have given a brief abstract. For on their return, after an absence of two years, they detailed much besides that was extraordinary and wonderful of the great populousness of these tribes, and the astonishing character of the regions they inhabit, and of their military institutions, and the uprightness of their morals.

VI. 24. While the Romans were waging war in the east with the Persians, in the west they were suffering almost greater miseries from the inroads of an abominable people, who, from their long hair, are called Avars. Their first appearance in the Roman territories was in the days of king Justinian, who received their ambassadors with great honour, and made them rich presents of gold and silver and dresses and girdles and saddles ornamented with gold; and sent also similar presents by their hands to their chiefs. And not only were they astonished at his bountifulness, but also quickly sent other ambassadors, whom he treated with equal munificence. And often on various pretexts they sent embassies, and he gave presents to them all, and sent them away loaded with gifts, imagining that by their means he should subdue all his enemies. And 
this continued until the murmuring against him grew general on the part both of the senate and the people; for they said, "He is stripping the whole kingdom, and giving it to barbarians.' And when Justinian departed from this world, and Justin, his sister's son, reigned in his stead, a troop of them had just come, to be loaded as usual with presents, and go their way. And after a few days they had an audience with Justin, and said to him, 'Give us as he used to give us who is dead ; and send us away to our king.' But Justin, having been one of those who were vexed and grumbled at the amount which these barbarians received, and carried out of the kingdom, answered them, "Never again shall ye be loaded at the expense of this kingdom, and go your way without doing us any service: for from me ye shall receive nothing.' And when the Avars began to threaten, he grew angry, and said, 'Do you dead dogs dare to threaten the Roman realm? Learn that I will shave off those locks of yours, and then cut off your heads.' And at his command they were seized and hurried on board some boats, and turned out of the city, and taken across the strait, and imprisoned in Chalcedon. And as their number was fully three hundred men, a force was posted there to guard them, together with some of the royal bodyguard. And at the end of six months he loosed them and sent them away, with threats, that should he ever set eyes upon any of them again, either at the capital or in any part of his 
dominions, their lives should answer for it. And thus they were terrified at him, and kept quiet, and did not shew themselves for a long time: but finally, they sent ambassadors to him to ask for friendship and make submission, and to say, that whatever he commanded them, they would do. And accordingly all his days they continued to be his friends. And as they were a powerful people, and rapidly grew in wealth and importance by the conquest and plunder of many of the northern tribes, they finally carried their arms so far as to fall upon another powerful people, called the Gepidæ, who dwelt upon the banks of the great river, the Danube; and them they conquered, and took possession. of their territories, and dwelt there, and spread themselves in the rich lands which they had occupied far and wide.

Still professing to be friends, they sent ambassadors to Justin, and cunningly asked him, in the name of their king, to send artificers and masons to build him a palace and a bath. And on their arrival there, they built him a palace and a bath; and as soon as both buildings were completed, they requested to be sent away to their homes: but now at length he shewed his treachery, and revealed the guile that was in his heart, and seized them, and drew his sword, saying, 'Unless you build a bridge by your art over the Danube, that we may pass over whenever we wish, there shall not one of you live, for I will immediately cut off your heads.' And when he pressed them, they said to him, "Who could possibly build a 
bridge over a river as wide as a sea? And even if we could do so, it would be injurious to the Roman state, and the king would put us to death. Whether therefore we die, or whether we live, we cannot do what you ask.' But upon this answer, he had two of them immediately beheaded: and the rest, terrified at the sight of their execution, promised that if he would give orders for as many large timber-trees as possible to be brought, they would make a bridge to save their lives. And upon this, a numerous body of men were sent out to cut down the tallest and largest trees: and urged on by the fear of being slain by the sword, they planned and executed a very strong bridge.

And when king Justin had reigned thirteen years, he departed from this world, and the victorious Tiberius, who had for four years been associated with him in the government as Cresar, succeeded him as sole emperor. And as this bridge was the cause of no little annoyance both to himself and the whole state, he endeavoured in the third year after the death of Justin, by all the means in his power, to cut it away, and at the time was-not able: for they occupied it, and fixed their habitations there, and further demanded of him the surrender of the city of Sirmium, on this bank of the river, for them to settle in ; and threatened, that in case of refusal, they would commence a war with him, and devastate the Roman territories. But he would not submit to abandon to them so important a city : 
and thereupon they began to assemble, and watch for an opportunity of stirring up a war. And they also made another bridge, as was said, a thing unheard of before, but which they contrived to erect, as being bent upon mischief.

VI. 25. That same year, being the third after the death of king Justin, was famous also for the invasion of an accursed people, called Slavonians, who overran the whole of Greece, and the country of the Thessalonians, and all Thrace, and captured the cities, and took numerous forts, and devastated and burnt, and reduced the people to slavery, and made themselves masters of the whole country, and settled in it by main force, and dwelt in it as though it had been their own without fear. And four years have now elapsed, and still, because the king is engaged in the war with the Persians, and has sent all his forces to the East, they live at their ease in the land, and $\mathrm{dwell}$ in it, and spread themselves far and wide as far as God permits them, and ravage and burn and take captive. And to such an extent do they carry their ravages, that they have even ridden up to the outer wall of the city, and driven away all the king's herds of horses, many thousands in number, and whatever else they could find. And even to this day, being the year 895 (A.D. 584), they still encamp and dwell there, and live in peace in the Roman territories, free from anxiety and fear, and lead captive and slay and burn: and they have grown rich in gold and silver, and herds of horses, and arms, and have learnt to 
fight better than the Romans, though at first they were but rude savages, who did not venture to shew themselves outside the woods and the coverts of the trees; and as for arms, they did not even know what they were, with the exception of two or three javelins or darts.

But to return to the war between the Romans VI. 26 . and Persians in the East. After hostilities had been carried on for some time, proposals of peace were made, and a conference held, at which the chief speakers, besides others, were the bishops of Nisibis and Resaina; and also Zacharias the Sophist, of the town of Arx Romanorum. There was, however, a certain Marzban of the Persians, who, being blinded and carried away by pride, and confident in his troops, and vain and boastful of his courage, advised the king not to give way to the Romans, nor make peace with them; 'For I,' said he, 'will immediately enter their territories, and exterminate them all, and conquer all their dominions, and will winter at Antioch.' And the king, being elated by these promises, and equally full of pride, broke off the conferences. The Marzban, therefore, whose name was Tam Khosrun,- the same who had so ignominiously put the Romans to the rout on a previous occasion,-collected his troops, and marched upon Tela Mauzalat, though there were many generals high in command, and chief officers, assembled there. And on his arrival, he surrounded the city; but the Roman commanders went out to meet him, and especially a bold and 
courageous captain, named Constantine. Now it so happened, that the day before he had laid hands upon a scout, and examined him closely as to Tam Khosrun's dress, and the part of the army in which he would probably be found. And when he had learnt every particular, he posted himself on one of the wings; and having caught sight of the Marzban in the centre of the Persian army, he charged so vigorously at him, that he penetrated into the enemy's ranks, and making straight for Tam Khosrun, smote him with his lance, and unseated him, and threw him from his horse: and turning his lance, he smote him again, and pierced him through. But he was himself now surrounded by the Persians, and slain : and so Constantine fell, who was not only a brave man, but a Christian also, and a believer. But when the Persians saw that Tam Khosrun, on whom they relied more than on the king himself, was slain, in spite of his boasts that he would forthwith take the city by storm, and lodge there; and, further, became aware that they were hemmed in on all sides by their enemies, they turned their backs, and were hotly pursued by the Romans and Arabs, who slew and unhorsed many of them, to the number, as was said, of several thousands: but as we do not know the certainty, nor how to distinguish the truth from the false rumours which fly abroad, we have not recorded the exact numbers told us. It is certain, however, that many of them fell, and three other princes were said to have been slain, and all 
their pride was brought to shame. After this defeat, they first halted at the river Bethvashi, and encamped there three months, waiting for an opportunity of renewing the contest : but finding themselves unable to stand up against the Romans, they retreated into their own land in disgrace, without having accomplished their purposes. The date of this battle ${ }^{\mathrm{z}}$ was June, 892 ; (A. D. 581.)

The next chapter repeats almost word for word what has been previously recorded respecting Maurice; but as a few new particulars are added, it may be worth while giving it entire. He tells us, then, that as the Roman generals, VI. 27. after the death of the commander-in-chief, Justinian ${ }^{\text {a }}$ the patrician, the son of Germanus, would not act in concert, the merciful king Tiberius sent Maurice to take the supreme command. For as Maurice, like himself, had been a notary, and his personal friend in earlier days, now that he was king, he promoted him, and gave him first of all the office of Comes excubitorum, or count of the bodyguard: and next sent him as commander-in-chief over all the generals and high officers of Rome in the East, with power to arrange all military matters, and to enlist and dismiss from the service, and act entirely at his own discretion. On starting for his post,

z A short account of it is given by Theoph. Sim. l. iii. c. I 8 .

a The MS. reads Constantine, but there can be no doubt that Justinian is intended. 
armed with such high powers, a considerable number of men followed him, many of whom belonged to the excubitores, while others were members of the palace-guard. And on arriving at Cappadocia, to which country he belonged, being a native of Arabissus, he selected there a large number of young men, and enlisted them under his banner as Romans: he obtained also many recruits from the province of Henzit ", in Armenia, upon his arrival there from Syria. And first he pitched his camp near the city of Citharizon, and the whole Persian land was terrified at the first rumours of him: and the Marzban, who kept the Persian Armenia, being alarmed at what was said of him, and wishing to find some excuse for getting away from his front, sent to the officers in garrison, in Theodosiopolis, the following artful message: 'How long are we to sit still and watch one another? At the expiration of thirty days, let us prepare for battle, and fight, and know who is the conqueror, and who the conquered.' And when they had received this message, the officers sent word to the count Maurice: and he gave orders that they should send in answer, 'We will be ready.' The Romans then relied upon this message, but the Marzban and his troops got away in the night, and crossed over into the Roman dominions, opposite Maipherkat, and began to pillage and burn and slay and take captive, throughout the whole district of Sophene and Amid. And b Called by Cluverius, Anzitene. 
they penetrated as far as Amid, and surrounded it, and besieged it for three days. But when they saw that they could not take the city by storm, they demanded that gold should be given them as ransom for the city, and that they might not burn the suburbs. But the people of Amid did not believe them, but considered that whether they received the money or not, they would most certainly burn them: and thereupon they were angry, and burnt all the churches, and the monasteries, great and small, and every thing outside the walls, and overran the country wherever they could; and for fifteen days continued to pillage and lead the inhabitants captive, and then returned to their land with haste, amidst the general panic of the Romans. The count Maurice meanwhile, when he heard of their inroad, was indignant, and put himself at the head of his forces, and entered Syria in pursuit of them, but could not overtake them. And thence the Roman troops, in heat and anger, entered the province of Arzun, and ravaged and burnt and wasted and led captive throughout every district there, and carried the spoil into the Roman territories, as we have mentioned before. And at the king's command the captives were sent to the island of Cyprus, and divided among the cities and villages: and there they dwell unto this day.

At the time when the main body of the Roman VI. 28. troops, under the command of two generals, 
named John and Curis ', was engaged in the endeavour to protect the Greater Armenia from the Persians, and a large Persian force lay in front of them, no less than fifty thousand men withdrew themselves, and stood aloof, being angry and full of complaint, and saying, 'Unless we receive our pay in full, and the divisions to which we are each one attached are made known to us, so as for us to be assured of our posts, not one of us will go out to war, nor will we fight with anybody.' And when news of this was carried to the king Tiberius, immediately without delay he sent thither a curator of the royal palace of Hormisdas, named Domtzolus $^{\mathrm{d}}$, and gave him a large sum of gold to divide among them, and told him to appease and satisfy them: and thereupon they made themselves ready for war. Just then it happened that the Persian Marzbans sent a message to the Roman generals, saying, "Why do we thus sit opposite one another, and watch one another like women? Let us come forth into the plain, and fight with one another.' Upon the receipt of this message, Curis, the Roman general, being a prudent man, and trained under Narses, with whom he had made many campaigns in the Roman territories, sent in reply, "We are not able to fight now,

c This is probably the Koúps spoken of by Theophylact.

d I have no doubt that Domnizolus is meant, who is mentioned in the Chron. Alex. p. 870 , as Curator of the Palace of Hormisdas about this time. 
because our whole force is not here at present; but if you will come to us, we will do our best to meet you, according as our God shall grant us the power.' And when the Magian people had received this answer, they set out with great confidence, without being on their guard, or feeling fear of the Romans. And that same day Curis quietly prepared only his own division, which consisted of about twenty thousand men, and at night, just before daybreak, he set out, when they in their camp were resting and sleeping without care, and fell upon them, 'like fire that is left in the wood, and as the flame which burneth the mountains e'? and struck them with terror and panic, and put them to the sword, or made them prisoners, except a few who escaped. Among the prisoners were a Marzban, and his son. He further spoiled their camp, and returned in great triumph, bringing with him their arms and horses.

After the death of Khosrun, his son and suc- VI. 29. cessor, Hormuzd, in accordance with the old custom of the Persian kings, of slaying all the brothers of the reigning monarch, put some of his brethren to death, and blinded the eyes of the rest. There was one, however, whom, as they said, his father had wished to reign in his stead, but the senate rejected him, and refused to accept his nomination: and, as was affirmed, king Khosrun himself supplied him with money

e Psalm lxxxiii. 14, according to the Peschito version. 
for his journey, and sent him away during his lifetime, saying to him, ' Go, my son, while I am still alive, lest you die.' And on his flight, various rumours concerning him were spread abroad, and he was supposed and reported by his countrymen to be now in one place and now in another: and this gave the opportunity to a crafty impostor among the Persians, whose youth made the personification probable, to allege and bring forward proofs, sufficient to induce people to believe that he was the son of Khosrun who had fled. He came therefore to the Roman generals in Persarmenia, and said, that he wished to make an agreement with them: 'for if the king of the Romans will acknowledge me,' said he, ' and assign me a force, I will subdue all the armies and dominions of the Persians, and will bring my brother Hormuzd, who has usurped my kingdom, and deliver him up bound to your king.' And when the generals of the Romans had fully examined into what he affirmed, and he had brought many to testify to his being the son of Khosrun, who had fled from his brother, being persuaded of its truth, they wrote an account of him to king Tiberius, detailing the investigation which they had made, and that they had found men who knew him, and bore witness to his really being the son of Khosrun, and further mentioning his destitute condition. And when the victorious king had received their report, and believed it, on the evidence reported to him by the generals, he immediately sent ambassadors, 
with large sums of gold and silver, and many dresses of honour, and horses, and numerous mules, to do him all respect, and convey him: and he gave orders that he was to be brought to the capital, and be escorted through all the Roman dominions, by the judges or sheriffs of the several districts. And this was done, and with great pomp and magnificent honours he traversed the provinces like a king; and Tiberius further sent, as he drew near, other especial marks of respect. When he arrived however at Chalcedon, and was ready to cross over to the capital, he was commanded to wait there, as the king purposed himself closely to examine his claims. For at that time a Spatharius of the king of Persia, who had come down to make peace with him, was at his court, and he knew the son of Khosrun, as also did the ambassadors whom he had brought with him: and the king, therefore, commanded them to cross over, and examine him, that he might see whether they also knew him, and could prove whether he was false or not, that so he might be sure of not being cajoled. But on crossing over and seeing him, they did not recognise him : and the Spatharius, who was himself a Persian, interrogated him at great length, and he could not prove that his claim was true. Now he was sitting upon a lofty throne, as a king, and the Spatharius went up to him, and seized him by the hair, and lifted him up, and threw him on the ground, saying, 'Do you, an impostor, who are guilty of death, 
sit upon a lofty throne, while the princes of the realm stand before you?' And he further smote him on the head: and thus he brought his falsehood to light; nor could he make any defence, or prove the truth of his claim. The king, therefore, gave orders that he should have a place appointed for him to remain in, but did not punish him as his falsehood deserved; he even assigned him a sum for his maintenance, and that of those who were with him, but he would not admit him into his presence. It is said that the expenses incurred in his behalf amounted to more than three talents. Finally, he became a Christian.

VI. 3 . From the east our historian now returns to the west, and details some particulars of the capture of Sirmium, which he describes as the inevitable consequence of the Avars having now obtained two bridges over the Danube. For gathering in great numbers, and occupying the country round, with threats of war and devastation against the Roman territories, they sent to king Tiberius, saying, 'If you would have us for friends, give us Sirmium for us to inhabit with your consent : for if not, we will take it without your consent, and be your enemies.' But the king put them off with words and various promises, as he was altogether unwilling to give the city up to them; and meanwhile he sent secretly an embassy to the Lombards, and other tribes, in the hope of hiring them, and bringing them upon the Avars in the rear. And when they pressed 
their request upon him, he determined, in order not to let them know his plans, to send unto them Narses, the great Spatharius of the kingdom, to confer with them, and waste time. He supplied him, therefore, liberally with gold, besides what Narses took of his own, and gave him secret orders not to travel rapidly on his journey thither; and should the Lombards come, he was to put himself at their head, and fall upon them, and, if possible, utterly destroy them : while to them he sent this message, 'Lo, we have appointed the illustrious Narses, our Spatharius, to come and confer with you, and conclude with you a peace.'

The illustrious Narses accordingly started from VI. 31 . the capital with great pomp, taking with him a considerable army, and a large sum in gold, and dresses of various materials. To carry them, he loaded several ships with articles of every kind, and set out upon his voyage over the dangerous sea of Pontus; but one of the vessels, on which was embarked most of the gold and his valuables, with one of his chief officers, and a number of eunuchs placed on board to keep watch over her freight, foundered the very first day of her voyage; and on learning this, which was not till after he had landed at the mouth of the Danube, he was so greatly vexed, that he fell into a serious illness, and after suffering for a considerable time in bitter mortification, his end overtook him, and he died painfully, and all his plans came to nothing, without his accomplish- 
ing any part of them whatsoever. And much trouble subsequently was occasioned in the endeavour to recover his property.

VI. 32. In consequence of Narses' death, Sirmium had to be yielded up to the barbarians. For as the Lombards, on whom Tiberius depended for making a diversion in its favour, did not appear, he was compelled to send to the Avars another ambassador in the person of the prefect of the prætorian guards, named Callistrus. And on his arrival he made over to them the city, considering that it was a more prudent course than for it to be captured by war and violence; for it had already endured for two years the extremity of famine, and after eating their cattle and beasts of burden, they had finally been compelled to feed upon cats and other such things, and had suffered privations no less bitter than those which the Scripture describes as having happened at"Samaria. People speak also of the compassion shown by the barbarians to the inhabitants, on seeing the pitiable condition to which they were reduced by famine, and which well deserves the admiration of Christians, whose conduct too frequently it condemns; because they do not show kindness to their fellow-servants, nor pity those of their own flesh. For when, upon entering the city, they saw the mortal misery of the people, they had compassion upon them, and gave them bread to eat and wine to drink. But when, after the emptiness of hunger, endured for a period so protracted as 
two years, they seized upon the food and ate it greedily, many immediately fell down suddenly dead. Finally, the survivors had to depart from the city, and the barbarians took possession of it, and dwelt there.

About a year, however, after the barbarians VI. 33 . had occupied this Christian city, a fire broke out, -from what cause God alone knows,-and suddenly it was brought to ruin, and became the prey of the flames; and as the barbarians neither knew how to prevent its progress, nor extinguish it, they all fled without being able to save any of their property, and abandoned it, and it was burnt, and utterly ruined. And many other occurrences in its history would be interesting to relate, but because of the length of our narrative, we have been compelled to omit them.

For what we have attempted has been nothing VI. 34 . more than briefly to record some special incidents in the wars which have been successively carried on, and into the exact truth of which we have carefully examined; and thus we have described the attack of the illustrious patrician Marcian upon the town of Nisibis, and the events which followed. And next, we have shown how Khosrun, at the head of his armies, crossed over into the Roman territories, and took Dara and Apamæa by siege, and various other towns. Next came the arrival of the illustrious Maurice in the east with great pomp; and we described the fear which fell upon the whole Magian people, 
and how, in the hope of deceiving him, they crossed over by stealth into the Roman territories in the neighbourhood of Maipherkat, and rapidly carried fire and sword for fifteen days throughout every part of Sophene, and as far as Amid; and when they saw that they could not take the city by storm, in barbarous fury they set fire to and burnt all its suburbs, and the churches, and monasteries, and every thing else situated there. And carrying with them their spoil, they hastily returned to their own land. We next related how count Maurice, on learning these things, was greatly enraged, and pursued them, but could not overtake them, and proceeded with haste into the land of Arzun, and burnt and destroyed and took captive and carried away such of the inhabitants as he did not kill, and brought them into the Roman territories, and that finally they were sent to the island of Cyprus. He also stormed several fortresses there, one of which, named Pum, he occupied, and placed in it a Roman garrison : but the fort opposite, the name of which is Klimar, is still held by the Persians, who paid Maurice a sum for its ransom; and the two garrisons dwell in face of one another, but they have come to an agreement, and mutually give and take without fear.

VI. 35. There was also another fort which count Maurice took measures for building upon a lofty and strong mountain, named Shemkoroth, whence the fort also took its name; and he put a garri- 
son into it, and supplies of provisions, and took measures for its safety in every thing. This fort then of Shemkoroth is situated in the Roman dominions; and the building of it was intrusted to an architect to whom Maurice had sent orders for its erection while he was himself in Persia.

There was also another fort, named Oeba, on VI. $3^{6}$. the river Chalat in Persia, the history of which is as follows: On the bank of this river, on the borders opposite Maipherkat, is a precipitous hill, which for many years the perverse race of the Magians had been anxious to seize upon as a site for a fortress ; but as there is a compact between the Romans and the Persians, extending to a certain number of miles from the border, neither the one nor the other had the right to build there; and therefore the Romans resisted them, and would not suffer them to erect any works upon it. For the building of the fort was often begun, and as often prevented. But once upon a time, as we have related before, the Persians found an opportunity, and built a fort there, and garrisoned it. But after some years had elapsed, the Roman armies attacked it, and under the command of a general named Aulus, they invested it on all sides, and commenced a blockade. And in process of time the garrison was reduced to such extremities of hunger and thirst, that their lives were all but exhausted; and on seeing that they could hold out no longer, they requested that their lives might be assured them, and that they should neither be seized nor made captives, nor 
taken into the Roman dominions; and upon these terms they said that they were willing to yield up the fort, and withdraw. And the generals accepted the terms, and gave them the required promise, upon which they opened the gates, and came down; but upon meeting with water, and drinking of it, so many of them suddenly fell down dead, that but few finally returned to their country. Upon the surrender of the fortress, the general and his army ascended to it, and rased it to the ground, leaving not one stone upon another, but utterly destroying it, and casting the materials down from the mountain top. Before its capture, other generals and a large force had been collected, and they were posted some here and some there, in various places, and took the watch in turn. The capture of Ocba took place in the year 894 (A.D. 583).

Of the remaining thirteen chapters of the book but a fragment exists, and it contains little more than is told us in the headings, all of which are still extant. From them we learn that an embassy was sent to Maurice, now emperor of the Romans, to sue for peace; and that he in return sent an ambassador to the Persian court, which was followed by a second embassy to Constantinople. The fortieth chapter contained a statement of the mutual losses sustained by the two states of Rome and Persia during the ruinous wars occasioned by the weak policy of Justin: and this was succeeded by an account of the rise 
and subsequent decline of the kingdom of the Roman Arabs, occasioned possibly to some extent by the defection of several of their leading princes to the Persians. Next, there was the capture of some famous Marzbans, who were sent as prisoners of war to the capital. The fortyfourth chapter detailed the history of another war, waged probably with the Persians in the third year (of Maurice), and of the victory which God gave the Romans. The next three treated of the 'base, barbarian, long-haired people,' called Avars, who invaded Thrace, captured many cities, and numerous forts, and carried terror and alarm to the very walls of Constantinople, at a time, when, says our historian, we ourselves were there. The forty-eighth chapter gave an account of the manner in which the land was taken possession of, and wasted by the Slavonians: and the forty-ninth, and last, recorded the destruction of the city of Anchialus, and described the warm baths there.

It seems plain that these chapters were penued one by one as the events themselves occurred, and probably they were brought to an abrupt conclusion by the death of the good old man who wrote them. Little did he foresee that the prudent and victorious Maurice, together with his sons, and among them that Theodosius, whose birth in the purple, after so long a series of childless sovereigns, he had so rejoiced in, would perish by the hand of the executioner: and that 
the daughter of Tiberius, the one emperor whose name no stain or spot defiles, would be dragged, with her children, amidst the apathy of the populace, to the same cruel fate. Scarcely too could he have foreseen, that before many years had elapsed the Avars would lay siege to the capital itself; while across the strait, the hosts of another Khosrun encamped within the walls of Chalcedon, and, fresh from the conquests of Syria and Asia, would insult the city which still called itself by the proud name of Eastern Rome. And behind there was a yet darker hour: for the two empires, which had so long struggled for the mastery of the world, were about to fall before a kingdom and a creed which were but just struggling into existence.

With the victorious Khosrun the throne of Cyrus perished, and Arab Chalifs reigned upon the Tigris and Euphrates: while Heraclius had to yield to the partisans of the same conquering faith the provinces which his heroic vigour had wrested from the Persian arms. But these dark scenes of history our author did not live to behold: he had suffered under the cruelties of the weakest of the effeminate despots who held sway at Constantinople: he had had the happiness of living for four years under the government of the best: and Maurice, though with colder affections, endeavoured to tread in his steps. His last days were calm and tranquil: his last hopes pictured perhaps a new era of prosperity for his country, 
and of peace for the church: but his own history shews that the times were ripe for punishment. The salt had lost its savour: and nothing remained but for it to be cast unto the dunghill, and trodden under foot of men.

F I N IS. 



\section{N D E X.}

A.

Abraham, monastery of, 17 , note.

Acacius Archelaus, successor of Marcian, 368 .

Acephali, subdivision of Monophysites, 58 .

Achudemes, first Catholicus of Monophysites in Persia, 418 , 420 , note.

Acœmetæ, monks so called, 23, note.

Adormahun, captures Apamea, 385 . invades Mesopotamia, 406. and Osrhoene, 4I 4 .

Adultery, term applied to bishops who invade sees of others, 269. or are translated, $i b$. note.

Advent of Christ, daily expected, 366 .

Etherius, the accursed, 140.

Alexandria, chief seat of Monophysites, 69. its leading men and shipowners summoned to the capital, $i b$. two Monophysite patriarchs elected there, 70, 264, 266. clergy arrested and sent to Constantinople, 70, 295. set free by intercession of Mondir, 304. succession of patriarchs, 77. manner of investiture of patriarch, 275 , note. three rival patriarchs there, 308 . spite of clergy against Longinus, 316 . embassy to kings of Nobadæ and Alodæi, 316, 317. their letter, 318.

Alodæi, their conversion, 314,316 . their king requests that Longinus may be sent to him, 319 . his letter to the king of the Nubians, 320.

Ambassadors to Persia, 128. their exertions for Paul, 293. account of their proceedings, $403,42 \mathrm{r}$. to Turks, 424 .

Amid, its suburbs burnt by Persians, 437,446 .

Anastasius, the quæstor, 30 . possessed by an evil spirit, 139 .

Anastasius, patriarch of $\Lambda$ ntioch, 79 .

Anastasiopolis, see Dara. 
Anatolius, governor of Edessa, a heathen, 210 . his artifice, $21 \mathrm{I}$. inserts image of Apollo in picture of Christ, 214. his execution, 223.

Andrew, the queen's pursebearer, 101 .

Angel, an, dictates Justin's speech to Tiberius, 172.

Anthimus, patriarch of Constantinople, 82 .

Antioch, succession of patriarchs, 78 .

Antipatra, banished to a nunnery, 109 .

Antonina, wife of Belisarius, 66.

A pamæa, its capture, 385 .

Arabissus, rebuilt by Maurice, $36 \mathrm{r}$. destroyed by an earthquake, 363.

Arabs of Hirah and Ghassan, 244, diss.

Armenia, revolt of, II $8 \mathrm{seqq}$. returns to its allegiance, 402 .

Arians, their persecution, 354 .

Arzun, invaded by Maurice, $41 \mathrm{I}, 437,446$. Christian captives taken there sent to Cyprus, 4I 2.

Askalon, bishop of, tortured by Photius, 67 .

Assyrians, Persians so called, 385 , note.

Athanasius, grandson of Theodora, founds a heresy, $5^{\mathrm{I}}$. his legacy to Conon, 59 .

Augustaticum, what, 185 , note.

Avars pillage Thrace, 142 . account of them, 428 . build a bridge over the Danube, 430. demand Sirmium, 43 I, 442 . it is delivered to them, 444. their kindness to the besieged, ibid.

B.

Baalbec, persecution of Christians there, 209.

Believers, name of Monophysites, 6, note, et passim.

Bethvashi, river, 435 .

Bostra, besieged by sons of Mondir, $24 \mathrm{I}$.

Bread, ä

C.

Cæsar, title of successor designate to Byzantine empire, 72.

Callistrus sent to surrender Sirmium to Avars, 444.

Campagi, what, 56, note.

Captives, taken by Khosrun, their message to Tiberius, 416 .

Cartamin, monastery of, 291, note.

Catenæ, their use forbidden by Scripture, 63 . 
Catholicus, chief ecclesiastical dignitary of Armenia, 118. C. of Dovin takes refuge at Constantinople, 125. communicates by error with synodites, I 26. his death, ibid. C. of Nestorians in Persia, 418. of urthodox, 420.

Cellarius, what, I I 2 , note.

Chalat, river in Persia, 447.

Chalcoprateia, quarter in Constantinople, 196, note.

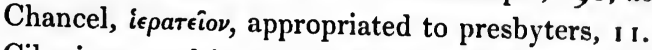

Ciborium, used in all the churches of Constantinople, 362.

Cometes, head of diaconate, i 15.

- interpreter at Dara, ${ }_{3} 8 \mathrm{r}$.

Condobaudites, 49, seqq., 65 .

Conon, heresiarch, 49, seqq.

Constantine, slays Tam Khosrun, 434 .

Constantinople, riot at, 216.

Cross, adoration of, 139 .

Curis, or Curs, his troops mutiny, $43^{8}$. defeats the Persians, 439.

Cyril of Alexandria, his reconciliation with John of Antioch, 24.

D.

Dalmatus, monastery of, 104 .

Damianus, patriarch of Alexandria, 78. rejects Tritheites, 62. founds a sect, $i b$. originally an ascetic at Mount Thabor, 290, note. endeavours to consecrate a patriarch of Antioch, 301 . his ridiculous escape, $3 \circ 3$. consents at Constantinople to a reconciliation, 304 . breaks it, 306 .

Dara, its siege, 379 . capture, 382 . account of, 407 , note.

Derira, monastery of, 230 .

Deuterius, bishop of Caria, 159 .

Diaconates, I I I, I I 3 .

Diacrinomeni, see Distinguishers.

Dios, monastery of, 17 , note.

Diptycks, their use, 79, 1०8,

Distinguishers, why so called, 187 , note, 354 .

Domitian, bishop of Melitene, prime minister of Maurice, $35^{6}$.

Domtzolus, or Domnizolus, sent to appease mutiny in army in Armenia, 438.

Donativum, what, 185 , note.

Dorotheus, Julianist pope of Alexandria, 77. 
Dovin, capital of Armenia, I 18.

Dream of Monk, 12 .

E.

Elephants, their Christian behaviour, $16_{2}$.

Elisha, bishop, refuses to be reconsecrated, 17. imprisoned in patriarch's palace, 23 .

Embassy, see Ambassadors.

Ephesus, synod of, called Synod of the East, 79.

Ephraim of Amid, patriarch of Antioch, 79 .

Eubulus, hospice of, 90, note.

Eudæmon, the consul, 107.

Eugenius, associate of Conon in consecrating Tritheite bishops, 53. his death, 59 .

Eulogius, patriarch of Alexandria, 77. accused of sacrificing to Jupiter, 2 I 3.

Euphrasius, patriarch of Antioch, 79.

Eustochius, bishop of Jerusalem, his murder, 227.

Eutychius, patriarch of Constantinople, 82. his deposition, 2 . his miracles, and restoration, 134 . destroys his predecessor's pictures, 134, and persecutes his relatives, 145. makes a catena upon the two natures, 146,197 . defends the Athanasians, 147. persecutes the orthodox, 150, 200. writes a new antiphon, 155. wishes to alter the Trishagion, ${ }_{5} 6,198$. rumours of his miracles, 195. adopts heresy of John Grammaticus, $i b$. is tormented by a devil, 196 . his pride, 198 , and death, 233. refuses audience to Alexandrine elergy, 295.

Execution, barbarous method of at Constantinople, 2 I 8.

F.

Flavianus, patriarch of Antioch, 78.

Fravian, slave of Andrew, 151 . persecutes orthodox, $i b$.

G.

Gaianus, patriarch of Alexandria, his election and tenets, 275, note.

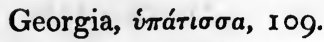

Goths, in Roman service, 188,207 . wish for a church in which their wives may worship as Arians, 189.

Gregory, patriarch of Antioch, 79. accused of sacrificing to Jupiter, 213 . his trial, 225. builds a hippodrome, 226. 
H.

Harith, king of the Arabs, character of, 370 .

Heathen, persecution of, 209. inquisition after, 223.

Hebdomum, what, 350 , note.

Hermits, Ægyptian, supposed to know futurity, 70. sent for to foretell future events to Justin and Sophia, $i b$.

Hirah, signifies a camp, 245. applied to capital of Ghassanide Arabs, 285 , and of Persian Arabs, 378.

Hormisdas, palace of, 103 , note.

Hormuzd, succeeds Khosrun, 423. his pride, $i b$. slays or blinds his brothers, 439 .

Hosannahs, week of, 4 , note.

Hypatia, what, I 85 . note.

I.

Ino, wife of Tiberius, 180 seqq. her hostility to the orthodox, 243.

J.

Jacob Burdoho, Baradæus, or Zanzalus, founder of sect of the Jacobites, his simplicity, 273. admits Paul to communion, 274. disapproves of Peter's election at Alexandria, 275. his visit there, 278 , and marvellous death, 291, 332.

Jacobites and Paulites, their reconciliation, 279.

John, Ascunages, founder of Tritheites, $5 \mathrm{I}$.

- the consul, ro7. ambassador to Persia, 293, 403 .

- of Ephesus, one of the four bishops, 23. rejects Tritheites, 53. his office at Constantinople, $i b$. warns Conon, 60. refuses Stephan's mediation, 91. plagued with gout and vermin, 92. sees a vision. 94. banished to an island, 99. compelled to give up a hall which he had converted into a monastery, I 57. dispute about the furniture, 158. apologizes for want of arrangement in his narrative, $16_{3}$. is imprisoned in the chancery, 192. was a fellow-courtier with Tiberius, 202. superintendant of the heathen, 229. his missionary labours, 230 seqq. refuses to communicate with Peter, patriarch of Antioch, 309. his letters to Jacob Zanzalus, $3 \mathbf{I}$.

the Faster, patriarch of Constantinople, 234. his ascetic habits, 235. refuses to persecute, 353,360 .

John Grammaticus, see John Philoponus.

John Nesteustes, see John the Faster. 
John, the patrician, patriarch of Antioch, 77, 295.

- Philoponus, his works, 51,57 .

Scholasticus, of Sirmin, or Sirimis, patriarch of Constantinople, 82. a lawyer, 2. persecutes bishop Elisha, 17. whips Stephan, 18. his debates with the four bishops, 23. offers them bishoprics, 45. his pictures obliterated after his death, 72. rebuffed by Tiberius, $i b .187$. testimony to Monophysites, ib. 187. illness, 74. punishment and death, $\mathrm{I}_{3} 2$.

Julian, the prefect, his method of punishing rioters, 221 .

missionary to Nubia, $25 \mathrm{I}, 3 \mathrm{I} 5$. sufferings from the heat, 25.5 return and death, 256 .

Juliana, banished to a nunnery, rog.

Julianists, who, 78 , note.

Julius Cæsar, church history begins with, 3 .

Justin II, emperor, forbids re-consecration of bishops, 2I. draws up articles of faith, 28. visits the warm baths, 44. offers vacant sees to Monopbysites, 45. consults Egyptian fortunetellers, $7 \mathrm{r}$. his chastisement, 164. amusements devised to beguile his madness, 169. strikes the patriarch, $i b$. speech to Tiberius, 172. painful death, 177 . figure of Venus on his coins, 192. his buildings, 204. statues of himself and Sophia, 205. pharos, $i b$. tries to murder Mondir, 372 . length of reign and date of death, 349 .

Justinian, emperor, bears expenses of John's mission and of new churches in Asia, 231. rebuffs bishop of Tralles, 233. sends a counter mission to Nubia, $25 \mathrm{I}$. date of death, 349 .

son of Germanus, the patrician, declines battle with Khosrun, 395. has 60,000 Lombards in his service, 407. his death followed by want of concert among the generals, 435 .

$\mathrm{K}$.

Khosrun, Nushirwan, 119. invades Armenia, 391, and Cappadocia, 392. burns Sebaste, 393. loses his baggage, 394. burns Melitene, 395. defeated on the Euphrates, 397. his law that kings of Persia shall only go in person to war with another king, 398. his eulogy, 417. readiness to make peace, 420.

pretended son of, 440. detected by Persian Spatharius, 44I. kindly treated by Tiberius, 442 .

Klimar, fort of, 446 . 
L.

Lombards, sixty thousand serve under Justinian in the east, 407 .

Tiberius endeavours to hire them to attack Avars, 442.

Longinus, chaplain to pope Theodosius, 250. missionary to Nubia, ${ }_{25} 6$. invited to consecrate pope of Alexandria, $25^{8}$. consecrates Theodore, $26_{3}$. his journey to Syria, $28_{5}$. returns to Nubia, 316. travels on to the Alodæi, 3 19. his letter to king of Nubia, 321 .

M.

Magister, title at Constantinople, $4 \circ 3$ note, 417.

Magnus, his treachery, 237. and death, 242.

Maipheracta, or Maipherkat, account of, 410, note. ford of, 436,446.

Makoritæ, endeavour to prevent Longinus reaching Alodæa, 3 19.

Marcian, the patrician, besieges Nisibis, 367 . deprived of command, 368. reason of Justin's antipathy to, 372 .

Marianum, church of believers there, 194.

Mary, Blessed Virgin, her church at Blachernæ, 1 5 . her robe, ib., note.

Marzban, meaning of, I 2 I, note.

Maurice, Cæsar, 350. emperor, 35 I . marries Tiberius' daughter, ibid. birth of a son in the purple, ibid. his nepotism, 355 . want of money, 357. stinginess, 358. rebuilds Arabissus, 361 . originally a notary, 435 . made commander-in-chief, 408,435 . enlists a large army, 409, 436. invades Arzun, 4 I I, 437, 446. his quarrel with Mondir, 413. his forts, 446.

Mennas, patriarch of Constantinople, 82.

Minas, or Mennas, S., description of his church, $26 \mathrm{I}$, note.

Monasteries at Constantinople, 6.

Mondir, the Arab, son of Harith, accused of treachery to Maurice, 236 . betrayed by Magnus, 237. carried to Constantinople, 239. dissertation upon, 244, seqq. endeavours to reconcile Paul and Jacob, 284, 294. effects a compromise, 297. first visit to Constantinople, ibid. leaves with great honour, 304. stops persecution at Antioch, 305. his victories, 305 , $370,378,4^{1} 5$. asks Justin for a subsidy, 372 . Justin plans his murder, $i b$. the letter falls into his hands, 373 . reconciliation, 376.

Monks, tried for murder before civil courts, 288 .

Monophysites, their patriarchs, 1 . creed, 7, 39, 6r. numerousness, 359 . 
N.

Narses, rejects Tritheites, 54. his monastery of Cathara, 75 .

- Grand Spatharius, his embassy to Avars, 443. his treasures shipwrecked, $i b$. dies of vexation, $i b$.

Nestorians, strict, who, 30 . discussion in Persia with Monophysites, 418.

Nice, nineteenth canon of council of, 21,25 .

Nisibis, besieged by Marcian, 367 . siege raised, ${ }_{3}^{6} 9$.

Nobadæ, or Nubians, their conversion, 250. letter of king of to Theodore, pope of Alexandria, 324.

Noman, son of Mondir, avenges his father, 240.

Nubia, its geography, $33^{8}$, diss. Christian inscriptions, 34 I, seqq.

Nuns, constancy of two sisters, 152 . refuse to permit alteration of Trishagion, 199. indignation at disorderly burial of Paul, 330.

O.

Ocba, fort of, 447 .

CEcumenical bishop, title assumed by patriarchs of Constantinople, $10, \mathrm{I} 6$.

Orthodox, name assumed by Monophysites, 6, note, et passim.

P.

Pamphylia, possessed by Monophysites, 58 .

Patriarch's palace, a prison, $17,23,36$. its internal discipline, 37 . Paul of Antioch, founder of diaconates, 114.

- the black, patriarch of Antioch, one of the four bishops, 23. his quarrel with Jacob, $8 \mathrm{r}$. imprisonment, 85. writes a history, ibid. consents to communion with Synodites, 87 . flight, 89. consent of distant bishops required to his reception to communion, 260. Asseman's account of him, ibil., note. his act of penitence, 274. received back into communion, $i b i d$. deposed by Peter, pope of Alexandria, 278. schism which followed, 28r. his moderation, 284. retires (as was supposed) into mountains of Isauria, 312 . concealed near Constantinople, 327. his death, 329 . and burial, 330 .

— the Jew, patriarch of Antioch, 79.

metropolitan of Aphrodisias, his reconsecration, 14. nicknamed ' the double-dyed,' $i b$. his lamentation, and death, 15 ,

16. recantation, $i b$.

Pearl, what, 105. 
Persians, artifice to deceive Maurice, 436 .

Peter, patriarch of Alexandria, 78 . consecrates seventy or eighty bishops, ib., 269. deposes Paul of Antioch, 278.

- of Callinicus, patriarch of Antioch, 81, 309. endeavours to appease schism, 334 .

- the consul, 107. ambassador to Persia, 293, 403.

Photius, son of Belisarius, 52, 66.

Physicians, their cowardice, 177 . and infidelity, 360 .

Pictures in churches, 9, 134 .

Pum, fort of, 446 .

R.

Rabula, monastery of, III.

Reordination of priests and bishops, $\mathrm{I}$.

Resaina, see Theodosiopolis.

Romans, defeat of by Tam Khosrun, 399. ascribed to their cruelty to Christians, $40 \mathrm{I}$.

Romanus, head of diaconate, i 5 .

Rome, respect for, 42 . archdeacon of, demands inquiry into claims of Eutychius and John, 144.

Rufinus, high-priest of Jupiter, 210. death, $21 \mathrm{I}$.

S.

St. Martin, his account of revolt of Armenia, 129 , note.

Sampson, hospital of, 83 .

Sapor, granted liberty of faith to Armenia, I 2 I.

Scete, desert of, magnificence of hermits there, $26 \mathrm{I}$, note.

Sea of weeds, what, 3 I 9 , note.

Secretum, what, 36 , note.

Sergius, first Monoph. patriarch of Antioch, $8 \mathrm{I}$. persecution of two of the name, 1 io.

Severus of Antioch, chief Monoph. authority, 51, 55. his election, 78 .

Shemkoroth, fort, 446 .

Sirmin, or Sirimis, village near Antioch, 4.

Sirmium, surrendered to Avars, 444. famine endured by the besieged, $i b$. destroyed by fire, 445 .

Slavonians occupy Greece, $43^{2}$.

Sophene ravaged by Persians, 436, 446 .

Sophia, empress, niece of Theodora, originally a Monophysite, 105. her conversion, 106. considers Justin's malady a punishment for his neglect of her, $17 \mathrm{I}$. refuses to admit 'Tiberius' 
wife into the palace, 178 . intends to marry Tiberius, 179. forbids ladies of Constantinople to pay respects to the Cæsar's wife, 180 . plots against Tiberius, 183 . secretes large sums of gold, I84. her ill temper, 185 . quarrels with Tiberius about finishing Justin's pharos, 206.

Spatharius, Persian, detects the pretended son of Khosrun, 44 I. grand, see Narses.

Stephan, bishop of Cyprus, his beating, 18. outcry at reconsecration, 22. one of the four bishops, 23. intercedes for Paul, 87. sent to John of Ephesus, 90.

Stylites, what, $3 \mathrm{~J} 4$, note.

Syncellus, what, i I 0 , note.

Synodites, name of followers of council of Chalcedon, 6, note.

T.

Tam Khosrun defeats the Romans, 399. attacks Tela, 433. is slain, 434 .

Tela, or Tela Mauzalat, account of, 407 , note. besieged by Tam Khosrun, 433.

Telbesme, account of, 407 , note.

Thallus, head of diaconate, II 4 .

Theodora, empress, wife of Justinian, a Monophysite, 1 . her measures for the conversion of Nubia, $25 \mathrm{I}$.

Theodore, abbot of Rhamnis, patriarch of Alexandria, 77. consecrated by Longinus, 262 . his gentleness, 271,313 . complains of neglect, 3 34,328 . visits Cyprus, $i b$.

the patrician, ambassador to Persia, 293, 403.

bishop of Philæ, takes the oversight of Nubia, 255,

315. appoints Longinus his proxy, 259 .

secretary of Anatolius, 213. confesses human sacri-

fices of patriarch of Antioch, $i b$. dies in prison, 214, 223.

son of, burnt to death in a boat, 218 .

the silentiary, taken by Khosrun to Theodosiopolis,

391. his answer, 392, note.

Theodosiopolis, account of, 124,407 , note.

Theodosius, patriarch of Alexandria, exiled by Justinian, 2. his influence at Constantinople, ib. 250. election and deposition, 275 , note.

chief presbyter of clergy of Alexandria, his death, 296.

Theodulus, his theft of alms-money, and detection, 136 . 
Theophilus, his mission to punish the heathen, 209 .

Tiberius, cross-examines John of Sirmin about the Monophysites, 72,187 . refuses to persecute, 73 . is made Casar, 172,350 . surnamed Constantine, 175 . places his wife in the palace of Hormisdas, 179. his romantic marriage, 180, 208. lavishness, 185. accused of Arianism, I 88. orders Arians to be persecuted, 189. remits taxes, 190. a cross on his coins, 192. not to be blamed for permitting Eutychius to persecute, 20I. his gentleness, 203. buildings, 204. wars, 207. hires the Goths, $i b$. death, 243, 350. neglects rescue of Christian captives, 417 . exacts hard terms of peace from Khosrun, 404, 423.

Timus Esthartus, same as Greek Timostratus, 380.

Trajan, synonymous with persecutor, 222. dread of Persians at his statue, 427 .

Tralles, heathen temple near, converted into a monastery, 230 . claimed by bishop, 232 .

Tritheites, $5^{\circ}$, seqq.

Turks, Khosrun sends them two thousand Christian maidens, 388 . embassy to them, 424 .

V.

Vardun, or Vartan, the Mamigonean, leader of Armenian revolt, 129, note. remains at Constantinople, $4 \circ 3$.

Virgins, two thousand selected for the 'Turks, $3{ }^{3} 7$. their death, $39^{\circ}$.

W.

Week, names of days of, in Syriac, 4 , note.

\section{$\mathrm{Z}$.}

Zacharias, the sophist, 28. accompanies ambassadors to Persia, 403,433 .

Zeno, emperor, his Henoticon, 58, note.

Zeuxippus, at Constantinople, what, 205 , note. 



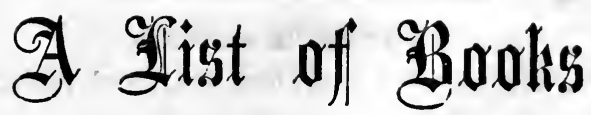

RECENTLY PUBLISHED BY

\section{JOHN · HENRY AND JAMES PARKER,}

OXFORD, AND 377, STRAND, LONDON.

\section{NEW THEOLOGICAL WORKS.}

\section{DAILY SERVICES.}

\section{DAILY SERVICES OF THE CHURCH OF ENGLAND.} A new Edition, on thick paper and in clear type, with red Rubrics, in 2 vols. crown 8vo., morocco, 1 l. 10s. Also on thin paper, in one volume crown 8vo., morocco, 16s.

Both editions of this work may be had in a variety of elegant bindings.

Having been requested by Mr. PARKER to examine his new edition of the "Daily Serrices" of the United Church of England and Ireland, and to express my opinion of it, I, having done so, most warmly commend it to all Churchmen, and especially to the Clergy, who will find in it a great help towards maintaining that godly and wholesome use of these Daily Services which the Prayer-book enjoins on "all Priests and Deacons who are not let by sickness or some other urgent cause."

S. OXON.

Cuddesdon Palace, Dec. 7, 1856.

\section{REV. C. MARRIOTT.}

LECTURES ON THE EPISTLE OF ST. PAUL TO THE ROMANS. By the late Rev. C. Marriotr, B.D., Fellow of Oriel College, Oxford; Vicar of St. Mary-the-Virgin in the city of Oxford; and sometime Principal of the Diocesan College, Chichester. Edited by his brother, the Rev. John Marriot t, M.A., Curate of Bradfield, Berks. 12mo., cloth, 6s.

\section{REV. F. MEYRICK, M.A.}

THE WISDOM OF PIETY, AND OTHER SERMONS, addressed chiefly to Undergraduates. By the Rev. Frederick Meyrick, M.A., Her Majesty's Inspector of Schools; Fellow of Trinity College; late Select Preacher before the University of Oxford, and Her Majesty's Preacher at Whiteliall. Crown 8vo., 4s.

\section{PROFESSOR MANSEL.}

THE BAMPTON LECTURES FOR 1858.-THE LIMITS OF RELIGIOUS THOUGHT EXAMiNED. By Henry Longueville MaNser, B.D., Reader in Moral and Metaphysical Philosophy at Magdalen College. Fourth Edition. 8vo., 12s.

\section{THE IORD BISHOP OF OXFORD.}

THE ORDINATION SERVICE. ADDResses on the Questions to the Candidates for Ordination. By the Right Rev, the Lord Bisiop OF OXFond. Crown 8vo.

[n the press.

\section{REV. H. NEWLAND.}

A NEW CATENA ON ST. PAUL'S EPISTLES. A Practical and Exegetical Commentary on the Epistles of St. Paul : in which are exhibited the Results of the most learned Theological Criticisms, from the Age of the Early Fathers down to the Present Time. Edited by the Rev. Henkr Newland, M.A., Vicar of St. Mary Church, Devon, and Chaplain to the Bishop of Exeter. 8vo. 


\section{OXFORD LENTEN SERMONS.}

A SERIES OF SERMONS preached in Oxford during the Season of Lent, 1859. Fcap. 8vo., 5s.

THE SERIES FOR 1857. 8vo., 14s.

THE SERIES FOR 1858. 8vo., 11 s. 6 d.

REV. T. LATHBURY, M.A.

A HISTORY OF THE BOOK OF COMMON PRAYER, AND OTHER AUTHORIZED BOOKS, from the Reformation; and an Attempt to ascertain how the Rubrics, Canons, and Customs of the Church have been understood and observed from the same time: with an Account of the State of Religion in England from 1640 to 1660 . By the Rev. Thomas Lathbury, M.A., Author of "A History of the Convocation," "The Nonjurors," \&c. Second Edition, with an Index. 8vo., 10s. 6d.

\section{REV. E. B. PUSEY, D.D.}

THE COUNCILS OF THE CHURCH, from the Council of Jerusalem, A.D. 51, to the Council of Constantinople, A.D. 381 ; chiefly as to their Constitution, but also as to their Objects and History. By the Rev. E. B. Pusey, D.D., Regius Professor of Hebrew ; Canon of Christ Church ; late Fellow of Oriel College. 8 vo., 10s. $6 \mathrm{~d}$.

THE DOCTRINE OF THE REAL PRESENCE, AS CONTAINED IN 'THE FATHERS. By the Rev. E. B. PuseY, D.D. 8vo. cloth, 12s.

"This work contains in order every passage in the Fathers bearing on the doctrine of the Real Presence down to A.D. 451, including all fragments recently discovered."

THE REAL PRESENCE THE DOCTRINE OF THE ENGLISH CHURCH. By the Rev. E. B. Pusey, D.D. 8vo., cloth, 9s.

NINE SERMONS preached before the University of Oxford, and printed chiefly A.D. 1843-1855, now collected into one volume. By the Rev. E. B. Pusey, D.D. 8vo., 9s.

\section{THE DEAN OF FERNS.}

THE LIFE AND CONTEMPORANEOUS CHURCH HISTORY OF AN'TONIO DE DOMINIS, Archbishop of Spalatro, which included the Kingdoms of Dalmatia and Croatia; afterwards Dean of Windsor, Master of the Savoy, and Rector of West Ilsley in the Church of England, in the reign of James I. By Henry Newland, D.D., Dean of Ferns. 8vo., cloth lettered, $7 \mathrm{~s}$.

\section{REV. JOHN KEBLE.}

ON EUCHARISTICAL ADORATION. By the Rev. JoHr KebLe, M.A., Vicar of Hursley. Second Edition. 8vo., 3s. $6 \mathrm{~d}$.

AN ARGUMENT for not proceeding immediately to REPEAL the LAWS which treat the NUPTIAL BOND as INDISSOLUBLE. 8vo., 1s.

Also, recently published, by the same author,

SEQUEL of the ARGUMENT against immediately REPEALING the LAWS which treat the NUPTIAL BOND as INDISSOLUBLE. By the Rev. John Keble, M.A., Vicar of Hursley. 8vo., 4s. 6 d. 


\section{EDITOR OF GLOSSARY.}

SOME ACCOUNT OF DOMESTIC ARCHITECTURE IN ENG-

LAND, from Richard II. to Henry VIII. (or the Perpendicular style.) With Numerous Illustrations of Existing Remains from Original Drawings. By the Editor of "The Glossary of Architecture." In 2 vols., 8vo., $1 l .10 \mathrm{~s}$.

$$
\text { Also, }
$$

Vol. I.-FROM WILLIAM I. TO EDWARD I. (or the Norman and Early English styles). 8vo., 2Is.

Vox. II.-FROM EDWARD I. TO RICHARD II. (the Edwardian Period, or the Decorated Style). 8vo., 21 s.

The work complete, with 400 Engravings, and a General Index, 4 vols. 8 vo., price £3 12 s.

\section{PROFESSOR WILLIS.}

FACSIMILE OF THE SKETCH-BOOK OF WILARS DE HONECORT, an Architect of the Thirteenth Century. With Commentaries and Deseriptions by MM. Lassus and QuIcherat. Translated and Edited, with many additional Articles and Notes, by the Rev. Robert Willis, M.A., F.R.S., Jacksonian Professor at Cambridge, \&c. With 64 Facsimiles, 10 Illustration Plates, and 43 Woodcuts. Royal 4to., clotl, $2 l .10$ s.

\section{RAYMOND BORDEAUX.}

SPECIMENS OF MEDIEVAL IRONWORK. Serrurerie du MoyenAge, par Ra.Ymond Bordeaux. Forty Lithographic Plates, by G. Bouet, and numerous Woodcuts. Small 4.to., cloth, 20s.

\section{JOHN HEWITT.}

ANCIENT ARMOUR AND WEAPONS IN EUROPE. With numerous Illustrations from Contemporary Monuments. By JонN Hewirt. The Second (and concluding) Volume, comprising the Period from the Fourteenth to the Seventeenth Century. Medium 8vo.

[Nearly ready.

IREV. HERBERT HAINES.

A MANUAL FOR THE STUDY OF MONUMENTAL BRASSES. With numerous Illustrations, and a List of those remaining in the British Isles. By the Rev. Herbert Haines, M.A. Medium 8vo., price to Subscribers, 12s.

[Nearly ready.

\section{REV. C. H. HARTSHORN E.}

THE MILITARY ARCHITECTURE OF THE MIDDLE AGES, Translated from the French of M. VioLLET-LE-Duc, with Notes on English Castles, by the Rev. C. H. HARTshorNe, M.A., the original French Engravings and English Examples added. Medium 8vo.

[In the press.

\section{A SERIES OF MANUALS.}

A SERIES OF MANUALS OF GOTHIC ORNAMENT. One Shilling Each.

No. 1. Stone Carving.

No. 2. Mouldings.

No. 3. Surface Ornament. 


\section{PROFESSOR STANLEY.}

THREE INTRODUCTORY LECTURES ON THE STUDY OF ECClesiastical History. By Arthur Penrhyn Stanley, M.A., Regius Professor of Ecclesiastical History, and Canon of Christ Church. 8vo., sewed, 2s. 6 d.

REV. L. P. MERCIER.

CONSIDERATIONS RESPECTING A FUTURE STATE. By the Rev. Lewis P. Mercier, M.A., University College, Oxford. Fcap. 8vo., 4s.

\section{REV. J. M. NEALE.}

A HISTORY OF THE SO-CALLED JANSENIST CHURCH of HOLLAND; with a Sketch of its Earlier Annals, and some Account of the Brothers of the Common Life. By the Rev. J. M. NeALE, M.A., Warden of Sackville College. 8 vo., cloth, 10s. 6 d.

\section{REV. E. HAWKINS, D.D.}

A MANUAL FOR CHRISTIANS, designed for their use at any time after Confirmation. By Edward Hawkins, D.D., Provost of Oriel College. Seventh Edition, 12mo., 6d., sewed.

\section{REV. T. T. CARTER.}

LIFE of JOHN ARMSTRONG, D.D., late Lord Bishop of Grahamstown. By the Rev. T. T. CARTER, M.A., Rector of Clewer. With an Introduction, by SAMUel, LoRd Bishop of Oxford. Second Edition. Fcap. 8vo., with Portrait, cloth, 7s. 6d.

THE LATE BISHOP ARMSTRONG.

ESSAYS ON CHURCH PENITENTIARIES. Fcap. 8vo., cloth, price 2 s. $6 \mathrm{~d}$.

\section{ST. AOGUSTINE.}

ST. AUGUSTINE'S EXPOSITIONS ON THE BOOK OF PSALMS, translated with Notes and Indices. Complete in Six Volumes, 8vo., price in cloth, $£ 216$ s. 6 d.

\section{ST. ANSELM.}

MEDITATIONS AND SELECT PRAYERS, by St. ANselm, formerly Archbishop of Canterbury. Edited by E. B. Pusey, D.D. Fcap. 8vo., 5s.

CUR DEUS HOMO, or WHY GOD WAS MADE MAN; by St Anselm. Fcap. 8vo., 2s. 6 d. 
HISTORICAL AND PRACTICAT, SERMONS ON THE SUFFERINGS AND RESURRECTION OF OUR LORD. By a Writer in the Tracts for the Christian Seasons. 2 vols., fcap. 8vo. cloth, 10s.

SERMONS ON NEW TESTAMENT CHARACTERS. By the Author of "Sermons on the Prayer-book," and "On the Sufferings and Resurrection of our Lord." Fcap. 8vo., 4s.

PLAIN SERMONS PREACHED IN PARISH CHURCHES. Br Thomas Barker, M.A., of Queen's College, Oxfor: ; Curate of Broomficld, Essex; late Tutor of Codrington College, Barbados. P'ost 8vo., cloth, 6s. $6 \mathrm{~d}$.

LEAMINGTON COLLEGE SERMONS. - School Life. - Sermons preached in the Chapel of Leamington College. By Thomas Burbinge, LL.D., Master of the College. Fcap. 8vo., cloth, 5s.

ARMSTRONG'S PAROCHIAL SERMONS. Parochial Sermons, by John Armstrong, D.D., late Lord Bishop of Grahamstown. A New Edition. Fcap. 8vo., cloth, 5s.

ARMSTRONG'S SERMONS FOR FASTS AND FESTIVALS. A new Edition. Fcap. 8vo., 5s.

PLAIN SERMONS ON THE BOOK OF COMMON PRAYER. By a Writer in the "Tracts for the Christian Seasons." Fcap. 8vo., cloth, $5 \mathrm{~s}$.

SHORT SERMONS FOR FAMILY READING. Ninety Short Sermons for Family Reading, following the course of the Christian Seasons. By the Author of "A Plain Commentary on the Gospels." 2 volumes, cloth, 8s.

THE CONSTRAINING LOVE OF CHRIST. A Sermon preached at the Ordination in Cuddesdon Church, on Trinity Sunday, 1859. By H. Hutchinson Swinny, M.A., Principal of Cuddesdon Theological College. Together with Three Sermons preached during the preceding Einber-Week. By Jacos Crements, M.A., of Oriel College, Oxford. Published at the desire of the Lurd Bishop of Oxford. Fcap. 8vo., 1s. 6 d.

\section{SINGLE SERMONS.}

Bishop of Oxford.

THE GATHERING OF LONGPARTED CHRISTIAN MEN : a Sermon preached in the Chapel of Exeter College, Oxford, at the Consecration, Oct. 18, 1859. By SAMUFL, LORD BISHOP OF OXFORD, Chancellor of the Most Noble Order of the Garter, and Lord High Almoner to the Queen. 8 vo., price 1s.

Rev. C. J. Vaughan.

THE COMPARATIVE BLESSEDNESS OF RECEIVING AND GIVING: a Sermon preached in St. Mary's Church, Oxford, for the Radcliffe Intirmary, on Tuesdav, July 5, 1859. By Charles JoHN VAUGHAN, D.D., Head Master of Harrow School, Chaplain in Ordinary to the Queen, and late Fellow of Trinity College, Cambridge. Svo., price 1s.

\section{Rev. R. St. John Tyrwhitt.}

HERODIAS. - AGAINST VANITY. Two Sermons preached at St. M 7 ry Magdalen Church, Oxford, by the Rov. R. ST. John TrRwhitT, M.A., Vicar of the Parish; late Student and Rhetoric Reader of ChristChurch. 12mo., pricc6ri.
Rev. W. B. Jones.

THE RESPONSIBILITY OF MAN TO THE LAW OF GOD. A jermon preached in the Church of St. Marytho-Virgin, before Sir James Shaw Willes and Sir John Barnard Byles, two of the Justices of the Court of Common Pleas; and the University of Oxford, at the Millsummer Assize, July 14, 1859. By WILliam Busil. Joses, 14, 15.99. lato Fellow and Tutor of University Collogo. Published at tho request of tho High Sheriff. 8vo., prico is.

\section{Rev. J. W. Burgon.}

ONE SOWETH AND ANOTHER REAPETH. A Sermon presched at Buckingham, on the second Sunday in Lent, March 20, 1859, at the Ordinntion held by the Right Reverend the Lord Bishop of Oxford. Pullished by desiro of the Bishop and the Clergy. To which is prefixed some account of the Special Survices for the Working Classes in North Bucks., during the Lesten E Nor Week. 1859. By the Rev. J. W. IBURgos, M.A.. Fullow of Oriel Collogo. 12mo., price 6il. 
SOME YEARS AFTER: A Tale. Feap. 8vo, cloth lettered, 7s.

THE SCHOLAR AND THE TROOPER; OR, OXFORD DURING THE GREAT REBEllion. By the Rev. W. E. Heygate. Second Edition. Fcap. 8vo., cloth, 5 s.

MIGNONETTE: A SKETCH. By the Author of "The Curate of Holy Cross." 2 vols., fcap., cloth, 10 s.

ATHELINE; or, The Castle by the Sea. Fcap. 8vo. [Nearly ready.

ALICE LISLE : A Tale of Puritan Times. Fcap. 8vo. [In the press.

STORM AND SUNSHINE; OR, THE BOYHOOD OF HERBERT FALCONER. A Tale. By W. E. Dickson, M.A., Author of "Our Workshop," \&c. With Frontispiece, cloth, 2s.

AMY GRANT; or, The One Motive. A Tale designed principally for the Teachers of the Children of the Poor. Second Edition. Fcap. 8vo., cloth, 3s. $6 \mathrm{~d}$.

THE TWO HOMES. A Tale. By the Author of "Amy Grant." Second Edition. Fcap. 8vo., cloth, 2s. 6 d.

DAWN AND TWILIGHT. A Tale. By the Author of "Amy Grant," "Two Homes," \&c. 2 vols. fcap. 8vo., cloth, 7s.

KENNETH; oR, THE REAR-GUARD OF THE GRAND ARMY. By the Author of the "Heir of Redclyffe," "Heartsease," \&c., \&c. Third Edition. Fcap. 8vo., with Illustrations, $5 \mathrm{~s}$.

\section{TALES FOR THE YOUNG MEN AND WOMEN OF ENG-}

LAND. A Series of Tales adapted for Lending Libraries, Book Hawkers, \&c.

Fcap. 8vo., with Ill s trations, strongly bound in coloured wrapper, 1s. each.

No. 1. Mother and Son.

No. 2. The Recruit. A new Edition.

No. 3. The Strike.

No. 4. James Bright, the Shopman.

No. 5. Jonas Clint.

No. 6. The Sisters.

No. 7. Caroline Eiton; or, Vanity and Jealousy. 1 s.

No. 8. Servants' Influence.

No. 9. The Railway Accident.

No. 10. Wanted, a Wife.

No. 11. Irrevocable.
No. 12. The Tenants at Tinkers' End.

No. 13. Windycote Hall.

No. 14. False Honour.

No. 15. Old Jarvis's Will.

No. 16. The Two Cottages.

No. 17. Squitch.

No. 18. The Politician.

No. 19. Two to One.

No. 20. Hobson's Choice. 6d.

No. 21. Susan. 4d.

No. 22. Mary Thomas; or, 4 d.

\footnotetext{
"To make boys learn to read, and then to place no good books within their reach, is to give them an appetite, and leave nothing in the pantry save unwholesume and poisonous food, which, depend upon it, thes will eat rather than starve."- Sir W. Scott.
} 


\section{HISTORICAL TALES, Illustrating the chief events in Ecclesinstical}

History, British and Foreign, adapted for General Reading, Paroclial Libraries, \&c. Nw pub lishing, in Monthly Volumes, with a Frontispice, price 18.

Those who know the Church to be God's appointed instrument for the regeneration of mankind, and, regarding it as such, have tried to impress her clains upon others, in opposition to the sectarianism of the day, are well aware of the difficulty they have to encounter in the almost universal igncrance, even amongst persons supposed to be well educated, of the facts of Ecclesiastical History. This is not surprising, considering how dry and uninteresting to all but the divinity student are most treatises upon this subject. Yet the moment we turn aside from the beaten track that connects one great epoch with another, we find incidents of the most exciting, attractive, and instructive kind, crowding together with a truth more strange than fiction, and wonderfully illustrative of the progress of the faith and of the inner and outer life of the Church. announced will embrace the most important periods and transactions connected with the progress of the Church in ancient and modern times. They will be written by a uthors of acknowledged merit, in a popular style, upon sound Church principles, and with a single eye to the inculcation of a true estiniate of the circumstances to which they relate, and the bearing of those circumstances upon the listory of the Church. By this means it is hoped that many, who now regard Church history with indifference, will be led to the perusal of its singularly interesting and instructive episodes.

The Series is to be conducted by a responsible Editor, and it is intended that, when complete, it shall illustrate not only portions of the history of the Church in Great Britain, but also in her Colonies, in the different countries of Europe, and in the East. The extent of the Series must, of course, greatly depend upon the favour and support accorded to it by the Public.

Each Tale, although forming a link of the entire Series, will be complete in itself, enabling persons to subscribe to portions only, or to purchase any single Tale separately.

Already published.

No. 1.-THE CAVE IN THE HILLS; or, Cæcilius Viriāthus.

No. 2.-THE EXILES OF THE CEBENNA: a Journal written during the Decian Persecution, by Aurelius Gratianus, Priest of the Church of Arles; and now done into English.

No. 3.-THE CHIEF'S DAUGHTER; or, The Settlers in Virginia.

No. 4.-THE LILY OF TIFLIS: a Sketch from Georgian Church History.

No. 5.-WILD SCENES AMONGST THE CELTS.

No. 6. -THE LAZAR-HOUSE OF LEROS : a Tale of the Eastern Church in the Seventeenth Century.

No. 7.-THE RIVALS : a Tale of the Anglo-Saxon Church.

No. 8.-THE CONVERT OF MASSACHUSETTS.

No. 9.-THE QUAY OF THE DIOSCURI : a Tale of Nicene Times. 


\section{REV. P. FREEMAI.}

THE HOLY EUCHARIST considered as a MYSTERY: being the Introduction to Part II. of THE PRINCIPLES OF DIVINE SERVICE. By the Rev. Philip Freeman, M.A. 8vo., cloth, 6s.

This treatise is eomplete in itself, and may be had separately. It is of about the compass of Bishop Bethell's work on Baptismal Regeneration, and is designed to serve as a similar manual on the doetrine of the Eucharist.

\section{By the same Author.}

THE PRINCIPLES OF DIVINE SERVICE. An Inquiry concerning the true manner of understanding and using the order for Morning and Evening Prayer, and for the Administration of the Holy Communion in the English Church. 8vo., cloth, 10s. 6d.

\section{THE BOOX OF PSALISS.}

\section{A PLAIN COMMENTARY ON THE BOOK OF PSALMS,} (Prayer-book Version,) chiefly grounded on the Fathers; for the use of Families. 2 vols. fcap. 8 vo., cloth, 10 s. 6 d.

\section{REV. J. DAVISON.}

DISCOURSES ON PROPHECY, in which are considered its Structure, Use, and Inspiration: being the substance of Twelve Sermons preached in the Chapel of Lincoln's Inn, by Jonn Davison, B.D. Sixth and cheaper Edition. 8vo., cloth, 9 s.

REV. J. S. BARTLETT.

A BRIEF HISTORY OF THE CHRISTIAN CHURCH, from the First Century to the Reformation. By Rev. J. S. Barteetr. Fcap. 8vo., cloth, 2s. 6 d.

\section{MRS. HAMILTON GRAY.}

THE EMPIRE AND THE CHURCH, from Constantine to Charlemagne. By Mrs. Hamilton Grax. Crown 8vo., cloth, 12s.

REV. C. E. KENNAWAY.

PERDITA AND ANGELINA; OR, THE LOST ONE FOUND. An Anglo-Roman Dialogue. By the Rev. C. E. Kexnaway. Together with Romeward and Homeward. Fcap. 8vo., cloth, 3s. 6d. Pt. II., separately, 1s.

\section{REV. ARTHUR WOODGATE.}

ANOMALIES IN THE ENGLISII CHURCH no just grounds for Seceding; or, The Abnormal Condition of the Church considered with reference to the Analogy of Scripture and of IHistory. By IIEnry Artilur Woodgate, 13.D. Feap. Svo., chuth, 2s. 6 d. 


\section{THE IATE BISHOP ARMSTRONG.}

THE.PASTOR IN HIS.CLOSET; or, A Help to the Devotions of the Clergy. By John Armstrona, D.D., late Lord Bishop of Grahamstown. Second Edition. Feap. 8vo., cloth, 2s.

\section{REV. E. MONRO.}

DAILY STUDIES DURING ILENT. By the Rev. Enwarn Movro, Incumbent of Harrow Weald, Middlesex; Author of "Parochial Work," "The Parish," "The Combatants," \&c. Fcap. 8vo., antique cloth, 6s.

\section{REV. G. ARDEN.}

BREVIATES FROM HOLY SCRIPTURE, arranged for use by the Bed of Sickness. By the Rev. G. Arden, M.A., Rector of Winterborne-Came; Domestic Chaplain to the Right Hon. the Earl of Devon; Author of "A Manual of Catechetical Instruction." Fcap. 8vo., 2s. 6 d.

THE CURE OF SOULS. By the Rev. G. Arden, M.A. Feap. 8vo. New Edition in the press.

\section{OXFORD SERIES OF DEVOTIONAL WORKS.}

THE IMITATION OF CHRIST.

\section{FOUR BOOKS. By Thomas a KeM-} PIs. A new Edition, revised, handsomely printed on tinted paper in feap. $8 \mathrm{vo}$., with Yignettes and red borders, cl., 5s.; antique calf, red edges, $10 \mathrm{s.} 6 \mathrm{~d}$.

\section{LAUD'S DEVOTIONS.}

THE PRIVATE DEVOTIONS of Dr. William Laud, Archbishop of Canterbury, and Martyr. A new and revised Edition, with Translations to the Latin Prayers, handsomely printed with Vignettes and red lines. Fcap. 8 vo., antique cloth, $5 \mathrm{~s}$.

\section{WILSON'S SACRA PRIVATA.}

THE PRIVATE MEDITA'TIONS, DEVO'IIONS, and PRAYERS of the Right Rev. T. WILson, D.D., Lord Bishop of Sodor and Man. Now first printed entire. From the Original Manuscripts. Feap. 8vo., 6s.

\section{ANDREWES' OEVOTIONS.}

DEvotions. By the Right Rev. Father in God, LAuncelot ANDREwes, Translated from the Greek and Latin, and arranged anew. Fcap. 8 vo., 5s.; morocco, 8s.; antique calf, red edges, 10s. 6 d.
SPINCKES' DEVOTIONS.

\section{TRUE CHURCH OF ENGLAND} MAN'S COMPANION IN THE CLOSET; or, a complete Manual of Private Devotions, collected from the Writings of eminent Divines of the Cliurch of England. Sixteenth Edtion, corrected. Fcap.8vo., floriated borders, cloth, antique, $4 s$.

The above set of 5 Volumes, in neat grained calf binding, $t^{2} 2 x$.

\section{TAYLOR'S HOLY LIVING.}

THE RULE AND EXERCISES OF HOLY LIVING. By BisHOP JEREMY TAYLor. In which are described the means and instruments of obtaining every virtue, and the remedies against every vice. In antique cloth binaing, $4 s$.

\section{TAYLOR'S HOLY DYING.}

THE RULE AND EXERCISES OF HOLY DYING. By BISHOP JEREMY TAYLor. In which are described the mcans and instruments of preparing ourselves and others respectively for a blessed death, \&c. In antique cloth binding, $4 s$. 


\section{THE AUTHOR OF "THE CHRISTIAN YEAR."}

THE CHRISTIAN YEAR. Thoughts in verse for the Sundays and Holydays throughout the Year. Imperial Octavo, with Illuminated Titles,-Cloth, 1l. 5s.; morocco, 1l. 11s. 6d.; best morocco, 2l. 2s. Octavo Edition,_Large type, cloth, 10s. 6d.; morocco by Hayday, 21s.; antique calf, 18s. Foolscap Octavo Edition,-Cloth, 7s. 6d.; morocco, 10s. 6 d. ; morocco by Hayday, $15 \mathrm{~s}$.; antique calf, 12s. 32mo. Edition,-Cloth, 3s. 6 d. ; morocco, plain, 5s.; morocco by Hayday, 7s. Cheap Edition,_Cloth, 1s. 6 d. ; bound, $2 \mathrm{~s}$.

LYRA INNOCENTIUM. Thoughts in Verse for Christian Children. Foolscap Octavo Edition,-Cloth, 7s. 6d. ; morocco, plain, 10s. 6d.; morocco by Hayday, 15s.; antique calf, 12s. 18mo. Edition,-Cloth, 6s.; morocco, 8s. 6d. 32mo. Edition,-Cloth, 3s. 6d.; morocco, plain, 5s.; morocco by Hayday, 7s. Cheap Edition,-Cloth, 1s. 6d.; bound, 2s.

\section{THE AUTHOR OF "THE CATHEDRAL."}

THE CATHEDRAL. Foolscap 8vo., cloth, 7s. 6d.; 32mo., with Engravings, 4s. 6 d.

THOUGH'TS IN PAST YEARS. The Sixth Edition, with several new Poems, 32mo., cloth, 4s. 6d.

THE BAPTISTERY; or, The Way of Eternal Life. 32mo., cloth, 3s. $6 \mathrm{~d}$.

The above Three Volumes uniform, 32 mo, neatly bound in morocco, $18 \mathrm{~s}$.

THE CHRISTIAN SCHOLAR. Foolscap 8vo., 10s. 6d.; 32mo., cloth, 4s. $6 \mathrm{~d}$.

THE SEVEN DAYS; or, The Old and New Creation. Second Edition, foolscap 8vo., 7s. 6 d.

MORNING Thoughts. By a Cиergyman. Suggested by the Second Lessons for the Daily Morning Service throughout the year. 2 vols. foolscap 8 vo., cluth, 5s. each.

THE CHILD'S CHRISTIAN YEAR. Hymns for every Sunday and Holyday throughout the year. Cheap Edition, 18mo., cloth, 1s.

COXE'S CHRISTIAN BALLADS. Foolscap 8vo., cloth, 3s. Also selected Poems in a packet, sewed, 1 s.

FLORUM SACRA. By, the Rev. G. Hunt Smytray. Second Edition, 16mo., $1 \mathrm{s.}$ 
CATECHETICAL WORKS, Designed to aid the Clergy in Public Catechising. Uniform in size and type with the "Parochial Tracts."

Recently published in the Series.

V. Catechetical Lessons on the Parables of the New Testament. Part I. Parables I.-XXI. 1s.

VI. Part II. Parables XXII. -XXXVII. 18.

VII. Catechetical Notes on the Thirty-Nine Articles. 1s. $6 \mathrm{~d}$.

VIII. Catechetical Lessons on the Order for Morning and Evening Prayer, and the Litany. 1s.

IX. Catechetical Lessons on the Miracles of our Lord. Part I. Miracles I-XVII. 1s.

X. Part II. Miracles XVIII. -XXXVII. 1s.

XI. Catechetical Notes on the Saints' Days. 1s.
Already published in this Series.

I. Catechetical Lessons on the Creed. 6d.

II. Catechetical Lessons on the Lord's Prayer. 6d.

III. Catecheticat Lessons on the Ten Commandments. $6 \mathrm{~d}$.

IV. Catechetical Lessons on the Sacraments. $6 \mathrm{~d}$.

Questions on the Coluects, Epistles, and Gospels, throughout the Year; edited by the Rev. T. L. Claughton, Vicar of Kidderminster. For the use of Teachers in SundaySchools. Two Parts, 18 mo., cloth, each 2s. 6 d.

COTTAGE PICTURES. Cottage Pictures from the Old Testament. Twenty-eight large Illustrations, coloured by hand. The set, folio, $7 \mathrm{~s} .6 \mathrm{~d}$.

COTTAGE PICTURES from the New Testament, (uniform with above). The set of $28,7 \mathrm{~s} .6 \mathrm{~d}$.

SCRIPTURE PRINTS FOR PAROCHIAL USE. Printed in Sepia, with Ornamental Borders. Price One Penny each; or the set in an ornamental envelope, One Shilling.

1. The Nativity.

2. St. Jolnn Preaching.

3. The Baptism of Christ.

4. Jacob's Dream.

5. The Transfiguration.

6. The Good Shepherd.

7. The Tribute-Money.

8. The Preparation for the Cross.

9. The Crucifixion.

10. Leading to Crucifixion.

11. Healing the Sick.

12. The Return of the Prodigal.

Ninety thousand have already been sold of these prints. They are also kept mounted and varnished, 3d. each.

PARKER'S CHURCH CALENDAR AND GENERAL ALMANACK, published Annually, contains, besides the usual information of an Almanack, much that is contained in no other, particularly with regard to the state and progress of the Church in America and the Colonies. 12mo. 6d.

The Church, with information regarding the several Dioceses of England, Scotland, and Ireland, the Colonies and America.

The Universities, with other Educational Institutions, Theological Colleges, Schools, \&c.

The State. The Members of the Royal Family, Houses of Parliament, \&c., \&c.

Mrscellaneous. The Kings and Queens of England, Statistics of the Population, Post Office, \&c., \&c. 
ANNALS OF ENGLAND. An Epitome of English History. From Cotemporary Writers, the Rolls of Parliament, and other Public Records. 3 vols. fcap. 8vo., with Illustrations, cloth, 15s. Recommended by the Examiners in the School of Modern History at Oxford.

"The book strikes us as being most useful as a Handbook for teachers. It is just the sort of help for a tutor to have lying by him as a guide to his lecture. The main facts he will find marshalled in strict chronological order, and he will be assisted by references to the statutebook and the old chronicles. The 'ANNALs' will, in short, supply the dry bones of an historical lecture, which each teacher must clothe for himself with life and spirit. Bnt the work will also be highly useful to stadents, especially for the purpose of refreshing the memory and getting details into order, after the perusal of more regular narratives. We trust to see it extensively employed in the Universities. At Oxford it may be especially serviceable. A reliable guide to the original authorities, and one which gives its proper prominence to the early listory, may, if it falls into the hands of either students or teachers, do something to dispel the illusion that English history can be profitably studied by beginning at the momentary overthrow of English nationality, and that, after all the lahours of Turner, Lingard, Palgrave, Kemble. Lnppenherg, and Panli, David Humestill remains the one correct, orthodox, and nnupproachable text-book for its study."-Saturday Revieve.

THE E'THICS OF ARISTOTLE. With Notes by the Rev. W. E. JELF, B.D., Author of "A Greek Grammar," \&c. 8vo., cloth, 12s.

The Text separately, $5 \mathrm{~s}$. The Notes separately, $7 \mathrm{~s} .6 \mathrm{~d}$.

CICERO'S TUSCULAN DISPUTATIONS. M. Tullii Ciceronis Tusculanarum Disputationum. Libri quinque. 16mo., cloth, 2s. (Oxford Pocket Classics.)

THE ILIAD OF HOMIER. First Six Books. 16mo,, cloth, 2s. (Oxford Pocket Classics.)

\section{XENOPHONTIS DE CYRI EXPEDITIONE LIBRI SEPTEM.} 2s. (Oxford Pocket Classics.)

MADVIG'S LATIN GRAMMAR. A Latin" Grammar for the Use of Schools. By Professor MADvig, with additions by the Author. Translated by the Rev. G. F. Woons, M.A. Uniform with JELF's "Greek Grammar." Fourth Edition, with an Index of Authors, 8vo., cloth, $12 s$.

Competent authorities pronounce this work to be the very best Latin Grammar yet published in England. This new Edition contains an Index to the Authors quoted.

JELF'S GREEK GRAMMAR.-A Grammar of the Greek Language, chiefly from the text of Raphael Kühner. By WM. EDW. JELF, M.A., Student of Ch. Ch. 2 vols. 8vo. Second Edition. 1l. 10s.

This Grammar is now in general use at Oxford, Cambridge, Dublin, and Durham; at Eton, King's College, London, and other public schools.

A MANUAL OF GREEK AND LATIN PROSE COMPOSITION, specially designed to illustrate the differences of Idiom between those Languages and the English. By E. R. Hum PIIREys, LL.D., late Head Master of Cheltenlam Grammar-school. Crown 8vo., cloth, 3s. 6d. LAWS OF THE GREEK ACCENTS. By John GRIFriths, M.A.
16mo. Fifth Edition. Price Sixpence.

EXAMINATION PAPERS, AND DIVISION LISTS, \&c., FOR the Examination held in June, 1859, under the Statute "De Examinatione Candidatorum qui non sunt de Corpore Universitatis." Just published. 8vo., 3s. 6d. 
A NEIV SERIES of the Greek and Latin Classics for the use of Schools.

"Mr. Parker is supplying a want long felt, in issuing a series of good classical texts, well edited, and in a cheap form. The expensiveness of our school-books is a crying evil, which cannot be too soon abated. It is absurd extravagance to put costly books into the hands of schoolboys, to be thumbed and torn to pieces, when cheaper ones would answer every useful purpose just as well. In this respect our neighbours on the Continent are far more rational than we are. We look with satisfaction upon Mr. Parker's efforts to bring about an amendment. Though we think it would have been better to announce the editor's name, we willingly bear testimony to the ability with which he has executed his task, and have much pleasure in recommending the Texts as suitable for school purposes."-Athenaum.

\section{GREEK POETS.}

s. $d$. Paper. Bound.

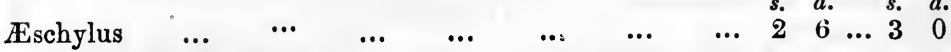

$\begin{array}{llllllllllll}\text { Aristophanes. } 2 \text { vols. } & \ldots & \ldots & \ldots & \ldots & \ldots & 5 & 0 & \ldots & 6 & 0\end{array}$

$\begin{array}{lllllllllllll}\text { Euripides. } & 3 \text { vols. } & \ldots & \ldots & \ldots & \ldots & \ldots & \ldots & 5 & 0 & \ldots & 6 & 6\end{array}$

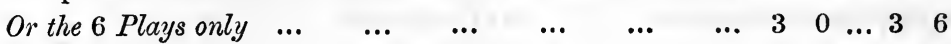

$\begin{array}{lllllllllllll}\text { Sophocles } & \ldots & \ldots & \ldots & \ldots & \ldots & \ldots & \ldots & 2 & 6 & \ldots & 3 & 0\end{array}$

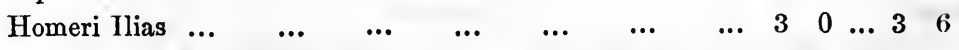

$\begin{array}{llllllllllll}\text { Odyssea } & \ldots & \ldots & \ldots & \ldots & \ldots & \ldots & 2 & 6 & \ldots & 3 & 0\end{array}$

GREEK PROSE WRITERS.

$\begin{array}{llllllllllll}\text { Aristotelis Ethica } & \ldots & \ldots & \ldots & \ldots & \ldots & \ldots & 1 & 6 & \ldots & 2 & 0\end{array}$

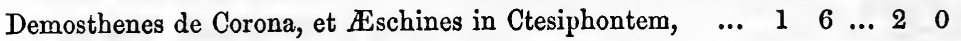

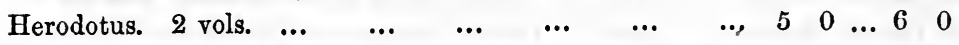

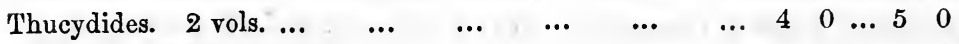

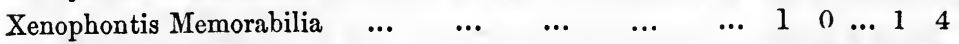

Anabasis

\section{LATIN POETS.}

$\begin{array}{lcccccccccccc}\text { Horatius } & \ldots & \ldots & \ldots & \ldots & \ldots & \ldots & \ldots & 1 & 6 & \ldots & 2 & 0 \\ \text { Juvenalis et } & \text { Persius } & \ldots & \ldots & \ldots & \ldots & \ldots & \ldots & 1 & 0 & \ldots & 1 & 6 \\ \text { Lucanus } & \ldots & \ldots & \ldots & \ldots & \ldots & \ldots & \ldots & 2 & 0 & \ldots & 2 & 6 \\ \text { Lucretius } & \ldots & \ldots & \ldots & \ldots & \ldots & \ldots & \ldots & 1 & 6 & \ldots & 2 & 0 \\ \text { Phædrus } & \ldots & \ldots & \ldots & \ldots & \ldots & \ldots & \ldots & 1 & 0 & \ldots & 1 & 4 \\ \text { Virgilius } & \ldots & \ldots & \ldots & \ldots & \ldots & \ldots & \ldots & 2 & 0 & \ldots & 2 & 6\end{array}$

\section{LATIN PROSE WRITERS.}

$\begin{array}{llllllll}\text { Cæsar } & \ldots & \ldots & \ldots & \ldots & \ldots & \ldots & \end{array}$

$\begin{array}{llllll}\ldots & 2 & 0 & \ldots & 2 & 6\end{array}$

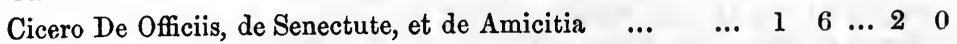

Ciceronis Tusculanarum Disputationum Libri V. $\ldots \begin{array}{lllllll} & \ldots & 1 & 6 & \ldots & 2 & 0\end{array}$

Cornelius Nepos

Livius. 4 vols.

Sallustius

Tacitus. 2 rols. 
THE PLAYS OF SOPHOCLES, with English Notes by Members of the University of Oxford. Col.uplete in 2 vols., cloth, 6s., or separately-

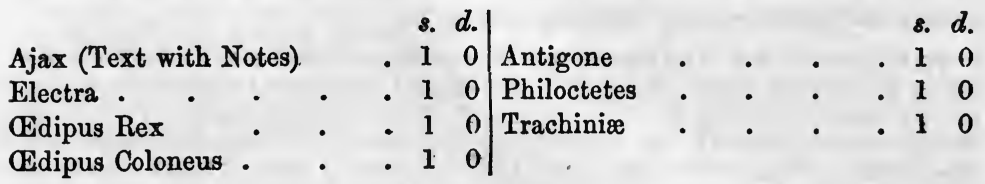

THE PLAYS OF ASCHYLUS, with English Notes by Members of the University of Oxford. Complete in 2 vols., cloth, 7s. $6 \mathrm{~d}$.

Prometheus Vinctus '(Text with Notes)

Septem Contra Thebas .

Persæ

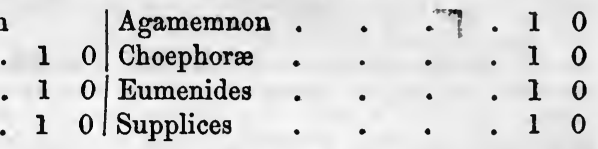

THE PLAYS OF EURIPIDES, with English Notes by Members of the University of Oxford. Complete in 2 vols., cloth, 6s. $6 \mathrm{~d}$.

Hecuba (Text with Notes) . 10 Hippolytus . . . . 10

Medea . . . . . 10 Phœnissæ . . . . 10

Orestes . . . . 10 Alcestis . . . . 10

"The notes contain sufficient information, / years ago, we had put into our hands a portly without affording the pupil so much assistance 8vo. volume, containing Porson's four plays, as to supersede all exertion on his part." - without one word of English in the shape of Atheneum, Jan. 27, 1855.

"Be all this as it may, it is a real benefit to notes; and we have no doubt the book cost public schoolboys to be able to purchase any was nothing near so useful as these neat little Greek Play they want for One Shilling. When copies at One Shilling each." - Educational we were introduced to Greek plays, about forty $\mid$ Times.

The Text of SopнocLes separately. One vol., cloth, $3 \mathrm{~s}$. - The Notes, ditto, 3s. The Text of Eschyuus separately. One vol., cloth, 3s.-The Notes, ditto, 3s. 6d. The Text of Euripides separately. One vol., cloth, 3s. 6d.-The Notes, ditto, 3s.

Pocket Editions of the following have also been published with

Short Notes.

DEMOSTHENES.

De Corona . . . . $20 \mid$ Eschines in Ctesiphontem 20 VIRGIL.

The Bucolics . . . . 1 0| The Georgics . . . . 20 The First Three Books of the ENEID, 1 s.

HORACE.

Odes and Etodes . . . 2 0| Satires . . . . . 10

Epistles and Ars Poetica, 1 s.

The Text in one vol., cloth, $2 \mathrm{~s}$.

The Notes in one vol., cloth, $2 \mathrm{~s}$.

CORNELIUS NEPOS (with Short Notes) • • . 16

PHEDRUS (with Short Notes) . . . . . . 10

HOMER-First SIx Books of ILIAD (with Short Notes) . 20

SALLUST .

Jugurtha $\quad$ - . . $16 /$ Catiline $\quad$. . . 10

In the Press.

Short Notes to Livy, Cicero, and Cessar. 
THE LITERARY CHURCHMAN. A Journal deroted to the interest and advancement of Religious Literature.

THE LITERARY CHURCHMAN was established in order to extend to RELIgious Literature the advantages which General Literature already possessed in the Athenaum, Literary Gazette, Critic, and other similar journals. Previously, Religious Literature had been dependent for publicity on a few scattered notices in Newspapers or Religious Magazines; while the weekly issue of some twenty or thirty works, bearing more or less on Religious subjects, proved an importance sufficient to demand a journal distinctly set apart for the interests of that class of publications.

It is intended by this Journal to place the subscriber entirely au courant with what is being published, by reviewing and noticing all religious works, of whatever class or kind, as they are issued from the press. To many, whose duties render it almost necessary for them to be acquainted with the books or Tracts which are constantly issued, calculated to assist them in their labours, and who, residing perhaps at a distance from any town, or without access to any good Bookseller's shop, see at most but one Church Periodical, this Journal supplies a great desideratum.

The usual contents of the Journal are as follows:-

A Summary of Church Events, and short Articles on the Religious Topics of the day.

Reviews AND Notices of all the new Religious Publications,-as far as possible explaining their nature and object, with criticism, \&c., when needed.

Foreign Books, with lists of all new Religious Works as published in France, Germany, and America.

A Complete List of English Books in General Literature published during the fortuight, arranged according to subjects, with size, price, \&c.

Index, with prices of books noticed,-Literary Notes and Queries, \&c., \&c.

\section{SUBSCRIPTIONS.}

\begin{tabular}{|c|c|c|c|c|c|}
\hline For the Year & $\bullet$ & & • & • & - 8s. 0d. \\
\hline Ditto Free by post & & - & . & • & \\
\hline For Six Months & - & - & - & - & \\
\hline Ditto Free by post & - & . & . & . & 5s. 0d. \\
\hline
\end{tabular}

Orders will be received by most Booksellers and Newsmen throughout the Country, or at the Office, 377 , Strand.

\section{THE PENNY POST. A Church of England Illustrated Magazine,}

\section{issued Monthly. Price One Penny.}

That this Magazine is wanted, a circulation of 22,000 copies of each number testifies. It is the only Penny Magazine upholding sound Church principles. That it does good, and is appreciated, testimony whence it would be least expected, abulldantly proves. But at the same time it must be borne in mind, that this is a small circulation for a Penny religious periodical. Those who differ depend much upon their periodicals for inculcating doctrine hostile to the Church, and circulate thousands, where the Church of England, unfortunately, circulates only hundreds.

MONTHLY.-ONE PENNY.

Subscribers' names received by all Booksellers and Newsmen.

Vols. I., II., III., and IV. of the Old Series, crown $8 \mathrm{vo}$., clotl, may be obtained, price 1s. 6 d. each.

Vols. I., II., III., and IV., of the New Series of the "Penny Pust," 8vo., in handsome wrapper, 1s.; or in cloth, 1 s. 8 d. each. 
WITH the present year of our Lord, 1859, Sylvanus Urban closes his 207th volume, and the 128th year of his literary existence. This is a length of days that, so far as he knows, has never before been attained by a Journalist; but he ventures to affirm, with thankfulness as well as some degree of self-complacency, that he is still in a green old age, and that to his thinking the time is yet very distant when, to borrow the words of one of his earliest and most valued friends, it may be said of him-" Superfluous lags the veteran on the stage."

The times, it is readily allowed, have greatly changed since Sylvanus Urban first solicited public attention, but it may be fairly doubted whether the tastes and habits of thought of the educated classes to whom he addresses himself have changed in a like degree. Hence he does not fear that History and Antiquities, in their widest sense, can ever become unpalatable to them, but, on the contrary, he is glad to mark an increased avidity in pursuing such studies. This is a state of things that he thinks he may claim a considerable share in bringing about, and the steady progress of which he is desirous of forwarding by all available means. He alludes to the growing appreciation of the Past, as the key to the understanding of the Present, and (in a sense) of the Future, as testified by the formation of Archæological and Literary Societies, which have already achieved much good, and may do still more; and as a means to that end, he will, in the coming year, devote a portion of his pages, under the title of "ANTIQUARIAN AND LITERARY INTELLIGENCER," to a record of their progress.

Sylvanus Urban therefore ventures to suggest to the Councils of such Societies, that if brief reports of their proceedings and publications are systematically supplied to the Gentueman's MaGazine, where they will be always highly acceptable, an interchange of knowledge and good offices may thus be established between learned bodies in the most distant parts of the Empire-an interchange that does not now exist, but the want of which few will be found to deny.

It has ever been the desire of Sylvanus Urban to see his CorresponDENCE a leading feature in his pages, and he has had the gratification of reckoning many of the most erudite men of the time as his fellow-workers, who have, through him, conveyed an invaluable amount of knowledge to the world. He invites those of the present day to imitate them. Another important feature has been, and will be, the OBITUary, to the completeness of which he requests friends or relatives to contribute by communicating fitting notices of eminent persons daily removed by the hand of death from among us. He believes that he shall not be disappointed in the extent of this friendly co.operation, but, on the contrary, that the increasing number of his contributors may render the motto that he has so long borne more than ever applicable :- "E pluribus Unum."

All Communications to be addressed to $M_{R}$. URBAN , 377, STRAND, W.C. 


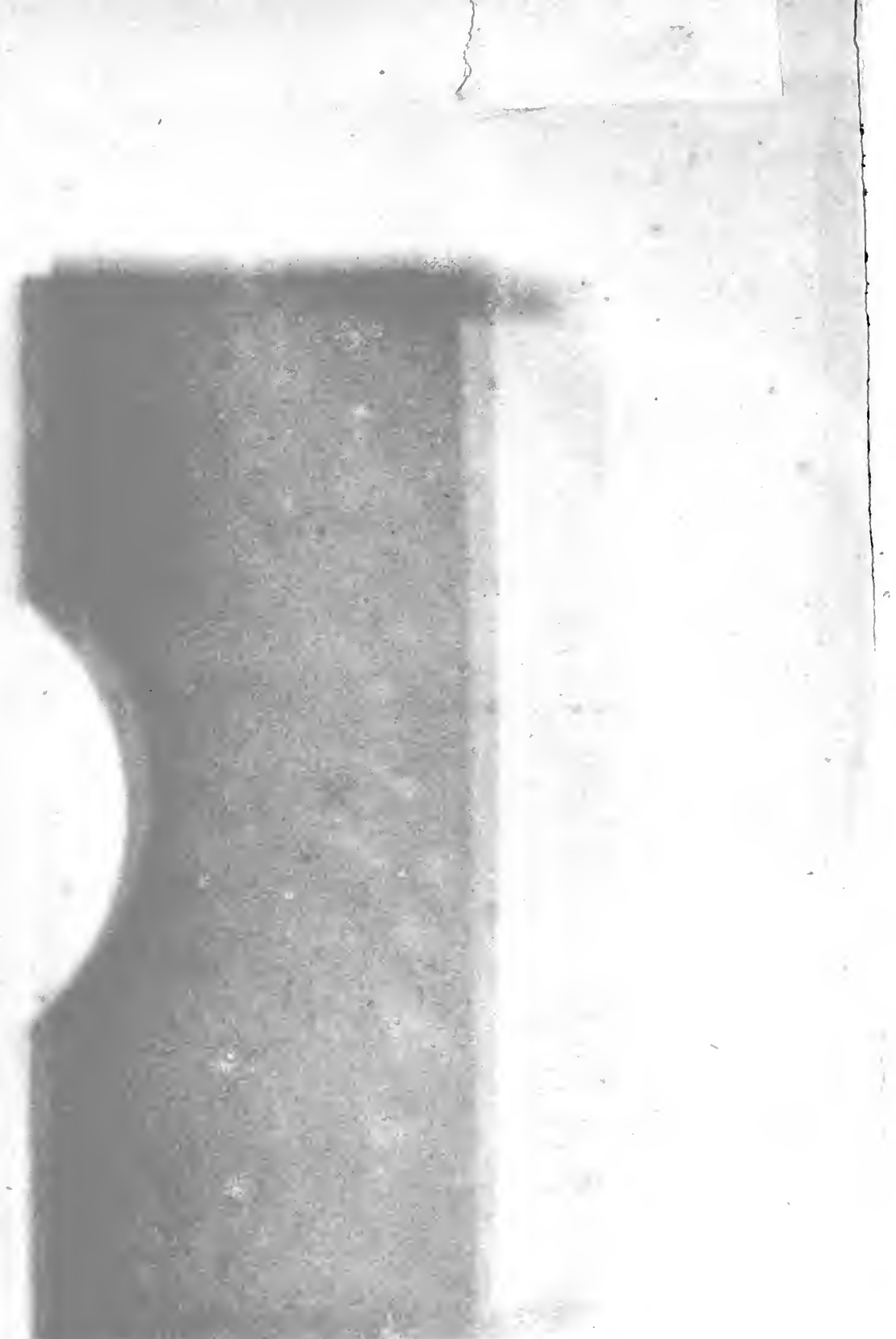


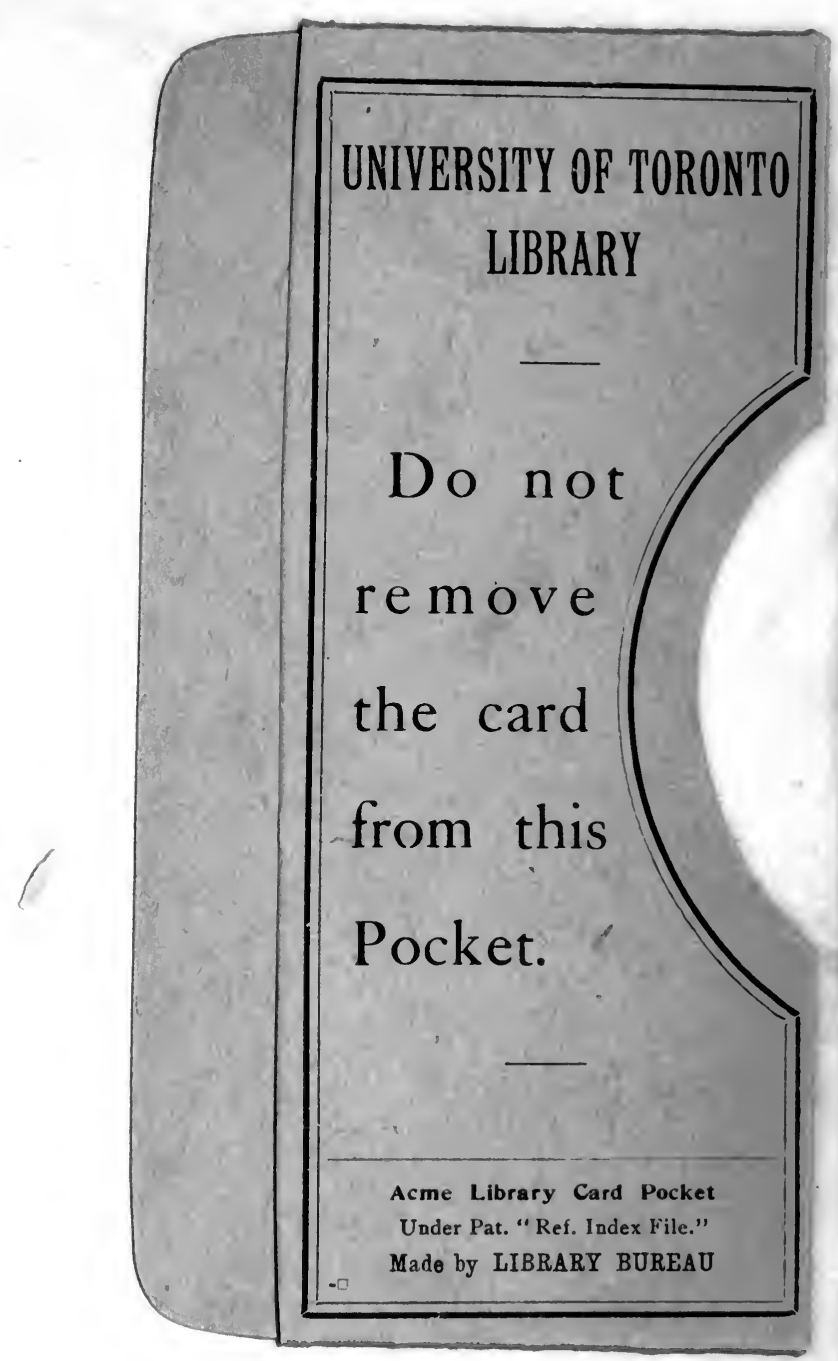


